RODRIGO DE GRANDIS

\title{
A IMPUTAÇÃO NAS ORGANIZAÇÕES EMPRESARIAIS
}

\author{
DisSERTAÇÃo DE MESTRAdO
}

Orientador: Professor Titular Vicente Greco Filho

FACULDADE DE DIREITO DA UNIVERSIDADE DE SÃO PAULO SÃO PAULO

2014 


\section{RODRIGO DE GRANDIS}

\section{A IMPUTAÇÃO NAS ORGANIZAÇÕES EMPRESARIAIS}

Dissertação de Mestrado apresentada à Banca Examinadora, no âmbito do Programa de PósGraduação da Faculdade de Direito da Universidade de São Paulo, como exigência parcial para a obtenção do título de Mestre em Direito, sob orientação do Professor Titular Vicente Greco Filho.

FACULDADE DE DIREITO DA UNIVERSIDADE DE SÃO PAULO SÃO PAULO 
Banca Examinadora 
Ao Professor Vicente Greco Filho, Jurista na legítima acepção do termo, pela imprescindível orientação;

Ao amigo João Daniel Rassi, pelo constante incentivo nestas e em outras terras;

À Carolina Mansur da Cunha Pedro, porque sem ela nada, absolutamente nada seria possível! 


\section{RESUMO}

A presente dissertação propõe-se à análise das diversas categorias de imputação penal no âmbito das organizações empresariais complexas em razão dos fatos cometidos pelas pessoas físicas intervenientes. Para tanto, são expostas as modalidades doutrinárias através das quais pode ser atribuída a responsabilidade penal às pessoas físicas que cometem uma conduta delituosa no âmbito da organização empresarial, independentemente do patamar ocupado. Elaborou-se, ainda, análise diferenciadora entre o fenômeno das organizações empresariais e outras manifestações coletivas, como as organizações criminosas, para a verificação dos critérios mais adequados de imputação penal. Assim, procedeu-se ao estudo da condição jurídica do empresário como responsável penal dos crimes cometidos no âmbito da empresa por ele comandada, em especial sob o enfoque da eventual existência do dever de garante.

Palavras-chave: Imputação penal - organizações empresariais - aparatos organizados de poder - organizações criminosas - responsabilidade por omissão. 


\section{RIASSUNTO}

La presente Tesis si occupa d'analizzare le diverse categorie d'imputazione penale all'interno delle organizzazioni aziendali complesse, per quanto riguarda agli atti commessi attraverso terza persona. Perciò, sono esposti i modi dottrinali per i quali possono essere attribuiti la responsabilità penale alle persone fisiche che commettono una condotta criminale all'interno dell'organizzazione aziendale, indipendentemente del livello che occupano all'interno della azienda. È stata elaborata ancora un'analisi che distingue tra il fenomeno dell'organizzazione aziendale e di altre manifestazioni collettive, come le organizzazioni criminali, per verificare i criteri più appropriati per l'imputazione penale. Cosi, si è proceduto a studiare la posizione giuridica dell'imprenditore per quanto riguarda la responsabilità penale dei reati commessi all'interno della società da una persona che è stata comandata da lui, in particolare dal punto di vista della possibile esistenza del dovere di garantire

Parole chiave: attribuzione penale - delle organizzazioni imprenditoriali - Apparecchi organizzata del potere - criminalità organizzata - di responsabilità per omissione - criminalità organizzata - di responsabilità per omissione. 


\section{SUMÁRIO}

\section{INTRODUÇÃO}

1.1. Abordagem do tema: justificativa para a escolha e a importância da investigação ...................9

1.2. Casos de referência: alguns pontos de partida........................................................................... 12

\section{IMPUTAÇÃO PENAL}

2.1. Introdução: o que significa imputar uma conduta criminosa a alguém?

2.1.1. Três conclusões preliminares

2.2. Imputação penal e nexo de causalidade: insuficiência dos critérios tradicionais.

2.3. Espécies de imputação penal

2.3.1. Imputação objetiva e imputação subjetiva 32

2.3.2. Imputação individual e imputação coletiva .........................................................................33

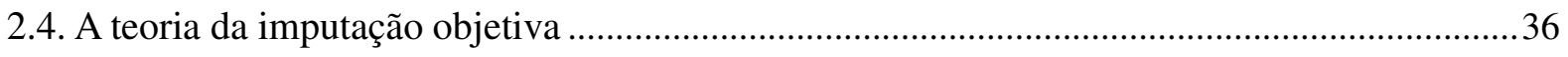

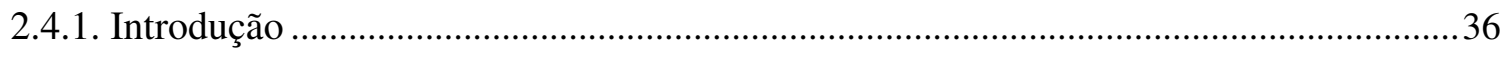

2.4.2. A teoria da imputação objetiva segundo Claus Roxin....................................................... 37

2.4.3. A teoria da imputação objetiva segundo Günther Jakobs ...............................................40

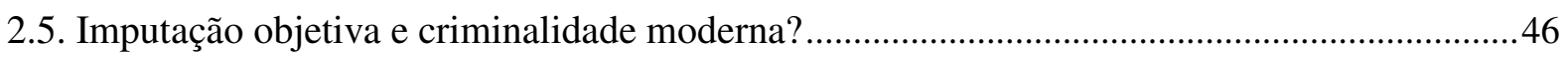

3. ATIVIDADE EMPRESARIAL E DIREITO PENAL …..................................................50

3.1. A conformação da organização empresarial para a imputação ……………………………......50

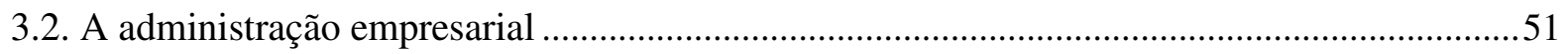

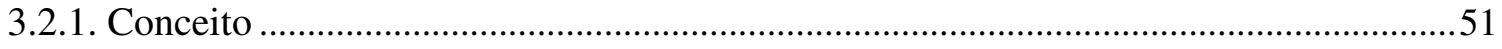

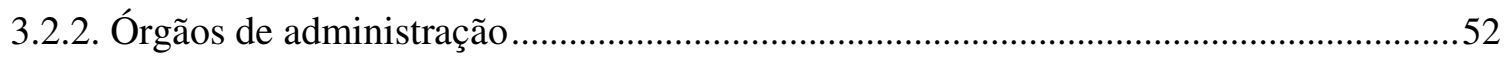

3.2.2.1. Introdução: o administrador da sociedade empresária......................................52

3.2.2.2. Órgãos de administração nas sociedades anônimas...........................................53

3.2.2.2.1. O Conselho de Administração............................................................53

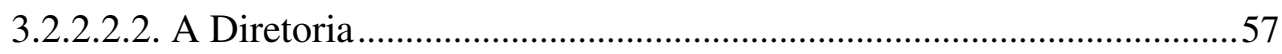

3.2.3. Deveres dos administradores nas sociedades anônimas ...................................................60

3.2.4. Responsabilidade civil dos administradores nas sociedades anônimas ...........................62

\section{MODELOS DE IMPUTAÇÃO PENAL NAS ORGANIZAÇÕES}

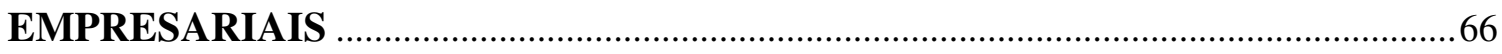

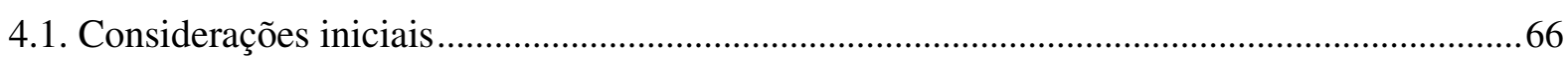

4.2. Imputação penal em razão de condutas comissivas ..............................................................69 
4.2.1. Autoria imediata no âmbito da organização empresarial.................................................71

4.2.2. Autoria mediata no âmbito da organização empresarial ..................................................73

4.2.3. Coautoria no âmbito da organização empresarial ............................................................ 76

4.2.4. A imputação da autoria nos crimes comissivos especiais............................................... 78

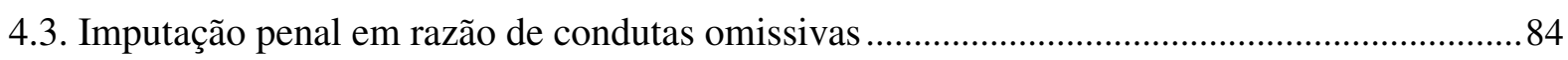

4.3.1. Crimes comissivos por omissão ou omissivos impróprios ............................................... 84

4.3.2. A infração do dever de vigilância na sociedade empresária ............................................... 89

5. CRIMINALIDADE EMPRESARIAL E ORGANIZAÇÕES CRIMINOSAS ...................90

5.1. Introdução: globalização, organização e crime ……………………………………….............90

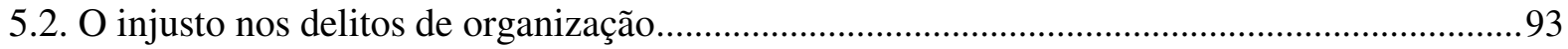

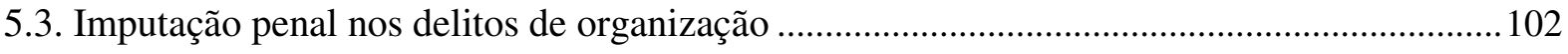

5.4. Quadrilha, associação criminosa e organizações criminosas .................................................. 109

5.4.1. Quadrilha ou bando e as associações criminosas ...........................................................109

5.4.2. Organização criminosa: conceito e elementos identificadores ........................................ 111

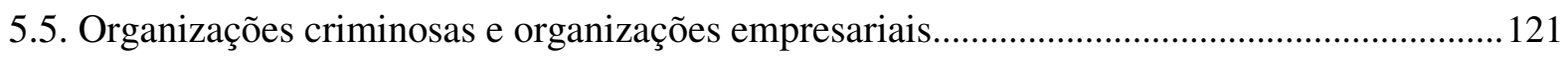

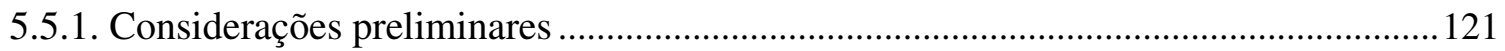

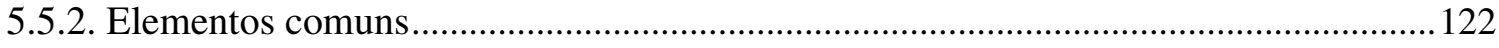

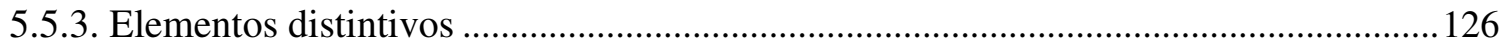

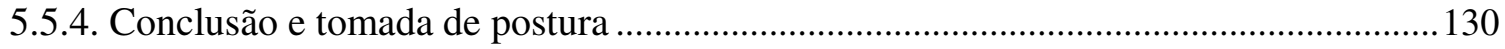

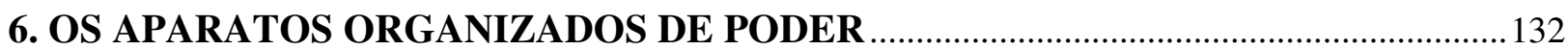

6.1. Introdução: a teoria de Claus Roxin sobre os aparatos organizados de poder: uma

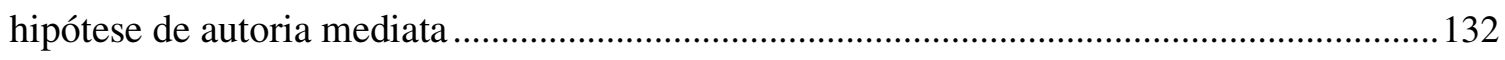

6.2. Requisitos do aparato organizado de poder segundo Claus Roxin .........................................136

6.3. Críticas à autoria mediata delineada por Claus Roxin ..............................................................138

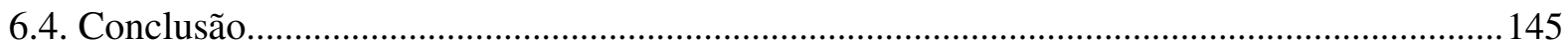

6.5. A teoria dos aparatos organizados de poder na jurisprudência ...............................................146

6.5.1. O julgamento dos Comandantes das Juntas Militares Argentinas (1985 e 1986) ........147

6.5.2. A decisão do Tribunal Federal Alemão (Bundesgerichtshof - BGH) no caso dos homicídios praticados pelos guardas que vigiavam o muro de Berlim (1994)............. 150

6.5.3. A decisão do Tribunal Supremo Espanhol no Caso Mancha Real (1994)..................... 154

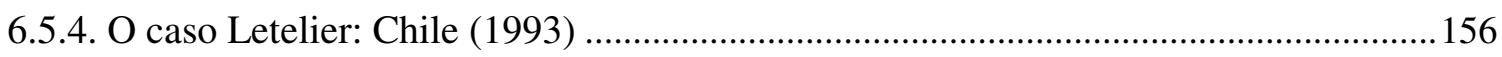

6.5.5. A jurisprudência peruana sobre os aparatos organizados de poder: nota prévia ...........158

6.5.5.1. A primeira decisão peruana: o Caso do Falso Fiscal (2007) 159 
6.5.5.2. A segunda decisão peruana: o Caso Abimael Guzmán. Líder do Sendero Luminoso (2007)

6.5.5.3. A terceira decisão peruana: o Caso Fujimori/La Cantuta/Barrios Altos (2009)

6.6. Aparato organizado de poder e as organizações empresariais 170

6.6.1. Introdução: a organização empresarial como aparato de poder ..... 170

6.6.2. Argumentos contrários à aplicação da teoria dos aparatos às empresas 172

6.6.3. Argumentos favoráveis à aplicação da teoria dos aparatos organizados de poder às sociedades empresárias 175

6.6.4. Tomada de postura: o critério da função social da empresa 179

6.6.5. A teoria da autoria mediata em razão de aparatos organizados de poder no Brasil: doutrina e análise crítica da jurisprudência. 


\section{INTRODUÇÃO}

\subsection{Abordagem do tema: justificativa para a escolha e a importância da investigação}

O tema "A imputação nas organizações empresariais" foi escolhido pela relevância do estudo dos modelos através dos quais uma pessoa física pode ser responsabilizada pela prática de um crime levado a efeito em uma organização empresarial, impondo-se, desde logo, uma importante observação: aqui não se cogitará da responsabilidade penal das pessoas jurídicas, mas exclusivamente da atribuição de responsabilidade penal dos indivíduos que a compõem e que, sob o contexto corporativo, praticaram delitos.

O presente trabalho parte da constatação de que a organização empresarial moderna representa uma realidade social emergente que não pode ser tratada como a mera soma de sujeitos individuais, bem como que, na atualidade, existe nas organizações empresariais mais complexas uma atomização ou fragmentação dos movimentos empresariais, o que se evidencia pela divisão ou estratificação sobre políticas gerais da empresa, conhecimento sobre os riscos dos produtos, execução material etc..

Sendo assim, a partir de certo grau de sofisticação, não é mais possível encontrar uma pessoa determinada sobre a qual recaiam, ao mesmo tempo, a criação do risco ou sua intervenção com o conhecimento do risco da atividade ou do produto ou mesmo uma pessoa que detenha a informação global sobre a atividade empresarial.

Essa realidade acarreta, no âmbito da criminalidade de empresa, uma enorme dificuldade para concretizar a imputação do indivíduo pelos crimes perpetrados no contexto das entidades empresariais, existindo, com efeito, um distanciamento entre a atividade de decisão, detenção de informação e poder de decisão que consubstancia, segundo observa Bernardo Feijoo Sánchez, o problema central para a constatação de 
responsabilidade penal ${ }^{1}$.

Assim, o estudo desenvolvido parte de dois pressupostos: (i) as ferramentas dogmáticas tradicionais não têm resolvido adequadamente os problemas de imputação penal e, por conseguinte, de tipicidade (material) dos fatos criminosos praticados no âmbito das organizações empresariais; (ii) a imputação penal no contexto dos delitos de organização deve ser concretizada com base no manancial jurídico-penal existente, recusando-se a adoção de um Direito Penal de segunda velocidade ${ }^{2}$ ou mesmo de um Direito de Intervenção ${ }^{3}$.

A propósito, no campo da tipicidade penal levou-se em conta que a concretização da imputação de condutas criminosas perpetradas principalmente no ambiente econômico tornou-se mais complexa diante da prodigiosa utilização, pelo legislador brasileiro, de elementos normativos, de tipos penais abertos, de normas penais em branco e de crimes de perigo abstrato.

Ao mesmo tempo, partindo-se da ideia que o tipo penal não se esgota na fórmula "matar alguém", bem como que, sob os auspícios de um Direito penal balizado pelo Estado Social e Democrático de Direito, a atribuição de responsabilidade de um fato delituoso a alguém - a imputação penal - estabelece-se, segundo será examinado, mediante critérios normativos que devem guardar consonância com a missão do Direito Penal, o estudo buscará abordar as várias faces da imputação penal no plano individual e no plano coletivo.

${ }^{1}$ FEIJOO SÁNCHEZ, Bernardo. Cuestiones actuales de derecho penal económico. Buenos Aires-Argentina: Editorial B de F, 2009. p. 3.

${ }^{2}$ Segundo o qual existiriam dois Direitos Penais, um nuclear (primeira velocidade), em que seriam mantidos os princípios do denominado Direito Penal Liberal-Clássico e outro periférico, no qual esses princípios seriam flexibilizados ou mesmo transformados, a fim de viabilizar a proteção penal das novas áreas postas em perigo (meio ambiente, consumidor, ordem econômica). Assim, as garantias clássicas do Direito Penal (conduta, nexo de causalidade e culpabilidade) poderiam ser mitigadas desde que isso não acarrete penas privativas de liberdade, mas somente penas pecuniárias ou restritivas de direito (Direito Penal de segunda velocidade) (cf. SILVA SÁNCHEZ, Jesús María. La expansión del derecho penal: aspectos de la política criminal en las sociedades postindustriales. 2. ed. Buenos Aires: B de F, 2008. p. 178 e ss.).

${ }^{3}$ Criado pelo alemão Winfried Hassemer, desenvolve-se no sentido de que se deve criar um novo campo jurídico (Direito de Intervenção), o qual seria responsável pelas lesões aos bens supraindividuais. Esse Direito de Intervenção nada tem de Direito Penal e seria localizado entre o Direito Administrativo e o Direito Penal e entre o Direito Civil e o Direito Público, incidindo sobre os delitos econômicos, drogas e crimes ambientais. Hassemer prega a descriminalização das condutas para reduzir o Direito Penal ao seu núcleo básico de proteção, ou seja, delitos de lesão a bens jurídicos individuais ou bens jurídicos supraindividuais estritamente vinculados à pessoa, delitos de perigo concreto graves e evidentes por regras rígidas de imputação e princípios de garantias clássicos. 
Como pano de fundo, levou-se em conta o fato de que alguns modelos de atribuição de responsabilidade penal (imputação) frequentemente utilizados no cotidiano forense têm suscitado verdadeiras e indesejáveis fricções com o postulado da responsabilidade penal subjetiva, notadamente em razão da incriminação - quase que automática - de administradores de sociedades empresárias exclusivamente por força de sua condição jurídica ${ }^{4}$.

Sob esse contexto, pareceu-nos adequada a verificação prévia do perfil organizacional da pessoa jurídica, ou seja, qual a conformação jurídica concretamente adotada pela sociedade empresária, com destaque para o exame da divisão de tarefas e da hierarquia de suas atividades, como forma de estabelecer, sem violência ao princípio da responsabilidade penal subjetiva, os critérios de imputação pelos fatos praticados no seio das organizações empresariais.

Assim, foi objeto de análise a tendência doutrinária de sustentar a responsabilização dos órgãos de direção por fatos praticados por intermédio da estrutura empresarial, e se observou o modo através do qual essa responsabilização se verificou nos casos concretos. A teoria da autoria mediata por meio de um aparato organizado de poder, por exemplo, foi objeto de estudo específico no Capítulo V ante a constatação que ela tem servido como veículo de atribuição de responsabilidade penal pelos atos praticados no seio das organizações empresariais, muito embora se adiante que seu próprio idealizador, o professor alemão Claus Roxin, seja manifestamente contrário a essa proposta de extensão ${ }^{5}$.

\footnotetext{
${ }^{4}$ Referimo-nos especificamente às denúncias promovidas em crimes societários que não individualizam pormenorizadamente as condutas dos agentes e que se restringem à indicação de que os acusados eram de algum modo responsáveis pela condução da sociedade comercial sob a qual foram praticados os delitos. Nessas hipóteses, parte significativa da jurisprudência do Supremo Tribunal Federal tem assinalado a inépcia da exordial acusatória por ofensa dos princípios constitucionais do devido processo legal e da dignidade da pessoa humana: HC 73.590; HC 86.879; HC 87.768; HC 89.105. Contra: HC 80.812; HC 85.579; HC 86.294. No Superior Tribunal de Justiça, contudo, a tendência é admitir a denúncia que, apesar de não descrever detalhadamente a conduta do acusado, demonstra o nexo entre os seus atos e a prática criminosa a estabelecer a plausibilidade da imputação, a partir de indícios como a condição de sócio ou administrador da empresa, o que possibilita, segundo no STJ, o exercício da ampla defesa (AgRg no Resp 130.9576; AgRg no Resp 126.5623; RHC 35.309; HC 260.390; RHC 40.317; RHC 38.261). Não obstante, existe posição contrária, com a qual concordamos, diga-se de passagem, no sentido de que a circunstância única de o agente ser sócio da empresa não é suficiente, por si só, para contra ele desencadear a persecutio criminis, se não demonstrado um mínimo de indícios de que tenha, ativa e diretamente, participado das ações delituosas (HC 188.225; HC 217.229).

${ }^{5}$ ROXIN, Claus. Autoria mediata por meio de domínio de organização. In: GRECO, Luís; LOBATO, Danilo (Coords.). Temas de direito penal: parte geral. Rio de Janeiro: Renovar, 2008. p. 323-342.
} 
O tema escolhido para estudo ainda assume dimensão teórica quando se tem presente a existência de um movimento doutrinário no sentido de que o empresário ou administrador da sociedade não detém uma genérica posição de garante pelo simples fato de exercer funções de comando empresarial, não se podendo imputar, assim, responsabilidade penal em razão do cometimento de um crime omissivo impróprio.

Dessa forma, a imputação penal desses atores pelo critério da posição de garante (art. 13, § $2^{\circ}$, do Código Penal brasileiro) demandou análise, em ordem a conferir se a figura do garantidor pode - ou não - ser extraída a partir de uma (i) posição meramente formal, ou, se de outro lado, derivaria de uma (ii) relação material de sua posição, (iii) do fato de ostentar um poder de organização real ou mesmo em razão (iv) do exercício aparente, ainda que irregular, de fato ou de fachada, das atividades de comando.

Enfim, o presente estudo pretendeu enfocar os modelos de imputação penal que melhor se adaptam às condutas delituosas realizadas pelos indivíduos no âmbito das organizações empresariais complexas e sua compatibilidade com o ordenamento jurídicopenal brasileiro.

\subsection{Casos de referência: alguns pontos de partida}

O estudo do Direito não pode ser dissociado da realidade. A aplicação das normas existentes no ordenamento jurídico depende de sua utilidade prática. Toda a teoria jurídica traz consigo um caráter pragmático ou, como lembram Luís Greco e Alaor Leite, nasce com a finalidade de resolver um problema concreto $^{6}$.

No Direito Penal, esse pragmatismo se corporifica na resolução de casos, ora reais, extraídos do cotidiano forense e da jurisprudência, ora imaginários, os quais servem como contraprova do acerto - ou do equívoco - da teoria.

Com efeito, a doutrina costumeiramente tem enfrentado casos como "teste"

\footnotetext{
${ }^{6}$ GRECO, Luís; LEITE, Alaor. O que é e o que não é a teoria do domínio do fato sobre a distinção entre autor e partícipe no Direito Penal. Revista dos Tribunais, São Paulo, v. 933, p. 62, jul. 2013.
} 
da utilidade prática da proposta teórica formulada. Na Alemanha e na Espanha, por exemplo, é comum a enunciação e a abordagem de questões fáticas no interior de monografias e manuais, em especial no âmbito do Direito Penal Econômico. O Direito Penal brasileiro tem tentado, obviamente, trilhar o mesmo caminho, embora não com a mesma profusão e criatividade, haja vista a escassez de julgados que tenham abordado, com profundidade, os diversos aspectos de fato e de direito que delineiam a imputação penal das pessoas físicas pelos crimes cometidos no âmbito das organizações empresariais.

Para a consecução do presente trabalho foram selecionados cinco casos de referência que demonstram as dificuldades da elaboração da imputação penal no âmbito das organizações empresariais complexas, a partir dos quais serão fincados alguns pontos de partida para a análise das soluções que, ao final da dissertação, serão apresentadas individualmente para cada hipótese fática. Dos cinco casos, um foi extraído de situação real enfrentada no curso de atividade profissional do candidato no Ministério Público Federal e ainda pende de decisão judicial na primeira instância da Justiça Federal de São Paulo e outro foi inspirado em um julgado realizado pelo Tribunal Regional Federal da $2^{\mathrm{a}}$ Região. Deixou-se deliberadamente de mencionar o nome ou qualquer outro dado indicativo das pessoas envolvidas para preservação do sigilo de suas identidades. Os outros três casos analisados foram criados, mas dizem respeito a situações perfeitamente factíveis.

Todos os casos foram escolhidos em razão da relevância e da amplitude da problemática que consubstancia o objeto da presente dissertação e as soluções propostas demonstram a sua pertinência prática.

Caso $n^{\circ} 1$ (inspirado em julgado do Tribunal Regional Federal da $2^{a}$ Região) $)^{7}$ cinco membros do Conselho de Administração do Banco " $\underline{X Z}$ ” foram

\footnotetext{
${ }^{7}$ Número CNJ: 0004965-22.2004.4.02.5001 - Relator Desembargador Federal Messod Azulay Neto. Ementa: PENAL E PROCESSUAL PENAL. APELAÇÕES CRIMINAIS INTERPOSTAS PELO MINISTÉRIO PÚBLICO FEDERAL E PELO RÉU. GESTÃO TEMERÁRIA EM INSTITUIÇÃO FINANCEIRA (ART. $4^{\circ}$, PARÁGRAFO ÚNICO, DA LEI No 7.492/86). MATERIALIDADE E AUTORIA COMPROVADAS. DOSIMETRIA. NÃO INCIDÊNCIA DA ATENUANTE DA CONFISSÃO ESPONTÂNEA. RECURSO MINISTERIAL PROVIDO E DESPROVIDO O RECURSO DEFENSIVO. I -Hipótese em que o réu, ora apelantelapelado, foi condenado por ter restado demonstrado que, na qualidade de Diretor do Banco do Estado do Espírito Santo- BANESTES, no período de 20/10/1993 a 22/11/1994, assinou 16 pareceres, juntamente com outros diretores, aprovando uma série de operações irregulares de crédito, em desacordo com as normas de boa gestão e segurança operacional, resultando em prejuízo no montante de $R \$$ 21.612.990,70 (vinte e um milhões, seiscentos e doze mil, novecentos e noventa reais e setenta centavos)
} 
condenados pelo cometimento do crime de gestão temerária de instituição financeira (art. $4^{\text {o }}$, único, da Lei n. ${ }^{o}$ 7.492/1986) porque votaram pela concessão de diversos empréstimos vultosos em desacordo com as normas de boa gestão e segurança operacional, resultando em prejuízo no montante de $\mathrm{R} \$ 21.612 .990,70$ (vinte e um milhões, seiscentos e doze mil, novecentos e noventa reais e setenta centavos) para a instituição financeira. A prova dos autos, emanada principalmente do relatório produzido pelo Banco Central do Brasil, indicou que os cinco membros do Conselho de Administração do Banco " $\underline{Y Z}$ ' autorizaram as operações bancárias em benefício de pessoas jurídicas sem exigir garantias suficientes, apesar de pareceres técnicos desfavoráveis que alertavam a presença de inúmeras restrições financeiras. Os empréstimos, contudo, foram concretamente efetivados pelo gerente da agência " $\underline{ }$ " do aludido Banco, em estrita obediência à resolução do órgão colegiado. Pergunta-se: considerando que a decisão de conceder empréstimos foi tomada pelo Conselho de Administração por maioria de votos (5 a 2), qual o título de imputação que deve ser atribuído aos cinco Conselheiros que votaram positivamente à realização dos empréstimos (autor, coautor ou partícipe)? É possível imputar a prática da gestão temerária aos dois Conselheiros dissidentes? Se positiva a resposta, a que título (autor, coautor ou partícipe)? Cabe atribuir responsabilidade penal ao gerente " $P$ ”? Se positiva a resposta, a que título (autor, coautor ou partícipe)?

Caso 2 (inspirado na imputação penal formulada nos autos da ação penal n. ${ }^{o}$ 2007.61.81.008823-6, em trâmite perante a $8^{a}$ Vara Criminal Federal de São Paulo): a partir de janeiro de 2007 até o dia 17 de julho de 2007, " $\underline{M A C}$ ", agindo na condição de Diretor de Segurança de voo da “ $\underline{T}$ ” Linhas Aéreas S/A (Safety), expôs a perigo aeronaves alheias mediante dolo eventual, pois, mesmo tendo conhecimento das péssimas condições de atrito e frenagem da pista principal do aeroporto " $\underline{C}$ ", em especial nos dias de chuva, bem como do conteúdo de norma da Agência Nacional de Aviação Civil (ANAC) e de sua relevância para a segurança do transporte aéreo, deliberadamente deixou de adotar

\footnotetext{
para a instituição financeira. II - Autoria e materialidade cabalmente comprovadas nos autos, especialmente pelo Relatório do BACEN que demonstra que o réu autorizou várias operações bancárias temerárias, cocedendo empréstimos a empresas, apesar de pareceres técnicos desfavoráveis que alertavam sobre restrições financeiras. III - O réu não confessou o crime pelo qual restou condenado, como se depreende de seu interrogatório judicial gravado na mídia audiovisual acostada à fl. 1766, bem como de suas razões recursais em que assevera a inocorrência de gestão temerária, sendo, pois, indevida a redução procedida na reprimenda pela incidência da atenuante prevista no art. $65, I I I, d$, do CP. IV - Recurso ministerial a que se DÁ PROVIMENTO. DESPROVIDO o recurso defensivo.
} 
providências para que, após inúmeros avisos no sentido de que a pista principal do aeroporto " $\underline{C}$ " estava escorregadia, as aeronaves da " $\underline{T}$ " Linhas Aéreas fossem redirecionadas para outro aeroporto, deixando, ainda deliberadamente, a partir do mês de janeiro de 2007, de divulgar aos pilotos da " $T$ " Linhas Aéreas que o procedimento de operação com o reversor desativado (pinado) da aeronave Airbus A-320, havia sido mudado (BS-A-320-31-1267), sendo que, em 17 de julho de 2007, por volta de 18h48min, no Aeroporto Internacional de " $\underline{C}$ ”, desse fato resultou a completa destruição da aeronave modelo AIRBUS A-320, operada pela " $\underline{T}$ ” Linhas Aéreas S/A, que realizava o voo JJJ, e a morte de 100 (cem) pessoas, tornando-se incurso, por conseguinte, no crime do 261 do Código Penal brasileiro (atentado à segurança de transporte aéreo). Diante desse fato, pergunta-se: " $\underline{M A C}$ " ostentava posição de garante no seio da " $\underline{T}$ ” Linhas Aéreas S/A? Essa condição proporciona a atribuição de responsabilidade penal por omissão dolosa?

Caso 3 (sociedade empresária que nasce lícita, mas posteriormente passa a cometer sistematicamente crimes contra o sistema financeiro nacional): a sociedade empresária denominada " $P C C$ " foi criada pelos sócios " $\underline{X}$ " e " $\underline{R}$ " como uma corretora de títulos e valores mobiliários (CTVM) em 2006. A " $\underline{P C C}$ " é administrada exclusivamente por " $\underline{ }$ " e conta com aproximadamente cinquenta funcionários hierarquicamente divididos com expressa divisão de funções. Sucede que, a partir do ano de 2010, por ordens explícitas de " $\underline{X}$ " a seus subordinados, a " $\underline{P C C}$ " passou a emitir, oferecer e negociar sistematicamente valores mobiliários falsos a seus clientes, conduta tipificada no artigo $7^{\circ}$ da Lei n. ${ }^{\circ}$ 7.492/1986. Esse procedimento criminoso passou a constituir a integralidade das atividades da " $\underline{P C C}$ ". Além disso, também por ordem de “ $\underline{X}$ ”, os recursos obtidos com os crimes cometidos eram posteriormente reciclados e dissimulados em contas abertas na Suíça em nome da sociedade offshore " $\underline{P C C I N C .}$. . Assim, pergunta-se: a sociedade empresária " $\underline{P C C}$ " pode ser equiparada a uma organização criminosa? Se positiva a resposta, como deve ser realizada a imputação penal de " $\underline{X}$ "? Neste caso, é possível cogitar a ocorrência de um aparato organizado de poder? Se positiva a resposta, essa cogitação interfere na condição jurídica da imputação penal de " $\underline{X}$ ”?

Caso 4 (crime contra as relações de consumo praticado no contexto de organização empresarial): o conselho de administração de uma Sociedade Anônima decide, pelo voto unânime dos conselheiros " $\underline{A}$ ", “ $\underline{B}$ ”, “ $\underline{C}$ ” e “ $\underline{D}$ ”, cortar os gastos de um 
determinado produto alimentício através da adição de uma substância nova chamada " $\underline{ }$ ", que substitui outra, de nome " $\underline{P}$ ", de valor mais alto, visando, com isso, maximizar os lucros. Não obstante, existem diversos estudos técnicos indicando que substância " $\underline{T}$ ", ainda sob teste, é potencialmente prejudicial à saúde dos consumidores. A decisão de substituição da substância " $P$ " foi comunicada ao departamento de vendas da companhia, formado pelas pessoas de " $\underline{X}$ ” e " $\underline{ }$ " que, a seu turno, determinaram que os funcionários “ $\underline{M}$ " e " $\underline{O}$ " modificassem os rótulos da embalagem do produto, omitindo os dizeres sobre a nocividade do produto. Diante desse quadro, indaga-se: como deve ser concretizada a imputação penal das diversas pessoas envolvidas que compõem a organização empresarial?

Caso 5 (crime contra o meio ambiente): funcionário do setor de transporte da sociedade empresária de nome " $\underline{ }$ ”, atendendo às ordens do gerente " $\underline{ }$ ", despeja no leito de um rio material tóxico resultante da atividade de empresa. Descobre-se, posteriormente, que essa conduta acarretou a mortandade de diversos animais e peixes, dando ensejo, portanto, à incidência do crime do artigo 54 da Lei n. ${ }^{\circ}$ 9.605/1998 . " $\underline{ }$ " tinha conhecimento direto do potencial tóxico da substância descartada, pois teve acesso a estudos técnicos que assinalavam expressamente essa circunstância. " $\underline{X}$ ” suspeitava que a substância fosse tóxica, uma vez que ouviu vários boatos nesse sentido dentro da pessoa jurídica e porque também viu diversos animais e peixes mortos ao longo do leito do rio. Ante esse relato, pergunta-se: como deve ser concretizada a imputação penal das diversas pessoas físicas envolvidas que compõem a organização empresarial “ $\underline{X}$ ”?

\footnotetext{
${ }^{8}$ Art. 54. Causar poluição de qualquer natureza em níveis tais que resultem ou possam resultar em danos à saúde humana, ou que provoquem a mortandade de animais ou a destruição significativa da flora: Pena reclusão, de um a quatro anos, e multa.
} 


\section{IMPUTAÇÃO PENAL}

\subsection{Introdução: o que significa imputar uma conduta criminosa a alguém?}

No Direito Penal o verbo imputar significa atribuir o cometimento de um fato delituoso a alguém, pessoa física ou jurídica ${ }^{9}$. A imputação assume singular relevância, pois serve de elo entre a conduta fenomênica, praticada no mundo dos fatos, e o tipo penal delineador de uma norma penal incriminadora, gerando responsabilidade penal.

Como observa Joachim Hruschka, sempre que contemplamos uma específica ação ou a omissão de uma específica ação, essa ação percebida representa o produto de um processo de imputação que ordinariamente não pode ser confundido com as regras de comportamento, cujos destinatários, analisados sob o prisma prospectivo, são pessoas submetidas às regras de caráter prescritivo, proibitivo ou permissivo ${ }^{10}$. Na imputação, ao revés, tem-se uma atividade essencialmente retrospectiva realizada pelo aplicador da norma, no caso, o juiz ${ }^{11}$.

Costuma-se distinguir doutrinariamente dois momentos através dos quais a imputação penal deve ser elaborada: o primeiro, denominado imputatio facti, diz respeito à relação de causalidade estabelecida com base em critérios físicos ou mecânicos, atribuindo-se determinado resultado a dada conduta; o segundo é o da imputatio delicti ${ }^{12}$.

\footnotetext{
${ }^{9}$ A imputação penal das pessoas jurídicas, no Brasil, tem-se restringindo, segundo o entendimento majoritário da doutrina, às violações ao meio ambiente, na esteira do que dispõe o artigo $225, \S 3^{\circ}$, da Constituição da República e a correspondente Lei n. ${ }^{\circ}$ 9.605/1998, embora se possa cogitar, também, de responsabilização do ente coletivo no campo dos crimes contra o sistema financeiro nacional, em razão do disposto no artigo 173, § 5º do Texto Constitucional. Sobre a discussão: SHECAIRA, Sérgio Salomão. Responsabilidade penal da pessoa jurídica. 3.ed. Rio de Janeiro: Elsevier, 2011. p. 121-133.

${ }^{10}$ HRUSCHKA, Joachim. Imputación y derecho penal: estudios sobre la teoría de la imputación. NavarraEspaña: Editorial Aranzadi, 2005. p. 22 e p. 28.

${ }^{11}$ Id. Ibid., p. 23.

${ }^{12}$ REALE JÚNIOR, Miguel. Instituições de direito penal: parte geral. 2. ed. Rio de Janeiro: Forense, 2006. v. 1, p. 247.
} 
Everardo da Cunha Luna discorda, todavia, da distinção entre imputatio facti e imputatio delicti e vai além. Luna destaca a prescindibilidade de disciplina legal do nexo causal ${ }^{13}$ e a consequente criação de diversas teorias doutrinárias que, até o momento, revelaram-se insatisfatórias para a resolução do problema da causalidade, a qual, aliás, somente assoma útil para um "grupo particular de crimes"14. Segundo o professor da Faculdade de Direito do Recife, o Código Penal disciplina fatos e nunca relações, sendo que, existem "cinco relações fundamentais no direito penal, três das quais puras categorias jurídicas, isto é, relações entre o fato e a norma: a antijuridicidade - relação de contrariedade entre o fato do homem e a norma jurídica; a tipicidade - relação de adequação entre o fato do homem e a descrição legal; a punibilidade - relação de adequação entre o fato do homem e a sanção penal. As outras duas relações são relações de fato e fato: a causalidade - relação entre a ação e o resultado; a culpabilidade - relação entre a vontade e a ação" ${ }^{15}$.

A tarefa de imputar pode parecer simples ou verificável de modo quase automático naquelas situações em que o resultado produzido atrela-se imediatamente à pessoa que o provocou dolosamente, desde que não exista espaço para dúvida na relação causal. Exemplificamos: " $\underline{X}$ ” descarrega todos os projéteis de sua arma de fogo contra " $\underline{Y}$ ", causando-lhe a morte imediata. A " $\underline{X}$ " deve ser imputada a conduta de "matar alguém", definida no artigo 121 do Código Penal, pois ele deliberadamente provocou o resultado morte em " $\underline{Y}$ ", definido no Código Penal brasileiro como crime de homicídio. Isso, obviamente, se ficar demonstrado no curso do processo penal, mediante a juntada do laudo de exame de corpo de delito, que a morte de " $\underline{Y}$ " decorreu efetivamente dos disparos proferidos por " $\underline{\text { }}$ ” ou, para ser mais claro, que " $\underline{X}$ ” causou a morte de ' $\underline{\text { }}$ '.

\footnotetext{
${ }^{13}$ Em sentido contrário: REALE JÚNIOR, Miguel. Instituições de direito penal: parte geral, cit., v. 1, p. 254.

${ }^{14}$ LUNA, Everardo da Cunha. Estrutura jurídica do crime. 4. ed. São Paulo: Saraiva, 1993. p. 182-183.

${ }^{15}$ Id. Ibid., p. 183. Everardo da Cunha Luna critica os adeptos de um naturalismo radical, tratando o nexo de causalidade de maneira híbrida, misturando elementos naturais a elementos psicológicos: "O apelo ao elemento psicológico do crime, para a satisfatória solução do problema causal, não é defeito, mas imposição dos fatos, dos fatos puníveis que são, a um só tempo, materiais e psíquicos. Só o naturalismo, que busca, em vão, separar o objetivo do subjetivo em matéria penal, combate seja o problema da causalidade resolvido à luz do problema da culpabilidade. Assim como não se entende ação sem vontade, assim também não se compreende causalidade física sem causalidade psíquica" (LUNA, Everardo da Cunha. Estrutura jurídica do crime, cit., p. 81). No mesmo sentido: Miguel Reale Júnior (Teoria do delito. São Paulo: Ed. Revista dos Tribunais, 1998. p. 173).
} 
Existem situações, contudo, que a mera causação de um resultado considerado criminoso não pode ser equiparada à imputação e, assim, ensejar a atribuição de responsabilidade penal. Veja-se o seguinte caso inspirado no hoje clássico exemplo desenhado por Claus Roxin ${ }^{16}$ : o sobrinho " $\underline{M}$ " convida seu tio " $\underline{P}$ ” para uma viagem internacional de avião, pretendendo, intimamente, que ele morra durante o voo, pois com isso " $\underline{M}$ " herdaria todo o seu vultoso patrimônio. Durante o trajeto, as sondas que medem a velocidade do avião se congelaram quando ele passava por uma zona de turbulência, acarretando a queda da aeronave e, em consequência, a morte do tio " $\underline{P}$ ".

Diante desse quadro poder-se-ia perguntar: qual foi a causa da morte de " $\underline{P}$ ”? A resposta: a queda do avião. Por que " $\underline{P}$ " estava no avião? Resposta: porque foi convidado por " $\underline{M}$ ". A conclusão: " $\underline{M}$ " deu causa à morte de " $\underline{P}$ ". Além disso, " $\underline{M}$ " agiu com patente ânimo de matar (animus necandi), de modo que a ele deve ser imputado o resultado morte. Correto? Não, pois a causação, ou juízo de causalidade de um resultado não se confunde com a ideia de imputação. Pode existir causalidade, como no pedagógico exemplo de Roxin, e não se ter imputação penal. Em outro dizer: é possível claramente detectar situações nas quais o sujeito voluntariamente praticou uma ação, mas a ele não pode ser atribuído penalmente o resultado, de dano ou de perigo, pela ausência de um critério normativo ligado à imputação penal. Nesses casos, o sujeito somente pode ser considerado causador do resultado, mas não o seu responsável, ou melhor, seu autor ${ }^{17}$.

\subsubsection{Três conclusões preliminares}

Em sede introdutória, a primeira conclusão que pode ser extraída é a de que a imputação do resultado a um sujeito não se esgota na relação de causalidade, na mera ligação naturalística estabelecida entre o comportamento e o resultado.

\footnotetext{
${ }^{16}$ ROXIN, Claus. Funcionalismo e imputação objetiva no direito penal. Tradução e introdução de Luís Greco. Rio de Janeiro: Renovar, 2002. p. 304.

${ }^{17}$ Em sentido semelhante: HRUSCHKA, Joachim. Imputación y derecho penal: estudios sobre la teoría de la imputación, cit., p. 30-31.
} 
Como adverte Jorge de Figueiredo Dias, se considerada exclusivamente sob o aspecto naturalístico, empírico ou mecanicista, a causalidade pode servir tão-somente como o limite ou o patamar máximo de imputação penal $^{18}$, e não a primeira, ou a única, etapa de atribuição de responsabilidade penal.

A segunda conclusão é a de que as regras tradicionais de imputação ${ }^{19}$ mostram-se, atualmente, insuficientes para resolver a maior parte dos problemas penais que surgem no contexto de uma economia globalizada ${ }^{20}$ e no seio da sociedade de risco ${ }^{21}$.

A terceira e última conclusão, que é derivada da segunda, é a de que a imputação penal deve ser compreendida como uma categoria essencialmente normativa a ser concretizada segundo a racionalidade própria da dogmática jurídico-penal e,

\footnotetext{
${ }^{18}$ DIAS, Jorge de Figueiredo. Direito penal: parte geral: questões fundamentais: a doutrina geral do crime. 1. ed. bras., 2. ed. port. São Paulo: Ed. Revista dos Tribunais; Coimbra Ed., 2007. t. 1, p. 323. Em semelhante perspectiva, Francisco Muñoz Conde reputa a relação de causalidade entre a conduta e o resultado como "pressuposto mínimo de responsabilidade nos delitos de resultado" (MUÑOZ CONDE, Francisco. Teoria geral do delito. Tradução e notas por Juarez Tavares e Luis Regis Prado. Porto Alegre: Sergio Antonio Fabris Editor, 1988.p. 22).

${ }^{19}$ Se é que podemos tratar os critérios tradicionais de atribuição de responsabilidade penal como verdadeiros modelos de imputação.

${ }^{20}$ Para o fenômeno da globalização por uma óptica sociológica: CASTELLS, Manuel. A sociedade em rede: a era da informação: economia, sociedade e cultura. Tradução de Roneide Venancio Majer. 6. ed. São Paulo: Paz e Terra, 2009. v. 1, p. 147. Para globalização e Direito Penal: FRANCO, Alberto Silva. Globalização e criminalidade dos poderosos. In: PODVAL, Roberto (Org.). Temas de direito penal economico. São Paulo: Ed. Revista dos Tribunais, 2000. p. 235-256; MACHADO, Maíra Rocha. Internacionalização do direito penal: a gestão de problemas internacionais por meio do crime e da pena. São Paulo: Editora 34, 2004. (Coleção Direito GV); RODRIGUES, Anabela Miranda. A globalização do direito penal: da pirâmide à rede ou entre a unificação e a harmonização. In: INSTITUTO DE DIREITO PENAL ECONÓMICO E EUROPEU. Direito penal económico e europeu: textos doutrinários. Coimbra: Coimbra Ed., 2009. v. 3, p. 81-91; COSTA, José de Faria. A criminalidade em um mundo globalizado: ou plaidoyer por um direito penal não-securitário. In: INSTITUTO DE DIREITO PENAL ECONÓMICO E EUROPEU. Direito penal económico e europeu: textos doutrinários. Coimbra: Coimbra Ed., 2009. v. 3, p. 113-123.

${ }^{21}$ Esclareça-se que não adotamos, de modo absoluto, ou seja, sem temperamentos, o conceito ou mesmo a existência de uma sociedade de risco, tal como concebida por Ulrich Beck (La sociedad del riesgo: hacia una nueva modernidad. Barcelona: Ediciones Paidós, 2008). Nesse sentido, tomamos por base a opinião de Vicente Greco Filho e de João Daniel Rassi, segundo a qual "Toda a sociedade tem seu risco e, até, pode-se dizer que a sociedade atual tem risco menor que a do século XV ou XVI, bastando para isso demonstrar a expectativa de vida daquela época e a de hoje. Se a expectativa de vida aumentou significa que os riscos diminuíram ou, se aumentaram, foram acompanhados de medidas reais e efetivas de sua atenuação" (GRECO FILHO, Vicente; RASSI, João Daniel. Lei de drogas anotada: Lei n. 11.343/2006. 2. ed. São Paulo: Saraiva, 2008. p. 75). Não ignoramos, porém, a existência de um sólido movimento doutrinário no sentido de admitir o padrão sociológico fotografado por Beck e analisar sua influência no Direito Penal brasileiro. Nesse diapasão: Alamiro Velludo Salvador Netto (Tipicidade penal e sociedade de risco. São Paulo: Quartier Latin, 2006. p. 81-90) e Pierpaolo Cruz Bottini (Crimes de perigo abstrato. 2. ed. São Paulo: Ed. Revista dos Tribunais, 2010. p. 29-48).
} 
particularmente, da dogmática do tipo penal ${ }^{22}$. Até porque, se como recorda Jakobs, o conteúdo da imputação depende do correspondente contexto social $^{23}$, qualquer imputação dissociada dos valores da sociedade soaria artificial e, portanto, juridicamente equivocada.

\subsection{Imputação penal e nexo de causalidade: insuficiência dos critérios tradicionais}

A insuficiência da relação de causalidade para a concretização da imputação penal com base na tradicional teoria da equivalência dos antecedentes causais (conditio sine qua non $)^{24}$ e no correspondente método de eliminação hipotética de Thyrén ${ }^{25}$, se revela patente na atualidade quando confrontada com algumas figuras delituosas que escapam da clássica fórmula do crime comissivo material ou de resultado ou de evento ${ }^{26}$, como acontece com os crimes omissivos puros e os crimes de mera atividade ${ }^{27}$.

\footnotetext{
${ }^{22}$ DIAS, Jorge de Figueiredo. Direito penal: parte geral: questões fundamentais: a doutrina geral do crime, cit., t. 1, p. 322.

${ }^{23}$ JAKOBS, Günther. La imputación objetiva en derecho penal. Tradução Manuel Cancio Meliá. 1. ed. Buenos Aires: Ad-Hoc, 2005. p. 17.

${ }^{24}$ Cuja essência parte da ideia de que causa é toda ação ou omissão sem a qual o resultado não teria ocorrido como ocorreu e ao tempo em que ocorreu. Tradicionalmente afirma-se que a teoria surgiu por obra de Maximiliam Von Buri, embora Heleno Claudio Fragoso ressalve que há quem entenda que a formulação da teoria surgiu no Direito Penal austríaco, com Glaser (FRAGOSO, Heleno Cláudio. Conduta punível. São Paulo: José Bushatsky Editor, 1961. p. 92). Hans-Henrich Jescheck e Thomas Weigend caminham nesse mesmo sentido, atribuindo a Julius Glaser a criação pioneira da teoria da conditio sine qua non (JESCHECK, Hans-Henrich; WEIGEND, Thomas. Tratado de derecho penal: parte general. 5. ed. Granada: Comares, 2002. p. 299). A mais notória crítica à teoria da equivalência dos antecedentes causais reside no denominado regresso ao infinito (regressus ad infinitum), fato que, a toda evidência, pode redundar em demasiado alargamento da responsabilidade penal. "Assim, o fabricante da arma que causou o homicídio seria guinchado a co-autor do crime" (COSTA JR., Paulo José da. Curso de direito penal. 9. ed. São Paulo: Saraiva, 2008. p. 75).

${ }^{25}$ Segundo o qual, para se verificar se determinado evento é causa, deve-se retirá-lo mentalmente da relação causal; se mesmo assim o resultado teria ocorrido como ocorreu e ao tempo em que ocorreu, o evento não pode ser considerado causa do resultado. Nesse diapasão: HUNGRIA, Nélson. Comentários ao Código Penal. Rio de Janeiro: Forense, 1958. v. 1, t. 2, p. 66.

${ }^{26}$ Onde o método de eliminação hipotética de Thyrén parece resolver a grande parte dos casos. Daí a assertiva de Miguel Reale Júnior, no sentido de que o "nexo causal é matéria que apresenta dificuldades teóricas, mas certa facilidade prática, mesmo porque a relação de causalidade tem realce apenas em alguns delitos, por exemplo, homicídios, lesões corporais, incêndio. Na verdade, tão-somente para alguns dos delitos, cujo resultado é naturalístico, tem relevância a relação de causalidade, como, aliás, assinalava a Exposição de Motivos do Professor Gama e Silva ao Código Penal de 1969" (REALE JÚNIOR, Miguel. Teoria do delito, cit., p. 172).

${ }^{27}$ FRAGOSO, Heleno Cláudio. Conduta punível, cit., p. 90. Mais recentemente, mas na mesma linha: ROXIN, Claus. Derecho penal: parte general: fundamentos. La estructura de la teoría del delito. Madrid: Civitas, 2008. t. 1, p. 345.
} 
Em relação aos crimes omissivos impróprios (ou comissivos por omissão), por exemplo, costuma-se afirmar que a imputação não reclama uma "relação de causalidade propriamente dita, mas apenas que o sujeito não tenha impedido o resultado quando podia e devia fazê-lo, em razão de sua condição de garante $^{\text {"28. }}$.

A questão, todavia, não pode ser resolvida assim, de modo imediato e simplista, mormente se tivermos em vista que a imputação nos crimes omissivos impróprios tem servido de campo fertilmente rico para o desenvolvimento de intenso debate acadêmico, consoante se verificará em Capítulo específico do presente trabalho.

Não obstante, por ora, basta ter em perspectiva a posição de Juarez Cirino dos Santos, emanada no sentido de que, por exigir a eleição de um garante, a omissão de ação imprópria conflitaria com o princípio da legalidade, quer no plano da proibição da analogia, quer no plano da vedação da indeterminação penal ${ }^{29}$. Especificamente em relação à segunda hipótese, Cirino dos Santos ressalta que, mesmo após a Reforma da Parte Geral em 1984, a redação conferida ao artigo $13, \S 2^{\circ}$, do Código Penal, não foi capaz de determinar os resultados da lesão dos bens jurídicos atribuíveis ao garantidor, embora tenha definido os fundamentos do dever jurídico de evitar o resultado ${ }^{30}$.

E mais: a única maneira de compatibilizar os crimes omissivos impróprios com a proibição de indeterminação decorrente do princípio da legalidade residiria na imposição de limitar a responsabilidade penal do garantidor "aos bens jurídicos individuais mais importantes, como a vida e o corpo do sujeito garantido: a extensão da garantia a

\footnotetext{
${ }^{28}$ BITENCOURT, Cezar Roberto. Tratado de direito penal: parte geral. 17. ed. São Paulo: Saraiva, 2012. v. 1, p. 320.

${ }^{29}$ SANTOS, Juarez Cirino dos. Direito penal: parte geral. 4. ed. rev. e ampl. Florianópolis: Conceito Editorial, 2010. p. 193. Na mesma esteira, Eugenio Raúl Zaffaroni e José Henrique Pierangeli asseveram: “O problema mais grave suscitado pela omissão imprópria está em que, de acordo com a doutrina dominante, nem todos os tipos de omissão imprópria - nem mesmo os mais importantes - estão expressos em lei" (ZAFFARONI, Eugenio Raúl; PIERANGELI, José Henrique. Manual de direito penal brasileiro: parte geral. 4. ed. São Paulo: Ed. Revista dos Tribunais, 2002. p. 541). Não se pode deixar de consignar, porém, que, se de um lado Zaffaroni e Pierangeli têm a impressão que nos crimes omissivos impróprios "o princípio da legalidade passa a sofrer uma importante exceção", de outro lado eles admitem que "a admissão dos tipos omissivos impróprios não expressos não faz mais do que esgotar o conteúdo proibitivo do tipo ativo, que de modo algum quis deixar certas condutas fora da proibição. Nesse último sentido, parece quase óbvio que quando o CP comina pena gravíssima a morte do pai, não quer deixar fora dessa tipicidade a conduta da mãe que, ao invés de estrangular seu bebê, o deixa morrer de inanição" (ZAFFARONI, Eugenio Raúl; PIERANGELI, José Henrique. Manual de direito penal brasileiro: parte geral, cit., p. 541).

${ }^{30}$ SANTOS, Juarez Cirino dos. Direito penal: parte geral, cit., p. 196.
} 
todos os tipos de resultado de lesão, incluindo o patrimônio, a sexualidade, ou - ainda mais grave - o sistema financeiro, o meio ambiente etc., embora tecnicamente admissível, implicaria um dever jurídico indeterminável e excessivo, incompatível com a Constituição da República"31.

Não se justifica, porém, a nosso ver, que alguns bens jurídicos sejam merecedores de proteção penal pela via da omissiva imprópria, enquanto outros não ${ }^{32}$. É certo que a Constituição da República brasileira não possui tábua valorativa, ou seja, não indica, pelo menos expressamente, se determinado bem é mais ou menos importante que outro. $\mathrm{O}$ artigo $5^{\circ}$, caput, da Carta Magna, por exemplo, arrola, sob um mesmo período, como sendo dignos de tutela, a vida, a liberdade, a igualdade, a segurança e a propriedade, sem efetivar diferenciação de qualquer natureza ${ }^{33}$. A nosso ver o Direito Penal brasileiro não acolhe distinções valorativas entre os bens jurídicos protegidos para a concretização da imputação penal. Veja-se o caso da legítima defesa: a não incidência do tipo penal e a correspondente atribuição do resultado ao agente são excluídas com o afastamento da ilicitude independentemente da cogitação da natureza do bem jurídico envolvido na situação de conflito. Pode-se matar para salvar a propriedade, desde que haja moderação ${ }^{34}$.

\footnotetext{
${ }^{31}$ SANTOS, Juarez Cirino dos. Direito penal: parte geral, cit., p. 196.

${ }^{32}$ Juarez Cirino dos Santos parece seguir, nesse específico aspecto, a denominada Escola de Frankfurt, de onde se destacam nomes como Herzog, Prittwitz, P.A Albrecht e, principalmente, Hassemer, cuja base repousa, justamente, na classificação e na distinção valorativa de bens jurídicos, bem como pela crítica às manifestações contemporâneas do Direito Penal em expansão. Sobre o tema, em especial a obra de Hassemer, de ver-se a excepcional monografia de Ana Carolina Carlos de Oliveira intitulada Hassemer e o direito penal brasileiro: direito de intervenção, sanção penal e administrative. 1. ed. São Paulo: IBCCRIM, 2013. p. 26-28.

${ }^{33} \mathrm{O}$ fato de existir posicionamento doutrinário no sentido de que, ao mencionar na cabeça do artigo $5^{\circ} \mathrm{o}$ direito à segurança o legislador constituinte se referiu, em verdade, a uma categoria de garantias fundamentais não retira, evidentemente, a necessidade de proteção no mesmo patamar de outros direitos individuais. Mesmo porque, como põe em relevo José Afonso da Silva, "esse conjunto de direitos aparelha situações, proibições, limitações e procedimentos destinados a assegurar o exercício e o gozo de algum direito fundamental (intimidade, liberdade pessoa ou a incolumidade física ou moral)" (SILVA, José Afonso da. Curso de direito constitucional positivo. 16. ed. São Paulo: Malheiros Ed., 1999. p. 437).

${ }^{34}$ Anote-se Eugenio Raúl Zaffaroni e José Henrique Pierangeli: "O requisito da moderação da defesa não exclui a possibilidade de defesa de qualquer bem jurídico, apenas exigindo uma certa proporcionalidade entre a ação defensiva e a agressiva, quando tal seja possível, isto é, que o defensor deve utilizar o meio menos lesivo que tiver ao seu alcance" (ZAFFARONI, Eugenio Raúl; PIERANGELI, José Henrique. Manual de direito penal brasileiro: parte geral, cit., p. 580). No mesmo sentido, Francisco de Assis Toledo: "no moderno direito penal, embora não se exija, na legítima defesa, balanceamento de bens nos moldes do estado de necessidade, só se admite a defesa de bens insignificantes (note-se que não excluímos a possibilidade) quando os atos necessários e suficientes para tanto não causarem lesão ao agressor de forma expressivamente desproporcionada ao valor dos bens e interesses ameaçados” (TOLEDO, Francisco de
} 
Além disso, Cirino dos Santos não justifica a razão pela qual a responsabilização penal do agente garantidor ficaria circunscrita aos bens individuais. De fato, tendo presente que a Constituição da República de 1988 estipulou direitos de terceira e quarta geração, prestigiando claramente o resguardo de direitos transindividuais ${ }^{35}$, não existe, pelo menos sob a luz do texto constitucional, motivo para qualquer discriminação.

Outra crítica à insuficiência da teoria da conditio sine qua non está relacionada àquelas hipóteses que refogem do fluxo causal normal (cursos causais normais), ou seja, casos cujos resultados podem ser extraídos, sem muita dificuldade, de um fato que habitualmente tem a capacidade de produzi-los e que podem ser aferidos por uma pessoa de conhecimento mediano ${ }^{36}$. Referimo-nos, no ponto, aos cursos causais irregulares, cursos causais cumulativos ou adicionais, cursos causais não verificáveis e cursos causais alternativos e hipotéticos ${ }^{37}$. Para esses casos, particularmente para os cursos causais alternativos e hipotéticos, adverte Claus Roxin, além de inútil, a utilização da fórmula da equivalência pode induzir verdadeiramente o intérprete em equívoco ${ }^{38}$.

No curso causal irregular existe uma linha causal na qual incide uma sucessão única de acontecimentos irregulares, isto é, que são estranhos ao desenvolvimento natural dos fatos. É o caso, manejado por Juan Carlos Ferré Olivé, Miguel Ángel Núñez Paz, William Terra de Oliveira e Alexis Couto de Brito, do sobrinho que, pretendendo

Assis. Ilicitude penal e causas de sua exclusão. Rio de Janeiro: Forense, 1984. p. 83). No ponto, porém, não pode passar despercebida a coerência do Professor Cirino dos Santos ao mencionar, em comentário específico sobre o instituto da legítima defesa, que todos os "bens jurídicos individuais são suscetíveis de legítima defesa (vida, saúde, liberdade, honra, propriedade etc.), mas existe controvérsia quanto aos bens jurídicos sociais: a) bens jurídicos da comunidade (ordem pública, paz social, regularidade do tráfego de veículos etc.) são insuscetíveis de legítima defesa porque a ação violenta do particular produziria maior dano que utilidade e, afinal, parece inconveniente atribuir ao povo tarefas próprias de polícia, embora alguns autores admitam a defesa do ser social ou comunitário pelo indivíduo; b) bens jurídicos do Estado, como o patrimônio público (destruição de cabines telefônicas, danos em trens de metrô etc.), admitem legítima defesa do particular - mas não a pessoa jurídica do Estado porque parece inadequado transformar o cidadão em guerreiro contra inimigos do Estado (espiões ou traidores, por exemplo)" (SANTOS, Juarez Cirino dos. Direito penal: parte geral, cit., p. 227).

${ }^{35}$ Indicados expressamente no artigo $6^{\circ}$ da Constituição da República e em outros artigos do Texto Constitucional, como, por exemplo, o artigo 170 (ordem econômica e financeira), o artigo 192 (sistema financeiro nacional), o artigo 193 (ordem social) e o artigo 225 (meio ambiente).

${ }^{36}$ FERRÉ OLIVÉ, Juan Carlos; ÁNGEL NÚÑEZ PAZ, Miguel; OLIVEIRA, William Terra de; BRITO, Alexis Couto de. Direito penal brasileiro: parte geral, princípios fundamentais e sistema. São Paulo: Ed. Revista dos Tribunais, 2011. p. 270.

${ }^{37}$ Id. Ibid., p. 270.

${ }^{38}$ ROXIN, Claus. Derecho penal: parte general: fundamentos. La estructura de la teoría del delito, cit., t. 1, p. 350 . 
herdar a fortuna de um tio, envia-o a uma viagem de avião em um dia de tempestade com manifesto animus necandi, sendo que, em razão das fortes chuvas, o resultado pretendido efetivamente vem a ocorrer ${ }^{39}$. Note-se que, para os efeitos da teoria da conditio sine qua non, o mal-intencionado sobrinho inegavelmente deu causa à queda da aeronave e, por consequência, ao resultado morte, pois se abstrairmos mentalmente a sua conduta, o resultado não teria ocorrido concretamente como ocorreu. Não obstante, conforme será oportunamente demonstrado, embora tenha dado causa ao evento morte e tenha agido com manifesto dolo de matar, ao sobrinho não pode ser imputada a conduta por lhe faltar condição normativa consubstanciada na criação de um risco desaprovado ao bem jurídico.

De outro lado, cogitar-se-á de curso causal cumulativo ou adicional quando o resultado produzido derivar do concurso de várias condições, sendo que cada uma delas resultaria suficiente, se considerada isoladamente, para produzir o mesmo resultado criminoso $^{40}$. Imaginem-se duas pessoas, " $\underline{\underline{ }}$ ” e “ $\underline{K}$ ”, os quais possuem o desiderato de eliminar a vida de " $\underline{W}$ ”, inimigo de ambos. " $\underline{Z}$ ” e " $\underline{K}$ ” têm doses de veneno suficientes para produzir o evento morte em " $\underline{W}$ ” e, desconhecendo cada qual a conduta do outro, despejam o veneno na bebida de “ $W$ ”, depois de ingeri-la ${ }^{41}$. Aplicando-se a eliminação hipotética, “ $\underline{Z}$ ' e " $\underline{K}$ ” poderiam aduzir a inexistência de responsabilidade, sob o argumento de que a conduta individualmente considerada não foi capaz de produzir o resultado morte, por ausência de causalidade; mesmo porque, abstraindo-se mentalmente a conduta de " $\underline{Z}$ ” ou de " $\underline{K}$ ”, o resultado teria ocorrido como ocorreu ${ }^{42}$.

O mesmo problema causal pode ser encontrado, embora de modo um pouco mais sofisticado, no ambiente corporativo, especificamente em matéria de decisões proferidas em órgãos colegiados que geram violações ao ordenamento jurídico ${ }^{43}$ : o

\footnotetext{
${ }^{39}$ FERRÉ OLIVÉ, Juan Carlos; ÁNGEL NÚÑEZ PAZ, Miguel; OLIVEIRA, William Terra de; BRITO, Alexis Couto de. Direito penal brasileiro: parte geral, princípios fundamentais e sistema, cit., p. 270.

${ }^{40}$ FIANDACA, Giovanni; MUSCO, Enzo. Derecho penal: parte general. Bogotá: Editorial Temis, 2006. p. 238.

${ }^{41}$ Exemplo retirado de Giovanni Fiandaca e Enzo Musco, Derecho penal: parte general, cit., p. 234.

${ }^{42}$ Id. Ibid., p. 238.

${ }^{43}$ ROXIN, Claus. Funcionalismo e imputação objetiva no direito penal, cit., p. 287. Claus Roxin, a propósito, não vislumbra grande diferença entre as decisões tomadas em órgãos colegiados e aquela atinente ao depósito de substância venenosa no copo do desafeto "W". Como no caso do veneno, no órgão colegiado da companhia, cada voto, tomado individualmente, não pode ser considerado causa do resultado, mas certamente o será quando verificado em conjunto com os demais votos, de sorte que aos conselheiros não socorre o argumento de que não deram causa ao resultado.
} 
Conselho de Administração da instituição financeira " $\underline{P S M}$ ", por exemplo, composto de 9 (nove) membros, delibera, por ampla maioria de votos (7 votos contra 2), aprovar habitualmente vultosos empréstimos a uma pessoa jurídica em situação econômica precária, pré-falimentar, sem exigir, em contrapartida, garantias suficientes para a quitação da operação, colocando, com esse proceder, a estabilidade e a higidez da " $\underline{P S M}$ " em patente risco de quebra. Segundo o estatuto da "PSM", a aprovação de operações financeiras de grande porte depende de maioria simples nas votações, ou seja, pelo menos 5 (cinco) votos.

Parece inegável que a conduta praticada pelos sete membros do Conselho de Administração amolda-se, consoante tem decidido a jurisprudência brasileira ${ }^{44}$, ao crime de gestão temerária de instituição financeira, previsto no artigo $4^{\circ}$, $\S$ único, da Lei n. ${ }^{\circ}$ 7.492/1986. Se aplicarmos a conditio sine qua non e retirarmos mentalmente o voto de cada um dos conselheiros, pelo menos dois deles poderiam objetar que, independentemente de seus votos, o resultado (empréstimo ruinoso) teria ocorrido da mesma maneira e, assim, não haveria espaço para a responsabilização penal.

Idêntica e não menos embaraçosa situação se observa nas manifestações em órgãos colegiados pelo prisma dos votos divergentes, isto é, daqueles conselheiros que, no citado exemplo, votaram contra a aprovação da operação de empréstimo. Neste caso, aponta Juarez Tavares que a aplicação da teoria da equivalência das condições gera um notório "impasse" 45 , pois se fincarmos a causa do crime de gestão temerária na resolução do conselho, o resultado permanece, gerando-se, assim, uma patente injustiça de conteúdo material: a responsabilização do conselheiro que votou contra o desastrado empréstimo.

Para a resolução desse impasse, Tavares explica que deve ser levada em consideração a natureza e a qualidade da condição, haja vista a existência de posições favoráveis e de posições divergentes no órgão colegiado da companhia, montando-se, em consequência, dois fluxos causais diferentes, o primeiro composto de votos favoráveis e o

\footnotetext{
${ }^{44}$ Tribunal Regional Federal da $1^{\text {a }}$ Região: ACR 41639; ACR 200035000074473; Tribunal Regional Federal da $2^{\text {a }}$ Região: ACR 9098; ACR 5580; ACR 4707 e Tribunal Regional Federal da $3^{\text {a }}$ Região: ACR 34144. No Superior Tribunal de Justiça: HC 56.800.

${ }^{45}$ TAVARES, Juarez. Direito penal da negligência: uma contribuição à teoria do crime culposo. 2. ed. Rio de Janeiro: Lumen Juris, 2003. p. 305.
} 
segundo composto de votos contrários ${ }^{46}$, resolvendo-se, então, o problema nos seguintes termos: "eliminadas as condições favoráveis (daqueles que votaram a favor), o resultado será também excluído; eliminada, por sua vez, a condição desfavorável (daquele que votou contra), o resultado permanece. Quer dizer, as condições favoráveis (dos que votaram a favor da resolução) foram causa do resultado, a outra desfavorável, não o foi. Esta é a única maneira de poder fazer da relação de causalidade um processo de demonstração racional" ${ }^{\prime 47}$.

Os cursos causais não verificáveis, a seu turno, implementar-se-ão naquelas hipóteses nas quais não é possível determinar, com precisão, o fator que ensejou o resultado, embora o nexo de causalidade seja incontestável do ponto de vista físico. Em hipóteses que tais, observam Jescheck e Weigend que existe uma relação natural entre a ação e o resultado produzido que, pelo conhecimento científico contemporâneo, pode ser verificada como altamente provável, embora não possa ser comprovada de modo absoluto $^{48}$. Jescheck e Weigend, entretanto, advertem que essa situação não pode ser confundida com aquela em que a relação de causalidade se afigura nebulosa justamente em razão de inexistir prova acerca de uma "lei causal" que indique claramente a relação entre a ação e o resultado e que, por isso, "obliga a fundamentar dicha conexión únicamente en que no existe otro motivo evidente que explique el acaecimiento del resultado típico"49.

Em verdade, Jescheck parte do pressuposto, originariamente desenvolvido por Engisch, que apenas existirá relação de causalidade quando verificada uma condição conforme uma $l e i^{50}$. Como explica Claus Roxin, isso significa que os nexos causais "quando duvidosos, jamais podem ser provados através de meras fórmulas, mas unicamente por meio de métodos exatos das ciências naturais (especialmente a experimentação). Naquelas hipóteses, contudo, em que a causalidade não é duvidosa (como no caso do fuzilamento e do veneno), a fórmula da condição conforme uma lei deixa isso transparecer de modo bem claro, não levando o observador a erro" ${ }^{\text {.51. }}$.

\footnotetext{
${ }^{46}$ TAVARES, Juarez. Direito penal da negligência: uma contribuição à teoria do crime culposo, cit., p. 306-307.

${ }^{47}$ Id. Ibid., p. 307.

${ }^{48}$ JESCHECK, Hans-Henrich; WEIGEND, Thomas. Tratado de derecho penal: parte general, cit., p. 303.

${ }^{49}$ Id. Ibid., p. 303-304.

${ }^{50}$ ROXIN, Claus. Funcionalismo e imputação objetiva no direito penal, cit., p. 280.

${ }^{51}$ Id. Ibid., p. 280-281.
} 
Em crítica semelhante, Juarez Cirino dos Santos expõe que a teoria da equivalência das condições afigura-se insuficiente para o descobrimento da causalidade em

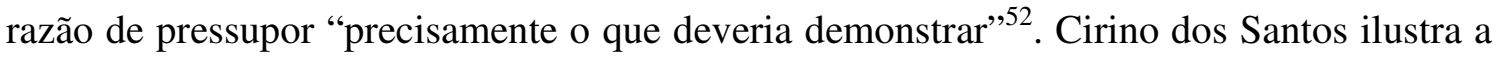
crítica nos seguintes termos: "para saber, por exemplo, se o calmante Contergan (ou Talidomida), tomado durante a gravidez, teria causado deformações no feto, seria inútil excluir hipoteticamente a ingestão do medicamento, e perguntar se o resultado, então, desapareceria; para responder essa pergunta seria preciso saber se o medicamento é causador de deformações no feto e, se já existe esse conhecimento, a pergunta seria ociosa: assim, a fórmula da exclusão hipotética parece pressupor o que somente através dela deveria ser pesquisado",53.

Finalmente, nos cursos alternativos e hipotéticos, considerados por Ferré Olivé, Núñez Paz, Terra e Couto de Brito como sendo aqueles "teoricamente mais confusos" ${ }^{\text {} 54}$, existe um resultado derivado de uma sobreposição de causas que, se extraídas do desdobramento causal, haveriam de produzir o mesmo resultado de igual maneira e simultaneamente. Imagine-se o caso do sujeito " $\underline{X}$ " que, para matar o desafeto " $\underline{Y}$ ", deposita na casa deste significativa quantidade de explosivos, com a qual consegue, ao detonar a carga, o seu intento (resultado) criminoso, mas que, posteriormente, descobre-se que o mesmo resultado adviria de um incêndio de grandes proporções que se originou nas cercanias da casa de " $\underline{X}$ " por causas naturais quase contemporâneas a tal fato. Se eliminarmos mentalmente a causa carga de explosivos pelo costumeiro método de eliminação de hipotética de Thyrén, o incêndio que resultou na destruição da casa de " $\underline{\text { }}$ " não deixaria de existir. Não obstante, não se pode negar imputação penal para " $\underline{X}$ ” e, por consequência, a atribuição de responsabilidade penal.

Em ordem a corrigir as inegáveis imperfeições que recaem na relação de causalidade em razão da constante aplicação da teoria da conditio sine qua non e seu correspondente - e deletério - efeito de regressar ao infinito, o legislador brasileiro fez uma

\footnotetext{
${ }^{52}$ SANTOS, Juarez Cirino dos. Direito penal: parte geral, cit., p. 117. Com a mesma crítica: DIAS, Jorge de Figueiredo. Direito penal: parte geral: questões fundamentais: a doutrina geral do crime, cit., t. 1, p. 325.

${ }^{53}$ SANTOS, Juarez Cirino dos. Direito penal: parte geral, cit., p. 117.

${ }^{54}$ FERRÉ OLIVÉ, Juan Carlos; ÁNGEL NÚÑEZ PAZ, Miguel; OLIVEIRA, William Terra de; BRITO, Alexis Couto de. Direito penal brasileiro: parte geral, princípios fundamentais e sistema, cit., p. 271.
} 
concessão à teoria da causalidade adequada no artigo $13, \S 1^{\circ}$, do Código Penal ${ }^{55}$, desenvolvida por Von Bar e Von Kries, e que consiste, em linhas gerais, na consideração da causa somente quando a conduta se afigurar concretamente adequada ou idônea para a produção do resultado, diferenciando-se, assim, os processos causais que efetivamente foram visados pelo agente daqueles que representam fruto exclusivo de causas fortuitas ou acidentais ${ }^{56}$.

Destaca Juarez Cirino dos Santos que a adequação da condição para a produção do resultado será alcançada segundo uma prognose objetiva superior, ou seja, "do ponto de vista de um observador inteligente colocado antes do fato, com os conhecimentos gerais de um homem informado pertencente ao círculo social do autor, além dos conhecimentos especiais deste" ${ }^{\mathrm{5}}$.

Embora comumente analisada pela doutrina em conjunto com a teoria da equivalência dos antecedentes causais, a teoria da causalidade adequada não consubstancia, como nota Claus Roxin, uma teoria de causalidade, mas uma teoria de imputação penal, que antes de representar uma alternativa ao postulado da conditio sine qua non, serve-lhe de complemento ${ }^{58}$. De fato, ao introduzir o elemento adequado ou idôneo na constatação do desdobramento do processo causal, a teoria da adequação enseja uma análise de visível carga axiológica pelo intérprete e aplicador da norma, a ponto de a ela ter sido reservado, como recorda Luís Greco, um lugar entre os topoi que compõem a imputação objetiva ${ }^{59}$.

A despeito da adoção, pelo legislador brasileiro e pela doutrina, das teorias da equivalência dos antecedentes causais e da causalidade adequada para a resolução dos problemas causais relacionados aos crimes de resultado, não se pode deixar de mencionar que a doutrina brasileira também costuma recorrer a um filtro subjetivo, vinculado, tradicionalmente, em razão da influência do causalismo, à ideia de culpabilidade ${ }^{60}$.

\footnotetext{
${ }^{55}$ Nesse sentido: REALE JÚNIOR, Miguel. Teoria do delito, cit., p. 180.

${ }^{56}$ BRUNO, Aníbal. Direito penal: parte geral. 5. ed. Rio de Janeiro: Forense, 2005. t. 1, p. 202.

${ }^{57}$ SANTOS, Juarez Cirino dos. Direito penal: parte geral, cit., p. 121.

${ }^{58}$ ROXIN, Claus. Funcionalismo e imputação objetiva no direito penal, cit., p. 304.

${ }^{59}$ Id. Ibid., p. 27.

${ }^{60}$ Nesse diapasão, confira-se Nélson Hungria: “Após a averiguação de um evento penalmente típico na sua objetividade, tem-se de apurar, não sòmente se foi causado por alguém, mas, também, se o agente procedeu dolosa ou culposamente. O requisito da culpabilidade é, sob o prisma jurídico-penal, um corretivo à excessiva amplitude do conceito de causa (no sentido puramente lógico)" (HUNGRIA, Nélson. Comentários ao Código Penal, cit., p. 66-67). Nesse mesmo sentido: FRAGOSO, Heleno Cláudio. Lições de direito penal: a nova parte penal. 11. ed. Rio de Janeiro: Forense, 1987. p. 168.
} 
Dessa forma, preconiza Miguel Reale Júnior que a "verificação da alteração do mundo exterior produzida pelo homem, com a causalidade de um resultado, é questão prévia, mas que não pode, todavia, deixar de se relacionar com o momento psicológico da ação, uma vez que o comportamento humano constitui um todo irredutível, cujos aspectos se inter-relacionam e se complementam. A ação relevante é a congruente com um todo típico formado por elementos subjetivos e objetivos, o que vem a ser um conceito-fonte, que estende seu significado a todas as demais construções típicas do direito penal"61.

Parece-nos, contudo, que o recurso a um elemento de natureza subjetiva na verificação da relação de causalidade, ainda que com a louvável intenção de limitá-la ou restringi-la, antes de resolver a problemática da imputação penal, complica-a ao agregar um componente que não pode ser objetivamente analisado, ou seja, somente pode ser aferido circunstancialmente ${ }^{62}$, no mais das vezes de modo intuitivo e, portanto, temerário.

Ao se pretender acertar a imputação mediante a utilização de um critério subjetivo, reforça Hans-Joachim Rudolphi, incorre-se em um duplo erro: o primeiro, porque olvida que a causação de um determinado resultado não é idônea, por si mesma, para fundamentar o injusto típico, isto é, tendo presente que o conteúdo das normas jurídicas relaciona-se somente a uma proibição ou incentivo de uma determinada ação humana, a mera causação de um resultado tipicamente antijurídico não consubstancia nenhuma ofensa a essas regras. O segundo, porque, como assentado, ao lançar mão do dolo, da culpa e da culpabilidade para corrigir problemas de causalidade, estar-se-á caminhando em terreno pantanoso, incerto, que não oferece nenhuma base sólida para excluir, sem alguma dúvida, os casos puníveis do âmbito da conduta penal ${ }^{63}$.

Nessa esteira, basta citar, para ilustrar, as infindáveis discussões acerca da prova do dolo, direto ou eventual, e a distinção, invariavelmente complexa, entre o dolo

\footnotetext{
${ }^{61}$ REALE JÚNIOR, Miguel. Instituições de direito penal: parte geral, cit., v. 1, p. 247. Não obstante, ainda segundo Reale Júnior, a "referência ao elemento subjetivo não é decorrente da necessidade de um 'corretivo à excessiva amplitude de causa', mas do fato de ser integrante da estrutura do real, o que torna obrigatória sua correlação direta com o aspecto material da ação" (Id. Ibid., p. 253).

${ }^{62} \mathrm{O}$ que significa dizer, com Hruschka, que no âmbito do dolo, os fatos que surgem relevantes para a imputação penal somente podem ser extraídos da análise global das circunstâncias externas do fato praticado (HRUSCHKA, Joachim. Imputación y derecho penal: estudios sobre la teoría de la imputación, cit., p. 155).

${ }^{63}$ RUDOLPHI, Hans-Joachim. Causalidad e imputación objetiva. Colombia: Universidad Externado de Colombia, 2006. p. 25.
} 
eventual e a culpa consciente ${ }^{64}$, ou mesmo algumas categorias de crimes que não apresentam resultado naturalístico, como é o caso dos crimes de perigo abstrato ${ }^{65}$.

Em outro dizer: não desprezamos o elemento volitivo do agente para a adequada verificação do nexo de causalidade, mas entendemos que ele deve ser relegado para um momento de análise posterior, prestigiando-se, com isso, o estudo eminentemente objetivo da imputação penal.

Sustentamos, pois, a necessidade da utilização de instrumentos normativos na relação da causalidade estabelecida, na origem, com base na - insuficiente, como adiantado - teoria da equivalência dos antecedentes causais ${ }^{66}$, de resto adotada, segundo entendimento amplamente majoritário, no artigo 13, caput, do Código Penal brasileiro ${ }^{67}$.

Para a consecução do presente trabalho, o critério normativo eleito foi o da criação de um risco juridicamente desaprovado e a subsequente concretização deste risco no resultado, ou seja, a teoria da imputação penal objetiva.

\subsection{Espécies de imputação penal}

A doutrina não elabora distinção entre modalidades de imputação penal. Não obstante, para a melhor compreensão do presente trabalho e, principalmente, para justificar e emprestar alguma coerência às suas conclusões optou-se pelo exame da atribuição de responsabilidade penal através da repartição em dois grupos: o primeiro diz

\footnotetext{
${ }^{64}$ Sobre a discussão no Direito Alemão, mas com relevantes contribuições à distinção entre o dolo e a culpa no Direito Penal brasileiro: PUPPE, Ingeborg. A distinção entre dolo e culpa. Tradução, introdução e notas de Luís Greco. Barueri-SP: Manole, 2004. p. 23.

${ }^{65}$ Sobre o tema: BAIGÚN, David. Los delitos de peligro y la prueba del dolo. Buenos Aires-Argentina: B de F, 2007. p. 35-41.

${ }^{66}$ Como assevera Jorge de Figueiredo Dias, "a relação de causalidade, embora sempre necessária, não é suficiente para se constituir em si mesma como a doutrina da imputação objectiva. Importa pois, guardando este primeiro escalão da imputação, subir agora de nível, ao patamar da valoração jurídica, para determinar em definitivo quais as exigências indispensáveis a que se perfaça uma coerente doutrina da imputação" (DIAS, Jorge de Figueiredo. Direito penal: parte geral: questões fundamentais: a doutrina geral do crime, cit., t. 1, p. 327).

${ }^{67}$ Nessa esteira: REALE JÚNIOR, Miguel. Teoria do delito, cit., p. 178-180; BITENCOURT, Cezar Roberto. Tratado de direito penal: parte geral, cit., v. 1, p. 309-310; BRUNO, Aníbal. Direito penal: parte geral, cit., t. 1, p. 208; MUÑOZ CONDE, Francisco. Teoria geral do delito, cit., p. 25, nota de rodapé n. ${ }^{\circ} 21$.
} 
respeito ao plano por intermédio do qual a imputação pode ocorrer em consideração aos requisitos do tipo penal: (i) objetiva e (ii) subjetiva ${ }^{68}$. O segundo grupo leva em consideração o(s) destinatário(s) da imputação penal, de sorte que podemos cogitar de imputação (i) individual e imputação (ii) coletiva.

\subsubsection{Imputação objetiva e imputação subjetiva}

No plano objetivo a imputação ocorre por intermédio da subsunção da conduta ao tipo penal sem a consideração do elemento subjetivo (dolo), verificando-se exclusivamente com base em critérios jurídicos, normativos, baseados, consoante sustentamos, na ideia de um risco juridicamente desaprovado e na subsequente concretização deste risco no resultado.

De outro lado, do ponto de vista subjetivo, a imputação sucede quando, uma vez assentada a imputação no patamar objetivo com esteio em critérios exclusivamente normativos, a atribuição de responsabilidade penal se faz mediante a constatação do dolo. A imputação penal tornar-se-á completa quando a conduta alcançar tanto o patamar objetivo como o plano subjetivo.

A imputação subjetiva atende, como pontua Kai Ambos, a uma dupla exigência, ambas indeclináveis na atual conjuntura do Direito Penal: uma atinente ao princípio da culpabilidade e outra relacionada aos próprios pressupostos da responsabilidade individual ${ }^{69}$. Entretanto, em face das dificuldades relacionadas à

\footnotetext{
${ }^{68}$ Ressalve-se, todavia, que a análise empreendida pressupõe a diferenciação conceitual entre imputação objetiva e a teoria da imputação objetiva, em ordem a evitar confusões terminológicas. Dessa forma, o termo imputação objetiva será reservado para designar a atribuição de determinado fato criminoso a alguém com base em critérios ou elementos objetivos, enquanto o termo teoria da imputação objetiva será manejado para indicar a orientação dogmática que preconiza, com base na criação de risco desaprovado e a verificação deste risco no resultado, a imputação de um crime a alguém. Nesse mesmo sentido: Luís Greco, para quem a teoria da imputação objetiva "enuncia o conjunto de pressupostos que fazem de uma causação uma causação objetivamente típica; e estes pressupostos são a criação de um risco juridicamente desaprovado e a realização deste risco no resultado" (GRECO, Luís. Um panorama da teoria da imputação objetiva. 3. ed. São Paulo: Ed. Revista dos Tribunais, 2013. p. 22).

${ }^{69}$ AMBOS, Kai. A parte geral do direito penal internacional: bases para uma elaboração dogmática. Ed. brasileira refor. e atual. São Paulo: Ed. Revista dos Tribunais, 2008. p. 83.
} 
demonstração do móvel anímico do agente, notadamente no campo probatório, a imputação de perfil objetivo serve, repita-se, como um filtro ou mesmo um segundo grau de checagem mais seguro de análise, norteado por critérios exclusivamente jurídicos ${ }^{70}$.

\subsubsection{Imputação individual e imputação coletiva}

A imputação individual é aquela que incide sobre determinada pessoa em razão da prática de um fato criminoso. É, em outros termos, a modalidade típica de atribuição de responsabilidade penal que se concretiza em face de dado indivíduo em razão de um dado delito por ele cometido. A imputação individual é própria dos crimes unissubjetivos, ou seja, perpetrados isoladamente pelo agente. Havendo eventual intervenção de outra(s) pessoa(s) na conduta delituosa a imputação não deixará de ser individual, mas a atribuição de responsabilidade penal valer-se-á dos critérios normativos inerentes ao concurso de pessoas.

A imputação coletiva, a seu turno, é aquela cuja imputação do resultado criminoso recai sobre um grupo de pessoas, sem que seja possível estabelecer, com precisão, os diversos graus de contribuição de cada sujeito no evento delituoso ${ }^{71}$. A imputação coletiva se perfaz, portanto, em ambientes coletivos e exige, para a sua concretização, um elemento adicional que a distingue da imputação individual: o coletivo.

Neste caso, a atribuição de responsabilidade penal ocorre em razão do fato do crime ser perpetrado por intermédio de um ente coletivo ao qual o sujeito voluntariamente aderiu. A imputação coletiva tem encontrado destaque prático no âmbito dos chamados crimes de Estado, como é o caso do genocídio e dos crimes de guerra ${ }^{72}$, mas

\footnotetext{
${ }^{70}$ Embora não se ignore, a bem da verdade, que nenhuma categoria de imputação penal possa ser exclusivamente objetiva. Em face da consideração que o crime decorre necessariamente de um comportamento humano em alguma medida o elemento subjetivo deverá ser sopesado.

${ }^{71}$ HASSEMER, Winfried. Persona, mundo y responsabilidad: bases para una teoría de la imputación en derecho penal. Bogotá: Editorial Temis, 1999. p. 99.

${ }^{72}$ AMBOS, Kai. Principios e imputación en el derecho penal internacional. Barcelona: Atelier, 2008. p. 18. Não obstante prevaleça a responsabilidade de natureza individual no Direito Penal Internacional, até por força do que determinam os regulamentos internacionais, como, por exemplo, o artigo 25 do Estatuto de Roma (Decreto n. ${ }^{\circ}$ 4.388/2002): De acordo com o presente Estatuto, o Tribunal será competente para julgar
} 
também tem manifesta utilidade, como recorda Laura Zúñiga, no contexto dos crimes cometidos por intermédio de estruturas empresariais e organizações criminais ${ }^{73}$.

Assim, além da imputação individual, centrada no liame existente entre o fato cometido e o resultado produzido, a entidade coletiva também pode dar azo à atribuição de responsabilidade penal através dos parâmetros dogmáticos existentes ${ }^{74}$.

Kai Ambos observa que, nos casos de imputação coletiva, é possível vislumbrar um modelo de dupla imputação, o que significa dizer que as esferas de imputação penal individual e coletiva não operam em um plano paralelo, mas em um ambiente plano inter-relacionado ${ }^{75}$. Segundo Ambos, em termos de imputação coletiva é importante a compreensão prévia de uma dupla perspectiva: em primeiro lugar, a perspectiva coletiva concentra-se no elemento contextual pertencente a todos os participantes, ou seja, a situação criminosa que represente um objetivo supraindividual. Em segundo lugar, que este contexto pode ser cobrado como um todo ou em parte em relação

as pessoas físicas. 2. Quem cometer um crime da competência do Tribunal será considerado individualmente responsável e poderá ser punido de acordo com o presente Estatuto. 3. Nos termos do presente Estatuto, será considerado criminalmente responsável e poderá ser punido pela prática de um crime da competência do Tribunal quem: a) Cometer esse crime individualmente ou em conjunto ou por intermédio de outrem, quer essa pessoa seja, ou não, criminalmente responsável; b) Ordenar, solicitar ou instigar à prática desse crime, sob forma consumada ou sob a forma de tentativa; c) Com o propósito de facilitar a prática desse crime, for cúmplice ou encobridor, ou colaborar de algum modo na prática ou na tentativa de prática do crime, nomeadamente pelo fornecimento dos meios para a sua prática; d) Contribuir de alguma outra forma para a prática ou tentativa de prática do crime por um grupo de pessoas que tenha um objetivo comum. Esta contribuição deverá ser intencional e ocorrer, conforme o caso: i) Com o propósito de levar a cabo a atividade ou o objetivo criminal do grupo, quando um ou outro impliquem a prática de um crime da competência do Tribunal; ou ii) Com o conhecimento da intenção do grupo de cometer o crime; e) No caso de crime de genocídio, incitar, direta e publicamente, à sua prática; f) Tentar cometer o crime mediante atos que contribuam substancialmente para a sua execução, ainda que não se venha a consumar devido a circunstâncias alheias à sua vontade. Porém, quem desistir da prática do crime, ou impedir de outra forma que este se consuma, não poderá ser punido em conformidade com o presente Estatuto pela tentativa, se renunciar total e voluntariamente ao propósito delituoso. 4. O disposto no presente Estatuto sobre a responsabilidade criminal das pessoas físicas em nada afetará a responsabilidade do Estado, de acordo com o direito internacional.

${ }^{73}$ ZÚÑIGA RODRÍGUEZ Laura. Criminalidad organizada y sistema de derecho penal: contribución a la determinación del injusto penal de organización criminal. Granada: Editorial Comares, 2009. p. 252.

${ }^{74}$ Hassemer observa, em tom crítico, que uma imputação dirigida a um grupo de pessoas e que se diz justa e adequada, mas que não distingue os indivíduos que compõem o coletivo, constitui uma justificação demasiada débil das consequências penais que afetam a pessoa em particular (HASSEMER, Winfried. Persona, mundo y responsabilidad: bases para una teoría de la imputación en derecho penal, cit., p. 100).

${ }^{75}$ AMBOS, Kai. Principios e imputación en el derecho penal internacional, cit., p. 19. 
aos participantes considerados individualmente, usando regras de alocação de responsabilidade que se estabelecem para a elaboração da imputação ${ }^{76}$.

A pertinência prática da imputação coletiva exsurge, sem dúvida, nos denominados delitos de organização, vale dizer, naquelas infrações relacionadas à existência de uma associação penalmente ilícita ${ }^{77}$. Nesse passo, não se pode deixar de mencionar, ainda que panoramicamente, as diversas críticas incidentes sobre a consideração, pelo Direito Penal, de manifestações coletivas criminalizadas pelo legislador com o escopo de proteger bens jurídicos pouco palpáveis ou mesmo fictícios, como a paz pública $^{78}$, ou que antecipam indevidamente a consideração da conduta a momento anterior ao início dos atos de execução ${ }^{79}$ ou mesmo que, o que nos parece mais grave, criam um ambiente propício para a implementação de uma responsabilização "por adesão", para usar a expressão de Jesús María Silva Sánchez ${ }^{80}$.

Sob esse último enfoque Silva Sánchez critica o que ele chama de "modelo de transferência de imputação individual de um fenômeno coletivo" ${ }^{, 81}$. No caso dos delitos de organização, pontua Silva Sánchez, pode ocorrer uma transferência de responsabilidade penal para cada um dos membros pelo simples fato de "ser" ou "pertencer" à organização, independentemente de qualquer consideração mais detalhada acerca do efetivo ou real conhecimento, por parte do membro, do perigo que ela (organização) representa ${ }^{82}$.

A solução proposta por Silva Sánchez para ajustar a imputação dos membros de uma organização reside na utilização de um "modelo de imputação por fato próprio" cuja essência parte da ideia de que cada indivíduo somente pode ser

\footnotetext{
${ }^{76}$ AMBOS, Kai. Principios e imputación en el derecho penal internacional, cit., p. 19.

${ }^{77}$ CANCIO MELIÁ, Manuel; SILVA SÁNCHEZ, Jesús María. Delitos de organización. Buenos Aires: Editorial B de F, 2008. p. 27.

${ }^{78}$ ROXIN, Claus. Estudos de direito penal. Tradução de Luís Greco. Rio de Janeiro: Renovar, 2006. p. 48-52.

${ }^{79}$ PITOMBO, Antônio Sérgio Altieri de Moraes. Organização criminosa, nova perspectiva do tipo legal. São Paulo: Ed. Revista dos Tribunais, 2009. p. 81-82.

${ }^{80}$ CANCIO MELIÁ, Manuel; SILVA SÁNCHEZ, Jesús María. Delitos de organización, cit., p. 102.

${ }^{81}$ Id. Ibid., p. 101.

${ }^{82}$ Id. Ibid., p. 103. Deveras, para Jesús María Silva Sánchez a considerar esse modelo de transferência da imputação, sequer será necessário procurar alguma conduta, isto é, que sejam membros ativos, haja vista que o simples reconhecimento da condição de componente equipar-se-ia à declaração de estar disposto à perpetração dos delitos-fim da organização, gerando-se, com isso, atribuição de responsabilidade (Id. Ibid., p. 104). Tal crítica, por sinal, soa extremamente atual e pertinente em face da redação do citado artigo $2^{\circ}$ da Lei n. ${ }^{\circ}$ 12.850/2013, que tipifica o "integrar, pessoalmente ou por interposta pessoa, organização criminosa".
} 
responsabilizado por aquilo que produziu por seu próprio comportamento, ou seja, não se cogita de transferência de responsabilidade ao membro pelo perigo da organização, mas se lhe imputa apenas a comissão de delitos que ele favoreceu, mediante dolo ${ }^{83}$.

O padrão de imputação sugerido por Silva Sánchez possui o mérito de obstar a responsabilidade penal objetiva e prestigiar o significado institucional da organização, tomada como ente autônomo ou instituição portadora do sistema de condutas favorecedoras concretamente dos crimes-fim levados a efeito por seus componentes, além de adaptar as regras de imputação penal à realidade inexorável das organizações ${ }^{84}$.

\subsection{A teoria da imputação objetiva}

\subsubsection{Introdução}

Conforme apontado, comungamos da ideia que a imputação penal representa uma categoria essencialmente normativa que deve ser realizada segundo as balizas próprias da dogmática jurídico-penal, isto é, a atribuição de um resultado com conteúdo penal a alguém não pode ser analisada ao largo de critérios normativos.

Assim, em conformidade com Juarez Cirino dos $\operatorname{Santos}^{85}$, partimos do pressuposto que a atribuição do tipo objetivo pressupõe dois momentos essenciais, um de natureza ôntica, verificado pela lógica da determinação causal e outro, atrelado à imputação do resultado, de natureza axiológica, fundado no critério do risco desaprovado e a sua correspondente verificação no resultado.

\footnotetext{
${ }^{83}$ CANCIO MELIÁ, Manuel; SILVA SÁNCHEZ, Jesús María. Delitos de organización, cit., p. 105 e p. 109. ${ }^{84}$ Id Ibid., p. 109 e p. 111.

${ }^{85}$ SANTOS, Juarez Cirino dos. Direito penal: parte geral, cit., p. 114. Para Cirino dos Santos "não parece possível confundir questões de causalidade e questões de imputação do resultado: a distinção entre causação do resultado (processos naturais de determinação causal) e imputação do resultado (processos valorativos de atribuição típica) está incorporada ao sistema conceitual da dogmática penal contemporânea" (Id. Ibid., p. 114).
} 
A teoria da imputação objetiva, desenvolvida originariamente, no Direito Civil, por Karl Larenz (1927), e posteriormente transportada, para o Direito Penal, por obra de Richard Honig (1930) ${ }^{86}$, teve o patente mérito de reconhecer a insuficiência do processo causal natural como móvel para a imputação penal e redimensionar o tipo penal, colocando o elemento subjetivo e a finalidade do agente em um segundo patamar (imputação subjetiva $)^{87}$. Em consequência, a teoria da imputação objetiva forneceu fundamentos razoáveis para uma série de fenômenos penais que, até o seu advento, mostravam-se, para a perplexidade do aplicador da norma, injustificáveis, inexplicáveis e, portanto, materialmente injustos. Subjacente a essa primeira constatação, a teoria também merece prestígio por desenvolver um fator concreto de limitação da responsabilidade penal ${ }^{88}$.

Aliás, poder-se-ia mesmo dizer que, pela aplicação dos critérios comumente adotados (criação de risco e verificação do risco no resultado), mais do que limitar, a teoria da imputação objetiva proporciona uma real delimitação de responsabilidade, incluindo no raio do tipo penal quem tem responsabilidade e excluindo quem não a tem ${ }^{89}$.

\subsubsection{A teoria da imputação objetiva segundo Claus Roxin}

Após diversas tentativas ${ }^{90}$, a teoria da imputação objetiva foi retomada por Claus Roxin, ao ensejo de um artigo escrito em homenagem aos 70 anos de Richard Honig, denominado Reflexões sobre a problemática da imputação em Direito Penal.

\footnotetext{
${ }^{86}$ ROXIN, Claus. Reflexões sobre a problemática na imputação em direito penal. In: Problemas fundamentais de direito penal. Trad. Ana Paula dos Santos Luis Natscherad. 3. ed. Lisboa: Vega, 2004. p. 145-148.

${ }^{87}$ GRECO, Luís. Um panorama da teoria da imputação objetiva. 2. ed. Rio de Janeiro: Lumen Júris, 2007. p. 9.

${ }^{88}$ CAMARGO, Antonio Luís Chaves de. Imputação objetiva e direito penal brasileiro. 1. ed. 2. tir. São Paulo: Cultural Paulista, 2002. p. 70.

${ }^{89}$ Eugenio Raúl Zaffaroni e José Henrique Pierangeli criticam, porém, a concepção desenvolvida pelos adeptos da teoria da imputação objetiva, nomeadamente Claus Roxin e Günther Jakobs, sob o principal argumento que dela se extraem várias consequências complicadas, "a ponto de a teorização perder sua coerência e cair no casuísmo jurídico" (ZAFFARONI, Eugenio Raúl; PIERANGELI, José Henrique. Manual de direito penal brasileiro: parte geral, cit., p. 474).

${ }^{90}$ GRECO, Luís. Introdução. In: ROXIN, Claus. Funcionalismo e imputação objetiva no direito penal, cit., p. 47-56.
} 
Nesta ocasião, Roxin ancorou o eixo fundamental da teoria da imputação objetiva na ideia (normativa) de risco juridicamente relevante a um bem jurídico ${ }^{91}$, daí derivando as seguintes consequências, aqui sumariadas ${ }^{92}$ : (i) a diminuição do risco em relação ao bem jurídico protegido não enseja imputação; (ii) quando se cogita de criação ou não criação de um risco juridicamente relevante, a análise do elemento subjetivo, nos crimes dolosos, e do elemento normativo (previsibilidade objetiva), nos culposos, exsurge secundária; (iii) o aumento ou falta de aumento do risco permitido, o que significa dizer, com o próprio Roxin que, quando "o legislador permite que, à semelhança do que sucede em outras manifestações da vida moderna, na actividade de estabelecimentos perigosos e em outros casos de utilidade social preponderante, se corra um risco até certo limite, apenas poderá haver imputação se a conduta do autor significar um aumento do risco permitido. Se tal situação se configura como tal, tem de imputar-se o resultado ao agente, ainda que este tenha actuado de forma irrepreensível"93; (iv) a esfera de proteção da norma como critério de imputação: os resultados que não se submetem ao âmbito de proteção da norma de cuidado não podem ser imputáveis a quem lhes deu causa. Neste último caso, mais recentemente designados de alcance do tipo ${ }^{94}$, Roxin trata daquelas situações em que, para além do autor da conduta, contribuem eficazmente para a produção do resultado outras pessoas, como, por exemplo, a vítima ou mesmo terceiros ${ }^{95}$. A propósito, como destaca Luís Greco, é justamente no aspecto do alcance do tipo que Claus Roxin se distingue dos demais autores alemães que, como ele, adotam a teoria da imputação objetiva, mas que a restringem aos conceitos de criação de risco e sua subsequente realização, haja vista que Roxin exige uma espécie de "terceiro plano" para a realização da atribuição de responsabilidade penal ${ }^{96}$.

\footnotetext{
${ }^{91}$ ROXIN, Claus. Reflexões sobre a problemática na imputação em direito penal, cit., p. 148.

${ }^{92}$ Id. Ibid., p. 149-161.

${ }^{93}$ Id. ibid., p. 152.

${ }^{94}$ GRECO, Luís. Introdução. In: ROXIN, Claus. Funcionalismo e imputação objetiva no direito penal, cit., p. 116.

${ }^{95}$ Id. Ibid., p. 116-117. É nesse ponto que Roxin trata das questões relacionadas às hipóteses de (i) contribuição a uma autocolocação em perigo dolosa; de (ii) heterocolocação em perigo consentida; e de (iii) atribuição ao âmbito de responsabilidade alheio (Funcionalismo e imputação objetiva no direito penal, cit., p. 353-375).

${ }^{96}$ GRECO, Luís. Introdução. In: ROXIN, Claus. Funcionalismo e imputação objetiva no direito penal, cit., p. 116.
} 
O Direito Penal, acrescenta Luís Greco, deve se ocupar apenas das ações perigosas a bens jurídicos e "proibir ações não perigosas é proibir por proibir, é limitar a liberdade sem correspondente ganho social" ${ }^{, 97}$.

Sob esse contexto, a ação deverá ser considerada perigosa mediante a utilização do critério da prognose póstuma objetiva, ou seja, um juízo formulado antecipadamente (ex ante) em face dos dados conhecidos no momento da perpetração da ação, de acordo com a concepção de um homem prudente, diligente.

Assim, "uma ação será perigosa ou criadora de risco se o juiz, levando em conta os fatos conhecidos por um homem prudente no momento da prática da ação, diria que esta gera uma possibilidade real de lesão a determinado bem jurídico"98.

A concepção básica que permeia toda a teoria da imputação desenvolvida por Claus Roxin lastreia-se no fato de que a missão do Direito Penal é a proteção de bens jurídicos ${ }^{99}$. Nesse sentido, Roxin defende que a função do Direito Penal "consiste em garantir a seus cidadãos uma existência pacífica, livre e socialmente segura, sempre e quando estas metas não possam ser alcançadas com outras medidas político-sociais que afetem em menor medida a liberdade dos cidadãos" ${ }^{\text {,100. }}$

Assim, para a realização adequada da imputação objetiva, apenas aquelas condutas consideradas objetivamente perigosas aos bens jurídicos penalmente protegidos é que merecerão a atenção do aplicador da norma penal incriminadora ${ }^{101}$.

\footnotetext{
${ }^{97}$ GRECO, Luís. Introdução. In: ROXIN, Claus. Funcionalismo e imputação objetiva no direito penal, cit., p. 24. ${ }^{98}$ Id. Ibid., p. 26.

${ }^{99}$ ROXIN, Claus. Derecho penal: parte general: fundamentos. La estructura de la teoría del delito, cit., t. $1, \S$ 38. Sobre a proteção de bens jurídicos pelo Direito Penal, confira-se, ainda, como obra fundamental: HEFENDEHL, Roland (Ed.). La teoría del bien jurídico, ¿Fundamento de legitimación del derecho penal o juego de abalorios dogmático? Trad. Rafael Alcácer Girao. Madrid: Marcial Pons, Ediciones Jurídicas y Sociales S.A., 2007 e MÜSSIG, Bernd. Desmaterialización del bien jurídico y de la política criminal: sobre las perspectivas y los fundamentos de una teoría del bien jurídico crítica hacia el sistema. Traduccion de Manuel Cancio Meliá e Enrique Peñaranda Ramos. Bogotá, Colombia: Universidad Externado de Colombia, Centro de Investigación en Filosofía y Derecho, 2001.

${ }^{100}$ ROXIN, Claus. A proteção de bens jurídicos como função do direito penal. Org. e trad. André Luís Callegari, Nereu José Giacomolli. Porto Alegre: Livr. do Advogado Ed., 2006. p. 16.

${ }^{101}$ Com efeito, para Claus Roxin, a "imputação objetiva, ao considerar a ação típica uma realização de um risco não permitido dentro do alcance do tipo, estrutura o ilícito à luz da função do direito penal. Esta teoria utiliza-se de valorações constitutivas da ação típica (risco não permitido, alcance do tipo), abstraindo de suas variadas manifestações ônticas. Afinal, não se pode caracterizar o ilícito penal através de categorias como a causalidade ou a finalidade. O ilícito nem sempre é realizado final ou causalmente, como o provam os crimes omissivos" (ROXIN, Claus. Estudos de direito penal, cit., p. 78-79).
} 
Daí a conclusão de Luís Greco no sentido de que a "idéia do risco, centro de toda a moderna teoria da imputação objetiva, fundamenta-se, desta forma, no fato de que o Direito Penal, para proteger bens jurídicos e cumprir sua função preventiva, só pode proibir ações ex ante perigosas" ${ }^{102}$.

\subsubsection{A teoria da imputação objetiva segundo Günther Jakobs}

A teoria da imputação objetiva concebida por Günther Jakobs parte da ideia, de resto central no sistema penal por ele desenvolvido, que cada pessoa ostenta um papel na sociedade. Sob esse contexto, Jakobs defende que haverá a imputação de um comportamento na constatação de algum desvio ou frustração à expectativa a que se refere o portador do rol $^{103}$. Jakobs explica que, ao se atribuir encargos às pessoas em sociedade, criam-se padrões pessoais, ou seja, papéis que devem ser cumpridos, possibilitando-se, com isso, uma orientação calcada em padrões gerais. A atuação em conformidade com o papel social não pode acarretar responsabilidade; se houve resultado a despeito da conformidade com o papel atribuído ao sujeito em sociedade, ele somente pode ser obra de uma fatalidade ou de um acidente.

Essa construção tem a vantagem, segundo aponta Jakobs, de afastar a necessidade de perquirir sobre as características individuais de cada sujeito que atua em sociedade e, assim, proporcionar contatos anônimos em alto grau, os quais são necessários para o desenvolvimento das relações econômicas e sociais ${ }^{104}$. Para Jakobs, "não são decisivas as capacidades de quem atua, mas as capacidades do portador de um papel, referindo-se a denominação papel a um sistema de posições definidas de modo normativo, ocupado por indivíduos intercambiáveis; trata-se, portanto, de uma instituição que se orienta com base nas pessoas" 105 .

\footnotetext{
${ }^{102}$ GRECO, Luís. Introdução. In: ROXIN, Claus. Funcionalismo e imputação objetiva no direito penal, cit., p. 82.

${ }^{103}$ JAKOBS, Günther. La imputación objetiva en derecho penal, cit., p. 22.

${ }^{104}$ Id. Ibid., p. 21.

${ }^{105}$ JAKOBS, Günther. A imputação objetiva no direito penal. Tradução André Luís Callegari. 2. ed. São Paulo: Ed. Revista dos Tribunais, 2007. p. 22.
} 
No sistema idealizado por Günther Jakobs, a pena assume papel central, visto que destinada à manutenção da expectativa normativa. Ela revela, com efeito, uma oposição à violação normativa provocada pela conduta do agente e seus principais destinatários não são os indivíduos potencialmente criminosos, mas todos os membros da sociedade, notadamente porque são justamente estes (membros da sociedade) as potenciais vítimas da quebra de expectativa normativa causada pela conduta delituosa ${ }^{106}$.

Ninguém, salienta Günther Jakobs, pode abrir mão das interações sociais, "todos precisam saber o que podem esperar das interações"107. A pena, que ocupa o mesmo patamar e significado da própria violação da norma, tem, dessa forma, o dever de preservála, impedir que a expectativa normativa reste anulada pela sua defraudação ${ }^{108}$.

Sob esse contexto, Jakobs aponta que a aplicação da pena contempla um triplo efeito: (i) exercita a confiança normativa, porquanto destinada a todos os membros que convivem em sociedade; (ii) exercita a fidelidade jurídica, pois impõe ao violador da norma "consequências dispendiosas", incutindo a ideia, para os demais membros da sociedade, que a violação da norma revela um comportamento inadequado; (iii) exercita a aceitação das consequências, visto que põe em relevo a "conexão entre comportamento e obrigação de arcar com os custos, ainda que a norma seja transgredida não obstante o que foi aprendido" $" 109$.

O edifício teórico erguido por Jakobs deriva do postulado de que a missão fundamental do Direito Penal não é a proteção de bens jurídicos, como defendido por Claus Roxin, mas, diante da constatação que a função do Direito serve à estruturação das relações travadas entre as pessoas, o que se tutela é a vigência da norma, a expectativa que não se produzam ataques a bens ${ }^{110}$. Segundo as palavras do próprio Jakobs, bem jurídico-

\footnotetext{
${ }^{106}$ PEÑARANDA RAMOS, Enrique; SUÁREZ GONZÁLEZ, Carlos; CANCIO MELIÁ, Manuel. Um novo sistema do direito penal: considerações sobre a teoria de Günther Jakobs. Organização e tradução de André Luís Callegari e Nereu José Giacomolli. Barueri-SP: Manole, 2003. p. 5.

${ }^{107}$ JAKOBS, Günther. Tratado de direito penal: teoria do injusto penal e culpabilidade. Belo Horizonte: Del Rey, 2008. p. 32.

${ }^{108}$ PEÑARANDA RAMOS, Enrique; SUÁREZ GONZÁLEZ, Carlos; CANCIO MELIÁ, Manuel. Um novo sistema do direito penal: considerações sobre a teoria de Günther Jakobs, cit., p. 8.

${ }^{109}$ JAKOBS, Günther. Tratado de direito penal: teoria do injusto penal e culpabilidade, cit., p. 32.

${ }^{110}$ JAKOBS, Günther. ¿Qué protege el derecho penal: bienes jurídicos o la vigencia de la norma? MendozaArgentina: Ediciones Jurídicas Cuyo, 2004. p. 17.
} 
penal "é a eficácia fática das normas que garantem que se pode esperar o respeito aos bens jurídicos, às funções e à paz jurídica"111.

Jakobs leva em consideração, pelo menos em alguma medida ${ }^{112}$, as ideias formuladas pelo sociólogo alemão Niklas Luhmann na elaboração da sua "teoria de sistemas", segundo a qual a análise da sociedade moderna, por sua complexidade, reclamaria o abandono da "teoria da ação" em prol de um sistema baseado na comunicação $^{113}$.

Pela perspectiva de Jakobs, a teoria da imputação objetiva assume ares de universalidade, podendo incidir tanto sobre crimes dolosos, como delitos culposos, destacando-se, porém, que em ambas as hipóteses a "opinião" ou a "interpretação" que o autor faz da sua própria conduta apresenta-se como elemento ocioso na elaboração do juízo de atribuição de responsabilidade. Vigora, dessa forma, uma "interpretação objetiva, orientada com base no papel do autor" ${ }^{\text {"14 }}$, desprezando-se, por conseguinte, qualquer noção sobre o conhecimento, pelo sujeito, da conduta.

Como adverte Jakobs, tanto "no caso de concorrer dolo como no de concorrer culpa é o significado geral e, portanto, objetivo, o que interessa sob o ponto de vista social, precisamente porque o decisivo é que se tratam de fatos que produzem uma perturbação social e não de meras peculiaridades individuais" ${ }^{115}$.

A teoria da imputação objetiva de Jakobs, que na avaliação de Luís Greco impressiona por apresentar uma sólida base filosófica-sociológica ${ }^{116}$, e pela "precisão e

\footnotetext{
${ }^{111}$ JAKOBS, Günther. Tratado de direito penal: teoria do injusto penal e culpabilidade, cit., p. 78-79.

${ }^{112}$ PEÑARANDA RAMOS, Enrique; SUÁREZ GONZÁLEZ, Carlos; CANCIO MELIÁ, Manuel. Um novo sistema do direito penal: considerações sobre a teoria de Günther Jakobs, cit., p. 7.

${ }^{113}$ Luhmann propõe, em síntese, conceber o indivíduo e sociedade fazendo-o através de sistemas psíquicos e sistemas sociais enquanto ambiente um do outro. No ponto, anota Orlando Villas Bôas Filho que a teoria dos sistemas descreve o direito positivo moderno "como um subsistema (ou sistema parcial) funcional, auto-referencial e autopoiético, que compõe, ao lado de outros subsistemas funcionais (política, economia, ciência, sistema educacional, religião etc.), uma sociedade, entendida como sistema global que se reproduz a autopoieticamente mediante um processo comunicativo que (...) consiste na síntese de três operações seletivas: mensagem, informação e compreensão" (VILLAS BÔAS FILHO, Orlando. Teoria dos sistemas e o direito brasileiro. São Paulo: Saraiva, 2009. p. 139).

${ }^{114}$ JAKOBS, Günther. A imputação objetiva no direito penal, cit., p. 22. Registre-se, contudo, que conquanto abrangente dos crimes dolosos, o próprio Jakobs reconhece que é na figura dos crimes culposos que a teoria da imputação objetiva ostenta relevância prática (Id. Ibid., p. 23).

${ }^{115}$ Id. Ibid., p. 23.

${ }^{116}$ ROXIN, Claus. Funcionalismo e imputação objetiva no direito penal, cit., p. 130.
} 
harmonia com que cada problema é resolvido"117, conquanto não seja imune a críticas, deve ser examinada, concretamente, em dois níveis: o da (i) imputação objetiva do comportamento; e o da (ii) imputação objetiva do resultado, no que tange aos crimes materiais ou de resultado. No primeiro patamar, a imputação objetiva do comportamento reclama a verificação prévia de quatro instituições dogmáticas ${ }^{118}$, quais sejam: (a) o risco permitido; (b) o princípio da confiança; (c) a proibição de regresso e (d) a capacidade da vítima $^{119}$.

Haverá risco permitido em qualquer relacionamento social, uma vez que a sociedade não se destina à máxima proteção aos bens jurídicos, mas dar azo às interações. Partir do pressuposto de que não existe risco permitido na sociedade moderna significa dizer, na dicção de Jakobs, que não existe comportamento social. Nesse caso, a verificação da imputação penal deverá levar em consideração as normas que determinam as condutas que conformam o risco permitido ${ }^{120}$. Trata-se, sem dúvida, de risco definido normativamente ${ }^{121}$.

Em relação ao princípio da confiança, destaca Jakobs que "não faz parte do papel do cidadão controlar de maneira permanente a todos os demais"122. No âmbito da teoria da imputação objetiva, Jakobs assinala que o princípio da confiança pode apresentarse sob duas formas: a primeira, atrelada ao caso em que o indivíduo, agindo como um terceiro, enseja uma situação que se revela inócua, inofensiva, desde que o autor, que atua em seguida, observe seus deveres. Jakobs exemplifica: "alguém entrega a outra pessoa um relógio alheio de grande valor, e isto somente não causará um dano se quem recebe o relógio pega-o com cuidado. Normalmente, pode-se confiar em que assim se suceda" ${ }^{, 123}$.

A segunda modalidade por intermédio da qual o princípio da confiança emerge diz respeito àquelas hipóteses em que um terceiro elabora seu proceder em

\footnotetext{
${ }^{117}$ ROXIN, Claus. Funcionalismo e imputação objetiva no direito penal, cit., p. 130.

${ }^{118}$ PEÑARANDA RAMOS, Enrique; SUÁREZ GONZÁLEZ, Carlos; CANCIO MELIÁ, Manuel. Um novo sistema do direito penal: considerações sobre a teoria de Günther Jakobs, cit., p. 85.

${ }^{119}$ JAKOBS, Günther. La imputación objetiva en derecho penal, cit., p. 28 e ss.

${ }^{120}$ Id. Ibid., p. 29.

${ }^{121}$ PEÑARANDA RAMOS, Enrique; SUÁREZ GONZÁLEZ, Carlos; CANCIO MELIÁ, Manuel. Um novo sistema do direito penal: considerações sobre a teoria de Günther Jakobs, cit., p. 88.

${ }^{122}$ JAKOBS, Günther. A imputação objetiva no direito penal, cit., p. 28.

${ }^{123}$ Id. Ibid., p. 28.
} 
conformidade com aquilo que dele se espera, de modo que o autor, se cumprir seus deveres, não produzirá qualquer dano. Agora pelas palavras de Jakobs: "o cirurgião confia em que o material que utiliza na operação tenha sido convenientemente esterilizado"124.

A proibição de regresso diz respeito a um "comportamento, que de modo invariavelmente considerado inofensivo, não constitui participação em uma atividade não permitida" ${ }^{\prime 25}$. Esse instituto da imputação objetiva tem implicação, a nosso ver, nos casos hodiernamente tratados pela doutrina como sendo de ação neutra ou cotidiana, na medida em que o agente (autor) deturpa ou desvia até o limite delitivo o comportamento do terceiro, que, isoladamente tomado, carece de caráter criminoso. No exemplo desenhado por Jakobs, se o taxista " $\underline{X}$ " leva em seu veículo o assaltante " $\underline{Y}$ ” até o banco " $\underline{W}$ " para que este o roube, a " $\underline{X}$ " não pode ser imputado o delito plasmado no artigo 157 do Código Penal brasileiro, pois "o terceiro assume perante o autor um comportamento comum limitado e circunscrito por seu próprio papel; comportamento comum e do qual não se pode considerar seja parte de um delito" ${ }^{126}$. Nesse caso, acrescenta Jakobs, afiguram-se irrelevantes até mesmo os conhecimentos que o taxista " $\underline{X}$ " eventualmente possa ter acerca das deletérias intenções do assaltante de bancos. Diga-se de outro modo: " $\underline{X}$ " pode até mesmo ter conhecimento prévio do desiderato criminoso de " $\underline{Y}$ ", isto é, de sua "planificação delitiva", mas se o seu comportamento ficou circunscrito ao papel social, descabe cogitar de quebra de expectativa normativa, inexistindo espaço para a atribuição de responsabilidade penal $^{127}$.

Quando Günther Jakobs menciona a capacidade ou competência da vítima como a quarta e última categoria jurídica para a imputação objetiva do comportamento, ele se refere àqueles casos em que a conduta pode ser debitada da conta da vítima, ou seja, hipóteses nas quais foi a sua própria conduta que ensejou a consequência lesiva.

\footnotetext{
${ }^{124}$ JAKOBS, Günther. A imputação objetiva no direito penal, cit., p. 28.

${ }^{125}$ Id. Ibid., p. 29.

${ }^{126}$ Id. Ibid., p. 30.

${ }^{127}$ Id. Ibid., p. 30. Enrique Peñaranda Ramos, Carlos Suárez González e Manuel Cancio Meliá observam que a formulação da proibição de regresso de Jakobs acaba acarretando uma forma de concepção extensiva de autoria ou uma concepção unitária do injusto, "descrevendo os partícipes e autores como criadores de uma mesma unidade de sentido e, portanto, como intervenientes num injusto coletivo" (PEÑARANDA RAMOS, Enrique; SUÁREZ GONZÁLEZ, Carlos; CANCIO MELIÁ, Manuel. Um novo sistema do direito penal: considerações sobre a teoria de Günther Jakobs, cit., p. 92).
} 
O caso mais conhecido da denominada capacidade da vítima reside, segundo Jakobs, no consentimento ${ }^{128}$. Além dele, poder-se-ia cogitar de outros casos, como, por exemplo, o infortúnio da vítima e situações em que, com seu próprio comportamento, deu azo a que o resultado criminoso a ela seja imputado, sem que se possa falar em fatalidade ${ }^{129}$.

Neste derradeiro caso existe, de fato, a "lesão de um dever de autoproteção ou inclusive a própria vontade" ${ }^{, 130}$, assim ilustrado por Günther Jakobs: "quem, sem necessidade alguma, pede a uma pessoa claramente ébria que realize um ato de certa complexidade, como por exemplo conduzir um automóvel por um determinado trajeto, deve atribuir-se, ao menos em parte, as consequências negativas resultantes. Quem participa de uma disputa violenta, como por exemplo um combate de boxe, não tem direito a não resultar lesionado"131.

De outro lado, no que tange à imputação objetiva do resultado, segundo degrau no juízo da imputação objetiva esquadrinhada por Jakobs, levar-se-á em conta o risco não permitido criado pelo agente e a sua aptidão para explicar o acontecimento. Nessa perspectiva, o liame entre o comportamento não permitido e o resultado somente pode ser aferido se houver uma prévia resolução do que venha a se constituir como sendo a "orientação da sociedade"" 132 . Aqui emerge em Jakobs o conceito de planificação ou

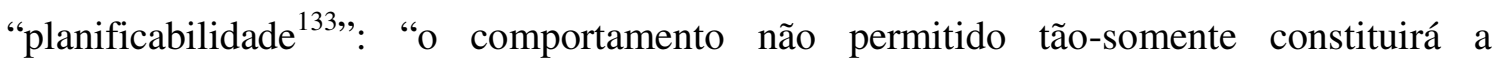
explicação do acontecimento lesivo quando o curso causal que dele deriva se tenha produzido de tal maneira que se pudesse planejar sua inocorrência"134.

Também é sob esse contexto que Jakobs procurar explicar as várias questões relacionadas aos chamados danos particulares (ou derivados), em que o resultado produzido pelo comportamento do agente coloca a vítima em uma situação na qual se revela um dano ulterior que pode ser atribuído a uma conduta posterior da própria vítima

\footnotetext{
${ }^{128}$ JAKOBS, Günther. A imputação objetiva no direito penal, cit., p. 31.

${ }^{129}$ Id. Ibid., p. 32.

${ }^{130}$ Id. Ibid., p. 32.

${ }^{131}$ Id. Ibid., p. 32.

${ }^{132}$ Id. Ibid., p. 81.

${ }^{133}$ Id. Ibid., p. 81.

${ }^{134}$ PEÑARANDA RAMOS, Enrique; SUÁREZ GONZÁLEZ, Carlos; CANCIO MELIÁ, Manuel. Um novo sistema do direito penal: considerações sobre a teoria de Günther Jakobs, cit., p. 94.
} 
ou alheio, como sucede com o caso da vítima que morre no hospital a que foi levada após uma tentativa de homicídio em razão de uma complicação na operação cirúrgica a que foi submetida, bem como nos casos de comportamento sem procedimentos de segurança, onde o comportamento do autor é considerado não permitido por ter ele deixado de colocar em funcionamento, em marcha, procedimentos de segurança ${ }^{135}$.

\subsection{Imputação objetiva e criminalidade moderna?}

Tem-se sustentado em algumas oportunidades ${ }^{136}$ que o manejo da teoria da imputação objetiva resolveria primordialmente os problemas de atribuição de responsabilidade penal inerentes à nova ou moderna criminalidade. Porém, como observa Luís Greco, não indicam exemplos concretos por intermédio dos quais a aplicação da teoria da imputação objetiva revelar-se-ia propícia, quiçá imprescindível, para a resolução dos problemas penais que surgem no bojo de uma nova modalidade de Direito Penal ${ }^{137}$.

Sob esse panorama, Luís Greco recorda que a maior parte dos exemplos doutrinários sobre a aplicação da teoria da imputação objetiva encontra-se relacionada a uma "criminalidade que se pode adjetivar de quase tudo, menos de moderna"138.

Para Luís Greco, antes de se traduzir em veículo teórico hábil a proporcionar imputação penal à criminalidade de colarinho branco ${ }^{139}$, a teoria

\footnotetext{
${ }^{135}$ JAKOBS, Günther. A imputação objetiva no direito penal, cit., p. 88.

${ }^{136}$ Nessa esteira, por exemplo, de ver-se Antonio Luís Chaves de Camargo (Imputação objetiva e direito penal brasileiro, cit., p. 186), quando sugere, ainda que superficialmente, a adoção da teoria da imputação objetiva à "criminalidade organizada e internacional".

${ }^{137}$ ROXIN, Claus. Funcionalismo e imputação objetiva no direito penal, cit., p. 178.

${ }^{138}$ Id. Ibid., p. 180.

${ }^{139} \mathrm{O}$ conceito de crime de colarinho branco ou white collar-crime foi criado pelo sociólogo norte-americano Edwin Sutherland no ano de 1939, por ocasião de sua intervenção perante a American Sociological Association. Para Sutherland o conceito de crime de colarinho branco engloba cinco elementos, a saber: (a) trata-se de um crime; (b) é cometido por uma pessoa que goza de respeito, ou seja, seus autores são pessoas respeitáveis; (c) o autor do crime é de um estatuto social alto; (d) o crime é perpetrado no exercício da profissão, o que, para Sutherland, excluirá todos os crimes que, apesar de cometidos por agentes com as características supramencionadas, se relacionam com a sua vida privada; (e) o crime acarreta, em regra, uma violação de confiança. Note-se, nesse passo, que a definição de Sutherland reforça o aspecto subjetivo do crime, centrando a sua atenção nas características do sujeito do delito, deixando de fora do conceito uma nota imprescindível para a sua compreensão teleológica, qual seja, o caráter de impunidade das condutas
} 
da imputação objetiva tem encontrado ambiente mais fértil nos delitos tradicionais ${ }^{140}$.

A análise da jurisprudência brasileira, por sinal, confirma a conclusão de Luís Greco: afora a inegável constatação de que são escassos os casos judiciais tratados com base na teoria da imputação objetiva, os poucos precedentes jurisprudenciais que se valeram desse recurso teórico referem-se majoritariamente a delitos de natureza culposa ${ }^{141}$.

Não obstante, partindo do pressuposto que a teoria da imputação objetiva aplica-se a toda e qualquer espécie de crime (doloso, culposo, formal, material e de mera conduta, comissivo ou omissivo), soa demasiada restritiva a afirmação de que a criminalidade moderna - na qual se insere evidentemente a criminalidade empresarial passaria ao largo das soluções propostas pela teoria da imputação objetiva.

Particularmente no âmbito do Direito Econômico, a teoria da imputação objetiva consubstancia um importante instrumento de atribuição de responsabilidade ao estabelecer critérios distintivos entre uma conduta neutra ${ }^{142}$ e uma conduta criminosa ${ }^{143}$.

abrangida. Nesse sentido: SANTOS, Cláudia Maria Cruz. O crime de colarinho branco: da origem do conceito e sua relevância criminológica à questão da desigualdade na administração da justiça penal. Coimbra: Boletim da Faculdade de Direito da Universidade de Coimbra; Coimbra Ed., 2001. p. 46. (Studia Iuridica, n. 56).

${ }^{140}$ GRECO, Luís. Introdução. In: ROXIN, Claus. Funcionalismo e imputação objetiva no direito penal, cit., p. 180.

${ }^{141}$ No Superior Tribunal de Justiça, por exemplo, dos quatro precedentes encontrados com a referência de pesquisa "teoria da imputação objetiva", três dizem respeito ao crime de homicídio culposo, a saber: HC 46525, j. em 21.03.2006, Rel. Ministro Arnaldo Esteves Lima; Resp n. ${ }^{\circ}$ 822517, j. em 12.06.2007, Rel. Ministro Gilson Dipp e HC 68871, j. em 6.08.2009, Rel. Ministra Maria Thereza de Assis Moura.

${ }^{142}$ Condutas ou ações neutras, segundo Luís Greco, "seriam todas as contribuições a fato ilícito alheio não manifestamente puníveis" (GRECO, Luís. Cumplicidade através de ações neutras: a imputação objetiva na participação. Rio de Janeiro: Renovar, 2004. p. 110). Para Luís Greco, a utilização da teoria da imputação objetiva na participação criminosa simplifica a interpretação dos casos visto que se trabalha com apenas uma teoria, diminui a possibilidade de soluções contraditórias e enseja maior alcance do que as demais teorias da cumplicidade (Id. Ibid., p. 15). Na mesma esteira, vide a tese de Doutorado apresentada em 2012 na Faculdade de Direito da Universidade de São Paulo por João Daniel Rassi intitulada A imputação das ações neutras e o dever de solidariedade no direito penal brasileiro. 2012. Tese (doutorado) - Faculdade de Direito, Universidade de São Paulo, São Paulo, 2012. p. 22 e ss.

${ }^{143}$ Tome-se como exemplo, nesse sentido, o caso analisado por Schünemann, no qual um funcionário de uma instituição financeira transfere, a pedido de seu cliente, recursos para o exterior, visando, com isso, sonegar impostos. Neste caso, a contribuição do funcionário do Banco não pode ser considerada penalmente neutra porque ela representou uma ajuda realmente imprescindível para a supressão de tributos, pois somente com a ajuda desta modalidade de transferência que se encontrava à disposição os recursos puderam ser enviados eficazmente para fora do país (SCHÜNEMANN, Bernd. Consideraciones sobre la teoría de la imputación objetiva. In: _. Obras. 1. ed. Santa Fe: Rubinzal-Culzoni, 2009. p. 400-401. (Colección Autores de Derecho Penal, t. 1)). Sobre o mesmo exemplo, em que o cliente é denominado "A" e bancário "B", Luís Greco afirma: "B pode ser punível a título de participação. Ele foi causa do delito principal, porque, se não 
Tomemos como exemplo um caso de "lavagem" de dinheiro. Gustavo Henrique Badaró e Pierpaolo Cruz Bottini indicam a adequação da teoria da imputação objetiva para o crime de branqueamento de capitais para distinguir a participação criminosa daquela que é meramente neutra e, assim, irrelevante do ponto de vista penal.

Badaró e Bottini exemplificam a situação nestes termos: "o gerente do banco que movimenta recursos entre as contas correntes, cria um risco de lavagem de dinheiro, porque os valores podem ter origem ilícita e tal operação dificultará seu rastreamento. No entanto, se ele observa as regras profissionais pertinentes e as normas de cuidado exigíveis, não ultrapassa o risco permitido. Mesmo que colabore efetivamente com a lavagem de dinheiro, este resultado não lhe será objetivamente imputável, nem a título de participação" ${ }^{, 144}$.

Badaró e Bottini, entretanto, ponderam que haverá risco não permitido quando houver a violação de uma norma de cuidado, as quais podem ter como base (i) caráter institucional (formalmente estabelecidas em regulamentos e outros atos normativos), (ii) caráter técnico (preceitos regulamentadores de uma determina atividade profissional) ou (iii) caráter geral (regras de experiência comum) ${ }^{145}$. Nesse sentido, poderse-á cogitar de participação penalmente relevante na hipótese dele possuir um conhecimento especial acerca da empreitada criminosa, ou seja, quando o agente possuir "plena ciência de que os valores são provenientes de infração penal e que sua conduta contribuirá para a reciclagem. Nesses casos, sempre será exigível a abstenção da conduta, porque previsível o processo de lavagem e exigível a cautela, uma vez que a cautela é idônea para proteger a administração da Justiça e sem alto custo social, colabore com a

\footnotetext{
tivesse contribuído, o resultado teria ocorrido de outra forma. Além disso, criou um risco, vez que tinha conhecimento dos planos de A. o problema é se esse risco há de ser considerado permitido ou proibido. As manobras de ocultação da transferência pressupõem uma certa confiança entre A e B, de modo que elas não poderiam ter sido obtidas com a mesma facilidade de outro bancário. Assim, a proibição dificultaria consideravelmente a transferência de capitais, sendo um meio idôneo para melhorar a situação do bem jurídico. B cria, portanto, um risco juridicamente desaprovado. Como ele sabe o que está fazendo, há dolo, e inexistindo quaisquer excludentes de antijuridicidade ou culpabilidade, cometeu um crime, sendo, assim, punível a título de cumplicidade na sonegação fiscal" (GRECO, Luís. Cumplicidade através de ações neutras: a imputação objetiva na participação, cit., p. 162-163).

${ }^{144}$ BADARÓ, Gustavo Henrique; BOTTINI, Pierpaolo Cruz. Lavagem de dinheiro: aspectos penais e processuais penais: comentários à Lei 9.613/1998, com as alterações da Lei 12.683/2012. São Paulo: Ed. Revista dos Tribunais, 2012. p. 123-124.

${ }^{145}$ Id. Ibid., p. 130.
} 
ocultação, dissimulação ou qualquer outro ato de encobrimento de valores que sabe provenientes de atos ilícitos"146.

Com efeito, parece-nos que, uma vez superada a imprecisão terminológica que permeia o tema (criminalidade empresarial), será possível estabelecer, em relação aos crimes levados a efeito sob contexto coletivo ou organizacional, uma teoria da imputação calcada na criação de um risco juridicamente proibido e na verificação desse risco no resultado com vistas a responsabilizar adequadamente os agentes que são, de fato, responsáveis e, de igual modo, excluir o âmbito de imputação os indivíduos que, embora tenham composto a organização empresarial, não devem ser responsabilizados penalmente. Esse tema consubstancia o objeto da investigação do Capítulo IV do presente trabalho.

${ }^{146}$ BADARÓ, Gustavo Henrique; BOTTINI, Pierpaolo Cruz. Lavagem de dinheiro: aspectos penais e processuais penais: comentários à Lei 9.613/1998, com as alterações da Lei 12.683/2012, cit., p. 128. 


\section{ATIVIDADE EMPRESARIAL E DIREITO PENAL}

\subsection{A conformação da organização empresarial para a imputação}

A organização empresarial moderna representa uma realidade social que não pode ser tratada como sendo meramente o resultado da soma de seus componentes. Hodiernamente, existem complexas organizações empresariais marcadas pela fragmentação de suas atividades, bem como pela hierarquia e a pela divisão do trabalho.

Como destaca o sociólogo Reinaldo Dias, a divisão do trabalho "influencia significativamente a conduta e o comportamento dos indivíduos nas organizações. $\mathrm{O}$ cumprimento das responsabilidades da posição que os indivíduos ocupam os leva a adotar de maneira consciente ou inconsciente condutas próprias da posição que são expressas nos objetivos do cargo ou função e formalizadas nos manuais de funções onde se encontra a padronização das atividades concretizando a mecanização do trabalho" ${ }^{147}$.

Dessa realidade deriva a constatação de que, a partir de certo grau de sofisticação, não é mais possível encontrar uma pessoa determinada sobre a qual recaiam, ao mesmo tempo, a criação do risco ou sua intervenção com o conhecimento do risco da atividade ou do produto ou mesmo uma pessoa que detenha a informação global sobre a atividade empresarial. Por esse motivo, a análise da imputação penal em ambientes organizacionais passa pelo prévio conhecimento da conformação societária da organização.

Tendo presente, pois, que a estrutura organizativa contribui para a adequada utilização dos modelos de atribuição de responsabilidade penal das pessoas físicas que compõem o ente empresarial, passaremos à investigação dos principais aspectos estruturais que delineiam o perfil das sociedades empresárias, com destaque para as Sociedades Anônimas, por consubstanciarem típico caso em que o poder de controle encontra-se pulverizado ou desmembrado por intermédio de diversos órgãos de administração.

${ }^{147}$ DIAS, Reinaldo. Sociologia das organizações. São Paulo: Atlas, 2008. p. 169. 


\subsection{A administração empresarial}

\subsubsection{Conceito}

Dentro de um ente coletivo, a distribuição de atribuições, responsabilidades e obrigações, de forma organizada, entre vários indivíduos ou núcleos, é uma das premissas para o bom funcionamento de uma companhia. Nesse contexto, a administração da companhia é o ente responsável pela supervisão dos negócios, busca pelo objeto social e gestão diária das atividades.

A Lei nº 6.404/1976 (Lei das Sociedades Anônimas) atribui à administração um caráter orgânico. Assim, o órgão é considerado elemento integrante da companhia (pessoa jurídica) e todas as vontades expressadas por ele (órgão) decorrentes de seu poder funcional, atribuídos por lei ou estatuto, são imputáveis diretamente à companhia.

Do ponto de vista da estruturação da administração de uma companhia, o Direito Comparado adota, em síntese, dois modelos: (i) o sistema unitário ou monista, em que apenas um órgão de administração concentra as atribuições administrativas da companhia e (ii) o sistema bipartido ou dualista, em que existem dois órgãos, um com finalidade de fiscalizar as atividades dos administradores e outro que atua na gestão dos negócios diários da companhia ${ }^{148}$. No Brasil, existe um sistema considerado híbrido pela doutrina, porque a existência do Conselho de Administração só é obrigatória legalmente em companhias abertas, sociedades de economia mista e nas sociedades de capital autorizado $^{149}$. Dessa forma, nas sociedades em que a Lei n. ${ }^{o}$ 6.404/1976 não exige a presença do Conselho de Administração, a Diretoria funciona simultaneamente como órgão executivo e deliberativo e, portanto, mais próximo do modelo unitário. Nas companhias em que existe obrigatoriamente o Conselho de Administração, o sistema aproxima-se do

\footnotetext{
${ }^{148}$ Estados Unidos, Inglaterra, Portugal e Espanha adotam o sistema monista. Alemanha e Suíça utilizam o modelo dualista.

${ }^{149}$ Art. 138 da Lei n. ${ }^{\circ}$ 6.404/1976: A administração da companhia competirá, conforme dispuser o estatuto, ao conselho de administração e à diretoria, ou somente à diretoria. $§ 1^{\circ} \mathrm{O}$ conselho de administração é órgão de deliberação colegiada, sendo a representação da companhia privativa dos diretores. $\S 2^{\circ}$ As companhias abertas e as de capital autorizado terão, obrigatoriamente, conselho de administração.
} 
modelo dualista, muito embora a Lei das Sociedades Anônimas ainda autorize que um terço dos membros do Conselho de Administração sejam eleitos Diretores ${ }^{150}$.

\subsection{2 Órgãos de administração}

\subsubsection{Introdução: o administrador da sociedade empresária}

O administrador é o responsável por manifestar a vontade da companhia e por ela se obriga. Cabe à administração da companhia praticar os atos de gestão das atividades diárias da companhia e direcionar os negócios da sociedade empresária com o escopo de atingir o objeto social. A atuação dos administradores é ampla e não existe limitação legal ou rol taxativo das funções atribuídas aos administradores de uma companhia. A restrição inexiste porque é impossível prever todas as situações que exigiriam a atuação dos administradores, sobretudo diante da crescente complexidade das organizações empresariais e das relações jurídicas estabelecidas entre elas e terceiros.

Os administradores pautam seus atos para atingir a finalidade social da companhia e, em regra, a lei permite que eles atuem de forma discricionária na escolha dos instrumentos adequados para que esse fim seja alcançado. Importante esclarecer que o administrador, com a evolução da sociedade, deixou de ser o proprietário da companhia (acionista) e, com mais frequência, adota-se um órgão formado por profissionais independentes ${ }^{151}$, dissociados dos controladores e da própria companhia.

\footnotetext{
${ }^{150}$ Art. 143. A Diretoria será composta por 2 (dois) ou mais diretores, eleitos e destituíveis a qualquer tempo pelo conselho de administração, ou, se inexistente, pela assembleia-geral, devendo o estatuto estabelecer: (...) $1^{\circ}$ Os membros do conselho de administração, até o máximo de $1 / 3$ (um terço), poderão ser eleitos para cargos de diretores.(...)".

${ }^{151}$ De acordo com o Regulamento do Novo Mercado, "Conselheiro Independente caracteriza-se por: (i) não ter qualquer vínculo com a Companhia, exceto participação de capital; (ii) não ser Acionista Controlador, cônjuge ou parente até segundo grau daquele, ou não ser ou não ter sido, nos últimos 3 anos, vinculado a sociedade ou entidade relacionada ao Acionista Controlador (pessoas vinculadas a instituições públicas de ensino e/ou pesquisa estão excluídas desta restrição); (iii) não ter sido, nos últimos 3 anos, empregado ou diretor da Companhia, do Acionista Controlador ou de sociedade controlada pela Companhia; (iv) não ser fornecedor ou comprador, direto ou indireto, de serviços e/ou produtos da Companhia, em magnitude que
} 
Essa evolução decorre de imposições regulatórias, como sucede com as companhias abertas listadas na BM\&FBovespa e também de alterações de comportamento motivadas em obediência aos princípios de governança corporativa, impostas por recentes alterações legislativas, como, por exemplo, a denominada Lei Anticorrupção ${ }^{152}$.

\subsubsection{2. Órgãos de administração nas sociedades anônimas}

\subsection{O Conselho de Administração}

O Conselho de Administração das Sociedades Anônimas é o órgão de deliberação colegiada e a ele compete estabelecer as diretrizes dos negócios da companhia e supervisão das atividades de gestão dos seus diretores. O rol das atribuições do Conselho de Administração está previsto no artigo 142 da Lei n. ${ }^{\circ}$ 6.404/1976 ${ }^{153}$ e não é considerado taxativo, servindo apenas para delinear as atribuições mínimas, que poderão ainda ser acrescidas de outras competências previstas no Estatuto, desde que não sejam atribuições privativas de outro órgão.

\footnotetext{
implique perda de independência; (v) não ser funcionário ou administrador de sociedade ou entidade que esteja oferecendo ou demandando serviços e/ou produtos à Companhia; (vi) não ser cônjuge ou parente até segundo grau de algum administrador da Companhia; (vii) não receber outra remuneração da Companhia além da de conselheiro (proventos em dinheiro oriundos de participação no capital estão excluídos desta restrição)."

${ }^{152}$ Lei n. ${ }^{\circ} 12.846$, de $1^{\circ}$ agosto de 2013.

${ }^{153}$ Art. 142. Compete ao conselho de administração: I - fixar a orientação geral dos negócios da companhia; II - eleger e destituir os diretores da companhia e fixar-lhes as atribuições, observado o que a respeito dispuser o estatuto; III - fiscalizar a gestão dos diretores, examinar, a qualquer tempo, os livros e papéis da companhia, solicitar informações sobre contratos celebrados ou em via de celebração, e quaisquer outros atos; IV - convocar a assembléia-geral quando julgar conveniente, ou no caso do artigo 132; V - manifestarse sobre o relatório da administração e as contas da diretoria; VI - manifestar-se previamente sobre atos ou contratos, quando o estatuto assim o exigir; VII - deliberar, quando autorizado pelo estatuto, sobre a emissão de ações ou de bônus de subscrição; VIII - autorizar, se o estatuto não dispuser em contrário, a alienação de bens do ativo não circulante, a constituição de ônus reais e a prestação de garantias a obrigações de terceiros; IX - escolher e destituir os auditores independentes, se houver. Existem, contudo, outras atribuições previstas ao longo da Lei das Companhias atribuem competência ao Conselho, como se percebe do artigo 59, § 1 e do artigo 279.
} 
Entre as principais competências atribuídas ao Conselho de Administração está a fixação da orientação dos negócios da companhia ${ }^{154}$, definição de estratégia de atuação, aprovação de contas da empresa, eleição, fiscalização e destituição dos diretores, avaliação de processos de aquisição ou reestruturação societária.

A fiscalização exercida pelo Conselho sobre os Diretores não diz respeito apenas à legalidade dos atos ${ }^{155}$; o Conselho de Administração deverá avaliar a conveniência dos atos e as vantagens e riscos assumidos pela Companhia, uma vez que é de sua competência a orientação geral dos negócios com o desiderato de atingir o objeto social.

Como órgão de deliberação colegiada, os membros do Conselho de Administração não manifestam sua vontade individual e todas as decisões são tomadas por meio de reuniões, as quais, para que produzam efeitos regulares, devem ser convocadas de forma regular e em consonância com as disposições legais e o Estatuto social.

No âmbito do Conselho de Administração prevalecerá a vontade da maioria de seus membros, que vinculará a todos - sejam eles ausentes ou dissidentes. Os dissidentes poderão apresentar discordância em votos separados. No que tange à composição, o Conselho de Administração deverá ser composto de, no mínimo, três membros, que necessariamente são pessoas naturais eleitas pela assembleia-geral, a quem, também, cabe destitui-los ${ }^{156}$.

O Conselho de Administração atua como intermediador dos interesses dos acionistas (assembleia geral) e a gestão dos negócios da companhia (Diretoria) e, embora não possua o mesmo poder atribuído por outros países ${ }^{157}$ na estrutura da sociedade, tem

\footnotetext{
${ }^{154}$ Dentro do conceito de fixar a orientação dos negócios competirá ao conselho de administração analisar o mercado, o desempenho das atividades, as operações celebradas, os riscos envolvidos, políticas de compliance, avaliação do negócio e possibilidades de expansão. Em síntese, todo o planejamento com o objetivo de atingir o fim social.

${ }^{155}$ Ao contrário do que ocorre em relação ao Conselho Fiscal, cujo dever de fiscalizar limita-se à apuração de legalidade ou não do ato.

${ }^{156}$ Com a alteração do artigo 146 da Lei n. ${ }^{\circ} 6.404 / 1976$ pela Lei n ${ }^{\circ} 12.431 / 2001$, não é mais necessário que os membros do Conselho de Administração sejam acionistas da companhia. Na prática, esse pré-requisito era atendido com a entrega de uma ação ao conselheiro eleito, que deveria devolvê-la quando fosse destituído ou encerrasse seu mandato.

${ }^{157}$ Como evidencia Nélson Eizirik: "Ainda que nosso sistema, no que diz respeito ao conselho de administração, aproxime-se do norte americano, naquele país o órgão (board of directors) dispõe de mais poderes, sendo absolutamente hegemônico na estrutura de poder das companhias; com efeito, lá vigora plenamente a chamada director primacy doctrine, que importa na concentração de poderes nas mãos dos
} 
sido utilizado como importante elemento para adoção de boas práticas de governança corporativa.

A natureza do órgão e de suas atribuições recomenda que os votos proferidos no âmbito do Conselho de Administração da companhia sejam abertos, o que deriva do princípio da transparência, além de representar importante instrumento de garantia para posterior apuração da responsabilidade pessoal e individual de cada conselheiro pelas deliberações irregulares ou faltosas tomadas nas reuniões do órgão.

Nesse passo, cabe registrar que o aumento da complexidade das organizações empresariais decorrentes da globalização e a maior regulamentação e fiscalização estatal em relação atos de gestão irregulares provocou uma alteração do perfil dos membros do Conselho de Administração, com a inclinação das organizações empresariais à eleição de Conselheiros com experiências diversas e variadas, bem como pela contratação de Conselheiros externos, limitando a presença, em consequência, de membros do Conselho vinculados a acionistas ${ }^{158}$.

O Conselho de Administração, assim, divide-se entre os conselheiros internos, vinculados à companhia, como acionistas e empregados com o contrato de trabalho suspenso para o exercício do cargo e os conselheiros externos, que podem não possuir qualquer vínculo com a companhia, denominados conselheiros independentes, e conselheiros externos, que não possuem um vínculo atual, mas de alguma forma têm relação com a companhia, como é o caso de antigos Diretores ou consultores da companhia. Na prática, verifica-se a saudável profissionalização do Conselho de Administração, proporcionando maior independência, competência e eficiência no desempenho da função do órgão.

O Conselho de Administração necessariamente deverá contar com um presidente, essencial para o bom funcionamento do órgão. A escolha desse presidente

\footnotetext{
membros do conselho de administração, que tem competência para dirigir os negócios sociais, podendo delegar aos diretores (officers) algumas das tarefas de gestão" (EIZIRIK, Nelson. A Lei das S/A comentada: arts. 121 a 188. São Paulo: Quartier Latin, 2011. v. 2, p. 265).

${ }^{158}$ O Regulamento do Novo Mercado propõe que $20 \%$ dos membros do conselho de administradores sejam conselheiros independentes e, portanto, sem qualquer vínculo com a companhia.
} 
poderá ser realizada em assembleia geral ou pelo próprio Conselho ${ }^{159}$ e o estatuto social da companhia é que irá estabelecer qual órgão será o competente para esse fim. A função do presidente é coordenar e conduzir as atividades do órgão, inclusive nas etapas de convocação de reuniões, pauta de deliberações e divulgação das deliberações tomadas no âmbito do conselho. O presidente terá, ainda, o dever de atuar como mediador dos conflitos eventualmente existentes entre os demais membros do Conselho de Administração.

Além disso, embora seja ideal que as decisões tomadas pelo Conselho de Administração se deem por consenso, não se pode afastar a possibilidade de deliberações com empate, em que o voto de qualidade ou voto de desempate normalmente é previsto no estatuto social e atribuído ao presidente do órgão. O estatuto também poderá atribuir ao presidente algumas atribuições exclusivas, como a coordenação de comitês ou órgãos consultivos supervisão de determinadas atividades estratégicas da companhia ou da gestão de determinados diretores.

O estatuto da companhia deverá disciplinar a forma de convocação, instalação e funcionamento do órgão e, muitas vezes, o estatuto disciplina ainda necessidade de quórum qualificado para resoluções de algumas matérias ${ }^{160}$. É recomendado, contudo, que a exigência de quórum específico para algumas matérias seja utilizada de forma moderada e restritiva para evitar o travamento de processos decisórios ou criação de impasses na companhia ${ }^{161}$.

O Conselho de Administração é considerado o principal instrumento de governança corporativa e atua para preservar os interesses tanto dos acionistas como dos

\footnotetext{
${ }^{159}$ Ar. 140 . O conselho de administração será composto por, no mínimo, 3 (três) membros, eleitos pela assembleia-geral e por ela destituíveis a qualquer tempo, devendo o estatuto estabelecer: I - o número de conselheiros, ou o máximo e mínimo permitidos, e o processo de escolha e substituição do presidente do conselho pela assembleia ou pelo próprio conselho;

${ }^{160}$ Artigo 140 da Lei n. ${ }^{\circ}$ 6.404/1976: O conselho de administração será composto por, no mínimo, 3 (três) membros, eleitos pela assembleia-geral e por ela destituíveis a qualquer tempo, devendo o estatuto estabelecer: (...) IV - as normas sobre convocação, instalação e funcionamento do conselho, que deliberará por maioria de votos, podendo o estatuto estabelecer quorum qualificado para certas deliberações, desde que especifique as matérias.

${ }^{161}$ A Lei das Companhias também estipula que o estatuto pode prever a participação de empregados na composição do Conselho de Administração, em uma tendência da legislação brasileira de fazer o Conselho de Administração um órgão utilizado também com escopo do interesse social, integralizando o empregado nos negócios da companhia. Essa eleição será realizada por assembleia e pode contar com a presença dos sindicatos.
} 
chamados stakeholders $^{162}$, bem como para otimizar o retorno dos investimentos aos acionistas.

$\mathrm{Na}$ tentativa de atribuir maior transparência ao órgão e prevenir as responsabilidades pessoais dos Conselheiros, é importante que, além do estatuto, a companhia elabore um regulamento para disciplinar de forma clara as soluções para hipóteses de conflito de interesses, processos decisórios e atribuições de cada conselheiro. Essa divisão de tarefas se mostra ainda mais importante nas organizações empresariais mais complexas e é garantia aos administradores, que responderão exclusivamente pelas atribuições que lhe foram definidas e poderão exercer a gestão de forma mais segura.

Por fim, as reuniões do Conselho de Administração, regularmente convocadas e instauradas, devem ser lavradas em atas e arquivadas na Junta Comercial, devendo ser publicadas todas as deliberações do Conselho que produzirem efeito perante terceiros. As decisões sobre os negócios e planejamento da companhia que poderão afetar acionistas e investidores, como a venda e a compra de valores mobiliários, deverão ser publicadas na condição de Fato Relevante ${ }^{163}$.

\subsection{A Diretoria}

A Diretoria consubstancia órgão essencial em todas as companhias. Cabe à Diretoria a gestão ordinária da companhia e suas atribuições estão previstas em lei e também deverão estar previstas no estatuto. A natureza jurídica da relação estabelecida entre o Diretor e a companhia é de índole societária e não de natureza empregatícia ${ }^{164}$; a eleição dos Diretores deve ser realizada pelo Conselho de Administração ou, na sua

\footnotetext{
${ }^{162}$ Stakeholders são todas as outras pessoas que, sem serem acionistas, são afetadas pelas atividades da companhia.

${ }^{163}$ Artigo 157 da Lei n. ${ }^{\circ}$ 6.404/1976: $§ 4^{\circ}$ Os administradores da companhia aberta são obrigados a comunicar imediatamente à bolsa de valores e a divulgar pela imprensa qualquer deliberação da assembléia-geral ou dos órgãos de administração da companhia, ou fato relevante ocorrido nos seus negócios, que possa influir, de modo ponderável, na decisão dos investidores do mercado de vender ou comprar valores mobiliários emitidos pela companhia.

${ }^{164} \mathrm{Na}$ hipótese de um empregado ser eleito e investido na condição de Diretor, seu contrato de trabalho será suspenso e o individuo passará a ter com a companhia uma relação orgânica de natureza societária.
} 
ausência, pela assembleia geral.

A Lei das Sociedades Anônimas autoriza que até um terço dos membros do Conselho de Administração sejam eleitos como Diretores da companhia, mas as recomendações de boas práticas de governança corporativa não aconselha que isso aconteça, em ordem a evitar a confusão das funções e obstar conflitos de interesses. Com efeito, a eleição de membros do Conselho de Administração para a Diretoria permitira que as pessoas dos fiscalizados pelos atos de gestão se confundam com os membros do órgão fiscalizador.

Os Diretores que não foram eleitos por nenhum dos órgãos mencionados, violando o procedimento legal, não terão efetivos poderes para atuar em nome da companhia e não vincularão a companhia. Nas hipóteses de aplicação da "teoria da aparência”, contudo, o diretor não investido de poderes poderá representar a assunção de obrigações para companhia.

Embora a lei utilize a expressão "representação", a Lei das Sociedades Anônimas adota a teoria organicista e, portanto, os Diretores não podem ser considerados mandatários ou representante da sociedade empresarial. Os Diretores, assim, atuariam como se fossem a própria companhia e a vontade da companhia é atribuída aos órgãos competentes.

Os Diretores atuam de forma autônoma dentro das competências atribuídas especificamente a eles pelo estatuto social. $\mathrm{O}$ estatuto, para prevenir responsabilidade de seus diretores, deveria fixar clara e minuciosamente as competências e poderes de cada diretor, definindo, ainda, a forma de atuação e disciplinando a organização interna da companhia e as funções de cada um de seus membros.

A representação da companhia poderá ser realizada individualmente por qualquer Diretor, caso não exista disposição em contrário no estatuto social. Nas sociedades mais complexas, o estatuto, além de definir as funções atribuídas a cada um dos Diretores, confere a representação da companhia perante terceiros ao Diretor-presidente em conjunto com outro Diretor. 
A previsão detalhada da organização interna das companhias, em especial nas grandes organizações empresariais com estrutura societária mais complexa é fundamental para evitar não apenas a sobreposição de funções e consequentes conflitos, como também para permitir a responsabilização pessoal dos Diretores pelas infrações cometidas, seja no âmbito penal, civil ou administrativo.

É por essa razão que organizações empresariais de maior porte, como é o caso das instituições financeiras, mantêm uma estrutura segmentada em que se encontram um Diretor jurídico, um Diretor financeiro, um Diretor para área de gestão de pessoas, um Diretor para marketing, um Diretor de relação com investidores, entre outros.

Nas empresas em que não existir Conselho de Administração, o estatuto poderá estabelecer que a diretoria delibere sobre assuntos de competência daquele órgão, como planejamento dos negócios e manifestações sobre determinados contratos. Não obstante, ainda que algumas matérias estejam sujeitas à deliberação colegiada da Diretoria, os Diretores são investidos legalmente de poderes para atuar individualmente.

Os Diretores poderão ser destituídos pelo Conselho de Administração, quando ele existir, e seus atos de gestão são supervisionados e fiscalizados por ele, embora não exista subordinação jurídica dos Diretores aos Conselheiros.

Nas estruturas mais complexas, é constante a figura do Diretor-presidente, também conhecido como CEO (Chief executive officer), elemento fundamental para a coordenação dos trabalhos da Diretoria e que, muitas vezes, atua como intermediador entre os Diretores, os membros do Conselho de Administração e os acionistas.

Para fins de atribuição de responsabilidade, os atos de outorga de mandato são realizados pelo Diretor na qualidade de representante orgânico da companhia e, portanto, seu afastamento, no entender de Nelson Eirizik ${ }^{165}$, não invalida ou torna ineficaz o mandato.

$\mathrm{Na}$ prática, os administradores usualmente contratam consultorias para serviços financeiros, jurídicos, de marketing, ambiental, com o objetivo de dar suporte técnico ou recomendação de melhores decisões a respeito de determinado assunto. Essas decisões são, contudo, tomadas pelos membros do Conselho ou Diretores, não sendo

${ }^{165}$ EIZIRIK, Nelson. A Lei das S/A comentada: arts. 121 a 188, cit., v. 2, p. 306. 
considerada delegação ilegal ou irregular de poderes. Os atos dos Diretores são, pois, limitados às competências atribuídas por lei, estatuto social e Conselho de Administração e, desde que praticados dentro desses moldes, sempre vincularão a companhia.

Os atos que extrapolarem as atribuições legais, estatutárias e do conselho de administração, em teoria, poderão ser anulados. Nesse sentido, um contrato assinado por diretor de uma companhia que o estatuto exige a assinatura de dois diretores, poderá ser objeto de anulação.

\subsubsection{Deveres dos administradores nas sociedades anônimas}

A Lei das Companhias contempla uma série de deveres dos administradores (membros do Conselho de Administração e Diretores). 1. Dever de diligência ${ }^{166}$ : exige que o administrador desempenhe sua função com empenho e cuidado no cumprimento do seu dever. É difícil de ser aferido e funciona como um princípio geral de direito que estabelece um padrão geral de conduta, sob o qual deve ser pautado todos os atos de gestão da companhia. A aplicação do dever de diligência é flexível e depende da verificação da natureza da atribuição do administrador e do caso concreto. Isto porque o zelo exigido de cada administrador depende do grau de acesso às informações ou conhecimento dos atos de gestão que esse administrador tenha na companhia. É uma obrigação de meio e não de resultado, ou seja, os administradores são obrigados a adotar todos os esforços para atingir um determinado resultado, que pode, apesar disso, não ocorrer. Assim, o administrador não terá violado o dever de diligência se não atingir as metas da organização empresarial, desde que tenha conduzido suas atividades com zelo e cuidado com vistas a atingir a consecução do objeto social e os lucros. A American Bar Association elaborou, com base em decisões dos Tribunais norte-americanos, o Guidebook of Directors ${ }^{167}$ na tentativa de estabelecer os parâmetros do dever de diligência. As principais recomendações são (i) os administradores

\footnotetext{
${ }^{166}$ Artigo 153 da Lei n. ${ }^{\circ}$ 6.404/1976: O administrador da companhia deve empregar, no exercício de suas funções, o cuidado e diligência que todo homem ativo e probo costuma empregar na administração dos seus próprios negócios.

${ }^{167}$ EIZIRIK, Nelson. A Lei das S/A comentada: arts. 121 a 188, cit., v. 2, p. 351-356.
} 
devem participar de todas as reuniões dos órgãos de administração, pessoalmente ou por telefone; (ii) os administradores devem analisar previamente todo o material fornecido sobre as questões a serem discutidas em reunião, devendo ponderar ainda se são suficientes para a convicção de sua formação; (iii) os administradores têm direito de confiar nos relatórios e estudos que lhe são fornecidos, desde que não tenham ciência de algum fato que os levem a não confiar; (iv) os administradores devem investigar eventuais problemas que lhe foram apontados e verificar se a Diretoria está tomando as melhores medidas para solucionar essas questões; e (v) os administradores devem informar os demais administradores de todos os fatos que consideram relevantes para tomada de decisões e para supervisão dos negócios da companhia.

2. Finalidade das atribuições e desvio de poder: exige que os administradores atuem dentro de suas funções legais e estatutárias, com o objetivo de atingir o fim social da companhia, com a maximização do retorno aos acionistas e investidores. Assim, embora a Lei das Sociedades Anônimas imponha que os administradores realizem o objeto social, eles devem fazê-lo ao menor custo possível, respeitando os direitos dos trabalhadores, as regras ambientais e as implicações tributárias. Embora possam ter sido eleitos por uma determinada classe ${ }^{168}$, os administradores não atuam como representantes desse grupo e também estão estritamente vinculados à consecução do objeto social da companhia, nos mesmos termos e com os mesmos deveres de todos os demais administradores. Dessa forma, qualquer deliberação que favoreça determinado grupo, sejam eles minoritários ou majoritários, constitui ato de desvio de poder e, por ele, o administrador pode ser responsabilizado. Assim, é considerado desvio de poder qualquer ato que, ainda que formalmente dentro dos limites legais e estatutários, não visa a atingir o interesse social ou a função social da empresa.

3. Dever de lealdade ${ }^{169}$ : é o padrão de conduta que visa a impedir as

\footnotetext{
${ }^{168}$ Esse é o caso dos membros do Conselho eleitos pelos acionistas minoritários ou os representantes dos empregados.

${ }^{169}$ Art. 155. O administrador deve servir com lealdade à companhia e manter reserva sobre os seus negócios, sendo-lhe vedado: I - usar, em benefício próprio ou de outrem, com ou sem prejuízo para a companhia, as oportunidades comerciais de que tenha conhecimento em razão do exercício de seu cargo; II - omitir-se no exercício ou proteção de direitos da companhia ou, visando à obtenção de vantagens, para si ou para outrem, deixar de aproveitar oportunidades de negócio de interesse da companhia; III - adquirir, para revender com lucro, bem ou direito que sabe necessário à companhia, ou que esta tencione adquirir. $\S 1^{\circ}$
} 
situações de conflito de interesse e evitar que o administrador dos ativos da companhia ou de informações confidenciais em seu próprio proveito. O artigo 155 da Lei n. ${ }^{\circ}$ 6.404/1976 estabelece o dever de servir com lealdade a companhia e atuar com discrição na gestão dos negócios e, ainda, prevê um rol não exaustivo de comportamentos vedados aos administradores $^{170}$.

\subsubsection{Responsabilidade civil dos administradores nas sociedades anônimas}

Como já assentado anteriormente, o direito societário brasileiro adotou a teoria organicista para justificar o vínculo existente entre sociedade empresária e seus administradores. Em decorrência disso, o administrador não é considerado mandatário ou representante legal da companhia. O administrador, assim, é nomeado e a ele são atribuídos poderes e deveres, definidos em lei ou no estatuto. O administrador é órgão social, isto é, a própria sociedade e todas as suas deliberações manifestadas são vontade da própria companhia. Sendo assim, o administrador responderá pessoalmente sempre que atuar em violação à lei ou ao estatuto. A responsabilidade civil tem por objetivo (i) a reparação de dano e a recomposição de patrimônio da companhia, bem como (ii) servir como instrumento de fiscalização dos atos dos administradores. A Lei das Sociedades Anônimas prevê que o administrador não será pessoalmente responsável perante terceiros por atos praticados em razão de gestão regular e, nesses casos, caso exista

\footnotetext{
Cumpre, ademais, ao administrador de companhia aberta, guardar sigilo sobre qualquer informação que ainda não tenha sido divulgada para conhecimento do mercado, obtida em razão do cargo e capaz de influir de modo ponderável na cotação de valores mobiliários, sendo-lhe vedado valer-se da informação para obter, para si ou para outrem, vantagem mediante compra ou venda de valores mobiliários. $\S 2^{\circ} \mathrm{O}$ administrador deve zelar para que a violação do disposto no $\S 1^{\circ}$ não possa ocorrer através de subordinados ou terceiros de sua confiança. $\S 3^{\circ}$ A pessoa prejudicada em compra e venda de valores mobiliários, contratada com infração do disposto nos $\S \S 1^{\circ}$ e $2^{\circ}$, tem direito de haver do infrator indenização por perdas e danos, a menos que ao contratar já conhecesse a informação. $\S 4^{\circ}$ É vedada a utilização de informação relevante ainda não divulgada, por qualquer pessoa que a ela tenha tido acesso, com a finalidade de auferir vantagem, para si ou para outrem, no mercado de valores mobiliários.

${ }^{170}$ Algumas situações em que o aproveitamento da oportunidade comercial é lícita, como nos casos em que a
Al companhia não tiver prejuízos com a situação seja porque (i) não tinha recursos para aproveitar a oportunidade ou (ii) a realização do negócio pela companhia não seja autorizado.
} 
algum prejuízo só a sociedade responde ${ }^{171}$.

A Lei n. ${ }^{\circ}$ 6.404/1976 também estabelece que os administradores responderão pessoalmente em duas situações, quais sejam: (i) quando agir com culpa ou dolo, ainda que em atue dentro dos limites da sua competência, e (ii) quando seus atos infringirem deveres atribuídos por lei ou o estatuto, desde que esses atos sejam praticados dentro de suas atribuições. Com isso, verifica-se que o direito societário adotou a responsabilidade civil subjetiva no artigo 158, I, da Lei da n. ${ }^{\circ}$ 6.404/1976, uma vez que exige, além do dano patrimonial e do nexo de causalidade, a intenção de causar dano (culpa ou dolo) do administrador. O inciso II do mesmo artigo 158, por sua vez, contempla responsabilidade de natureza objetiva, de sorte que, verificando-se hipótese de infração à lei ou ao estatuto, haverá presunção da culpa do administrador, com a subsequente inversão do ônus da prova; o administrador eximir-se-á de responsabilidade se comprovar que agiu com diligência e com o escopo de atingir o fim social da companhia. Na primeira hipótese, contudo, além do administrador, a organização empresarial também responderá pelos prejuízos; isto porque, com fundamento na teoria organicista, o administrador atua como órgão da companhia. Na hipótese de o administrador ter atuado com violação à lei ou ao estatuto, a companhia não estará obrigada a responder, com exceção das hipóteses de ratificação do ato faltoso, existência de vantagem para companhia ou quando prejudicado terceiros de boa-fé. Em todas essas situações, a companhia terá direito de regresso perante os administradores.

A responsabilidade dos administradores pelos seus atos faltosos, sejam eles praticados com culpa ou dolo em ato regular de gestão ou em violação a lei e estatuto, tem natureza individual e pessoal. A Lei das Companhias estabelece como exceções as hipóteses nas quais (i) o administrador não praticou o ato, mas tinha ciência e não adotou medidas para impedi-lo ou não foi diligente para tentar descobri-lo; (ii) não cumpriu o dever de garantir o funcionamento da companhia; ou (iii) não informou a assembleia geral sobre os atos faltosos de seu antecessor ou de outro administrador. Nelson Eizirik ${ }^{172}$

\footnotetext{
${ }^{171}$ Art. 158 da Lei n. ${ }^{\circ}$ 6.404/1976: O administrador não é pessoalmente responsável pelas obrigações que contrair em nome da sociedade e em virtude de ato regular de gestão; responde, porém, civilmente, pelos prejuízos que causar, quando proceder: I - dentro de suas atribuições ou poderes, com culpa ou dolo; II com violação da lei ou do estatuto.

${ }^{172}$ EIZIRIK, Nelson. A Lei das S/A comentada: arts. 121 a 188, cit., v. 2, p. 405-406.
} 
entende que o fato de o administrador integrar o mesmo órgão que outro administrador, ainda que esse órgão seja de deliberação colegiada, não é suficiente para que ele responda solidariamente pelos atos dos demais. O conselheiro poderá se eximir da responsabilidade desde que faça constar em ata seu voto contrário à deliberação ou, não sendo possível fazer constar na ata, informe formalmente o conselho de administração, o conselho fiscal e a assembleia geral ${ }^{173}$. Dos atos irregulares praticados pelos conselheiros fora da atuação do conselho de administração, contudo, não deflui a responsabilidade solidária dos demais membros do conselho, salvo se ficar comprovado que os demais conselheiros tinham ciência do ato ou que negligenciaram seus deveres permitindo que o ato ocorresse.

A diretoria não é órgão de deliberação colegiada e, em razão disso, os diretores têm poderes específicos e deveres autônomos, não existindo responsabilidade solidária entre eles. Ainda que o estatuto não atribua a divisão de funções não existe a solidariedade entre os diretores, salvo na hipótese em que for comprovado conluio entre eles, omissão ou negligência de um deles em relação aos atos dos outros. A Lei das Sociedades Anônimas ainda prevê a responsabilidade solidária dos diretores nos casos de violação das atribuições necessárias para garantir o funcionamento da companhia, como elaboração de demonstrações financeiras, convocação de assembleia geral, entre outros. Em companhias abertas, como se extrai da especialização das funções, responderá individualmente apenas o administrador com atribuição específica para cada matéria.

O conselho de administração, ainda, na qualidade de órgão fiscalizador da atividade de gestão dos diretores, responderá pelos atos ilícitos que chegaram a seu conhecimento ou quando não adotaram a diligência necessária para apurar um fato ou quando tiveram ciência e não tentaram impedi-lo. A doutrina tem preconizado que é necessário separar a responsabilidade dos conselheiros independentes dos conselheiros internos. Dessa forma, os conselheiros internos, caracterizados por aqueles que são Diretores ou acionistas da companhia, têm acesso mais detalhado a todas as informações

\footnotetext{
${ }^{173}$ Art.158, § $1^{\circ}$, da Lei n. ${ }^{\circ}$ 6.404/1976: O administrador não é responsável por atos ilícitos de outros administradores, salvo se com eles for conivente, se negligenciar em descobri-los ou se, deles tendo conhecimento, deixar de agir para impedir a sua prática. Exime-se de responsabilidade o administrador dissidente que faça consignar sua divergência em ata de reunião do órgão de administração ou, não sendo possível, dela dê ciência imediata e por escrito ao órgão da administração, no conselho fiscal, se em funcionamento, ou à assembleia-geral.
} 
da organização empresarial, enquanto o conselheiro independente somente terá acesso às informações e assuntos colocados em deliberação nas reuniões do Conselho e, com isso, não poderiam ser responsabilizados internamente na mesma medida que os conselheiros internos.

Por fim, a Lei n..$^{\circ}$ 6.404/1976 estabelece a possibilidade de ajuizamento de ação de responsabilidade pela companhia contra os administradores faltosos, com o fito de permitir a recomposição do patrimônio ou reparação dos prejuízos sofridos em razão dos atos irregulares. Essa ação poderá ser ajuizada pela companhia ou por acionistas diretamente, desde que verificadas hipóteses previstas na lei. $\mathrm{O}$ administrador poderá se eximir da responsabilidade perante a companhia e acionistas quando conseguir comprovar que agiu de boa-fé e com a finalidade de atingir o objeto social da companhia. 


\section{MODELOS DE IMPUTAÇÃO PENAL NAS ORGANIZAÇÕES EMPRESARIAIS}

\subsection{Considerações iniciais}

Nas sociedades empresariais rudimentares, particularmente naquelas de caráter familiar, composta de apenas dois ou três sócios, o problema da imputação penal não se impõe com tanta intensidade, podendo-se lançar mão das tradicionais ferramentas dogmáticas para a atribuição de responsabilidade penal. É que, nas sociedades mais simples, não se verifica uma pulverização das atividades empresariais, isto é, as atribuições de comandar ou ditar ordens e estabelecer diretrizes, coletar e repassar as informações e, finalmente, executar as ordens emanadas, pertencem à pessoas diversas.

De outro lado, a determinação da imputação penal de delitos perpetrados no âmbito das organizações empresariais sofisticadas emerge mais complexa, mormente em função da existência de diversos órgãos e instâncias de controle. Neste caso, o poder de decisão encontra-se disseminado e distribuído por intermédio de vários estamentos, verificando-se, em sua estrutura hierárquica, uma constante divisão do trabalho e uma dinâmica delegação e coordenação das diversas funções existentes na organização.

Como observa Schünemann, a forma de organização das sociedades empresárias modernas, marcada pela hierarquia no plano vertical e pela divisão de funções no plano horizontal, conduz, como consequência de uma imputação jurídico-penal tradicional, de perfil individualizador, a uma "irresponsabilidade organizada de todos"174.

\footnotetext{
${ }^{174}$ SCHÜNEMANN, Bernd. Las prescripciones sobre la autoría en la ley boliviana sobre la base de las modificaciones al código penal del 10 de marzo de 1997 y sus consecuencias para la responsabilidad de los órganos de las empresas: ¿un modelo para latinoamérica? In: Obras. 1. ed. Santa Fe: RubinzalCulzoni, 2009. (Colección Autores de Derecho Penal, t. 2, p. 201; LINARES ESTRELLA, Ángel. Un problema de la parte general del derecho penal económico: el actuar en nombre de otro, análisis del derecho penal español y cubano. Granada: Editorial Comares, 2002. p. 144 e ss.; no mesmo diapasão, afirmando ser um "erro" interpretar sob o prisma estritamente individual o sentido objetivo de alguns comportamentos praticados em organizações complexas: FEIJOO SÁNCHEZ, Bernardo. Derecho penal de la empresa e imputación objetiva. Madrid: Reus, 2007. p. 124.
} 
Esse ponto torna-se ainda mais problemático quando detectamos que um fato criminoso, uma vez dividido na sua estrutura, revela ter ele sido resultado de uma série de ações praticadas por várias pessoas sem que cada conduta individualmente considerada possa ser considerada delituosa. Imaginemos, por exemplo, um crime contra as relações de consumo, em que o Conselho de Administração de uma Sociedade Anônima decide, pelo voto unânime dos conselheiros “ $\underline{A}$ ”, “ $\underline{B}$ ”, “ $\underline{C}$ ” e " $\underline{D}$ ”, cortar os gastos de um determinado produto alimentício através da adição de uma substância nova chamada " $\underline{T}$ ", que substitui outra, de nome " $\underline{P}$ ", de valor mais alto, visando, com isso, aumentar os lucros. Não obstante, existem diversos estudos técnicos indicando que substância " $\underline{T}$ ", ainda sob teste, é potencialmente prejudicial à saúde dos consumidores. A decisão de substituição da substância " $P$ " foi comunicada ao departamento de vendas da companhia, formado pelas pessoas de " $\underline{ }$ " e " $\underline{Z}$ " que, a seu turno, determinaram que os funcionários " $\underline{M}$ " e " $\underline{O}$ " modificassem os rótulos da embalagem do produto, omitindo os dizeres sobre a nocividade do produto. A hipótese conduz, evidentemente, ao crime do artigo 63 do Código de Defesa do Consumidor ${ }^{175}$. Se a conduta for desdobrada em etapas, verificar-se-á, em princípio, que somente os funcionários " $\underline{M}$ " e " $\underline{O}$ " executaram o núcleo verbal do tipo, conquanto não tivessem conhecimento do potencial lesivo da substância " $\underline{T}$ ”, ou seja, somente cumpriram as ordens emanadas pelo departamento de vendas da companhia, composto por " $\underline{X}$ " e " $\underline{Z}$ ", os quais, a seu turno, transmitiram o conteúdo da decisão adotada pelos conselheiros " $\underline{A}$ ", “ $\underline{B}$ ", “ $\underline{C}$ ” e “ $\underline{D}$ ”. Cada comportamento concorreu para a consumação do crime, mas, se observado de maneira isolada, à exceção dos funcionários " $\underline{M}$ " e " $\underline{O}$ ", ele não encontra descrição no tipo penal delineado no artigo 63 do Código de Defesa do Consumidor.

Dessa forma, a questão a ser enfrentada radica em constatar de quem é a responsabilidade penal ou, mais precisamente, sobre quem deve recair a imputação penal pelo crime praticado por intermédio da pessoa jurídica que exerce a atividade de empresa.

Sob esse contexto, emerge da doutrina uma enorme variedade de soluções sugeridas para resolver o problema da imputação penal. De um lado, existem aqueles que defendem que os crimes perpetrados por intermédio da pessoa jurídica sejam imputados somente aos executores materiais, em razão da constatação de uma inequívoca autoria

\footnotetext{
${ }^{175}$ Art. 63. Omitir dizeres ou sinais ostensivos sobre a nocividade ou periculosidade de produtos, nas embalagens, nos invólucros, recipientes ou publicidade: Pena - Detenção de seis meses a dois anos e multa.
} 
imediata. De outro lado, acena-se com a necessidade de responsabilização dos membros dos escalões intermediários, vislumbrando-se, neste caso, uma situação de participação; por fim, defende-se a imputação das pessoas físicas que compõem os órgãos de direção.

Este último caso apresenta, sem dúvida, o setor mais controvertido e o que, consequentemente, tem servido de palco para as mais diversas discussões doutrinárias. Com efeito, o pano de fundo sobre o qual se trava o debate compõe-se pela admissão de que (i) deve ser evitada a responsabilização exclusiva do executor, isto é, aquele que ocupa o patamar mais baixo na estrutura empresarial, deixando-se impunes os agentes que controlam a organização empresarial ${ }^{176}$ e de que (ii) é inadequada a tendência implícita proveniente da teoria objetivo-formal da autoria ${ }^{177}$ de caracterizar os membros dos órgãos de direção da sociedade empresária como meros partícipes por indução dos fatos cometidos pelos seus subordinados, os quais serão considerados autores imediatos ${ }^{178}$.

Jesús-María Silva Sánchez propõe, então, duas abordagens através das quais a imputação de fatos penais cometidos no interior das organizações empresariais pode ser estudada. A primeira diz respeito aos delitos comuns levados a efeito comissivamente pelos membros responsáveis pela condução da organização empresarial. A segunda relaciona-se à atribuição de responsabilidade dos integrantes dos órgãos diretivos nos casos de delitos especiais, isto é, aqueles que exigem determinadas condições, qualidades ou relações que concorrem formalmente somente na sociedade empresária e não nos seus órgãos ${ }^{179}$.

Esse segundo caso é especialmente importante para o Direito Penal Econômico, chegando a representar, como aponta Carlos Martínez-Buján Pérez, a principal diferença para o Direito Penal "clássico", ou "nuclear", para usarmos a expressão de Silva

\footnotetext{
${ }^{176}$ LINARES ESTRELLA, Ángel. Un problema de la parte general del derecho penal económico: el actuar en nombre de otro, análisis del derecho penal español y cubano, cit., p. 144.

${ }^{177}$ Segundo a qual autor será aquele que executa, total ou parcialmente, a conduta que realiza o tipo penal (DIAS, Jorge de Figueiredo. Direito penal: parte geral: questões fundamentais: a doutrina geral do crime, cit., p. 759).

${ }^{178}$ FEIJOO SÁNCHEZ, Bernardo. Derecho penal de la empresa e imputación objetiva, cit., p. 156.

${ }^{179}$ SILVA SÁNCHEZ, Jesús María. Responsabilidad penal de las empresas y de sus órganos en derecho español. Responsabilidade penal da pessoa jurídica: em defesa do princípio da imputação penal subjetiva. 2. ed. São Paulo: Ed. Revista dos Tribunais, 2010. p. 65.
} 
Sánchez ${ }^{180}$, porquanto este tem como regra geral a existência de tipos comuns, que não exigem do sujeito ativo uma especial qualidade de fato ou de direito ${ }^{181}$.

Esse panorama determina que penetremos no âmago da sociedade empresária e conheçamos a sua estrutura organizativa para a adequada formulação da imputação penal ${ }^{182}$. A atribuição pessoal de responsabilidade penal no ambiente coletivo empresarial impõe que verifiquemos, preliminarmente, como de que modo a sociedade foi estruturada, quais são os seus patamares hierárquicos, como funciona a dinâmica de divisão de atribuições e a delegação de funções, enfim, como funciona a organização.

Sempre partindo do princípio que a responsabilidade penal deverá recair sobre as pessoas físicas que, de algum modo, intervieram no evento criminoso praticado no contexto da organização empresarial, optamos por empreender o estudo dos modelos de imputação penal nas organizações empresariais em dois grupos diferenciados em razão da natureza da conduta ${ }^{183}$. O primeiro grupo diz respeito aos casos de atribuição de responsabilidade penal aos componentes dos órgãos que comandam a organização empresarial pelo cometimento de condutas comissivas; no segundo grupo serão analisados os fatos criminosos praticados por intermédio de condutas omissivas nas quais houve o descumprimento de um dever de garante na forma do artigo $13, \S 2^{\circ}$, do Código Penal.

\subsection{Imputação penal em razão de condutas comissivas}

A imputação penal de fatos cometidos mediante um comportamento positivo do agente (comissão) não tem suscitado muita controvérsia na doutrina, desde que se trate

\footnotetext{
${ }^{180}$ SILVA SÁNCHEZ, Jesús María. La expansión del derecho penal: aspectos de la política criminal en las sociedades postindustriales, cit., p. 178 e ss.

${ }^{181}$ MARTÍNEZ-BUJÁN PÉREZ, Carlos. Derecho penal económico y de la empresa: parte general. 2. ed. Valencia: Tirant lo Blanch, 2007. p. 489.

${ }^{182}$ MONTANER FERNÁNDEZ, Raquel. Gestión empresarial y atribución de responsabilidad penal: a propósito de la gestión medioambiental. Barcelona: Atelier, 2008. p. 42-43.

${ }^{183}$ Optamos, pois, pela exclusiva abordagem dos critérios de atribuição de responsabilidade penal extraídos da Parte Geral, de sorte que outros instrumentos do sistema penal, como a utilização de técnicas legislativas de tipificação de crimes de perigo abstrato, crimes culposos e crimes omissivos próprios não será objeto de investigação (GARCÍA CAVERO, Percy. Derecho penal económico: parte general. 2. ed. Lima: Ed. Jurídica Grijley, 2007. t. 1, p. 692-695).
} 
de crime comum, que não exige do sujeito ativo especial qualidade de fato ou de direito ${ }^{184}$.

Assim, se o delito (comissivo) cometido diretamente pelo subordinado for uma consequência de um plano desenvolvido pelos membros do órgão de comando da organização empresarial, ou, quando menos, de uma situação de provocação ou de favorecimento, a imputação penal será realizada em conformidade com as regras de atribuição de responsabilidade em matéria de autoria e de concurso de pessoas ${ }^{185}$.

No Direito Penal brasileiro a distinção entre autor e partícipe pode parecer, em princípio, desnecessária, haja vista que o legislador foi partidário, ao redigir o artigo 29 do Código Penal, da teoria unitária ou monista ${ }^{186}$, que considera autor todo aquele que, de qualquer modo, concorre para o evento criminoso, não discutindo, no plano do injusto, se essa concorrência foi preponderante ou acessória. Em outros termos: pela aplicação automática do artigo 29 do Código Penal brasileiro, a verificação da condição jurídica da intervenção do agente no crime emergiria ociosa, irrelevante, resolvendo-se a questão da imputação penal exclusivamente com a teoria da equivalência dos antecedentes causais.

Essa solução, contudo, revela-se profundamente insatisfatória e, mesmo intuitivamente, chega a conflitar com a ideia de justiça material ${ }^{187}$, porque trata todos os sujeitos que tomam parte do delito da mesma maneira, equiparando desiguais aos iguais.

Como observa Luís Greco, a distinção dos patamares ou graus de intervenção criminal se mostra necessária sob o aspecto dogmático, porque o próprio Código Penal, em várias passagens, distingue autor de partícipe ${ }^{188}$. Sob o aspecto jurídico, a diferenciação também é imprescindível em razão do postulado do nullum crimen, nulla

\footnotetext{
${ }^{184}$ SILVA SÁNCHEZ, Jesús María. Responsabilidad penal de las empresas y de sus órganos en derecho español. Responsabilidade penal da pessoa jurídica: em defesa do princípio da imputação penal subjetiva. 2. ed. São Paulo: Ed. Revista dos Tribunais, 2010. p. 76.

${ }^{185}$ MARTÍNEZ-BUJÁN PÉREZ, Carlos. Derecho penal económico y de la empresa: parte general, cit., p. 494.

${ }^{186}$ HUNGRIA, Nélson. Comentários ao Código Penal, cit., v. 1, t. 2, p. 409 e ss.; COSTA JR., Paulo José da. Curso de direito penal, cit., p. 136; FRAGOSO, Heleno Cláudio. Lições de direito penal: a nova parte penal, cit., p. 262; FERRAZ, Esther de Figueiredo. A co-delinquência no direito penal brasileiro. São Paulo: Bushatsky, 1976. p. 34 e ss.

${ }^{187}$ Como adverte Fragoso, se "a lei não distingue entre autor e partícipe (em sentido estrito), considerando coautores todos quantos concorrem para a ação delituosa, tal distinção, no entanto, está na natureza das coisas e não pode ser desconhecida pela doutrina, pois dela resultam consequências jurídicas" (FRAGOSO, Heleno Cláudio. Lições de direito penal: a nova parte penal, cit., p. 263).

${ }^{188}$ Luís Greco exemplifica com o artigo 122 do Código Penal, que tipifica o crime de induzimento, instigação ou auxílio ao suicídio: "induzir ou instigar alguém a suicidar-se ou prestar-lhe auxílio para que o faça" (GRECO, Luís. Cumplicidade através de ações neutras: a imputação objetiva na participação, cit., p. 11-12).
} 
poena sine lege, na medida em que, ao não se apartar os conceitos de autoria e de participação, estar-se-ia dissolvendo o tipo penal e as descrições de ações nele contidas ${ }^{189}$.

Demais disso, acrescentaríamos outro inconveniente para a manutenção do conceito unitário e extensivo de autor, embora de índole processual penal: constitui emanação do direito de ampla defesa o conhecimento, pelo acusado, de todas as circunstâncias da imputação penal contra ele formulada, ou seja, ele tem o direito constitucional de saber se responde à acusação como autor ou como partícipe do delito.

Parece fora de dúvida, portanto, a importância de estabelecer, com correção, qual o papel de cada agente no contexto do delito, até porque, como dispõe o artigo 31 do Código Penal brasileiro, o ajuste, a determinação ou instigação e o auxílio, salvo disposição em contrário, não são puníveis, se o crime não chega, pelo menos, a ser tentado.

Assim, para os fins propostos no presente trabalho, utilizar-nos-emos da distinção entre autor e participe, acrescentando, para tanto, que a participação poderá ocorrer mediante instigação, hipótese na qual o agente cria ou incute na cabeça de outrem a ideia criminosa, ou mediante cumplicidade, situação na qual existirá auxílio ou facilitação, material ou psíquica, para que o autor principal realize o crime ${ }^{190}$.

\subsubsection{Autoria imediata no âmbito da organização empresarial}

Em se tratando de delitos comuns levados a efeito em ambientes organizacionais, com hierarquia e divisão de tarefas entre seus componentes, a qualificação jurídica daquele que diretamente executa o fato resolver-se-á por intermédio de autoria

\footnotetext{
${ }^{189}$ GRECO, Luís. Cumplicidade através de ações neutras: a imputação objetiva na participação, cit., p. 11-12; BOLEA BARDON, Carolina. Autoría mediata en derecho penal. Valencia: Tirant lo Blanch, 2000. p. 142 e ss.

${ }^{190}$ GRECO, Luís. Cumplicidade através de ações neutras: a imputação objetiva na participação, cit., p. 6. Ressalva Luís Greco, no ponto, que, ao contrário de algumas manifestações na doutrina brasileira, "a distinção entre cumplicidade e instigação não está em ser a primeira física e a segunda psíquica”, mas no fato de que o instigador "provoca uma decisão de praticar o fato, e daí porque sua conduta é bem mais grave do que a daquele que meramente contribuiu" (Id. Ibid., p. 6); Também: BATISTA, Nilo. Concurso de agents: uma investigação sobre os problemas da autoria e da participação no direito penal brasileiro. 4. ed. Rio de Janeiro: Lumen Juris, 2008. p. 157 e ss.
} 
imediata ou da coautoria, a depender das circunstâncias do caso concreto ${ }^{191}$. Em relação aos membros do órgão diretivo que determinaram ao subalterno a prática da conduta criminosa, cogitar-se-á, em princípio, de participação por instigação ou cooperação necessária ${ }^{192}$.

Imagine-se, por exemplo, o caso do funcionário do setor de transporte de uma sociedade empresária de nome " $\underline{X}$ ” que, atendendo às ordens do gerente " $\underline{Y}$ ”, despeja no leito de um rio material tóxico resultante da atividade de empresa. Descobre-se, posteriormente, que essa conduta acarretou a mortandade de diversos animais, caracterizando-se, por conseguinte, o crime do artigo 54 da Lei n. ${ }^{\circ} 9.605 / 1998^{193}$. " $\underline{Y}$ " tinha conhecimento direto do potencial tóxico da substância descartada, pois teve acesso a estudos técnicos que assinalavam expressamente essa circunstância. A seu turno, " $\underline{X}$ " suspeitava que a substância fosse tóxica, uma vez que ouviu vários boatos nesse sentido dentro da pessoa jurídica e porque também viu animais mortos ao longo do leito do rio.

A hipótese ilustrada indica que " $\underline{X}$ " praticou o crime do artigo 54 da Lei n." 9.605/1998 na condição de autor imediato. Embora suspeitasse que a substância fosse tóxica, continuou a realizar a conduta, assumindo o risco de produzir o resultado (morte dos animais), agindo, assim, como dolo eventual. O gerente " $\underline{Y}$ " ordenou que " $\underline{\text { " }}$ realizasse o comportamento criminoso, incutindo em sua cabeça o desiderato criminoso. “ $\underline{Y}$, portanto, será partícipe por instigação, visto que não realizou qualquer ato de execução do delito ambiental, embora intuitivamente se possa afirmar que a intervenção de “ $\underline{Y}$ ” na concretização do evento criminoso foi bem mais acentuada do que a de " $\underline{X}$ ".

A consideração daqueles que ocupam o ápice da organização empresarial por delitos determinados aos subordinados como meros instigadores causa perplexidade, porque a conduta deles não traduz, propriamente, um comportamento de caráter acessório ou secundário ${ }^{194}$, que são características inerentes à participação ${ }^{195}$. Por isso, destaca Ángel

\footnotetext{
${ }^{191}$ SILVA SÁNCHEZ, Jesús María. Responsabilidad penal de las empresas y de sus órganos en derecho español. Responsabilidade penal da pessoa jurídica: em defesa do princípio da imputação penal subjetiva, cit., p. 77.

${ }^{192}$ Id. Ibid., p. 77.

${ }^{193}$ Art. 54. Causar poluição de qualquer natureza em níveis tais que resultem ou possam resultar em danos à saúde humana, ou que provoquem a mortandade de animais ou a destruição significativa da flora: Pena reclusão, de um a quatro anos, e multa.

${ }^{194}$ MARTÍNEZ-BUJÁN PÉREZ, Carlos. Derecho penal económico y de la empresa: parte general, cit., p. 494.

${ }^{195}$ SANTOS, Juarez Cirino dos. Direito penal: parte geral, cit., p. 368; BATISTA, Nilo. Concurso de agents: uma investigação sobre os problemas da autoria e da participação no direito penal brasileiro, cit., p. 162.
} 
Linares Estrella que essa "transferência de responsabilidade penal" para o setor mais baixo e mais fragilizado, diga-se de passagem, da estrutura hierarquizada da sociedade empresária acarreta um menoscabo à eficácia preventiva do Direito Penal ${ }^{196}$, pois os funcionários que executam diretamente as ordens de seus patrões raramente conhecem o potencial delitivo de seus próprios atos. Além disso, dentro da hierarquia da organização empresarial o subordinado tem limitada sua capacidade de resistência para antepor-se às ordens superiores. Dessa circunstância, aliás, derivaria, para Linares Estrella, a fungibilidade dos subordinados, ou seja, a possibilidade deles serem substituídos em caso de recusa do cumprimento da determinação delituosa ${ }^{197}$.

Diante desse quadro, tem sido proposta a utilização da atribuição de responsabilidade penal dos membros dos órgãos de controle do ente empresarial através da autoria mediata, sob o argumento de que eles deteriam inegavelmente o domínio do fato.

\subsubsection{Autoria mediata no âmbito da organização empresarial}

A ideia central da teoria do domínio do fato é a de que, para ostentar a condição de autor, o agente deve ser o protagonista da ação típica. Ao realizar a ação criminosa, o indivíduo se coloca no centro do acontecer típico e isso lhe confere o domínio do fato ${ }^{198}$. Em conformidade com Claus Roxin, o domínio do fato pode se manifestar de três formas: (i) domínio da ação; (ii) domínio funcional do fato; e (iii) domínio da vontade $^{199}$. O domínio da ação enseja o aparecimento da autoria imediata, pois o agente controla a própria conduta. O domínio funcional do fato diz respeito à coautoria, existindo a planificação de uma conduta e a divisão de funções na prática delitiva. O domínio da vontade refere-se àquela situação na qual o sujeito, que está por trás, utiliza um terceiro, denominado instrumento, para que este cometa o crime. Esta última situação proporciona o aparecimento de uma autoria mediata do agente.

\footnotetext{
${ }^{196}$ LINARES ESTRELLA, Ángel. Un problema de la parte general del derecho penal económico: el actuar en nombre de otro, análisis del derecho penal español y cubano, cit., p. 144.

${ }^{197}$ Id. Ibid., p. 144.

${ }^{198}$ ROXIN, Claus. Autoría y dominio del hecho en derecho penal. 7. ed. Madrid: Marcial Pons, 2000. p. 163.

${ }^{199}$ Id. Ibid., p. 149.
} 
Claus Roxin identificou três formas nas quais pode existir o domínio da vontade do instrumento sem que o autor (mediato) esteja presente no momento da execução da figura típica: (i) por coação do executor; (ii) enganando-se o executor; (iii) por ordens através de um aparato organizado de poder. Nas duas primeiras hipóteses, o sujeito que realiza concretamente a conduta típica (executor ou autor imediato), atua com a sua capacidade de discernimento alterada, diminuída ou mesmo eliminada, em razão da coação ou do erro ${ }^{200}$ a que foi submetido. Na terceira forma o executor comporta-se com dolo, detém conhecimento pleno do caráter ilícito de sua conduta, sendo penalmente responsável por seus atos ${ }^{201}$. Esta modalidade, materializada através de aparatos organizados de poder, é a mais controvertida na formulação teórica de Roxin, pois admite a existência de um instrumento (autor imediato) com plena responsabilidade, ao contrário dos demais casos.

Concebida originariamente por Roxin para os casos de violência estatal, organizações criminosas e organizações terroristas, a autoria mediata por intermédio de aparatos organizados de poder tem sido objeto de frequente discussão dentro e fora da Alemanha, por constituir, para a jurisprudência do Tribunal Federal Alemão (Bundesgerichtshof) e para um considerável, embora ainda minoritário setor doutrinário, um veículo de imputação penal hábil à consideração da autoria mediata na criminalidade de empresa $^{202}$. Esse tema, contudo, dada a sua importância para o desenvolvimento do presente trabalho, será objeto de específico estudo no Capítulo V (Os aparatos organizados de poder).

As hipóteses de coação e erro têm efetivamente ensejado situações nas quais a doutrina entreveja autoria mediata no ambiente da criminalidade de empresa. De fato, em virtude do perfil hierárquico que delineia a sociedade, frequentemente as ordens emanadas do órgão de comando chegam aos empregados sem que eles conheçam o conteúdo

\footnotetext{
${ }^{200}$ Claus Roxin escalona as categorias de erro nos seguintes termos: (i) o agente que erra de modo não doloso e sem culpa ou com imprudência inconsciente; (ii) o que realiza o tipo com imprudência consciente; (iii) o que executa a conduta dolosamente, mas sem consciência da antijuridicidade, (iv) ou com suposição errônea de um fato que exclui a culpabilidade; (v) o agente pratica conduta típica, antijurídica e culpável, apesar do erro; (vi) o executor realiza o evento que em sua pessoa é atípico ou lícito (Id. Ibid., p. 194).

${ }^{201}$ FERNÁNDEZ IBÁÑEZ, Eva. La autoría mediata en aparatos organizados de poder. Granada: Editorial Comares, 2006. p. 10. Em contrapartida, esse é, talvez, o ponto mais criticado da formulação teórica de Claus Roxin, como será visto oportunamente.

${ }^{202}$ Sob esse prisma Roxin tem sustentado que, fora dos casos de aparatos organizados de poder, o chefe de um grupo criminoso e - por identidade de razões - os diretores de uma organização empresarial não podem ser tratados como autores mediatos, mas como instigadores ou, se eles dirigirem ou a abranger a execução do crime, como coautores (ROXIN, Claus. Autoría y dominio del hecho en derecho penal, cit., p. 330).
} 
antijurídico e o alcance lesivo da diretiva. Isso mais se agrava em termos de imputação quando se tem presente que a ordem visando à realização de alguma conduta no seio da organização passa por diversos degraus intermediários antes de chegar ao destinatário ${ }^{203}$.

A coação a que foi submetido o subordinado pode ocorrer, segundo observam David Baigún e Salvador Darío Bergel, naquelas situações que revelam ameaças concretas ou uma extrema dependência psíquica do empregado, que corre o risco de ser demitido se não realizar a conduta criminosa idealizada pelos seus superiores hierárquicos ${ }^{204}$. Neste caso, porém, Baigún e Bergel advertem que será importante analisar se o caso indica, de fato, uma coação ou um temor de escassa intensidade, hipótese em que a autoria mediata restará descaracterizada, abrindo espaço para a participação criminosa ${ }^{205}$.

De outro lado, o erro suscitado no subordinado apto a gerar autoria mediata será aquele incidente sobre os elementos do tipo penal (erro de tipo) ou mesmo sobre a dúvida $^{206}$ acerca da existência da norma de proibição (erro de proibição direto) ou da existência da vigência de alguma causa justificante ou tipo permissivo (erro de proibição indireto ${ }^{207}$. Aqui, contudo, se faz necessária uma ressalva. É que a autoria mediata na hipótese do sujeito que atua em erro de proibição é admitida majoritariamente pela doutrina desde que o erro seja qualificado como invencível, havendo discussão quando o autor imediato ou executor encontrar-se numa situação deflagradora de erro vencível ${ }^{208}$.

Nesse passo, é importante esclarecer que esses casos de erro dizem respeito à figura do autor imediato, ao subalterno que, agindo enquanto instrumento, concretamente executa o fato criminoso. A advertência tem sua razão de ser porque, como observa Juarez Cirino dos Santos, o erro também pode recair sobre a pessoa do autor mediato. Neste caso,

${ }^{203}$ ILHARRESCONDO, Jorge Marcelo. Delitos societarios. 1. ed. Buenos Aires: La Ley, 2008. p. 126.

${ }^{204}$ BAIGÚN, David, DARÍO BERGEL, Salvador. El fraude en la administración societaria. Buenos Aires: Depalma, 1991. p. 179; ILHARRESCONDO, Jorge Marcelo. Delitos societarios, cit., p. 132.

${ }^{205}$ BAIGÚN, David, DARÍO BERGEL, Salvador. El fraude en la administración societaria, cit., p. 180.

${ }^{206}$ LEITE, Alaor. Dúvida e erro sobre a proibição no direito penal: a atuação nos limites entre o permitido e o proibido. São Paulo: Atlas, 2013. p. 121 e ss.

${ }^{207}$ ILHARRESCONDO, Jorge Marcelo. Delitos societarios, cit., p. 130. Como exemplo típico de autoria mediata no seio da organização por erro de tipo do instrumento, David Baigún e Salvador Darío Bergel indicam o caso do funcionário que se apropria de recursos a pedido do administrador de uma instituição sem saber que os recursos têm um destino fraudulento; neste caso, os Baigún e Bergel assinalam que, por atuar sem dolo, remanesce exclusivamente a responsabilidade penal do autor mediato (BAIGÚN, David, DARÍO BERGEL, Salvador. El fraude en la administración societaria, cit., p. 180).

${ }^{208}$ BOLEA BARDON, Carolina. Autoría mediata en derecho penal, cit., p. 202-203; BAIGÚN, David, DARÍO BERGEL, Salvador. El fraude en la administración societaria, cit., p. 180 e ss. 
em que existe a falsa interpretação sobre características que fazem do autor imediato instrumento nas mãos do autor mediato, exclui-se o domínio do fato ${ }^{209}$.

No contexto do Direito Penal brasileiro, Nilo Batista aponta quatro casos de autoria mediata previstas no Código Penal, todas derivadas exclusivamente de erro ou coação que sugerem a possibilidade concreta de autoria mediata no âmbito dos delitos empresariais, a saber: (i) caso de erro determinado por terceiro (art. 20, $\S 2^{\circ}$ ); (ii) o caso de coação irresistível (art. 22); (iii) o caso de obediência hierárquica (art. 22); (iv) o caso de instrumento impunível em virtude de condição ou qualidade pessoal (art. 62, III) ${ }^{210}$.

Entretanto, é imperioso destacar que a proposta, no plano vertical, de autoria mediata para os membros do órgão de direção não se aplica de modo abrangente, encontrado limites nos crimes de mão própria ou de atuação pessoal, em que a execução do fato somente pode ser obra do agente que executa pessoalmente a conduta e nos crimes de forma vinculada, nos quais a lei descreve a atividade que conduz ao crime de modo particularizado $^{211}$.

\subsubsection{Coautoria no âmbito da organização empresarial}

A configuração das sociedades empresárias, em especial aquelas mais complexas, como as companhias, em que o poder de controle é exercido por órgão ou órgãos compostos por diversas pessoas, faz com que, no plano horizontal, seja comum a figura da coautoria. Modernamente, com o acolhimento da teoria do domínio do fato, a coautoria consubstancia uma expressão do domínio funcional do fato e se corporifica juridicamente mediante a resolução comum de uma conduta e a divisão de funções ${ }^{212}$.

\footnotetext{
${ }^{209}$ Transformando-se o autor mediato em instigador. SANTOS, Juarez Cirino dos. Direito penal: parte geral, cit., p. 350-351. Também BRUNO, Aníbal. Direito penal: parte geral, cit., t. 2, p. 179.

${ }^{210}$ BATISTA, Nilo. Concurso de agents: uma investigação sobre os problemas da autoria e da participação no direito penal brasileiro, cit., p. 135.

${ }^{211}$ MARTÍNEZ-BUJÁN PÉREZ, Carlos. Derecho penal económico y de la empresa: parte general, cit., p. 498.

${ }^{212}$ ROXIN, Claus. Autoría y dominio del hecho en derecho penal, cit., p. 308 e ss.
} 
$\mathrm{Na}$ coautoria, cada um dos intervenientes ostenta, sob o contexto do fato criminoso, uma posição chave, para usar a terminologia de Roxin, e somente pode levar a cabo o plano atuando conjuntamente, conquanto cada um possa anular o plano comum retirando a intervenção ${ }^{213}$. Nesse sentido, tem-se o exemplo do titular da organização empresarial que codecide com seus subordinados a realização de um fato delitivo, evidenciando, com isso, um codomínio funcional do fato por todos que nele intervém na fase executiva para a sua realização ${ }^{214}$.

Essa situação se revela profundamente relevante no ambiente corporativo em função do desmembramento ou da pulverização do poder de controle empresarial. Com efeito, a contribuição para a conduta criminosa no interior de órgãos colegiados pode ocorrer expressamente, mediante manifestação de vontade exarada no voto, ou, ainda, com a simples presença para a composição do quórum necessário à deliberação societária ${ }^{215}$.

Nos casos em que a concepção de um ou mais crimes foi decidida pelos votos dos membros do órgão colegiado (homem de trás) da alta administração da organização empresarial, Francisco Muñoz Conde propõe a existência de uma coautoria que prescinde da intervenção do coautor na fase executiva do delito ${ }^{216}$. Para Muñoz Conde, em se tratando de criminalidade econômica, impõe-se a mitigação do requisito da execução conjunta, típico dos crimes contra a vida, contra a liberdade e contra o patrimônio, e a adoção de uma nova perspectiva lastreada na ideia de "por em marcha" a decisão com potencial delitivo ${ }^{217}$. Assim, o domínio do fato que fundamenta a coautoria incidiria, inclusive, na fase preparatória do crime, desde que a conduta do dirigente esteja moldada à execução do delito ou ligada intimamente a $e^{218}$. É que, nesta hipótese, recorda Klaus Tiedemann, tendo em vista o fato que o executor pertence à organização sob cujo contexto o delito foi cometido, dar-se-ia uma vinculação objetiva que ultrapassaria a vinculação

\footnotetext{
${ }^{213}$ ROXIN, Claus. Autoría y dominio del hecho en derecho penal, cit., p. 309.

${ }^{214}$ LINARES ESTRELLA, Ángel. Un problema de la parte general del derecho penal económico: el actuar en nombre de otro, análisis del derecho penal español y cubano, cit., p. 151.

${ }^{215}$ ILHARRESCONDO, Jorge Marcelo. Delitos societarios, cit., p. 99.

${ }^{216}$ Contrariando, nesse ponto, a doutrina do domínio funcional do fato tal como concebida por Claus Roxin.

${ }^{217}$ MUÑOZ CONDE, Francisco. Problemas de autoría y participación en el derecho penal económico, o ¿cómo imputar a título de autores a las personas que sin realizar acciones ejecutivas, deciden la realización de un delito en el ámbito de la delincuencia económica empresarial? Revista Penal, Salamanca, n. 9, p. 82, ene. 2002.

${ }^{218}$ Id. Ibid., p. 83.
} 
subjetiva emanada, pela ideia tradicional do domínio do fato, do acordo de agentes ${ }^{219}$.

Ao descartar a ideia de domínio de vontade em razão de um aparato, Muñoz Conde dedica-se ao tratamento da existência de responsabilidade do instrumento nos seguintes termos: se ele for irresponsável, haverá coautoria mediata; se responsável, ou seja, afastada sua condição de instrumento do autor, dar-se-á uma coautoria normal ${ }^{220}$.

\subsubsection{A imputação da autoria nos crimes comissivos especiais}

Outra ordem de delitos que não raramente surgem no seio das organizações empresariais relaciona-se aos denominados crimes especiais ou próprios, em que o tipo penal perpetrado no ambiente empresarial exige determinadas condições ou qualidades do sujeito ativo $^{221}$ que concorrem somente na sociedade empresária e não em seus órgãos ${ }^{222}$.

Em se tratando de crime especial, quem não empolgar a qualidade de fato ou de direito exigida pelo tipo somente pode ser tratado como coautor ou partícipe ${ }^{223}$. Exemplos típicos de crimes especiais no ordenamento jurídico encontram-se nos delitos funcionais, praticados contra a Administração Pública, pois somente quem enverga a qualidade de funcionário, prevista no artigo 327 do Código Penal ${ }^{224}$, pode concretizá-lo ${ }^{225}$.

\footnotetext{
${ }^{219}$ TIEDEMANN, Klaus. Derecho penal económico: introducción y parte general. Perú: Editorial Grijley, 2009. p. 231.

${ }^{220}$ MUÑ̃Z CONDE, Francisco. Problemas de autoría y participación en el derecho penal económico, o ¿cómo imputar a título de autores a las personas que sin realizar acciones ejecutivas, deciden la realización de un delito en el ámbito de la delincuencia económica empresarial?, cit., p. 83.

${ }^{221}$ Como destaca Cezar Roberto Bitencourt, a condição pessoal do agente pode ser de natureza jurídica (acionista), profissional ou social (comerciante), natural (gestante, mãe), parentesco (descendente). BITENCOURT, Cezar Roberto. Tratado de direito penal: parte geral, cit., v. 1, p. 275.

${ }^{222}$ SILVA SÁNCHEZ, Jesús María. Responsabilidad penal de las empresas y de sus órganos en derecho español. Responsabilidade penal da pessoa jurídica: em defesa do princípio da imputação penal subjetiva, cit., p. 82.

${ }^{223}$ TOLEDO, Francisco de Assis. Princípios básicos de direito penal, cit., p. 141-142.

${ }^{224}$ Art. 327: Considera-se funcionário público, para os efeitos penais, quem, embora transitoriamente ou sem remuneração, exerce cargo, emprego ou função pública. $\S 1^{\circ}$ - Equipara-se a funcionário público quem exerce cargo, emprego ou função em entidade paraestatal, e quem trabalha para empresa prestadora de serviço contratada ou conveniada para a execução de atividade típica da Administração Pública. § $2^{\circ}$ - A pena será aumentada da terça parte quando os autores dos crimes previstos neste Capítulo forem ocupantes de cargos em comissão ou de função de direção ou assessoramento de órgão da administração direta, sociedade de economia mista, empresa pública ou fundação instituída pelo poder público.

${ }^{225}$ PAGLIARO, Antonio; COSTA JR., Paulo José da. Dos crimes contra a administração pública. 2. ed. São Paulo: Malheiros Ed., 1999. p. 30.
} 
Os crimes especiais representam, pois, uma modalidade dos chamados delitos de dever, ou delitos de violação de dever, nos quais a punibilidade do agente fica condicionada à violação de um dever especial. Nos casos dos delitos de dever, o que se afigura imprescindível para a configuração da autoria é a vinculação ao dever, e não a forma da contribuição concreta, se omissiva ou comissiva, de maior ou de menor importância ${ }^{226}$. Essa situação, como revela Claus Roxin, não tem nada a ver com domínio do fato, de resto inaplicável aos delitos de dever $^{227}$, mas com a descrição legal da imposição de um dever específico contida no tipo penal cuja infração fundamenta a autoria $^{228}$. Esse dever, que para Roxin tem natureza extrapenal ${ }^{229}$, pode não se estender a todos os responsáveis pelo delito, ou seja, quem concorrer para a realização do crime sem estar legalmente incumbido pelo tipo penal se transformará em partícipe da conduta ${ }^{230}$.

No Direito Penal Econômico consubstancia expediente relativamente comum a criação, pelo legislador, de crimes especiais que indicam a violação de deveres por parte dos administradores das organizações empresariais ou o domínio e a proximidade ao bem jurídico tutelado ${ }^{231}$. Nesse sentido, é possível mencionar, a título de exemplo, alguns crimes contra o sistema financeiro brasileiro, como o de gestão fraudulenta e temerária de instituição financeira ${ }^{232}$, o crime de apropriação de valores no âmbito de instituição financeira ${ }^{233}$, o de fazer operar, sem autorização ou com autorização obtida

\footnotetext{
${ }^{226}$ GRECO, Luís; LEITE, Alaor. O que é e o que não é a teoria do domínio do fato sobre a distinção entre autor e partícipe no Direito Penal, cit., p. 66.

${ }^{227}$ Id. Ibid., p. 65-66. Em sentido diverso, Francisco Muñoz Conde preconiza a possibilidade de incidência do domínio funcional do fato, em que se afasta a necessidade de execução conjunta da figura típica e se considera a ideia de realização conjunta, cujo principal fundamento repousa no controle ou no domínio que um ou vários sujeitos detenham sobre a execução do crime (MUÑOZ CONDE, Francisco. Problemas de autoría y participación en el derecho penal económico, o ¿cómo imputar a título de autores a las personas que sin realizar acciones ejecutivas, deciden la realización de un delito en el ámbito de la delincuencia económica empresarial?, cit., p. 94).

${ }^{228}$ ROXIN, Claus. Autoría y dominio del hecho en derecho penal, cit., p. 386.

${ }^{229}$ Id. Ibid., p. 387.

${ }^{230}$ Id. Ibid., p. 386.

${ }^{231}$ MUÑOZ CONDE, Francisco. Problemas de autoría y participación en el derecho penal económico, o ¿cómo imputar a título de autores a las personas que sin realizar acciones ejecutivas, deciden la realización de un delito en el ámbito de la delincuencia económica empresarial?, cit., p. 83.

${ }^{232}$ Art. $4^{\circ}$ Gerir fraudulentamente instituição financeira: Pena - Reclusão, de 3 (três) a 12 (doze) anos, e multa. Parágrafo único. Se a gestão é temerária: Pena - Reclusão, de 2 (dois) a 8 (oito) anos, e multa.

${ }^{233}$ Art. $5^{\circ}$ Apropriar-se, quaisquer das pessoas mencionadas no art. 25 desta lei, de dinheiro, título, valor ou qualquer outro bem móvel de que tem a posse, ou desviá-lo em proveito próprio ou alheio: Pena - Reclusão, de 2 (dois) a 6 (seis) anos, e multa. Parágrafo único. Incorre na mesma pena qualquer das pessoas mencionadas no art. 25 desta lei, que negociar direito, título ou qualquer outro bem móvel ou imóvel de que tem a posse, sem autorização de quem de direito.
} 
mediante declaração falsa, instituição financeira ${ }^{234}$, e o crime de empréstimo vedado ${ }^{235}$, os quais somente podem ser praticados pelos sujeitos que se enquadram no artigo 25 da Lei n. ${ }^{0} 7.492 / 1986^{236}$, ou seja, que apresentam funções de comando da instituição financeira.

A análise dos aportes pessoais na seara dos crimes especiais estampados na Lei n. ${ }^{\circ}$ 7.492/1986 emerge, por sinal, especialmente relevante no campo prático, haja vista a posição da jurisprudência brasileira no sentido de que esses delitos admitiriam tanto coautoria - inclusive por aquele que não detém a condição jurídica do artigo 25 da Lei n. ${ }^{\circ}$ $7.492 / 1986$ - como participação ${ }^{237}$. Essa postura da jurisprudência destoa, todavia, da

\footnotetext{
${ }^{234}$ Art. 16. Fazer operar, sem a devida autorização, ou com autorização obtida mediante declaração falsa, instituição financeira, inclusive de distribuição de valores mobiliários ou de câmbio: Pena - Reclusão, de 1 (um) a 4 (quatro) anos, e multa.

${ }^{235}$ Art. 17. Tomar ou receber, qualquer das pessoas mencionadas no art. 25 desta lei, direta ou indiretamente, empréstimo ou adiantamento, ou deferi-lo a controlador, a administrador, a membro de conselho estatutário, aos respectivos cônjuges, aos ascendentes ou descendentes, a parentes na linha colateral até o $2^{\circ}$ grau, consanguíneos ou afins, ou a sociedade cujo controle seja por ela exercido, direta ou indiretamente, ou por qualquer dessas pessoas: Pena - Reclusão, de 2 (dois) a 6 (seis) anos, e multa. Parágrafo único. Incorre na mesma pena quem: I - em nome próprio, como controlador ou na condição de administrador da sociedade, conceder ou receber adiantamento de honorários, remuneração, salário ou qualquer outro pagamento, nas condições referidas neste artigo; II - de forma disfarçada, promover a distribuição ou receber lucros de instituição financeira.

${ }^{236}$ Art. 25. São penalmente responsáveis, nos termos desta lei, o controlador e os administradores de instituição financeira, assim considerados os diretores, gerentes. $§ 1^{\circ}$ Equiparam-se aos administradores de instituição financeira o interventor, o liquidante ou o síndico. $\S 2^{\circ}$ Nos crimes previstos nesta Lei, cometidos em quadrilha ou co-autoria, o co-autor ou partícipe que através de confissão espontânea revelar à autoridade policial ou judicial toda a trama delituosa terá a sua pena reduzida de um a dois terços. Esse preceito legal da Lei $\mathrm{n}^{\circ} 7.492 / 1986$ não pode ser entendido como uma ferramenta para a formulação da imputação penal no contexto dos crimes contra o sistema financeiro nacional, interpretação que poderia gerar situações de atribuição de responsabilidade penal objetiva, mas apenas como um critério de exigência da qualidade jurídica do sujeito ativo de alguns crimes da Lei n. ${ }^{\circ}$ 7.492/1986.

${ }^{237}$ PENAL - CRIME CONTRA O SISTEMA FINANCEIRO NACIONAL - ART. $4^{\circ}$ DA LEI N ${ }^{\circ} 7.492 / 86$ GESTÃO FRAUDULENTA - OPERAÇÕES IRREGULARES DE EMPRÉSTIMOS NO BANCO DO BRASIL DESTINADOS AO MUNICÍPIO DE ANAURILÂNDIA/MS - MATERIALIDADE DELITIVA COMPROVAÇÃO - INDÍCIOS DE AUTORIA - CRIME PRÓPRIO - CO-AUTORIAE PARTICIPAÇÃO ADMISSIBILIDADE - RECEBIMENTO DA DENÚNCIA - PROVIMENTO DO RECURSO. 1. A materialidade do ilícito restou demonstrada de forma inequívoca pela confissão dos denunciados e pelos depoimentos das interpostas pessoas que emprestaram suas contas correntes, sendo que as mesmas informaram que foram aliciadas para realizar a operação fraudulenta. 2 . O crime próprio não apresenta incompatibilidade com a participação de pessoa despida da condição especial prevista no tipo. 3.- Tratandose de crime próprio, admite-se a participação e a co-autoria,em face do que dispõe o art. 30 do $\mathrm{CP}$, no sentido de que as elementares de caráter pessoal se comunicam entre os agentes. Desse modo, o paciente se equipara àquele que preenche os requisitos previstos na lei para figurar como sujeito ativo do crime. 4.Admissível, no crime próprio, o concurso de agentes (art. 29 do CP), inclusive quanto ao estranho à instituição financeira (art. 30 do $\mathrm{CP}$ ). 5.- Presentes os requisitos para o recebimento da denúncia. Provimento do recurso (Tribunal Regional Federal da $3^{a}$ Região, Embargos Infringentes e de Nulidade n. ${ }^{\circ}$ 3607, Rel.: Juiz Convocado Luciano Godoy, j. em 17.01.2006).

Também a seguinte Ementa de acórdão proveniente do Tribunal Regional Federal da $1^{\text {a }}$ Região no julgamento do habeas corpus n. ${ }^{\circ}$ 2008.01.000367300: PROCESSO PENAL. HABEAS CORPUS. CRIME CONTRA O SISTEMA FINANCEIRONACIONAL. ART. 17 DA LEI 7.492/86, C/C ART. 71 E 29 DO CP.
} 
construção doutrinária erguida por Claus Roxin, como a essa altura parece ser até mesmo intuitivo, pois o domínio do fato, como assentado, não aqui tem hipótese de incidência.

A solução para estabelecer corretamente a existência de coautoria nos delitos de dever passa pelo afastamento do critério do domínio do fato e a subsequente verificação da condição do cooperador como alguém que, concretamente, quebrou, ou não, em conjunto com outras pessoas, o dever extrapenal delineado no tipo penal ${ }^{238}$. Dessa circunstância deriva a natural redução do alcance da coautoria nessa modalidade delitiva, uma vez que o caráter comum que cerca a coautoria aparecerá tão-somente quando várias pessoas se encontrarem submetidas a um mesmo e único dever extrapenal ${ }^{239}$.

Daí a conclusão: a extensão subjetiva prevista no artigo 30 do Código Penal não torna aqueles que concorrem para o crime próprio contra o sistema financeiro nacional, mas que não se inserem no artigo 25 da Lei n. ${ }^{\circ}$ 7.492/1986, coautores, à vista da ausência de violação de um dever específico. Neste caso dar-se-á exclusivamente uma participação.

Para ilustrar essa asserção, pensemos no caso do crime de empréstimo vedado, tipificado no artigo 17 da Lei n. ${ }^{\circ}$ 7.492/1986, em que os cinco membros do Conselho de Administração de uma instituição financeira decidem, por votação unânime, deferir vultoso empréstimo a uma pessoa jurídica administrada pela esposa do conselheiro " $\underline{X}$ ", de nome " $\underline{A}$ ", mediante a emissão de cédulas de crédito bancário (CCB). A concessão desses recursos foi realizada a pedido de " $\underline{A}$ " e contou com a intervenção de " $\underline{C}$ ", gerente da agência bancária que elaborou diretamente a CCB sabendo que ela traduzia um empréstimo vedado. Adotando-se o posicionamento da jurisprudência brasileira, ter-se-ia

CRIME DO ART. 298 DO CP. DENÚNCIA INEPTA. INOCORRÊNCIA. QUEBRA DE SIGILO BANCÁRIO. PRODUZIDO PELO BANCO CENTRAL. PROVA ILÍCITA. INEXISTÊNCIA. 1. A denúncia não é inepta quando atende ao comando do art. 41 do CPP e descreve suficientemente a conduta do ora paciente, de modo a conformá-la nos delitos descritos no art. 17 da Lei $n^{\circ} 7.492 / 86$, na forma do art. 71 do Código Penal, em concurso de pessoas (art. 29 do Código Penal), assim como no art. 298 também do Código Penal, possibilitando o exercício pleno de sua defesa. 2. O fato de o paciente não pertencer ao Conselho de Administração do Banco Mercantil à época dos fatos, não ilide, de plano, a persecução criminal, tendo em vista que nada impede de serem processados outros agentes que com aqueles mencionados no art. 25 da Lei 7.492/86 pratiquem as condutas descritas no art. 17 da mesma lei, em coautoria ou participação, de acordo com os arts. 29 e 30 do CP. Precedente. 3. Não há que se falar em provas obtidas ilicitamente mediante a quebra de sigilo bancário, quando estas provas são obtidas pelo Banco Central do Brasil no cumprimento do seu dever institucional de fiscalização das operações do Sistema Financeiro. Precedentes. 4. Habeas corpus denegado.

${ }^{238}$ ROXIN, Claus. Autoría y dominio del hecho en derecho penal, cit., p. 389.

${ }^{239}$ Id. Ibid., p. 391. 
uma hipótese de coautoria entre os cincos membros dos Conselhos de Administração e o gerente " $\underline{C}$ ", uma vez que ele executou parte do tipo penal elaborando a CCB. Além disso, ainda que se considere que o gerente de uma específica agência bancária não se enquadraria no artigo 25 da Lei n. ${ }^{\circ}$ 7.492/1986, ele seria alcançado pela regra de extensão do artigo 30 do Código Penal brasileiro. Entretanto, " $\underline{C}$ " não violou o mesmo dever dos cinco conselheiros coautores que exercem o comando da instituição financeira e que detêm o dever extrapenal de manter a higidez da instituição financeira, não podendo ser considerado, em consequência, coautor, mas cúmplice, pelo auxílio material, na linha do que defende Claus Roxin em relação aos delitos especiais. "므", a nosso ver, é instigadora em ambas as hipóteses por ter lançado a ideia criminosa no órgão colegiado, merecendo reprimenda mais acentuada na forma do artigo 29, caput, do Estatuto Penal brasileiro.

Nas votações em órgãos colegiados que redundam em fatos criminosos, como no exemplo supramencionado, todos os componentes que intervieram mediante a emissão dolosa de voto favorável serão imputados na condição de coautores, pois infringiram o dever constante no tipo penal. De ver-se que, aqui, não se cogita de responsabilização penal por fato próprio de cada membro do Conselho de Administração, mas de um fato atribuível a todo o órgão colegiado, sendo irrelevante se a votação se desenvolveu de modo simultâneo ou sucessivo ${ }^{240}$. Em igual medida, se algum membro do órgão de administração superior da sociedade manifestar-se contrariamente à resolução submetida à análise do colegiado, afastar-se-á a incidência de responsabilidade penal, o mesmo ocorrendo na hipótese do membro que estava ausente quando da deliberação ${ }^{241}$.

Sob outro giro, não se pode deixar de referir que a distinção entre a intervenção no fato criminoso por intermédio da autoria ou em razão da participação nos delitos especiais tem a sua ratio essendi em alguns ordenamentos jurídicos que, para algumas específicas situações, cominam penas equivalentes às dos autores para os partícipes. No Direito Penal espanhol, por exemplo, a cumplicidade prevista no artigo $29^{242}$

\footnotetext{
${ }^{240}$ GARCÍA CAVERO, Percy. Derecho penal económico: parte general, cit., t. 1, p. 715.

${ }^{241}$ Id. Ibid., p. 715-716.

${ }^{242}$ Artículo 29. Son cómplices los que, no hallándose comprendidos en el artículo anterior, cooperan a la ejecución del hecho con actos anteriores o simultáneos.
} 
se distancia da cooperação necessária, delineada no artigo 28 , alínea $b^{243}$, porque a pena do cooperador necessário, conquanto sua conduta seja considerada secundária, será a mesma reprimenda do autor, enquanto a pena do cúmplice será concretizada em patamar condizente com a natureza acessória da intervenção ${ }^{244}$. Essa equiparação punitiva tem sido objeto de crítica, como recorda Francisco Muñoz Conde, pois não parece materialmente justo que o agente que não esteja vinculado a um dever específico receba a mesma pena daquele que o tenha, embora seja considerado um cooperador necessário pela lei espanhola ${ }^{245}$. Essa situação é ajustada pela jurisprudência através de um "remendo" interpretativo eivado de insegurança jurídica, o qual parte da consideração de que, a despeito da realização da contribuição necessária, a conduta do cooperador será apenada de forma atenuada, ou seja, como se, em verdade, se tratasse de um caso de cumplicidade ${ }^{246}$.

O mesmo raciocínio pode ser aplicado ao Direito Penal brasileiro, por se adotar, ao menos pela dicção do artigo 29 do Código Penal, um conceito unitário e extensivo de autor. Com efeito, embora o dispositivo legal brasileiro deixe nas mãos do juiz a graduação da pena em virtude da apreciação da medida da culpabilidade, o que, aliás, soa algo extremamente genérico, senão etéreo, não nos parece razoável punir, do mesmo modo, aqueles que possuem deveres especiais e aqueles que, embora tenham concorrido materialmente para o delito próprio, não os possuem. Vale dizer: o critério alvitrado para os delitos especiais, além das questões de imputação penal anteriormente relatadas, também se afigura relevante para a realização da punição do caso concreto.

\footnotetext{
${ }^{243}$ Artículo 28. Son autores quienes realizan el hecho por sí solos, conjuntamente o por medio de otro del que se sirven como instrumento. También serán considerados autores: a) Los que inducen directamente a otro u otros a ejecutarlo. b) Los que cooperan a su ejecución con un acto sin el cual no se habría efectuado.

${ }^{244}$ Francisco Muñoz Conde também é adepto da coautoria (MUÑOZ CONDE, Francisco. Problemas de autoría y participación en el derecho penal económico, o ¿cómo imputar a título de autores a las personas que sin realizar acciones ejecutivas, deciden la realización de un delito en el ámbito de la delincuencia económica empresarial?, cit., p. 89).

${ }^{245}$ Id. Ibid., p. 91.

${ }^{246}$ Id. Ibid., p. 92.
} 


\subsection{Imputação penal em razão de condutas omissivas}

Constitui tendência moderna a proposta de formulação da imputação penal de crimes praticados no ambiente da organização empresarial por intermédio de critérios relacionados à violação de garante e, portanto, mediante o instituto da omissão. Percy Garcia Cavero esclarece, sobre essa tendência, que a atribuição de responsabilidade penal às pessoas físicas por condutas omissivas tem sido empreendida, no plano doutrinário, por duas vias distintas, ambas destinadas a evitar as lacunas de punibilidade decorrentes da ausência da responsabilidade penal da pessoa jurídica: a primeira, recorrendo-se à figura dos crimes omissivos impróprios ou comissivos por omissão; a segunda, propondo-se a criação de um dever de vigilância dos dirigentes da sociedade face às condutas cometidas a partir da sociedade empresária ${ }^{247}$.

Sob esse contexto, é relevante advertir que a análise a ser desenvolvida não se pretende exauriente ou mesmo abrangente, centrando foco nos modelos de imputação penal lastreados exclusivamente nos crimes omissivos impróprios e na correspondente verificação da potencial posição de garante do administrador da sociedade.

Dessa forma, não abordaremos todos os aspectos conceituais da omissão penalmente relevante ou mesmo as nuances dos crimes omissivos próprios, mas apenas investigaremos os elementos conceituais que podem ensejar a imputação penal dos atos cometidos no âmbito das organizações empresariais que escapam dos modelos comissivos anteriormente analisados.

\subsubsection{Crimes comissivos por omissão ou omissivos impróprios}

A essência da tipicidade dos crimes omissivos impróprios ou comissivos por omissão reside na violação de um dever de agir ou dever de garante incidente sobre determinada pessoa que, no caso concreto, poderia agir para evitar o resultado criminoso.

${ }^{247}$ GARCÍA CAVERO, Percy. Derecho penal económico: parte general, cit., t. 1, p. 695. 
Ao contrário do que sucede com os crimes omissivos puros, nos crimes comissivos por omissão a conduta incriminada não vem descrita no tipo penal, devendo-se, pois, recorrer a uma cláusula geral prevista na legislação penal para a formulação da imputação penal ${ }^{248}$.

No plano da criminalidade de empresa, a estrutura dos crimes comissivos por omissão têm servido para justificar a punição, por omissão imprópria, ou seja, por quebra do dever de garante, dos membros dos órgãos de administração da pessoa jurídica que não evitaram, embora pudessem, o cometimento do delito pelos subordinados ${ }^{249}$.

Nesse sentido, em ordem a possibilitar a responsabilidade penal dos componentes do órgão diretivo pela via da omissão, exsurge fundamental a existência, para o administrador da sociedade empresária, do dever jurídico de impedir o resultado levado a efeito pelo empregado no curso da atividade de empresa desenvolvida pela sociedade. E, sob esse contexto, para além das fontes formais do dever de garante, que emergem de disposições legais expressas, existiriam fontes materiais hábeis a sustentar a posição de garante e, portanto, a penalização pela conduta omissiva imprópria, baseadas no dever de proteger determinados bens jurídicos ou velar por determinadas fontes de perigo ${ }^{250}$.

Schünemann tem abordado essa questão sob a perspectiva do domínio sobre o fundamento do resultado ${ }^{251}$. Segundo ele, o fundamento da equivalência entre a ação e a omissão não radica na mera violação de um dever de caráter extrapenal ou de um perigo causal que emana do comportamento anterior do autor, mas no controle que indivíduo ostenta sobre o processo causal que se desenvolve até a lesão ao bem jurídico ou, ainda, que deriva como consequência da vigilância da fonte de perigo ou do domínio incidente sobre a proteção do bem jurídico ${ }^{252}$. No plano empresarial, a ideia de domínio sobre o fundamento do resultado tem a aptidão de fundamentar, para Schünemann, o dever de

\footnotetext{
${ }^{248}$ PASCHOAL, Janaina Conceição. Ingerência indevida: os crimes comissivo por omissão e o controle pela punição do não fazer. Porto Alegre: Sergio Antonio Fabris, 2011. p. 36.

${ }^{249}$ MARTÍNEZ-BUJÁN PÉREZ, Carlos. Derecho penal económico y de la empresa: parte general, cit., p. 498-499.

${ }^{250}$ GARCÍA CAVERO, Percy. Derecho penal económico: parte general, cit., t. 1, p. 696. Como explica Juarez Cirino dos Santos, o critério formal tem em seu favor a segurança jurídica, mas a rigidez de sua conformação fundamenta seu desprestígio pela doutrina penal mais moderna (SANTOS, Juarez Cirino dos. Direito penal: parte geral, cit., p. 202).

${ }^{251}$ SCHÜNEMANN, Bernd. Sobre la regulación de los delitos de omisión impropia en los eurodelitos. TIEDEMANN, Klaus (Dir.); NIETO MARTÍN, Adán (Coord.). Eurodelitos: el derecho penal económico en la Unión Europea. Cuenca: Ediciones de la Universidad de Castilla-La Mancha, 2004. p. 37.

${ }^{252}$ Id. Ibid., p. 37.
} 
garantia do "chefe da empresa" por comportamentos defeituosos dos órgãos subordinados para aqueles casos em que a atividade criminosa ocorre em benefício da sociedade empresária e tenha sido resultado da obediência de uma ordem expressa. Essa circunstância faz com que os comportamentos dos empregados que excederem essas duas condições não possam ser imputados penalmente aos membros dos órgãos de direção, excetuados os casos nos quais existe domínio efetivo e concreto sobre a fonte de perigo ${ }^{253}$.

Sob esse contexto, existiriam duas modalidades de domínio que recairiam sobre os administradores da organização empresarial: o domínio material, relativo ao controle fático sobre os procedimentos perigosos adotados pela sociedade empresária, e o domínio pessoal, pertinente ao comportamento dos subordinados. A primeira forma de domínio e a correspondente posição de garante somente tem cabimento em relação ao âmbito específico de competência do órgão de comando, de modo que, em estruturas empresariais complexas, não existe dever de garante para fatos que refogem da esfera de atribuição do órgão diretivo. No domínio pessoal, a responsabilidade omissiva do administrador deriva do poder de mando por ele exercido, de resto inerente à estrutura hierárquica da pessoa jurídica, bem como da maior quantidade de informações que ele possui, ao contrário do que sucede com o subordinado, cuja informação é fragmentada ${ }^{254}$.

O tema da responsabilidade penal do órgão diretivo por omissão se torna mais complexo, porém, nos casos de delegação do poder de controle da sociedade empresária a pessoas que não não figuram como titulares da organização empresarial. É o caso, por exemplo, das Sociedades Anônimas, em que o poder de controle não é, em regra, exercido pelos acionistas, mas por órgãos colegiados eleitos (Conselho de Administração e Diretoria) através dos votos emitidos na Assembleia-geral e pelo próprio Conselho ${ }^{255}$. Para essas hipóteses, tem-se proposto a transferência, para os delegados, dos deveres de vigilância e controle sobre os riscos que emanam do exercício da atividade empresarial ${ }^{256}$.

\footnotetext{
${ }^{253}$ SCHÜNEMANN, Bernd. Sobre la regulación de los delitos de omisión impropia en los eurodelitos, cit., p. 37. ${ }^{254}$ MARTÍNEZ-BUJÁN PÉREZ, Carlos. Derecho penal económico y de la empresa: parte general, cit., p. 501.

${ }^{255}$ Artigo 140 da Lei n. ${ }^{\circ}$ 6.404/1976: O conselho de administração será composto por, no mínimo, 3 (três) membros, eleitos pela assembléia-geral e por ela destituíveis a qualquer tempo, devendo o estatuto estabelecer (...). Artigo 143 da Lei n. ${ }^{\circ}$ 6.404/1976: A Diretoria será composta por 2 (dois) ou mais diretores, eleitos e destituíveis a qualquer tempo pelo conselho de administração, ou, se inexistente, pela assembléia-geral, devendo o estatuto estabelecer (...).

${ }^{256}$ GARCÍA CAVERO, Percy. Derecho penal económico: parte general, cit., t. 1, p. 700.
} 
Aos delegantes, a sua vez, subsistiriam alguns deveres de seleção, informação, controle e vigilância, que, conquanto não sejam suficientes para embasar a responsabilidade penal por omissão propriamente dita, como aponta Garcia Cavero, ensejariam situações de participação omissiva $^{257}$. O projeto de eurodelitos para a Comunidade Europeia, contudo, parece ter adotado posição diversa na redação do artigo 15.4., talvez em razão da influência exercida pelos seus dois autores, Klaus Tiedemann e Bernd Schünemann, ao estabelecer expressamente que a delegação da responsabilidade somente isenta de responsabilidade penal se se referir a um determinado segmento da atividade e existir certeza de que o delegado pode realizar eficazmente as tarefas e atribuições que lhe foram transferidas e que essa situação não tem a aptidão de modificar nem a responsabilidade por eleição, vigilância e controle, e nem a responsabilidade geral derivada da organização.

No Direito Penal brasileiro a cláusula geral de onde deriva do dever de garante nos crimes comissivos por omissão encontra-se prevista no artigo $13, \S 2^{\circ}$, do Código Penal. Assim, pelo ordenamento jurídico brasileiro será garantidor aquele que, (i) em função de um mandamento legal específico, tem a obrigação de cuidado, proteção ou vigilância; (ii) que, de outra forma, tornou-se garantidor da inocorrência do resultado; e aquele que (iii) com seu comportamento anterior, criou o risco da ocorrência do resultado.

O rol que enuncia os deveres de garante, além da óbvia vantagem de conferir segurança jurídica e atender às exigências do princípio constitucional da reserva legal, transforma o crime comissivo por omissão em próprio, na medida em que somente aquele indivíduo que se encontra inserido na lista do artigo 13 poderá cometer a infração penal. Ademais, ele também interfere na tipicidade penal, como recorda Janaina Paschoal, "pois só haverá um crime comissivo por omissão se houver um omitente garantidor"258.

A resolução dos problemas relacionados à imputação penal pelo cometimento de condutas omissivas impróprias no contexto das organizações empresariais passa, portanto, pelo menos do ponto de vista das fontes formais, pela análise das hipóteses

\footnotetext{
${ }^{257}$ GARCÍA CAVERO, Percy. Derecho penal económico: parte general, cit., t. 1, p. 700. Em sentido contrário, sustentando a existência de autoria ao delegante que infringe dolosa ou culposamente o seu dever de intervenção ou seu dever de vigilância: MARTÍNEZ-BUJÁN PÉREZ, Carlos. Derecho penal económico $y$ de la empresa: parte general, cit., p. 510.

${ }^{258}$ PASCHOAL, Janaina Conceição. Ingerência indevida: os crimes comissivo por omissão e o controle pela punição do não fazer, cit., p. 44.
} 
legais de imposição do dever de garante. Sob esse panorama, em relação à posição de garante derivada de um mandamento legal específico, poder-se-ia argumentar que diversos diplomas legais que impõem aos membros dos órgãos diretivos das sociedades empresárias deveres de cuidado, proteção ou vigilância, como demonstrado particularmente no Capítulo II. Deveras, no que tange às sociedades anônimas, relembre-se, a Lei n. ${ }^{\circ}$ 6.404/1976 impõe aos administradores diversos deveres atinentes à diligência ${ }^{259}$, à lealdade $^{260}$ e à informação plena ${ }^{261}$, visando a concretização dos interesses da companhia, desde que satisfeitas as exigências do bem público e da função social da empresa ${ }^{262}$. O mesmo sucede com as sociedades empresárias regidas pelo Código Civil brasileiro ${ }^{263}$. Essas situações derivariam, contudo, exclusivamente de fatos que guardam pertinência temática com o objeto social da sociedade, com o desempenho da atividade de empresa.

Não obstante, esses deveres carecem da concretude necessária à fundamentação da posição de garante, ou seja, exsurgem demasiadamente genéricos e, além disso, encontram-se proximamente atrelados aos interesses econômicos da própria sociedade empresária, sem que se extraia daí, em consequência, mandado específico ${ }^{264}$.

Outra via possível reside na consideração da posição de garantidor em virtude da ingerência, isto é, de modo que o dever de salvamento do bem jurídico incidiria quando o comportamento anterior criar o risco da ocorrência do resultado (art. 13, $\S 2^{\circ}, c$, do CP). Essa postura tem sido acolhida majoritariamente pela doutrina mas, como lembra Eduardo Demetrio Crespo, a imputação penal para esse caso não pode basear-se exclusivamente na mera relação de causalidade, senão na criação de um risco desaprovado

\footnotetext{
${ }^{259}$ Art. 153. O administrador da companhia deve empregar, no exercício de suas funções, o cuidado e diligência que todo homem ativo e probo costuma empregar na administração dos seus próprios negócios.

${ }^{260}$ Art. 155. O administrador deve servir com lealdade à companhia e manter reserva sobre os seus negócios, sendo-lhe vedado: I - usar, em benefício próprio ou de outrem, com ou sem prejuízo para a companhia, as oportunidades comerciais de que tenha conhecimento em razão do exercício de seu cargo; II - omitir-se no exercício ou proteção de direitos da companhia ou, visando à obtenção de vantagens, para si ou para outrem, deixar de aproveitar oportunidades de negócio de interesse da companhia; III - adquirir, para revender com lucro, bem ou direito que sabe necessário à companhia, ou que esta tencione adquirir.

${ }^{261}$ Art. 157. O administrador de companhia aberta deve declarar, ao firmar o termo de posse, o número de ações, bônus de subscrição, opções de compra de ações e debêntures conversíveis em ações, de emissão da companhia e de sociedades controladas ou do mesmo grupo, de que seja titular.

${ }^{262}$ Art. 154. O administrador deve exercer as atribuições que a lei e o estatuto lhe conferem para lograr os fins e no interesse da companhia, satisfeitas as exigências do bem público e da função social da empresa.

${ }^{263}$ Art. 1.011. O administrador da sociedade deverá ter, no exercício de suas funções, o cuidado e a diligência que todo homem ativo e probo costuma empregar na administração de seus próprios negócios.

${ }^{264}$ CRESPO, Eduardo Demetrio. Responsabilidad penal por omisión del empresario. Madrid: Iustel, 2009. p. 126.
} 
ao bem jurídico ${ }^{265}$. Concretamente: o mero funcionamento regular da sociedade empresária não traduz, por si só, uma situação de perigo hábil a conduzir à imputação penal objetiva.

Com efeito, não ignora que algumas atividades empresariais são inerentemente perigosas, comportando, com isso, ampla regulamentação de natureza extrapenal. Esse fator será relevante na elaboração da atribuição de responsabilidade penal ao órgão de direção, na medida em que a imputação objetiva do resultado somente pode ser delineada quando houver violação dessas normas de regulamentação (risco desaprovado).

\subsubsection{A infração do dever de vigilância na sociedade empresária}

Em ordem a evitar lacunas de punibilidade no âmbito do Direito Penal Econômico, a doutrina tem preconizado, de lege ferenda, a necessidade de um tipo penal contendo uma omissão própria que alcance situações não abrangidas pelo dever de garante e que, em consequência, promova a responsabilização do agente em virtude da infração dolosa ou culposa de um dever de vigilância de evitar a realização de crimes no contexto da organização ${ }^{266}$.

Neste caso, dispensar-se-ia a necessidade de demonstração do vínculo existente entre o membro do órgão de direção da sociedade empresária e o fato criminoso, bastando, para a realização da incriminação, a demonstração de um defeito organizativo nas medidas de vigilância. O problema, como destaca Percy Garcia Cavero, radica na desnecessidade de algum delito vir a ser efetivamente perpetrado, ostentando, assim, um injusto autônomo ${ }^{267}$.

\footnotetext{
${ }^{265}$ CRESPO, Eduardo Demetrio. Responsabilidad penal por omisión del empresario, cit., p. 127.

${ }^{266}$ GARCÍA CAVERO, Percy. Derecho penal económico: parte general, cit., t. 1, p. 701.

${ }^{267}$ Id. Ibid., p. 702-703.
} 


\section{CRIMINALIDADE EMPRESARIAL E ORGANIZAÇÕES CRIMINOSAS}

\subsection{Introdução: globalização, organização e crime}

A prática de crimes por intermédio de uma coletividade não constitui novidade no Brasil ${ }^{268}$. De fato, a tipificação penal da agremiação de agentes com o escopo de perpetrar infrações penais consubstancia expediente relativamente comum - e às vezes criticável - no ordenamento jurídico pátrio, como se percebe da redação do crime de quadrilha ou bando $^{269}$, recentemente rebatizado, aliás, de associação criminosa ${ }^{270}$.

Não obstante a tradicional presença dessas modalidades delitivas, detectamos uma clara tendência ampliativa visando à incriminação de condutas levadas a efeito em contextos coletivos. No âmbito brasileiro, ilustram essa tendência figuras como a

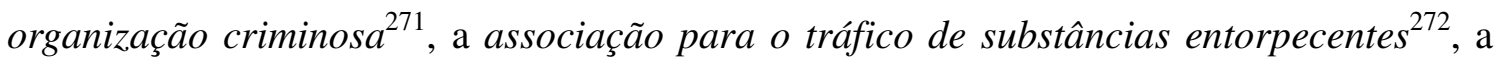

\footnotetext{
${ }^{268}$ Como registra Antônio Sérgio Altieri de Moraes Pitombo (Organização criminosa, nova perspectiva do tipo legal, cit., p. 64 e ss).

${ }^{269}$ Artigo 288 (redação antiga) do Código Penal: Associarem-se mais de três pessoas, em quadrilha ou bando, para o fim de cometer crimes. Pena: reclusão, de 1 (um) a 3 (três) anos. Parágrafo único: A pena aplica-se em dobro, se a quadrilha ou bando é armado.

${ }^{270}$ A redação do artigo 288 do Código Penal foi modificada pela Lei n. ${ }^{\circ} 12.850 / 2013$, passando a figurar nos seguintes termos: Associarem-se 3 (três) ou mais pessoas, para o fim específico de cometer crimes: Pena: reclusão, de 1 (um) a 3 (três) anos. Parágrafo único. A pena aumenta-se até a metade se a associação é armada ou se houver a participação de criança ou adolescente.

${ }^{271}$ Recentemente definida, em termos definitivos, no artigo $1^{\circ}, \S 1^{\circ}$, da Lei n. ${ }^{\circ} 12.850$, de 2 de agosto de 2013: Considera-se organização criminosa a associação de 4 (quatro) ou mais pessoas estruturalmente ordenada e caracterizada pela divisão de tarefas, ainda que informalmente, com objetivo de obter, direta ou indiretamente, vantagem de qualquer natureza, mediante a prática de infrações penais cujas penas máximas sejam superiores a 4 (quatro) anos, ou que sejam de caráter transnacional. O tipo penal está estampado no artigo $2^{\circ}$ : Promover, constituir, financiar ou integrar, pessoalmente ou por interposta pessoa, organização criminosa: Pena - reclusão, de 3 (três) a 8 (oito) anos, e multa, sem prejuízo das penas correspondentes às demais infrações penais praticadas. $\S 1^{-}$Nas mesmas penas incorre quem impede ou, de qualquer forma, embaraça a investigação de infração penal que envolva organização criminosa.

${ }^{272}$ Artigo 35 da Lei n. ${ }^{\circ}$ 11.343/2006: Associarem-se duas ou mais pessoas para o fim de praticar, reiteradamente ou não, qualquer dos crimes previstos nos arts. 33, caput e $\S 1^{\underline{o}}$, e 34 desta Lei: Pena reclusão, de 3 (três) a 10 (dez) anos, e pagamento de 700 (setecentos) a 1.200 (mil e duzentos) dias-multa. Parágrafo único. Nas mesmas penas do caput deste artigo incorre quem se associa para a prática reiterada do crime definido no art. 36 desta Lei.
} 
associação para o genocídio ${ }^{273}$, a milícia privada ${ }^{274}$ e a lavagem de dinheiro pratica por intermédio de grupo, associação ou escritório ${ }^{275}$. Essa postura derivaria, segundo Jesús María Silva Sánchez, da globalização, uma vez que a criminalidade globalizada apresentase, em sentido amplo, organizada, estruturalmente hierarquizada, quer por força da existência de organizações empresariais que acabam, em maior ou menor medida, tomando parte de atividades delituosas, quer em razão da presença das organizações criminosas ${ }^{276}$. Sintetiza Laura Zúñiga Rodríguez que a coletivização, a organização, a divisão de trabalho e as hierarquias consubstanciam elementos essenciais aos sistemas sociais modernos ${ }^{277}$.

Sob esse contexto, não nos parece possível analisar o contexto políticocriminal no qual se inserem os delitos de organização sem mencionar a globalização. Enquanto fenômeno complexo e multifacetado, a globalização trouxe enormes implicações nas mais diversas áreas do conhecimento, em especial no Direito ${ }^{278}$.

Vale dizer: com a globalização, o manancial jurídico disponível em cada país passou a lidar com uma sociedade excessivamente tecnológica, massificada e de informação, onde a conduta dos seres humanos, no mais das vezes marcada pelo anonimato, encontra-se apta a produzir riscos globais suscetíveis de "serem produzidos em tempo e em lugar largamente distanciados da acção que os originou ou para eles contribuiu e de poderem ter como consequência, pura e simplesmente, a extinção da vida",279.

\footnotetext{
${ }^{273}$ Artigo $2^{\circ}$ da Lei n. ${ }^{\circ}$ 2.889/1956: Associaram-se mais de 3 (três) pessoas para a prática dos crimes mencionados no artigo anterior. Pena: Metade da cominada aos crimes ali previstos.

${ }^{274}$ Prevista no artigo 288-A do Código Penal: "Constituir, organizar, integrar, manter ou custear organização paramilitar, milícia particular, grupo ou esquadrão com a finalidade de praticar qualquer dos crimes previstos neste Código: Pena - reclusão, de 4 (quatro) a 8 (oito) anos".

${ }^{275}$ Artigo $1^{\circ}, \S 2^{\circ}$, II, da Lei n. ${ }^{\circ} 9.613 / 1998$ : Incorre, ainda, na mesma pena quem: II - participa de grupo, associação ou escritório tendo conhecimento de que sua atividade principal ou secundária é dirigida à prática de crimes previstos nesta Lei.

${ }^{276}$ SILVA SÁNCHEZ, Jesús María. La expansión del derecho penal: aspectos de la política criminal en las sociedades postindustriales, cit., p. 90-91. Silva Sánchez aponta, em acréscimo, que do ponto de vista material a criminalidade da globalização relaciona-se à criminalidade de sujeitos poderosos, caracterizada pela magnitude de seus efeitos, em regra econômicos, mas que também atingem as esferas políticas e sociais (Id. Ibid., p. 91).

${ }^{277}$ ZÚÑIGA RODRÍGUEZ Laura. Bases para un modelo de imputación de responsabilidad penal a las personas jurídicas. 3. ed. Navarra: Editorial Aranzadi, 2009. p. 85.

${ }^{278}$ FARIA, José Eduardo. O direito na economia globalizada. 1. ed. 4. tir. São Paulo: Malheiros Ed., 2004. p. 7.

${ }^{279}$ DIAS, Jorge de Figueiredo. Direito penal: parte geral: questões fundamentais: a doutrina geral do crime, cit., t. 1, p. 134-135.
} 
No âmbito do Direito Penal, o fenômeno da globalização tornou-se mais visível na criminalidade econômica ${ }^{280}$, da qual derivou, especialmente por força da utilização constante do sistema financeiro nacional e internacional, a "lavagem" de dinheiro, o tráfico de substâncias entorpecentes, o tráfico de seres humanos etc. ${ }^{281}$.

A supressão das fronteiras acarretou uma maior capacidade de movimentação dos membros das organizações criminosas pelo mundo com um menor risco. Aliando a progressiva desregulamentação do mercado e dos serviços financeiros no espaço global a uma rede de comunicação extremamente eficiente, os agentes incrementaram sensivelmente sua gama de atividades deletérias ${ }^{282}$.

Some-se a isso a dificuldade de as condutas praticadas sob os influxos dessa "sociedade de risco" irradiarem aspectos externos de legalidade, de licitude, dificultando a atuação expedita das autoridades destinadas à persecução penal ${ }^{283}$.

A comunidade internacional percebeu, então, que um esforço isolado dos países seria inútil; que, por seus próprios instrumentos legais, não fariam frente a esse novo fenômeno e, assim, uniram-se no combate ao crime global, harmonizando seus

\footnotetext{
${ }^{280}$ SILVA SÁNCHEZ, Jesús María. La expansión del derecho penal: aspectos de la política criminal en las sociedades postindustriales, cit., p. 95.

${ }^{281}$ Como adverte José de Faria Costa, "Tentar perceber o fenómeno da criminalidade transnacional, não como um qualquer bizarro fenómeno social mas antes como uma decorrência da própria ideia de globalização. Perceber esse fenómeno, não como exaltação de uma visão conspirativa da história da sociedade, mas antes como actuação racional de homens que agindo, se bem que no campo do ilícito penal, pretendem, sobretudo, captar o maior benefício ilícito que as novas possibilidades de um mercado global lhes propicia" (COSTA, José de Faria. O fenómeno da globalização e o Direito Penal Económico. In: INSTITUTO DE DIREITO PENAL ECONÓMICO E EUROPEU. Direito penal económico e europeu: textos doutrinários. Coimbra: Coimbra Ed., 2009. v. 3, p. 102-103).

${ }^{282}$ DAVIN, João. A criminalidade organizada transnacional: a cooperação judiciária e policial na UE. 2. ed. rev. e aum. Coimbra: Almedina, 2007. p. 12. Como recorda o sociólogo Manuel Castells, nas "duas últimas décadas, as organizações criminosas vêm estabelecendo, cada vez mais, suas operações de uma forma transnacional, aproveitando-se da globalização econômicas das novas tecnologias de comunicações e transportes. A estratégia utilizada consiste em instalar suas funções de gerenciamento e produção em áreas de baixo risco, nas quais detêm relativo controle do meio institucional e voltar a atenção, como mercados preferenciais, às áreas com a demanda mais afluente, de modo que possam cobrar preços mais elevados" (CASTELLS, Manuel. A era da informação: economia, sociedade e cultura. 5. ed. São Paulo: Paz e Terra, 2009. v. 3, p. 205).

${ }^{283}$ Como pontua Anabela Miranda Rodrigues, o que define a sociedade atual é a "porosidade cada vez maior entre a sociedade oficial e a sociedade do crime" (RODRIGUES, Anabela Miranda. Criminalidade organizada: que política criminal? In: GLOBALIZAÇÃO e direito. Coimbra: Boletim da Faculdade de Direito da Universidade de Coimbra; Coimbra Ed., 2003. p. 198. (Studia Iuridica, n. 73).
} 
ordenamentos jurídicos e uniformizando as ferramentas de prevenção, repressão e cooperação $^{284}$.

Dessa comunhão de esforços surgiram, por exemplo, a Convenção de Viena, contra o tráfico ilícito de entorpecentes e de substâncias psicotrópicas ${ }^{285}$, a Convenção de Palermo, sobre a criminalidade organizada transnacional ${ }^{286}$, e a Convenção de Mérida, versando o crime de corrupção ${ }^{287}$, além de outras iniciativas de caráter supranacional, como a criação pelo grupo dos sete países mais ricos do mundo (G7), do Grupo de Atuação Financeira (GAFI) em 1989 e a emissão de Diretivas pelo Parlamento Europeu e Conselho da Comunidade Europeia ${ }^{288}$.

\subsection{O injusto nos delitos de organização}

A análise do injusto ${ }^{289}$ nos delitos de organização, ou seja, a valoração do comportamento como sendo antijurídico e culpável, vincula-se à sua própria legitimidade.

\footnotetext{
${ }^{284}$ JORGE, Guillermo. Recuperación de activos de la corrupción. 1. ed. Ciudad Autónoma de Buenos Aires: Del Puerto, 2008. p. 9-10. O efeito colateral dessa unificação e uniformização, segundo aponta Jesús-Maria Silva Sanchéz, proporcionará um Direito menos garantista, marcado pela flexibilização das regras de imputação penal e pela relativização das garantias político-criminais materiais e processuais. Essa expansão do Direito penal redundará, ao fim e ao cabo, na introdução de novos tipos penais, no agravamento das sanções cominadas aos delitos já existentes e na ampliação dos espaços de risco juridicamente relevantes (SILVA SÁNCHEZ, Jesús María. La expansión del derecho penal: aspectos de la política criminal en las sociedades postindustriales, cit., p. 83-84).

${ }^{285}$ Promulgada no Brasil por meio do Decreto n. ${ }^{\text {o }} 154$, de 26 de junho de 1991.

${ }^{286}$ Promulgada no Brasil pelo Decreto n. ${ }^{\circ}$ 5.015, de 12 de março de 2004.

${ }^{287}$ Promulgada, no ordenamento jurídico brasileiro, pelo Decreto 5.687, de 31 de janeiro de 2006.

${ }^{288}$ Para uma análise completa dos instrumentos internacionais relativos especificamente ao crime de ao branqueamento de capitais: BLANCO CORDERO, Isidoro. El delito de blanqueo de capitales. 2. ed. Navarra: Editorial Aranzadi, 2002. p. 98-171.

${ }^{289} \mathrm{O}$ injusto proporciona que valoremos a conduta do individuo. No Direito Penal divide-se o injusto em duas classes: (i) monistas e (ii) dualistas. Na primeira fala-se em monistas objetivas, quando o desvalor do resultado é o conteúdo do injusto (aquilo causado pelo autor ou o perigo que gerou), e monistas subjetivas, quando o desvalor recai sobre a ação (desvalor da intenção, aquilo que o agente quis ou a seu descuido); de outro lado, no grupo dualista, tem-se a corrente majoritária, que analisa o injusto a partir do desvalor tanto do ponto de vista da ação como do resultado, e os dualistas moderados, quando sustenta o desvalor da ação como fundamento do injusto, mas que nela não se esgota, servindo o desvalor do resultado como critério de gravidade do injusto (BURGUÑO DUARTE, Luz Berthila. Injusto colectivo con especial referencia a la responsabilidad penal por organización. México: Universidad Nacional Autónoma de México, 2009. p. 82-83).
} 
A partir do momento que o legislador incrimina condutas suscitadas em ambientes coletivos deve-se, em contrapartida, estabelecer a que interesse serve essa incriminação, ou o quê ela protege. Até porque, em regra, as penas aplicadas às pessoas que compõem a organização costumam ser severas e a cominação de sanção no mais das vezes independe da perpetração do crime que motivou a criação da organização.

A questão, todavia, não se afigura simples, notadamente se a abordagem ocorrer sob os auspícios de um Direito Penal que recusa a incriminação de atos de cogitação e a penalização de sujeitos pelo que são e não por aquilo que eles efetivamente fizeram, isto é, que abomina o Direito Penal do Autor e a atribuição de responsabilidade penal sem culpabilidade.

Demais disso, não se pode olvidar que a incriminação pela constituição de organizações delitivas, para além de gerar uma aparente fricção ao direito constitucional de livre associação previsto no artigo $5^{\circ}$, XVII, da Constituição da República, reclama o manejo de uma imputação penal que escapa dos parâmetros tradicionais, na medida em que a busca da responsabilidade penal das pessoas físicas que compõem a organização não pode ser concretizada ao largo de seus comportamentos.

Daí a existência de um movimento doutrinário que repele a constituição, pelo Direito Penal, de crimes de organização, sob o argumento de que eles violariam um sistema penal de conteúdo essencialmente democrático ${ }^{290}$.

De todo modo, ressalvado o posicionamento crítico, é incontestável a presença, no ordenamento jurídico brasileiro, de diversas manifestações coletivas que acabam por ensejar a incidência do Direito Penal. Impõe-se, assim, que examinemos a problemática questão do injusto penal e tentemos responder, ao final da nossa abordagem, à seguinte pergunta: o injusto penal cometido pelas organizações criminosas pode ser considerado um plus de desvalor se comparado ao injusto penal de seus componentes? $\mathrm{Ou}$,

\footnotetext{
${ }^{290}$ Para um panorama das críticas: CANCIO MELIÁ, Manuel; SILVA SÁNCHEZ, Jesús María. Delitos de organización, cit., p. 89-91. Ainda sob um aspecto crítico, Hassemer propõe a substituição da "prevenção normativa", marcada pelo recrudescimento do Direito Penal, por uma "prevenção técnica", "a qual impõe ao crime organizado obstáculos fáticos, organizacionais ou econômicos e o que desonera, de qualquer modo, a prevenção normativa e, parcialmente, pode substituí-la; ela exige utopia e não é de obtenção fácil, como os simples recrudescimento das leis" (HASSEMER, Winfried. Direito penal libertário. Belo Horizonte: Del Rey, 2007. p. 142-143).
} 
posto em outros termos, é possível cogitar uma responsabilidade penal da própria organização independentemente da responsabilidade de seus membros?

Manuel Cancio Meliá indica que o problema do injusto nos delitos de organização tem sido doutrinariamente abordado de três formas diversas ${ }^{291}$ : (i) em uma primeira vertente, mais antiga e com conteúdo mais amplo, o injusto encontra-se atrelado à ideia de abuso do direito fundamental de livre associação de pessoas; nessa esteira, o interesse penalmente tutelado pelo delito é o exercício do direito de associação; (ii) uma segunda tendência, denominada de teoria da antecipação ${ }^{292}$, vislumbra o injusto penal na antecipação da punibilidade, inclusive preconizando a punição antes de qualquer ato preparatório concreto, o que seria justificável somente naqueles casos em que a organização ostenta uma periculosidade exacerbada ${ }^{293}$; (iii) por fim, a terceira orientação doutrinária defende que a punição dos delitos de organização tome por base a violação de bens jurídicos de natureza coletiva, de onde se destacam a "paz pública", a "ordem pública", a "paz jurídica" etc.

A primeira orientação peca, de acordo com Cancio Meliá, pelo fato de não definir, com precisão, o objeto do injusto, limitando-se a uma referência excessivamente formal de um possível modo de cometer o crime ${ }^{294}$. Além disso, a nosso ver, parece injustificável ancorar o injusto no abuso ou deturpação do direito fundamental de associação, pois o artigo $5^{\circ}$, XVII, da Constituição da República, promove exclusivamente a tutela das associações formadas para fins lícitos, ou seja, mais do que simplesmente abusar ou conferir-se um fim socialmente inadequado, a associação criminosa vai de encontro ao dispositivo constitucional, violando-o frontalmente, pelo menos no sistema da Constituição de 1988.

A teoria da antecipação, a seu turno, tem sido criticada por restringir a análise do injusto penal ao momento de incidência da norma penal sem identificar, em

\footnotetext{
${ }^{291}$ CANCIO MELIÁ, Manuel; SILVA SÁNCHEZ, Jesús María. Delitos de organización, cit., p. 30-31.

${ }^{292}$ Id. Ibid., p. 37.

${ }^{293}$ Como assinala Cancio Meliá, a organização desenvolve uma dinâmica autônoma que acaba por minimizar as barreiras inibitórias individuais reduzindo, por força da estrutura interna da própria organização, as dificuldades técnicas para a comissão de condutas criminosas (CANCIO MELIÁ, Manuel; SILVA SÁNCHEZ, Jesús María. Delitos de organización, cit., p. 37).

${ }^{294}$ Id. Ibid., p. 36.
} 
contrapartida, o bem jurídico específico colocado em perigo com a constituição da organização. Dessa forma, à teoria da antecipação não resta outro caminho senão fundamentar o injusto nos crimes que eventualmente possam vir a ser praticados pelo ente coletivo e admitir que os delitos de organização traduzem, em verdade, meros delitos de perigo abstrato $^{295}$. Demais disso, a consideração de um único injusto, gerado exclusivamente pelos crimes praticados no seio da organização criminosa, se revela atentatória ao princípio do non bis in idem quando vislumbramos a hipótese de concurso de crimes. Concretamente: o sujeito " $\underline{X}$ ” que, por exemplo, cometeu crime de roubo valendose, para tanto, do fato de compor uma organização criminosa, será dupla e severamente apenado (pelo crime de organização criminosa e pelo crime de roubo), embora sua conduta tenha lesado um único bem jurídico (patrimônio) ${ }^{296}$.

A terceira e última corrente, que fundamenta o injusto penal das manifestações organizadas na proteção de bens jurídicos coletivos, tornou-se majoritária, como lembra Cancio Meliá, tanto na Espanha como na Alemanha ${ }^{297}$, o mesmo sucedendo com a doutrina ${ }^{298}$ e a jurisprudência ${ }^{299}$ brasileiras, o que, obviamente, não significa dizer que ela trafegue no ambiente acadêmico imune a críticas. Sim, porque, os termos "paz pública", "ordem pública”, "paz jurídica”, dentre outros manejados como objetos de proteção penal, são extremamente vagos, indeterminados, às vezes dúbios. Por conseguinte, não se pode afirmar, com rigor, se eles se referem a um sentimento de insegurança interno da população (aspecto subjetivo) ou a uma ideia objetivamente verificável atinente à paz pública ou à segurança (aspecto objetivo), ou aos dois ao mesmo tempo ${ }^{300}$.

${ }^{295}$ CANCIO MELIÁ, Manuel; SILVA SÁNCHEZ, Jesús María. Delitos de organización, cit., p. 37-39.

${ }^{296}$ A solução para esse problema residiria na sua qualificação como sendo um caso de concurso aparente de normas a ser resolvido com base no princípio da absorção ou consunção, de modo que o crime de quadrilha seja considerado um post factum impunível absorvido pelo crime de roubo.

${ }^{297}$ CANCIO MELIÁ, Manuel; SILVA SÁNCHEZ, Jesús María. Delitos de organización, cit., p. 31 e p. 42.

${ }^{298}$ HUNGRIA, Nélson. Comentários ao Código Penal. Rio de Janeiro: Forense, 1959. v. 9, p. 175; FRAGOSO, Heleno Cláudio. Lições de direito penal: parte especial. São Paulo: José Bushatsky, 1959. v. 3, p. 755.

${ }^{299}$ No STF: RHC 83447; no STJ: HC 73234; no TRF/2a Região: ACR 8842; no TRF/3 ${ }^{a}$ Região: Revisão

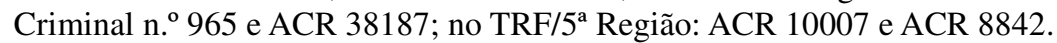

${ }^{300}$ CANCIO MELIÁ, Manuel; SILVA SÁNCHEZ, Jesús María. Delitos de organización, cit., p. 44. Para Cezar Roberto Bitencourt é exclusivamente o aspecto subjetivo o objeto jurídico protegido pelo crime de quadrilha: "O bem tutelado pelo tipo penal 'quadrilha ou bando', pode-se afirmar, é a paz pública sob o seu aspecto subjetivo, qual seja, a sensação coletiva de segurança e tranquilidade, garantida pela ordem jurídica, e não objetivo, como demonstrou Rocco" (BITENCOURT, Cezar Roberto. Tratado de direito penal. 6. ed. São Paulo: Saraiva, 2012. v. 4, p. 437, itálicos no original). 
Dessarte, o reproche mais comum a essa corrente teórica reside efetivamente no fato de a "paz pública" cristalizar conceito impalpável ou "pouco claro", para usar a expressão de $\operatorname{Roxin}^{301}$. A propósito, tratando de paz pública enquanto objeto de tutela penal, Claus Roxin manifesta-se de modo peremptório: "Continua não esclarecido como se deve imaginar a idoneidade para perturbar a paz pública nos casos em que inexiste lesão concreta à convivência pacífica"302.

Tendo presente essa situação de indefinição em relação ao bem jurídico e o fato de que eventual tipificação possa acarretar indevida antecipação da incidência penal, Antônio Sérgio Altieri de Moraes Pitombo propõe que se renuncie à criação de uma específica figura delituosa de natureza associativa, de sorte que o tipo da organização criminosa passe a figurar na Parte Geral do Código Penal, compondo a estrutura do concurso de agentes como causa de aumento de pena do artigo 29 do Estatuto Penal ${ }^{303}$.

Essa solução, porém, se nos afigura insuficiente por duas razões: (i) ignora a existência, no atual Direito Penal positivo brasileiro, de diversos tipos penais que preveem a agremiação de agentes como fator de incriminação autônoma ${ }^{304}$; (ii) desconsidera a influência dos entes coletivos e a consequente periculosidade de suas manifestações mais estruturadas.

Vale dizer: parece até mesmo intuitivo reconhecer que o desvalor dos crimes praticados através de organizações criminosas emerge consideravelmente maior do que aqueles levados a efeito individualmente ou sob concurso de agentes. A coletividade inegavelmente facilita e incentiva o cometimento de crimes primários, ou seja, aqueles que imediatamente proporcionaram a sua constituição (crimes-fim) e, além disso, propicia o aparecimento de crimes secundários (crimes-meio), concretizados com o intuito de ocultar os delitos anteriores, como acontece com a "lavagem" de dinheiro e as corrupções.

\footnotetext{
${ }^{301}$ ROXIN, Claus. Estudos de direito penal, cit., p. 51.

${ }^{302}$ Id. Ibid., p. 51.

${ }^{303}$ PITOMBO, Antônio Sérgio Altieri de Moraes. Organização criminosa, nova perspectiva do tipo legal, cit., p. $178-179$.

${ }^{304}$ Conquanto, a bem da verdade, as modalidade delitiva organizada mais importante do ordenamento brasileiro tenha surgido posteriormente à publicação da obra de Antônio Pitombo, em 2 de agosto de 2013, com a Lei n. ${ }^{\circ} 12.850$.
} 
Por conta disso, Joachim Lampe propõe a consideração do injusto da organização de modo separado do injusto de seu membro, que ele denomina "injusto de sistema" ou "injusto sistêmico"305. Esse injusto de sistema ultrapassaria o injusto individual e geraria, por conseguinte, uma nova modalidade de responsabilidade: a responsabilidade do sistema, que, para além da responsabilidade pela própria conduta, adicionaria o comportamento de outro coautor sistematicamente vinculado ${ }^{306}$. Lampe observa, contudo, que a organização enseja a criação de um injusto próprio (sistêmico) quando ela se revela formalmente organizada ou, para usar a sua terminologia, quando existe um "sistema constituído", que não se confunde com a mera soma das partes ${ }^{307}$.

A existência de uma estrutura destinada à atividade delituosa apresenta potencial para que tratemos o injusto penal da organização de modo apartado do injusto derivado do comportamento individual de seus membros ${ }^{308}$. Para Lampe, essa constatação deriva de quatro fatores que compõem o conteúdo do injusto: (i) a coletividade produz uma sinergia entre os membros que aumenta o potencial de risco e a diferencia da simples conjugação de esforços; (ii) existe um ataque organizado contra bens jurídicos; (iii) a organização produz uma sensação de unidade entre seus componentes (sentimento de comunidade); e (iv) toda a organização se orienta no sentido de praticar crimes ${ }^{309}$.

Uma vez verificados esses quatros fatores incide o injusto a despeito de qualquer conduta concreta do componente ${ }^{310}$. Como afirma Lampe, "Se trata de un injusto que no precisa de ninguna manifestación externa en sí a través de acciones: la agrupación criminal es un sistema de injusto en cuanto nazca como tal"311.

\footnotetext{
${ }^{305}$ LAMPE, Joachim. Injusto del sistema y sistemas de injusto: modelos de autorresponsabilidad penal empresarial, propuestas globales contemporáneas. Bogotá: Universidad Externado de Colombia, 2008. p. 63.

${ }^{306}$ Id. Ibid., p. 64.

${ }^{307}$ Id. Ibid., p. 68.

${ }^{308}$ Mesmo porque como se tem afirmado no âmbito da sociologia das organizações, "as organizações têm vida própria e, quando um indivíduo delas se afasta por qualquer motivo, aquele que irá ocupar o seu lugar deverá, em sua essência, fazer tudo que o anterior fazia. Isto significa que a estrutura da organização apresenta uma relativa estabilidade e independe dos indivíduos que a compõem, constituindo-se numa rede de papéis e posições sociais (status) que configuram sua identidade como uma organização específica voltada para atingir determinados fins" (DIAS, Reinaldo. Sociologia das organizações, cit., 159).

${ }^{309}$ LAMPE, Joachim. Injusto del sistema y sistemas de injusto: modelos de autorresponsabilidad penal empresarial, propuestas globales contemporáneas, cit., p. 87-89.

${ }^{310}$ Id. Ibid., p. 88.

${ }^{311}$ Id. Ibid., p. 88.
} 
Sob a particular óptica das organizações empresariais com tendência criminal, isto é, aquelas sociedades empresárias que, ao contrário das organizações criminosas, não são criadas com o propósito pioneiro e imediato de praticar crimes, de sorte que a atividade criminosa surge de modo acidental, Lampe entende que a constatação do injusto (sistêmico) depende da existência, ou não, de uma organização deficiente da empresa $^{312}$. Isso pode ocorrer de dois modos: quando o ente empresarial encontra-se imbuído de uma "filosofia empresarial criminógena" que reduz a barreira psicológica para o desenvolvimento da atividade deletéria ou quando ela favorece estruturalmente uma "atitude criminosa",313.

Em conformidade com Lampe, são, portanto, quatro as causas que delineiam o injusto do sistema no âmbito empresarial: "1. El peligro potencial de la empresa que se utiliza mecánica o lógicamente para la producción de la prestación; 2. la estructura deficitaria de la organización, la cual neutraliza sólo parcialmente la peligrosidad de este potencial; 3. La filosofía empresarial criminógena, la cual ofrece a los miembros de la organización la tentación de llevar a cabo acciones criminales; 4. La erosión del concepto de la responsabilidad por la acción individual, lo cual conduce, a nivel regulativo, a la evitación de la responsabilidad por hechos concretos, y, a nivel de la acción, conduce a una evitación de la responsabilidad derivada de las consecuencias de la obediencia a las reglas" ${ }^{, 314}$.

Abordando a problemática sob o prisma das organizações criminosas, Laura Zúñiga Rodríguez destaca três requisitos para a formulação do injusto: (i) a organização; (ii) a finalidade delitiva; e (iii) o cometimento de crimes graves. Esses três elementos são considerados básicos e, portanto, devem constar em todas as normas penais incriminadoras $^{315}$. Para Zúñiga Rodríguez, quando observamos o requisito da (i) organização, estamos a falar particularmente de uma estrutura permanente e de caráter estável de pessoas marcada pela divisão de tarefas de modo sistemático e pela presença de

\footnotetext{
${ }^{312}$ LAMPE, Joachim. Injusto del sistema y sistemas de injusto: modelos de autorresponsabilidad penal empresarial, propuestas globales contemporáneas, cit., p. 81.

${ }^{313}$ Id. Ibid., p. 82.

${ }^{314}$ Id. Ibid., p. 82.

${ }^{315}$ ZÚÑIGA RODRÍGUEZ Laura. Criminalidad organizada y sistema de derecho penal: contribución a la determinación del injusto penal de organización criminal, cit., p. 269.
} 
um órgão diretivo, ou seja, que toma decisões ${ }^{316}$. Nesse requisito insere-se, evidentemente, a pluralidade de membros. Para Zúñiga Rodríguez, devem ser pelo menos três para a existência de uma verdadeira organização ${ }^{317}$. Não obstante, o que fundamenta a organização e lhe outorga autonomia é a estrutura e a divisão de funções entre os membros $^{318} 319$. A (ii) finalidade delitiva, por sua vez, é o elemento subjetivo que sustenta a estrutura organizacional e diferencia as organizações criminosas de outras manifestações coletivas que não são originariamente delitivas, como as pessoas jurídicas ${ }^{320}$. Por fim, na perspectiva de Laura Zúñiga Rodríguez, a organização criminosa nasce tão-somente com o (iii) desiderato de cometer crimes graves (crimes-fim), ainda que não se venha a efetivamente praticá-los. Basta, dessa forma, a presença de um programa deliquencial para a configuração da organização ${ }^{321}$. Esse programa deliquencial pressupõe um acordo societário (pactum sceleris) e a presença de um plano desencadeado com o propósito primordial de obter lucro ${ }^{322}$.

A estruturação de um programa delitivo, destaca Zúñiga Rodríguez ${ }^{323}$, enseja o aparecimento de regras de funcionamento, as quais se revelam tanto interna como externamente. No primeiro caso são criadas convenções normalmente não escritas assumidas pelos membros da organização e que dizem respeito à distribuição de tarefas e

\footnotetext{
${ }^{316}$ Esse requisito encontra-se vinculado à ideia de autoconservação da própria organização, expressando o princípio da "ultraestabilidade". Isso significa que a organização tem "vida própria", ou seja, existe independente da saída ou do ingresso de membros, os quais são relativamente fungíveis, a depender do patamar hierárquico que ocupam (ZÚÑIGA RODRÍGUEZ Laura. Criminalidad organizada y sistema de derecho penal: contribución a la determinación del injusto penal de organización criminal, cit., p. 269).

${ }^{317}$ Id. Ibid., p. 270.

${ }^{318}$ Id. Ibid., p. 270.

${ }^{319}$ Exsurge cristalina a ideia, para Laura Zúñiga, que no interior da organização criminosa existem graus de responsabilidade, o que deve ser medido em conformidade com o grau de integração do sujeito no ente coletivo. Nessa esteira, é possível em dois níveis: (i) a posição ou função do sujeito na organização e (ii) sua contribuição ao programa criminal, a disposição para colocar em curso o programa deliquencial e não propriamente o cometimento concreto de crimes (Id. Ibid., p. 276).

${ }^{320}$ Id. Ibid., p. 271.

${ }^{321}$ Id. Ibid., p. 271. Como destaca Laura Zúñiga, discute-se no plano doutrinário a pertinência de um catálogo editado em numerus clausus contendo todas as infrações consideradas graves, ou uma simples e genérica menção à gravidade da pena (Id. Ibid., p. 273). Para Zúñiga é preferível um rol de crimes previamente definido em homenagem ao princípio da taxatividade (Id. Ibid., p. 273). Consoante mencionado anteriormente, o legislador brasileiro adotou a segunda opção em relação à Lei n. ${ }^{\circ}$ 12.850/2013, vinculando a punição à prática de infrações penais cujas penas máximas sejam superiores a 4 (quatro) anos, ou que sejam de caráter transnacional.

${ }^{322}$ Id. Ibid., p. 275. Mais uma vez é imperioso registrar que a Lei n. ${ }^{\circ}$ 12.850/2013 distanciou-se dessa realidade, na medida em que dispensou a finalidade de obter lucro para a caracterização da organização criminosa, exigindo-se, no artigo $1^{\circ}, \S 1^{\circ}$, "vantagem de qualquer natureza".

${ }^{323}$ Id. Ibid., p. 274-275.
} 
às relações entre seus próprios componentes. No segundo, são estabelecidas as formas de contato da agremiação criminosa com o mundo externo, ou seja, "acuerdos sobre cómo se relaciona la organización con otras organizaciones criminales, con el Estado, con las fuerzas del orden, con la Política, con los poderes económicos, que dibujan las características de la organización" ${ }^{324}$.

Manuel Cancio Meliá também defende a existência de um injusto específico para as organizações, lastreado primordialmente no perigo gerado pela constituição da própria organização, na existência do coletivo, e não no perigo proporcionado aos bens jurídicos. Para Cancio Meliá a organização emerge com magnitude social autônoma e, desse modo, pode se converter em um agente jurídico-penalmente relevante, notadamente se admitirmos que, em âmbitos extensos, as regras relativas à autoria e participação consubstanciam "letra morta",325.

Entretanto, Cancio Meliá restringe o injusto somente àquelas situações nas quais a organização arvora-se no exercício de direitos pertencentes ao âmbito de soberania do Estado, mais precisamente quando ela coloca em xeque o monopólio de violência que corresponde ao Estado, o que sucede visivelmente com as organizações terroristas, mas que também pode ser ampliado para as organizações criminosas ${ }^{326}$. "Somente o exercício de uma disciplina que inclua a atuação delitiva violenta (de dentro e de fora da organização) - assinala Manuel Cancio Meliá - questiona o papel do Estado, e por isso ataca especificamente o monopólio de violência estabelecido em seu favor, ${ }^{, 327}$.

\footnotetext{
${ }^{324}$ ZÚÑIGA RODRÍGUEZ Laura. Criminalidad organizada y sistema de derecho penal: contribución a la determinación del injusto penal de organización criminal, cit., p. 265. Não é ocioso relembrar que o legislador brasileiro, atento a essa realidade, estabeleceu causas de agravamento de pena ao crime do artigo $2^{\circ}$ da Lei n. ${ }^{\circ} 12.850 / 2013$ nos seguintes termos: Art. $2^{\circ}$, $4^{\circ}$ A pena é aumentada de 1/6 (um sexto) a 2/3 (dois terços): (...) II - se há concurso de funcionário público, valendo-se a organização criminosa dessa condição para a prática de infração penal; III - se o produto ou proveito da infração penal destinar-se, no todo ou em parte, ao exterior; IV - se a organização criminosa mantém conexão com outras organizações criminosas independentes; V - se as circunstâncias do fato evidenciarem a transnacionalidade da organização.

${ }^{325}$ CANCIO MELIÁ. El injusto de los delitos de organización: peligro y significado. Política criminal en vanguardia, inmigración clandestina, terrorismo, criminalidad organizada. Navarra: Editorial Aranzadi, 2008. p. 420 e p. $423-425$.

${ }^{326}$ Id. Ibid., p. 430 e p. 434. Para Manuel Cancio Meliá, não pode ser considerada uma associação criminosa qualquer agrupamento cujo objeto seja a perpetração de delitos; para gerar uma potencial ameaça que realmente possa ser entendida em termos de desafio ao Estado, será necessário um determinado grau de força - de estruturação interna - da organização (Id. Ibid., p. 436).

${ }^{327}$ Id. Ibid., p. 431.
} 
Nesse sentido, Cancio Meliá conclui pela necessidade de uma redefinição legislativa do tipo de organização criminosa para adequá-lo ao injusto, uma proposta de lege ferenda, em ordem a que o tipo de organização criminosa seja manejado exclusivamente quando houver violência ad intra ou ad extra ${ }^{328}$.

A posição de Jesús María Silva Sánchez é substancialmente diversa. Para ele, não se pode falar na existência de um injusto próprio da organização delitiva a ser valorado independentemente de um comportamento individual realizado pelo membro da agremiação criminosa $^{329}$. Com efeito, para Silva Sánchez a organização não tem capacidade de, por si mesma, praticar conduta alguma e, assim, considerada isoladamente, sua existência não pode lesar bens jurídicos. Daí a cogitação de um injusto somente em razão de um "estado de coisas" objetivamente favorecedor da perpetração de delitos pelos membros que compõem a associação ilícita ${ }^{330}$.

Desse ponto de vista, observa Silva Sánchez que a organização aparece como uma instituição portadora de um sistema de garantias favorecedor dos fatos criminosos praticados por seus membros. Esse sistema de garantias pode ser observado sob um duplo enfoque: de um lado, garante a subsistência do risco criado pelo membro; de outro, garante a conexão do referido risco com aquele gerado pelos membros que intervém no crime concretamente praticado ${ }^{331}$.

\subsection{Imputação penal nos delitos de organização}

O Direito Penal, como evidencia Lampe, é um Direito Penal essencialmente individual $^{332}$. Isso significa, em termos concretos, que a elaboração da imputação penal em ambientes organizados traz consigo, naturalmente, um fator de dificuldade, de

\footnotetext{
${ }^{328}$ CANCIO MELIÁ. El injusto de los delitos de organización: peligro y significado. Política criminal en vanguardia, inmigración clandestina, terrorismo, criminalidad organizada, cit., p. 432.

${ }^{329}$ CANCIO MELIÁ, Manuel; SILVA SÁNCHEZ, Jesús María. Delitos de organización, cit., p. 97-98.

${ }^{330}$ Id. Ibid., p. 99.

${ }^{331}$ Id. Ibid., p. 108.

${ }^{332}$ LAMPE, Joachim. Injusto del sistema y sistemas de injusto: modelos de autorresponsabilidad penal empresarial, propuestas globales contemporáneas, cit., p. 57.
} 
complexidade prática, pois os instrumentos jurídicos pertinentes à atribuição de responsabilidade são forjados invariavelmente com o propósito de resolver condutas individuais, as quais, no mais das vezes, percorreram, em grande medida, o iter criminis originariamente idealizado. Aplicam-se os critérios comumente utilizados para verificação da relação causal e, por consequência, para a incidência dos institutos da autoria e da participação $^{333}$.

Todavia, consoante assentado, no que tange ao injusto do sistema, as ações e os cursos causais lineares, assim como a teoria da equivalência, não oferecem critério algum de imputação penal ${ }^{334}$. O fato, analisado como um todo, surge de uma relação sistêmica; as causas e a responsabilidade se entrelaçam formando uma espécie de rede. Esse raciocínio, em conformidade com Lampe, se amolda perfeitamente aos ditos sistemas complexos, em que as contribuições individuais no seio do grupo somente podem ser apreciadas corretamente se levarmos em conta sua finalidade criminal e sua organização funcional $^{335}$.

Ao contemplar a ideia de que existem dois injustos interrelacionados, o chamado injusto sistêmico e aquele concretizado pelo indivíduo no contexto da organização, ensejador de uma "responsabilidade sistêmica em coautoria"336, Lampe sustenta a imprescindibilidade de uma dupla responsabilização penal, uma pela constituição ou integração ao sistema, outra pelo ataque ao bem jurídico no marco da organização.

Sobre o específico caso das organizações criminosas, Lampe observa que "el injusto de la existencia del sistema radica en la amenaza constante a la paz jurídica de la comunidad; el de la acción individual radica en la lesión o puesta en peligro del bien jurídico. Ambos sólo pueden ser objeto de una respuesta cumulativa"337.

\footnotetext{
${ }^{333}$ Nesse sentido: ZÚÑIGA RODRÍGUEZ Laura. Criminalidad organizada y sistema de derecho penal: contribución a la determinación del injusto penal de organización criminal, cit., p. 260.

${ }^{334}$ LAMPE, Joachim. Injusto del sistema y sistemas de injusto: modelos de autorresponsabilidad penal empresarial, propuestas globales contemporáneas, cit., p. 60.

${ }^{335}$ Id. Ibid., p. 60. Com idêntica proposta: ROXIN, Claus. Autoría y dominio del hecho en derecho penal, cit., p. 270.

${ }^{336}$ LAMPE, Joachim. Injusto del sistema y sistemas de injusto: modelos de autorresponsabilidad penal empresarial, propuestas globales contemporáneas, cit., p. 99.

${ }^{337}$ Id. Ibid., p. 100.
} 
De outro lado, Mem relação às organizações empresariais e baseando-se no fato de que a imputação das pessoas físicas somente pode ocorrer quando verificado um injusto com fundamento na "filosofia empresarial criminógena" ou na estruturação de uma "atitude criminosa", Joachim Lampe preconiza, de lege ferenda, que se responsabilize a própria pessoa jurídica ${ }^{338} \mathrm{e}$, paralelamente, as pessoas físicas que integram a empresa.

Para a primeira hipótese (filosofia empresarial criminógena), poder-se-á cogitar de imputação penal mediante coautoria para aqueles membros do grupo que, em razão de sua posição na empresa, têm a função de impedir a perpetração de crimes, de conformar o espírito ético-corporativo, enfim, proteger a empresa da "infiltração criminal”339, ou, ainda, para aqueles que, nos moldes das organizações criminosas, tomaram parte diretamente de um comportamento delituoso ${ }^{340}$.

Para o segundo grupo (criação de uma estrutura que viabilize a atitude criminosa), Lampe assinala que a imputação dos membros do ente empresarial deve centrar-se na ideia de que os dirigentes da organização empresarial têm o dever de criar âmbitos de conformação social e às normas de governança corporativa, bem como cuidar para que as regras de controle e de prevenção de atividades delituosas sejam fielmente cumpridas. Em caso de descumprimento ou cumprimento defeituoso dessas regras, haveria espaço para a punição desses dirigentes e para os sujeitos que atuaram diretamente na empreitada criminosa com base na posição de garante ${ }^{341}$.

Silva Sánchez, de outro lado, critica a existência de um "injusto sistêmico" cuja aplicação redundaria em uma responsabilização de índole coletiva violadora, na sua visão, do postulado do Direito Penal do Autor. Silva Sánchez não admite, como assentado anteriormente, a existência de um injusto próprio da organização delitiva a ser considerado independentemente de um comportamento individual realizado pelo membro da

\footnotetext{
${ }^{338} \mathrm{~A}$ responsabilidade penal das pessoas jurídica tem sido reservada, segundo assentado anteriormente, aos crimes contra o meio ambiente. Não obstante, não se pode deixar de mencionar a publicação recente da Lei n. ${ }^{\circ} 12.846 / 2013$, que dispõe sobre a responsabilização administrativa e civil de pessoas jurídicas pela prática de atos contra a administração pública, nacional ou estrangeira. Esta lei não tem conteúdo penal, mas traz relevantes critérios de responsabilização que podem servir na formulação da imputação penal de fatos praticados no seio de organizações empresariais.

${ }^{339} \mathrm{O}$ que ocorre com o indivíduo que tem a função de compliance, por exemplo.

${ }^{340}$ LAMPE, Joachim. Injusto del sistema y sistemas de injusto: modelos de autorresponsabilidad penal empresarial, propuestas globales contemporáneas, cit., p. 107-108.

${ }^{341}$ Id. Ibid., p. 108.
} 
agremiação; dessa forma, a imputação penal (individual) dos membros da organização deve levar em consideração a criação de riscos para os bens jurídicos protegidos pelos delitos-fim ${ }^{342}$.

Sob esse contexto, examinando a problemática da imputação penal no âmbito das organizações criminosas, Silva Sánchez observa que existem dois modelos de atribuição de responsabilidade: o (i) modelo de transferência e o (ii) modelo de responsabilidade por fato próprio. O primeiro modelo fundamenta a responsabilidade penal independentemente de analisar se a estrutura organizacional facilitou ou incentivou, de algum modo, a perpetração concreta dos delitos-fim. Neste caso, o motivo principal para a sanção penal reside no perigo constante e permanente criado pela constituição da organização criminosa à paz e à segurança pública ${ }^{343}$. Esse modelo de imputação cria um “delito de adesão" ou de mero pertencimento, critica Silva Sánchez que, ao fim e ao cabo, gera transferência de responsabilidade penal. Concretamente: o membro é responsabilizado penalmente pelo fato tão-somente de "ser" da organização criminosa, restando prescindível perquirir sobre a prática efetiva de qualquer delito ${ }^{344}$. Como aponta Silva Sánchez, "Ello constituye un expediente de imputación individual de un hecho colectivo no fácil de fundamentar, puesto que el miembro concreto da la organización (a diferencia de sus directores) en absoluto domina la peligrosidad de ésta (sino, en todo caso, a la inversa)"345.

O segundo modelo de imputação (por fato próprio) reclama, ao revés, que se analise a contribuição concreta de cada componente da organização para a compreensão de sua responsabilidade penal. Com isso, não se transfere ao membro o perigo criado exclusivamente pela organização criminosa. A base da imputação lastreia-se no fato de que o membro favoreceu, com o seu comportamento, o cometimento de crimes ${ }^{346}$.

Esse modelo de atribuição de responsabilidade penal, segundo a proposição de Silva Sánchez, apresentaria duas variações, quais sejam: (a) responsabilidade qualificada pela participação nos delitos cometidos segundo as regras gerais; (b) e

\footnotetext{
${ }^{342}$ CANCIO MELIÁ, Manuel; SILVA SÁNCHEZ, Jesús María. Delitos de organización, cit., p. 100.

${ }^{343}$ Id. Ibid., p. 102.

${ }^{344}$ Id. Ibid., p. 102-103.

${ }^{345}$ Id. Ibid., p. 103. Dar azo a um Direito Penal meramente simbólico e guiar-se exclusivamente pela facilitação da prova são outras duas críticas mencionadas por Silva Sánchez (Id. Ibid., p. 103-104).

${ }^{346}$ Id. Ibid., p. 105.
} 
responsabilidade por intervenção através de uma organização.

No primeiro caso, tem-se responsabilidade penal apenas quando houver participação em delitos efetivamente praticados no marco da organização; nesta hipótese, a sanção deverá ser qualificada em atenção à maior reprovabilidade da conduta, haja vista a estabilidade e a permanência da organização ${ }^{347}$.

$\mathrm{Na}$ segunda variação, visivelmente mais simpática aos olhos de Silva Sánchez, parte-se do pressuposto que a existência de uma organização delituosa não representa um simples elemento qualificador da intervenção dos agentes (membros) na realização dos delitos-fim, mas uma realidade institucional que acaba por influenciar as relações e o comportamento de seus membros. Nessa esteira, ela não dispensa a presença de um crime (em concreto), isto é, continua a exigir, no juízo da imputação penal, a comissão de um delito por parte de algum membro da organização ${ }^{348}$.

Como acrescenta Silva Sánchez, a organização tem uma "doble función de garantía (delictiva): por un lado, garantiza la pervivencia del riesgo creado por un miembro; por el otro, garantiza la conexión de dicho riesgo con el generado por los intervinientes en un hecho delictivo concreto" ${ }^{349}$.

Daí decorrerem as seguintes conclusões para Silva Sánchez: (i) o comportamento passivo do membro da organização, caracterizado pela mera assunção da sua condição como componente da agremiação criminosa, não gera imputação penal; (ii) aqueles membros considerados "esporadicamente ativos", ou seja, que eventualmente tomam parte de concretas condutas delituosas, podem ser responsabilizados penalmente quando a favorecerem de forma direta e imediata; (iii) os membros institucionalmente ativos respondem a título de coautoria ou participação em qualquer dos crimes concretamente perpetrados no contexto e em benefício da organização (delitos-fim). Do ponto de vista subjetivo, ao emprestarem suas condutas às finalidades criminosas da organização, os membros agem como dolo alternativo; (iv) a consideração da participação por intermédio da organização depende da criação de um risco relevante aos bens jurídicos

\footnotetext{
${ }^{347}$ CANCIO MELIÁ, Manuel; SILVA SÁNCHEZ, Jesús María. Delitos de organización, cit., p. 106.

${ }^{348}$ Id. Ibid., p. 110-111.

${ }^{349}$ Id. Ibid., p. 108.
} 
concretamente lesionados ${ }^{350}$.

Manuel Cancio Meliá, a seu turno, defende que a imputação penal no seio das organizações passe pela compreensão, de resto anotada alhures, de que existe um injusto específico para a coletividade. Dessa forma, Cancio Meliá observa que o que importa, no juízo de atribuição de responsabilidade penal, é o grau de integração do sujeito na organização ${ }^{351}$. E isso porque a integração acarreta, para Cancio Meliá, uma perda de controle do sujeito que se refere não somente aos eventuais e futuros crimes futuros, mas também à sua própria condição de membro da organização ${ }^{352}$, acabando por converter a atuação coletiva da organização na conduta de cada um de seus membros ${ }^{353}$. A integração do sujeito ao ente coletivo é repleta de significado e, assim, consubstancia o eixo fundamental do juízo de imputação penal ${ }^{354}$.

Diante desse contexto, Cancio Meliá distingue, no marco da organização, as figuras do integrante e do colaborador, elaborando o seguinte raciocínio: "el agente que se integra en la organización lleva a cabo una conducta descrita ex re claramente como perturbadora: ha orientado, 'adaptado' su comportamiento de tal modo que ya no es posible una interpretación como conducta irrelevante. Mientras que en el caso de la colaboración con la organización, cobrará especial importancia la elaboración del nivel del riesgo permitido en atención a la adecuación social del tipo de conducta en cuestión, en el ámbito de la integración en la organización delictiva - de nuevo sea dicho: si la organización y el acto de integración se definen de modo adecuado - no planteará muchas dificultades en este punto" ${ }^{\text {355 }}$.

\footnotetext{
${ }^{350}$ CANCIO MELIÁ, Manuel; SILVA SÁNCHEZ, Jesús María. Delitos de organización, cit., p. 117-118.

${ }^{351}$ Id. Ibid., p. 84.

${ }^{352}$ Id. Ibid., p. 70.

${ }^{353}$ Id. Ibid., p. 70

${ }^{354}$ Id. Ibid., p. 72. Cancio Meliá, nesse caso, parece inspirar-se nas concepções de Günther Jakobs acerca dos crimes de organização. Jakobs assinala, no ponto, que no âmbito das organizações a realização de atos criminosos não pode ser atribuída exclusivamente ao autor, pois ela será obra de todos os demais membros, autores e partícipes. Dessa forma, compõem a coletividade, e se lhe imputam os atos danosos por ela perpetrados, todas as pessoas que se "organizaram de modo tal que a organização objetivamente tenha sentido para alcançar consequências delitivas; a expressão de sentido de quem realiza atos de execução deve ser imputada a esses sujeitos como o sentido que eles mesmos perseguiam" (JAKOBS, Günther. A imputação objetiva no direito penal, cit., p. 61).

${ }^{355}$ CANCIO MELIÁ, Manuel; SILVA SÁNCHEZ, Jesús María. Delitos de organización, cit., p. 72.
} 
A concepção que sustenta a existência de dois injustos autônomos, conquanto interrelacionados, ostenta, a nosso ver, o notável mérito de obstar a opção pelos extremos na atribuição de responsabilidade penal: impunidade ou punição desmesurada. Ambas as soluções são manifestamente insatisfatórias e causam fricções com o princípio da culpabilidade, como recorda Laura Zúñiga Rodríguez ${ }^{356}$.

Zúñiga Rodríguez, a propósito, proclama que a única solução adequada aos princípios fundamentais de Direito Penal na concretização da imputação no âmbito das organizações criminosas reside na dupla imputação, vale dizer, ao agente que pratica um fato criminoso valendo-se ou se favorecendo da estrutura da organização devem ser atribuídos dois injustos diversos, embora correlacionados: o primeiro relacionado ao fato criminoso efetivamente praticado (roubo, furto, tráfico de entorpecentes etc.), a ser dirimido em consonância com as regras típicas de autoria e de participação; o segundo, pela participação em uma organização criminosa ${ }^{357}$.

Dessa forma, havendo ausência de prática delitiva concreta pelo componente da organização, incidirá um único injusto, o da própria organização, porquanto estrutura e funcionalmente ordenada para esse desiderato ${ }^{358}$.

O grau de integração do membro na organização também é um elemento relevante para Zúñiga Rodríguez, que chega a propor dois critérios para a atribuição de responsabilidade penal: (i) a posição ou função do sujeito na organização e (ii) sua contribuição ao programa deliquencial, o que deve ser aferido ao largo da consideração do fato delituoso concreto. No primeiro critério, avulta a importância dos líderes, dos chefes da organização; a imputação, aqui, deve ser realizada com esteio na teoria do domínio do fato, de Claus Roxin, haja vista que os líderes detêm o domínio da organização e, ademais, ostentam função de vigilância sobre os delitos que vierem a ser perpetrados no bojo da organização $^{359}$. Para a segunda hipótese, Zúñiga Rodríguez propõe a análise do comportamento do colaborador com foco na sua relevância para a o desate do programa criminoso. Para essa operação, ela preconiza a utilização da teoria da imputação objetiva,

\footnotetext{
${ }^{356}$ ZÚÑIGA RODRÍGUEZ Laura. Criminalidad organizada y sistema de derecho penal: contribución a la determinación del injusto penal de organización criminal, cit., p. 260.

${ }^{357}$ Id. Ibid., p. 260.

${ }^{358}$ Id. Ibid., p. 262.

${ }^{359}$ Id. Ibid., p. 277.
} 
de criação ou incremento do risco, "siempre teniendo en cuenta que el resultado es la permanencia de la estructura de la organización criminal, no el delito concreto"360.

\subsection{Quadrilha, associação criminosa e organizações criminosas}

O Direito Penal brasileiro não passou incólume ao movimento expansionista e recentemente passou a contemplar, em seu ordenamento jurídico, típicos delitos de organização. Para a consecução do presente trabalho serão analisados os aspectos mais importantes dos delitos de quadrilha ou bando, de associação criminosa e de organização criminosa, em ordem a estabelecer, em um segundo momento, a comparação dessas estruturas coletivas com as organizações empresariais, notadamente as complexas.

\subsubsection{Quadrilha ou bando e as associações criminosas}

O crime de quadrilha ou bando possuía definição típica no artigo 288 do Código Penal: “Associarem-se mais de três pessoas, em quadrilha ou bando, para o fim de cometer crimes. Pena: reclusão, de 1 (um) a 3 (três) anos. Parágrafo único: A pena aplica-se em dobro, se a quadrilha ou bando é armado".

A doutrina brasileira sempre tratou as expressões quadrilha e bando como sinônimas ${ }^{361}$, embora exista entendimento que o termo quadrilha deve ser reservado às agremiações criminosas que se formam em ambientes urbanos, enquanto bando à união de agentes com a finalidade de praticar delitos em ambientes rurais, no interior do país ${ }^{362}$.

\footnotetext{
${ }^{360}$ ZÚÑIGA RODRÍGUEZ Laura. Criminalidad organizada y sistema de derecho penal: contribución a la determinación del injusto penal de organización criminal, cit., p. 278. Com a adoção desse critério, Laura Zúñiga Rodríguez procura, inclusive, separar, na conduta dos colaboradores da organização criminosa, aquilo que pode ser imputado, visto que relevante do ponto de vista da organização criminosa, daquilo que constitui uma ação neutra (Op. Cit., p. 277).

${ }^{361}$ FRAGOSO, Heleno Cláudio. Lições de direito penal: parte especial, cit., v. 3, p. 757.

${ }^{362}$ José Silva Junior, citando Ribeiro Pontes: Código Penal e sua interpretação jurisprudencial: parte especial. 6. ed. São Paulo: Ed. Revista dos Tribunais, 1997. v.1, t. 2, p. 3324. Galdino Siqueira também
} 
Essa discussão, contudo, perdeu parcialmente o sentido com o advento da Lei n. ${ }^{\circ}$ 12.850, publicada em 02 de agosto de 2013, que revogou a redação do artigo 288 do Estatuto Penal para nele esculpir o crime de associação criminosa nos seguintes termos: "Associarem-se 3 (três) ou mais pessoas, para o fim específico de cometer crimes: Pena reclusão, de 1 (um) a 3 (três) anos. Parágrafo único. A pena aumenta-se até a metade se a associação é armada ou se houver a participação de criança ou adolescente".

É certo que novel delito de associação criminosa manteve os requisitos básicos de seu precedente, à exceção óbvia do número de componentes. Não obstante, tal como sucedia no crime de quadrilha, a configuração penal da associação criminosa continua exigindo permanência e estabilidade, elementos, aliás, fundamentais na sua distinção para o concurso de agentes. Em outro dizer: a união ocasional de três ou mais indivíduos sem o estabelecimento de um plano ou programa deliquencial com vocação para a permanência não gera a incidência do tipo penal atualmente plasmado no artigo 288 do Código Penal, mas do artigo 29 do mesmo Diploma Legal.

Outras conclusões doutrinárias sedimentadas sob a égide do antigo artigo 288 também podem ser transportadas para o crime de associação criminosa sem qualquer violência ao princípio da tipicidade estrita. Assim, a caracterização da associação criminosa não reclama hierarquia e tampouco divisão de tarefas; ela dispensa, por conseguinte, a presença de um líder ou chefe que determine os passos e o destino da agremiação; não exige sofisticação ou a criação de códigos internos de conduta ${ }^{363}$.

A associação criminosa delineada no artigo 288 do Código representa, por assim dizer, a forma fundamental dessa infração penal, aplicando-se, por consequência, para todo e qualquer delito, excetuadas as contravenções penais. Dessa forma, na ausência

\footnotetext{
menciona a distinção terminológica, fazendo-o, todavia, nos seguintes termos: "Na linguagem vulgar, dizse quadrilha a horda de salteadores que obedecem a um chefe e cujo mister é roubar ou matar para roubar; diz-se do bando o grupo indisciplinado de malfeitores, entregue, também, a crimes com violência" (SIQUEIRA, Galdino. Tratado de direito penal: parte especial. 2. ed. Rio de Janeiro: José Konfino, 1951. t. 2, v. 4, p. 369).

${ }^{363}$ Nesse sentido: FERRAZ, Esther de Figueiredo. A co-delinquência no direito penal brasileiro, cit., p. 84. Contra, exigindo para a configuração do crime "um mínimo de organização hierárquica estável e harmônica, com distribuição de funções e obrigações organizativas": BITENCOURT, Cezar Roberto. Tratado de direito penal, v. 4, p. 439.
} 
de norma especial regendo o tema, aplicar-se-á o conceito geral do artigo 288 do Estatuto Penal.

Essa ressalva afigura-se pertinente quando se tem em perspectiva a presença, no ordenamento jurídico pátrio, de outras figuras associativas com conteúdo semelhante à associação criminosa e que, por essa mesma razão, exigirão, para a sua conformação, os mesmos requisitos de estabilidade e de permanência, além da pluralidade de pessoas. É o que acontece, por exemplo, com os crimes de associação para o tráfico de substâncias entorpecentes, da associação para o genocídio, de milícia privada, de associações definidas na Lei de Segurança Nacional ${ }^{364}$ e de lavagem de dinheiro pratica por intermédio de grupo, associação ou escritório. Todos esses casos reclamam, do ponto de vista típico, a existência de um programa deliquencial, "um ajuste prévio no sentido da formação do vínculo associativo de fato, uma verdadeira societas sceleris"365. Na ausência do elemento subjetivo que agrilhoa os componentes do grupo remanescerá exclusivamente coautoria ou participação.

\subsubsection{Organização criminosa: conceito e elementos identificadores}

De acordo com o artigo $1^{\circ}$, $\S 1^{\circ}$, da Lei n. ${ }^{\circ} 12.850 / 2013$, "Considera-se organização criminosa a associação de 4 (quatro) ou mais pessoas estruturalmente ordenada e caracterizada pela divisão de tarefas, ainda que informalmente, com objetivo de obter, direta ou indiretamente, vantagem de qualquer natureza, mediante a prática de infrações penais cujas penas máximas sejam superiores a 4 (quatro) anos, ou que sejam de caráter transnacional.

A conceituar organização criminosa, a Lei ${ }^{\circ}$ 12.850/2013 tentou encerrar um debate que há anos permeava o plano acadêmico e a jurisprudência, pois predominava

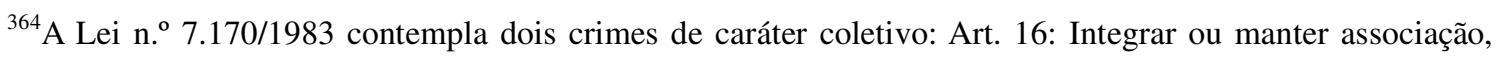
partido, comitê, entidade de classe ou grupamento que tenha por objetivo a mudança do regime vigente ou do Estado de Direito, por meios violentos ou com o emprego de grave ameaça. Pena: reclusão, de 1 a 5 anos; e Art. Art. 24: Constituir, integrar ou manter organização ilegal de tipo militar, de qualquer forma ou natureza armada ou não, com ou sem fardamento, com finalidade combativa. Pena: reclusão, de 2 a 8 anos. ${ }^{365}$ GRECO FILHO, Vicente; RASSI, João Daniel. Lei de drogas anotada: Lei n. 11.343/2006, cit., p. 128.
} 
o entendimento que a Lei n. ${ }^{\circ}$ 9.034/1995 não conceituava organização criminosa em nenhum de seus artigos ${ }^{366}$, embora tenha pretendido regular os meios de prova e os procedimentos investigatórios que "versem sobre ilícitos decorrentes de ações praticadas por quadrilha ou bando ou organizações ou associações criminosas de qualquer tipo"367.

A indefinição acerca de um claro conceito de organização criminosa provocou uma situação de extrema insegurança na aplicação dos preceitos de Direito Penal e de Direito Processual ${ }^{368}$ que não ficou restrita à corporificação de normas penais incriminadoras ${ }^{369}$, alcançando, também, institutos de caráter benéfico ao indivíduo ${ }^{370}$.

Sob esse contexto, formaram-se, então, quatro orientações, assim sintetizadas: (i) não existe conceito legal de organização criminosa e ele sequer precisa existir, haja vista a impossibilidade de restringir legalmente um fenômeno naturalmente fluído e indefinido ${ }^{371}$; (ii) o conceito deve ser extraído do (antigo) artigo 288 do Código

\footnotetext{
${ }^{366}$ ESTELLITA, Heloisa Criminalidade de empresa, quadrilha, e organização criminosa. Porto Alegre: Livr. do Advogado Ed., 2009. p. 59; e PITOMBO, Antônio Sérgio Altieri de Moraes. Organização criminosa, nova perspectiva do tipo legal, cit., p. 90. Contra: MAIA, Rodolfo Tigre. O Estado desorganizado contra o crime organizado: anotações à lei federal n. ${ }^{\circ}$ 9.034/95 (organizações criminosas). Rio de Janeiro: Lumen Juris, 1997. p. 55.

${ }^{367}$ Essa redação foi conferida pela Lei n. ${ }^{\circ} 10.217$, de 11 de abril de 2001.

${ }^{368}$ A ausência de um conceito claro de organização criminosa acarreta, para além de uma lacuna no sistema penal, um obstáculo processual que acaba interferindo na própria persecução penal, como bem observa Antonio Scarance Fernandes: "a falta de definição de organização criminosa impossibilita a restrição a direitos e garantias do investigado, do acusado, do condenado, com fundamento no fato de pertencer a esse tipo de entidade, por ofensa aos princípios da reserva legal e da proporcionalidade" (FERNANDES, Antonio Scarance. Crime organizado: aspectos processuais. São Paulo: Ed. Revista dos Tribunais, 2009. p. 15).

${ }^{369}$ Talvez o melhor exemplo da dificuldade criada pela ausência de um conceito claro de organização criminosa seja a sua consideração, como crime antecedente, da "lavagem" de dinheiro, na forma do que dispunha originariamente o artigo $1^{\circ}$, VII, da Lei n. ${ }^{\circ}$ 9.613/1998. Essa discussão, todavia, encontra-se superada hodiernamente em razão da edição da Lei n. ${ }^{\circ}$ 12.683/2012, que aboliu o catálogo taxativo de crimes antecedentes.

${ }^{370}$ É o caso do disposto no artigo $33, \S 4^{\circ}$, da Lei n. ${ }^{\circ} 11.343 / 2006$ : Nos delitos definidos no caput e no $\S 1^{\underline{0}}$ deste artigo, as penas poderão ser reduzidas de um sexto a dois terços, desde que o agente seja primário, de bons antecedentes, não se dedique às atividades criminosas nem integre organização criminosa.

${ }^{371}$ Esse é o entendimento de Vicente Greco Filho e de João Daniel Rassi: "Há quem sustente que a lei deveria ter dado os requisitos para que uma associação ou grupo se constitua em organização, mas não cremos que isso seria adequado, uma vez que as organizações são muito diferenciadas e uma definição restringiria o conceito, tornando impossível a sua identificação em face de exigências rígidas e expressas. O conceito deve manter-se fluido, como fluido é o próprio modo de ser de uma societas sceleris. Da doutrina, então, é que podem ser extraídas as características básicas de uma organização criminosa que podem não estar presentes em todos os casos, mas servem de base para o enquadramento jurídico da situação. São apontados os seguintes elementos para o reconhecimento de uma organização criminosa: 1 - Estrutura organizacional, com células relativamente estanques, de modo que uma não tem a identificação dos componentes da outra. 2 - Especialização de tarefas, de modo que cada uma exerce uma atividade predominante. Tomando como exemplo uma organização criminosa para o tráfico ilícito de entorpecentes, dir-se-ia que tem atividade definida o importador, o transportador, o destilador, o financeiro, o traficante de área e distribuidor e o
} 
Penal, com a seguinte ressalva: enquanto não houver a prática do crime que ensejou a constituição da agremiação criminosa (crime-fim) existe tão-somente quadrilha ou bando; se houver a prática de um ou mais delitos, tem-se organização criminosa ${ }^{372}$; (iii) o conceito de organização encontra-se delineado no artigo $2^{\circ}$ da Convenção de Palermo (Convenção das Nações Unidas contra o Crime Organizado Transnacional), internalizada no ordenamento jurídico brasileiro pelo Decreto 5.015/2004 ${ }^{373}$; (iv) não existe conceito de organização criminosa no ordenamento brasileiro; a Convenção de Palermo não consubstancia lei em sentido estrito (apenas tem força de lei), de modo que a sua utilização para fins de incriminação viola o princípio constitucional da reserva legal ${ }^{374}$.

Com o advento da Lei n. ${ }^{\circ}$ 12.850/2013, o Brasil adotou, em linhas gerais, o modelo internacional proposto pela Convenção de Palermo para caracterização de organizações criminosas, mormente por exigir a existência de um grupo estruturalmente ordenado marcado pela divisão de tarefas e atrelar a sua finalidade ao cometimento de

traficante local, como uma rede, das artérias aos vasos capilares. 3 - A existência de vários níveis de hierarquia, em que os subordinados nem sempre, ou quase nunca, conhecem a identidade da chefia de dois ou mais escalões superiores ou, ainda que conheçam a chefia mais elevada, não têm contato direto com ela e não podem fornecer provas a respeito. 4 - A possível existência de infiltração de membros da organização em atividades públicas, no Poder Executivo, Legislativo, Ministério Público e Judiciário e corrupção de agentes públicos. 5 - A tendência de durabilidade. 6 - A conexão com outras organizações, no mesmo ramo ou em ramo diferente, quando não a atividade em vários ramos. 7 - A coação, mediante violência, chantagem ou aproveitamento da condição de pessoas não participantes, mas que passam a ser auxiliares ou coniventes e que vivem sob a imposição de grave dano em caso de delação. 8 - Mais de três pessoas" (GRECO FILHO, Vicente; RASSI, João Daniel. Lei de drogas anotada: Lei n. 11.343/2006, cit., p. 76-77).

${ }^{372}$ Nesse sentido: MAIA, Rodolfo Tigre. O Estado desorganizado contra o crime organizado: anotações à lei federal n. ${ }^{\circ}$ 9.034/95 (organizações criminosas), cit., p. 55.

${ }^{373}$ A Convenção de Palermo não se utiliza da terminologia "organização criminosa", mencionando, ao revés, "Grupo criminoso organizado", ou seja, grupo estruturado de três ou mais pessoas, existente há algum tempo e atuando concertadamente com o propósito de cometer uma ou mais infrações graves ou enunciadas na presente Convenção, com a intenção de obter, direta ou indiretamente, um benefício econômico ou outro benefício material; "infração grave" é o ato que constitua infração punível com uma pena de privação de liberdade, cujo máximo não seja inferior a quatro anos ou com pena superior; "grupo estruturado" é o grupo formado de maneira não fortuita para a prática imediata de uma infração, ainda que os seus membros não tenham funções formalmente definidas, que não haja continuidade na sua composição e que não disponha de uma estrutura elaborada. No sentido da adoção da Convenção de Palermo, embora limitando a sua aplicação ao preenchimento das lacunas existentes na Lei n. ${ }^{\circ}$ 9.034/1995 e 9.613/1998, sem a força de um tipo penal, portanto: MORO, Sergio Fernando. Crime de lavagem de dinheiro. São Paulo: Saraiva, 2010. p. 39-40; BALTAZAR JUNIOR, José Paulo. Crime organizado e proibição de insuficiência. Porto Alegre: Livr. do Advogado Ed., 2010. p. 155; GODOY, Luiz Roberto Ungaretti de. Crime organizado e seu tratamento jurídico penal. Rio de Janeiro: Elsevier, 2011. p. 74.

${ }^{374}$ PITOMBO, Antônio Sérgio Altieri de Moraes. Organização criminosa, nova perspectiva do tipo legal, cit., p. 108-110. Na mesma esteira, mas particularmente sobre a insuficiência normativa da Convenção de Palermo, confira-se ESTELLITA, Heloisa Criminalidade de empresa, quadrilha, e organização criminosa, cit., p. 72. 
crimes graves ou de caráter transnacional, embora o nosso legislador tenha sido mais severo no que tange ao número mínimo de (quatro) componentes ${ }^{375}$. Não obstante, parece claro que a Lei n. ${ }^{\circ}$ 12.850/2013 se distanciou do padrão proposto pela doutrina estrangeira $^{376}$, na medida em que dispensou expressamente a finalidade de lucro como elemento caracterizador da organização criminosa, satisfazendo-se, ao revés, com a busca pela "vantagem de qualquer natureza".

Essa postura, além de inadequada por representar um corpo estranho na comunidade internacional, pode gerar situações conflituosas com outras figuras penais similares, com destaque para o terrorismo ${ }^{377}$. Com efeito, ambos os fenômenos são próximos, porquanto coletivos e organizados, e às vezes chegam até mesmo a se relacionar, dando azo a um "sistema de vaso comunicantes",378 deletério para a sociedade.

A distinção entre eles, segundo aponta a doutrina ${ }^{379}$, incide primordialmente na busca imediata pelo lucro (ilícito) pelas organizações criminosas, enquanto que as organizações terroristas procuram desestabilizar o Estado e suas instituições. Dessarte, ao

\footnotetext{
${ }^{375}$ Não podemos deixar de manifestar perplexidade com a notória divergência do conceito de organização criminosa adotado pela Lei $\mathrm{n}^{\circ} 12.850 / 2013$ com aquele contemplado no artigo $2^{\circ}$ da Lei n. $^{\circ} 12.694 / 2012$, que dispõe sobre o processo e o julgamento colegiado em primeiro grau de jurisdição de crimes praticados por organizações criminosas, a saber: "Para os efeitos desta Lei, considera-se organização criminosa a associação, de 3 (três) ou mais pessoas, estruturalmente ordenada e caracterizada pela divisão de tarefas, ainda que informalmente, com objetivo de obter, direta ou indiretamente, vantagem de qualquer natureza, mediante a prática de crimes cuja pena máxima seja igual ou superior a 4 (quatro) anos ou que sejam de caráter transnacional". Parece-nos que, no conflito aparente de normas quanto ao número mínimo de pessoas para a configuração da organização criminosa deverá prevalecer o conceito da Lei n. ${ }^{\circ}$ 12.850/2013, por ser mais rígido quando aos elementos do fenômeno delitivo organizado e, portanto, mais benéfico ao investigado ou acusado. Para Vicente Greco Filho o conceito de organização criminosa da Lei n. ${ }^{\circ}$ 12.694/2012 deve ficar restrito à formação do colegiado, ou seja, não se trata de um conceito de direito material (GRECO FILHO, Vicente. Considerações processuais da lei de julgamento de crimes envolvendo organização criminosa. Boletim do Instituto Brasileiro de Ciências Criminais, São Paulo, ano 20, n. 239, p. 2, out. 2012).

${ }^{376}$ BALTAZAR JUNIOR, José Paulo. Crime organizado e proibição de insuficiência, cit., p. 125.

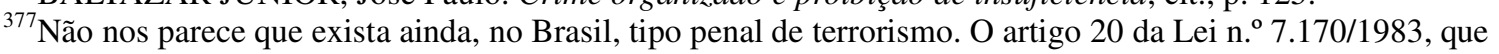
criminaliza a conduta de "Devastar, saquear, extorquir, roubar, sequestrar, manter em cárcere privado, incendiar, depredar, provocar explosão, praticar atentado pessoal ou atos de terrorismo, por inconformismo político ou para obtenção de fundos destinados à manutenção de organizações políticas clandestinas ou subversivas", cominando pena de reclusão, de 3 a 10 anos, é manifestamente inconstitucional (violação do princípio do mandato de certeza) por não definir concretamente o que vem a ser "atos de terrorismo". Nesse sentido: FRAGOSO, Heleno Cláudio. Terrorismo e criminalidade política. Rio de Janeiro: Forense, 1981. p. 98 e ss.

${ }^{378}$ PELLEGRINI, Angiolo; COSTA JR., Paulo José da. Criminalidade organizada. 2. ed. São Paulo: Atlas, 2008. p. 17.

${ }^{379}$ ZÚÑIGA RODRÍGUEZ Laura. Criminalidad organizada y sistema de derecho penal: contribución a la determinación del injusto penal de organización criminal, cit., p. 135-137. No mesmo sentido: FERRO, Ana Luíza Almeida. Crime organizado e organizações criminosas mundiais. Curitiba: Juruá, 2009. p. 345.
} 
não indicar a finalidade de lucro na composição do conceito de organização criminosa, o legislador brasileiro proporciona confusão entre essas duas importantes realidades e, por conseguinte, insegurança jurídica.

Posto isso, cumpre verificar, agora, quais os elementos identificadores das organizações criminosas para que, posteriormente, possamos cotejá-los com os elementos que delineiam as organizações empresariais, apresentando, em consequência, os aspectos diferenciadores e os aspectos comuns aos dois institutos jurídicos.

Partindo do critério sugerido por Laura Zúñiga Rodríguez, podemos analisar os elementos identificadores das organizações criminosas dividindo-os em dois grupos: (i) elementos essenciais e (ii) elementos contingentes ou acidentais.

No primeiro grupo, destacam-se a (i.i) organização, a (i.ii) finalidade de lucro e (i.iii) prática de crimes graves. No segundo grupo, indicam-se a (ii.i) busca pela impunidade; a (ii.ii) o secretismo; (ii.iii) as vinculações com mundo empresarial; a (ii.iv) as vinculações com o mundo político; (ii.v) a busca pelo domínio do mercado; e a (ii.vi) transnacionalidade ${ }^{380}$. Passemos à análise sumariada de cada elemento.

1. Organização: somente existirá uma organização criminosa quando houver a constituição de um grupo, isto é, de uma pluralidade de pessoas, estruturalmente ordenado à realização de um determinado fim comum. Esse grupo não nasce, a toda evidência, da ocasional conjugação de esforços, mas da criação de um plano ou programa comum de natureza estável que confere racionalidade à organização ${ }^{381}$. Esse plano comum

\footnotetext{
${ }^{380}$ ZÚÑIGA RODRÍGUEZ Laura. Criminalidad organizada y sistema de derecho penal: contribución a la determinación del injusto penal de organización criminal, cit., p. 126-149. Na mesma esteira: BALTAZAR JUNIOR, José Paulo. Crime organizado e proibição de insuficiência, cit., p. 124-145.

${ }^{381}$ ZÚÑIGA RODRÍGUEZ Laura. Criminalidad organizada y sistema de derecho penal: contribución a la determinación del injusto penal de organización criminal, cit., p. 128. A caracterização da organização criminosa prescinde da existência de regras de conduta escritas, mas é evidente que a existência de um "regulamento criminoso" constitui prova indubitável da estabilidade do aparato deliquencial. O Primeiro Comando da Capital (PCC), maior organização criminosa do Estado de São Paulo possui, por exemplo, um "Estatuto" com o seguinte teor: "01 - Lealdade, respeito e solidariedade acima de tudo ao Partido; 02 - A luta pela liberdade, justiça e paz; 03 - A união na luta contra as injustiças e a opressão dentro da prisão; 04 - Contribuição daqueles que estão em liberdade com os irmãos dentro da prisão, através de advogados, dinheiro, ajuda aos familiares e ação de resgate; 05 - $\mathrm{O}$ respeito e a solidariedade a todos os membros do Partido, para que não haja conflitos internos, porque aquele que causar conflito interno dentro do Partido, tentando dividir a irmandade, será excluído e repudiado do Partido; 06 - Jamais usar o Partido para resolver problemas pessoais contra pessoas de fora porque o ideal do Partido está acima de conflitos pessoais. Mas o Partido estará sempre leal e solidário a todos os seus integrantes para que não venham a sofrer nenhuma
} 
enseja a divisão de tarefas no âmbito da organização, ou seja, a distribuição de funções ou papéis entre os componentes e, por conseguinte, a existência de hierarquia, ainda que rudimentar ou informal, com vocação para a permanência. Ao criar uma espécie de pirâmide, a organização criminosa proporciona o aparecimento de um órgão autônomo localizado no vértice de sua estrutura, cuja função é tomar as decisões mais importantes para a vida da agremiação ${ }^{382}$.

2. Finalidade de lucro: consoante assentando anteriormente, contrariando a tendência mundial, a Lei n. ${ }^{\circ}$ 12.850/2013 conceituou organização criminosa ao largo de qualquer finalidade econômica. Dispensou-se, portanto, ao menos diretamente ${ }^{383}$, a

desigualdade ou injustiça em conflitos externos; 07 - Aquele que estiver em liberdade, 'bem estruturado', mas esquecer de contribuir com os irmãos que estão na cadeia, será condenado à morte, sem perdão; 08 Os integrantes do Partido têm que dar bom exemplo a ser seguido e por isso o Partido não admite que haja: assalto, estupro e extorsão dentro do sistema; 09 - O Partido não admite mentiras, traição, inveja, cobiça, calúnia, egoísmo, interesse pessoal, mas sim, a verdade, a fidelidade, a hombridade, solidariedade ao interesse comum ao bem de todos, porque somos um por todos e todos por um; 10 - Todo integrante terá que respeitar a ordem e a disciplina do Partido. Cada um vai receber de acordo com aquilo que fez por merecer. A opinião de todos será ouvida e respeitada, mas a decisão final será dos fundadores do Partido; 11 - O Primeiro Comando da Capital - P.C.C., fundado no ano de 1993, numa luta descomunal e incansável contra a opressão e as injustiças do Campo de Concentração 'ANEXO' da Casa de Custódia de Taubaté, tem como lema absoluto 'A Liberdade, a Justiça e a Paz'; 12 - O Partido não admite rivalidades internas, disputas do poder na liderança do Comando, pois cada integrante do Comando sabe a função que lhe compete de acordo com sua capacidade para exercê-la; 13 - Temos que permanecer unidos e organizados para evitarmos que ocorra novamente um massacre semelhante ou pior ao ocorrido na Cada de Detenção em 2 de outubro de 1992, quando 111 presos foram covardemente assassinados, massacre este que jamais será esquecido na consciência da sociedade brasileira. Porque nós do Comando vamos sacudir o sistema e fazer essas autoridades mudarem a prática carcerária desumana, cheia de injustiça, opressão, torturas, massacres nas prisões; 14 - A prioridade do Comando no momento é pressionar o Governo do Estado a desativar aquele Campo de Concentração 'ANEXO' à Casa de Custódia e Tratamento de Taubaté de onde surgiram a semente e as raízes do Comando, no meio de tantas lutas inglórias e tantos sofrimentos atrozes; 15 - Partindo do Comando Central da Capital, o QG do Estado, as diretrizes de ações organizadas e simultâneas em todos os Estabelecimentos Penais do Estado numa guerra sem tréguas, sem fronteiras, até a vitória final; 16 - O importante de tudo é que ninguém nos deterá nessa luta porque a semente do Comando se espalhou em todo o Sistema Penitenciário do Estado e conseguimos nos estruturar também do lado de fora, com muitos sacrifícios e perdas, mas nos consolidamos a nível estadual e a longo prazo nos consolidaremos também a nível nacional. Conhecemos nossa força e a força de nossos inimigos poderosos, mas estamos preparados, unidos, e um povo unido jamais será vencido" (SOUZA, Fátima. PCC: a facção. Rio de Janeiro: Record, 2007. p. 11-13).

${ }^{382}$ PELLEGRINI, Angiolo; COSTA JR., Paulo José da. Criminalidade organizada, cit., p. 13. Ainda a propósito da hierarquia, a Lei n. ${ }^{\circ} 12.850 / 2013$, no artigo $2^{\circ}, \S 3^{\circ}$, considerou circunstância de maior punibilidade a conduta do agente que exerce o comando, individual ou coletivo, da organização criminosa, ainda que não pratique pessoalmente atos de execução.

${ }^{383}$ Vicente Greco Filho assinala, com precisão, que a vantagem exigida pela Lei n. ${ }^{\circ}$ 12.850/2013 "é qualquer benefício, inclusive a simples manutenção de uma estrutura de poder ou poderio. É certo que, no fundo, poderá haverá (sic) um interesse econômico, como o de uma organização criminosa para, por meio da força, manter um oligopólio de atividade econômica lícita. A vantagem, no caso, somente de maneira indireta é econômica, mas é suficiente para caracterizar a ilicitude da organização em virtude do uso da força para a manutenção ilegal de uma atividade se analisada isoladamente pode ser legítima. A vantagem 
finalidade de lucro na configuração do plano deliquencial, que, como visto, exsurge tão caro à conjuntura internacional. Em termos práticos, portanto, pela redação do artigo $1^{\circ}, \S$ $1^{\circ}$, da Lei de Organizações Criminosas, qualquer vantagem, com conteúdo econômico ou não, pode gerar o crime previsto no artigo $2^{\circ}$, punido com reclusão de 3 (três) a 8 (oito) anos, e multa, sem prejuízo das penas correspondentes às demais infrações praticadas. Pode ser vantagem moral, sentimental, espiritual, ou mesmo sexual, como, aliás, sucede, verbi gratia, com o crime de corrupção passiva, que se vale do termo, de resto mais restritivo, "vantagem indevida" 384 . Concretamente: é possível cogitar uma organização criminosa voltada à prática do crime de pedofilia, estampado no artigo 241-A da Lei n. ${ }^{\circ}$ 8.069/1990 (Estatuto da Criança e do Adolescente), pois a pedofilia, que não tem natureza econômica, é punida com pena máxima superior a 4 (quatro) anos, no caso 6 (seis) anos de reclusão, além de multa.

3. Prática de crimes graves: o legislador brasileiro condicionou a configuração típica da organização criminosa à caracterização de um critério objetivo relacionado à quantidade da pena cominada ao crime-fim (infrações penais cujas penas máximas sejam superiores a quatro anos) e à qualidade da infração (caráter transnacional $)^{385}$, seguindo, ao menor parcialmente, a Convenção de Palermo, haja vista que esta considera infração penal grave aquela cujo máximo não seja inferior a quatro anos. Outro caminho possível seria catalogar em um rol cerrado (numerus clausus) as infrações penais que gerariam a organização criminosa, tal como sucedeu originariamente na Lei de "Lavagem" de Dinheiro. Essa solução, segundo Laura Zúñiga, afigurar-se-ia mais consentânea ao princípio da taxatividade ${ }^{386}$. De todo modo, ao eleger apenas esses dois critérios para configuração do crime-fim (quantidade da pena e transnacionalidade), Lei n. $^{\circ}$ 12.850/2013 renunciou à ideia de violência na formulação do conceito de

pode ser, até, de natureza política, ou seja, o acesso só poder político legítimo e sua manutenção para a prática de crimes" (GRECO FILHO, Vicente. Comentários à lei de organização criminosa: Lei n. ${ }^{\circ}$ 12.850/13, São Paulo: Saraiva, 2014. p. 22).

${ }^{384}$ Nesse sentido: BITENCOURT, Cezar Roberto. Tratado de direito penal: parte especial, dos crimes contra a administração pública e dos crimes praticados por prefeitos. 6. ed. São Paulo: Saraiva, 2012. v. 5, p. 118; PAGLIARO, Antonio; COSTA JR., Paulo José da. Dos crimes contra a administração pública, cit., p. 110.

${ }^{385} \mathrm{O}$ expediente adotado pelo legislador impede, a nosso ver, a vulgarização de um delito extremamente grave e evita discussões relacionadas à violação do princípio da proporcionalidade ou da razoabilidade.

${ }^{386}$ ZÚÑIGA RODRÍGUEZ Laura. Criminalidad organizada y sistema de derecho penal: contribución a la determinación del injusto penal de organización criminal, cit., p. 273. 
organização criminosa, elemento que tradicionalmente tem sido mencionado como integrante de sua natureza sociológica ${ }^{387}$.

4. Busca pela impunidade: ao montar uma estrutura permanente e estável destinada à prática de crimes graves, a organização criminosa estabelece, em paralelo, uma série de procedimentos hábeis à ocultação de sua atividade criminosa. Sob esse contexto emerge a relevância da "lavagem" de capitais para atribuir aos recursos financeiros obtidos criminosamente uma aparência de legalidade ${ }^{388}$. As organizações mais sofisticadas preferem, em regra, mascarar seus recursos ilícitos em localidades diversas daquelas onde foi levado a efeito o crime antecedente, isto é, de onde proveio o "dinheiro sujo"; daí a utilização de "paraísos fiscais", denominados oficialmente de "países ou dependências com tributação favorecida" ${ }^{389}$, e o consequente aparecimento de uma criminalidade cujos efeitos não ficam restritos ao território de um determinado país, revelando-se, pois, transnacional ${ }^{390}$.

5. Secretismo: a organização criminosa desenvolve suas atividades em segredo, de modo oculto, em ordem a não chamar a atenção das autoridades investidas da persecutio criminis. $\mathrm{O}$ secretismo normalmente vem associado às organizações criminosas de configuração mafiosa em virtude do instituto da omertà, ou seja, do pacto de silêncio

\footnotetext{
${ }^{387}$ Nesse sentido, observa Guaracy Mingardi que por "crime organizado tradicional" se compreende o "Grupo de pessoas voltadas para atividades ilícitas e clandestinas que possui uma hierarquia própria e capaz de planejamento empresarial, que compreende a divisão do trabalho e o planejamento de lucros. Suas atividades se baseiam no uso da violência e da intimidação, tendo como fonte de lucros a venda de mercadorias ou serviços ilícitos, no que é protegido por setores do Estado. Tem como características distintas de qualquer outro grupo criminoso um sistema de clientela, a imposição da lei do silêncio aos membros ou pessoas próximas e o controle pela força de determinada porção de território" (MINGARDI, Guaracy. O Estado e o crime organizado. São Paulo: IBBCRIM, 1998. p. 82-83). A Lei n. ${ }^{\circ} 12.850 / 2013$ apenas considerou uma circunstância de maior punibilidade (aumenta-se a pena até a metade) o fato de na atuação da organização criminosa existir o emprego de arma de fogo (cf. art. $2^{\circ}, \S 2^{\circ}$ ).

${ }^{388}$ Consoante põem em destaque Angiolo Pellegrini e Paulo José da Costa Jr., o "anel de ligação entre economia legal e ilegal é constituído pelos intermediários financeiros, aos quais é atribuída a tarefa de reciclar os patrimônios, dando a eles um crisma de legalidade através de um número tal de transações que cancele os traços de sua proveniência, garantindo aos capitais repolidos elevada taxa de liquidez" (PELLEGRINI, Angiolo; COSTA JR., Paulo José da. Criminalidade organizada, cit., p. 15). Nesse mesmo sentido: MAIA, Rodolfo Tigre. Lavagem de dinheiro (lavagem de ativos provenientes de crime): anotações às disposições criminais da Lei n. 9.613/98. 1. ed., 2.tir. São Paulo: Malheiros Ed., 2009. p. 12-13.

${ }^{389}$ Os países ou dependências com tributação favorecida encontram disciplina no artigo 24 , § $4^{\circ}$, da Lei n..$^{\circ}$ 9.430/1996: considera-se também país ou dependência com tributação favorecida aquele cuja legislação não permita o acesso a informações relativas à composição societária de pessoas jurídicas, à sua titularidade ou à identificação do beneficiário efetivo de rendimentos atribuídos a não residentes.

${ }^{390}$ BLANCO CORDERO, Isidoro. El delito de blanqueo de capitales. 3. ed. Navarra: Editorial Aranzadi, 2012. p. 54-55.
} 
decorrente do inerente poder de intimidação da estrutura criminosa, que redunda na completa ausência de colaboração com os órgãos estatais para o descobrimento de crimes $^{391}$. A divisão da organização em compartimentos (compartimentalização) autônomos também representa um fator que contribui sensivelmente para a preservação da clandestinidade, uma vez que os autores imediatos de condutas criminosas não recebem ordens diretas dos seus líderes, evitando, com isso, que possa haver o reconhecimento dos agentes que ocupam o comando ${ }^{392}$.

6. Vinculações com mundo empresarial: as organizações criminosas se conformam estruturalmente através de hierarquia e da divisão de tarefas, à semelhança das sociedades empresárias; nessa condição, se utilizam do sistema financeiro nacional e internacional para a ocultação de seus proventos e para a maximização do lucro criminoso. Demais disso, instrumentalizam as pessoas jurídicas regularmente constituídas (instituições financeiras, por exemplo), para misturar recursos lícitos e ilícitos ${ }^{393}$.

7. Vinculações com o mundo político: a perpetuação da organização criminosa no tempo reclama a proteção das instituições públicas, dos órgãos do Estado formalmente constituídos, aí incluídos o Poder Executivo, o Poder Legislativo, o Poder Judiciário e o Ministério Público. Sob esse contexto, agentes políticos e funcionários públicos são corrompidos para proporcionar imunidade persecutória ao aparato criminoso, encobrindo atos criminosos e garantindo o lucro ilícito ${ }^{394}$.

\footnotetext{
${ }^{391}$ Explica Giuseppe Spagnolo que outrora a omertà tinha significado positivo, visto que ligada à ideia de um código social dos homens de verdade, de honra, os quais acreditavam na lei da própria consciência. O silêncio, neste caso, derivava do confronto com um Estado opressor e injusto. O Código Penal Italiano, porém, atribui-lhe, no artigo 416 bis, conotação diversa, de conteúdo negativo, de falta de cooperação com os órgãos públicos devido ao medo que prevalece sobre o sentimento de solidariedade social (SPAGNOLO, Giuseppe. L'associazione di tipo mafioso. 5. ed. agg. Padova: Cedam, 1997. p. 38).

${ }^{392}$ BALTAZAR JUNIOR, José Paulo. Crime organizado e proibição de insuficiência, cit., p. 130.

${ }^{393}$ Como anota Laura Zúñiga Rodríguez, os vínculos existentes entre as organizações criminosas e as empresas legalmente constituídas são cada vez mais evidentes, pois existem necessidades mútuas dentro do círculo produtivo: a prática de crimes, a ocultação de crimes e o financiamento para a perpetração de outros delitos. ZÚÑIGA RODRÍGUEZ Laura. Criminalidad organizada y sistema de derecho penal: contribución a la determinación del injusto penal de organización criminal, cit., p. 144.

${ }^{394}$ BALTAZAR JUNIOR, José Paulo. Crime organizado e proibição de insuficiência, cit., p. 131; ZÚÑ̃IGA RODRÍGUEZ Laura. Criminalidad organizada y sistema de derecho penal: contribución a la determinación del injusto penal de organización criminal, cit., p. 146. Observa Raimondo Catanzaro, a propósito, que o estreito relacionamento entre a máfia e o mundo político faz com que a população veja os mafiosos como legítimos representantes da sociedade e guardiões da ordem (CATANZARO, Raimondo. El delito como empresa: história social de la máfia. Madrid: Taurus Humanidades, 1992. p. 162). Para
} 
8. Busca pelo domínio do mercado: este elemento contingencial tem sido atribuído somente às organizações mais sofisticadas, complexas, que visam expansão e, portanto, a conquista de determinado segmento representa uma etapa natural ${ }^{395}$. De fato, algumas organizações, como as italianas, colocam-se em uma posição de superioridade em relação a outras associações com menos desenvoltura e capilaridade, mas que constituem "o reservatório de mão-de-obra, do qual se seleciona o futuro quadro diretor da própria família"396.

9. Transnacionalidade: nem toda a organização criminosa é transnacional, ou seja, irradia seus deletérios efeitos para além das fronteiras nacionais; daí a consideração desse elemento no plano secundário. Não obstante, como apontamos alhures, pelo menos nas organizações mais sofisticadas existe uma tendência à transnacionalidade (ou internacionalidade) ${ }^{397}$, pois a utilização de ordenamentos jurídicos com conformações diferentes (common law e civil law) acarreta enormes dificuldades na implementação da persecução penal. Com efeito, no mais das vezes as autoridades que exercem atividade investigatória valer-se-ão de normas de cooperação internacional insuficientemente regulamentadas e de regras costumeiras que não são interpretadas com precisão no Direito positivo brasileiro ${ }^{398}$.

\footnotetext{
Guaracy Mingardi o crime organizado "não pode existir em larga escala se não tiver algum tipo de acordo, ou conluio, com setores do Estado Nacional (MINGARDI, Guaracy. O Estado e o crime organizado, cit., p. 18). Atenta a essa realidade, a Lei n. ${ }^{\circ} 12.850 / 2013$ pune com mais severidade a conduta (aumento de pena de 1/6 (um sexto) a 2/3 (dois terços)) quando houver o concurso de funcionário público, valendo-se a organização criminosa dessa condição para a prática de infração penal (art. $2^{\circ}, \S 4^{\circ}$, inciso II).

${ }^{395}$ ZÚÑIGA RODRÍGUEZ Laura. Criminalidad organizada y sistema de derecho penal: contribución a la determinación del injusto penal de organización criminal, cit., p. 148.

${ }^{396}$ PELLEGRINI, Angiolo; COSTA JR., Paulo José da. Criminalidade organizada, cit., p. 14.

${ }^{397}$ Daí o aumento da pena (de $1 / 6$ (um sexto) a $2 / 3$ (dois terços)) para o crime do artigo $2^{\circ}$ da Lei de Organizações Criminosas, se o produto ou proveito da infração penal destinar-se, no todo ou em parte, ao exterior, ou se as circunstâncias do fato evidenciarem a transnacionalidade da organização (art. $2^{\circ}, \S 4^{\circ}$, da Lei n. $\left.{ }^{\circ} 12.850 / 2013\right)$.

${ }^{398}$ Basta citar, por exemplo, que além de alguns Tratados e Convenções Internacionais, a regulamentação matriz em matéria de cooperação jurídica internacional em matéria penal encontra-se na Resolução n. ${ }^{\circ} 9$ do Superior Tribunal de Justiça.
} 


\subsection{Organizações criminosas e organizações empresariais}

\subsubsection{Considerações preliminares}

A dinâmica da criminalidade moderna tem aproximado a realidade das organizações criminosas, formadas à margem do ordenamento jurídico, às atividades desempenhadas pelas organizações empresariais, cuja essência consiste na produção de bens e serviços não proibidos por lei e na busca lícita de benefícios econômicos.

Os vínculos que unem os aparatos criminosos ao mundo empresarial são diversos e intensos, como anotamos anteriormente, e às vezes chegam a se confundir, especialmente nos crimes econômicos, porquanto cometidos, no mais das vezes, no âmbito das sociedades empresárias, por seus sócios, empregados ou prestadores de serviço, em benefício da própria empresa ou sob seu contexto ${ }^{399}$, de que são exemplos costumeiros os delitos contra a ordem tributária (Lei n. ${ }^{\circ}$ 8.137/1990), contra a ordem previdenciária (arts. 168-A e 337-A do Código Penal) e os delitos contra o sistema financeiro nacional (Lei n. ${ }^{\circ}$ $7.492 / 1986)$.

Com efeito, as organizações criminosas têm adotado modelos de estrutura e de gestão similares às grandes empresas visando a maximização do lucro. Nos moldes das sociedades regularmente constituídas, as organizações criminosas têm utilizado o componente associativo-empresarial para produzir, distribuir e comercializar seus produtos lícitos e ilícitos acabando por intervir no mundo econômico ${ }^{400}$.

Essa intervenção enseja, como revela José Paulo Baltazar Júnior, uma concorrência desleal $^{401}$ com as empresas que atuam licitamente no mercado e transmite

\footnotetext{
${ }^{399}$ ESTELLITA, Heloisa Criminalidade de empresa, quadrilha, e organização criminosa, cit., p. 29.

${ }^{400}$ ZÚÑIGA RODRÍGUEZ Laura. Bases para un modelo de imputación de responsabilidad penal a las personas jurídicas, cit., p. 108; PITOMBO, Antônio Sérgio Altieri de Moraes. Organização criminosa, nova perspectiva do tipo legal, cit., p. 129-130. No mesmo sentido, aponta Guaracy Mingardi que a característica mais marcante do modelo empresarial de organização criminosa "é transpor para o crime métodos empresariais, ao mesmo tempo que deixam de lado qualquer resquício de conceitos como Honra, Lealdade, Obrigação, etc." (MINGARDI, Guaracy. O Estado e o crime organizado, cit., p. 88).

${ }^{401}$ BALTAZAR JUNIOR, José Paulo. Crime organizado e proibição de insuficiência, cit., p. 112.
} 
uma mensagem extremamente danosa para a economia, haja vista que o empresário regular, que atua em conformidade com regras jurídicas, ver-se-á compelido a aderir à atividade delituosa.

A despeito dessa notável aproximação, existem critérios distintivos que podem ser extraídos do cotejo entre as organizações empresariais e as organizações criminosas. A verificação desses critérios impede que a mera constituição de uma sociedade empresária seja equiparada à fundação de uma organização criminosa e, ao mesmo tempo, obsta a imputação penal automática com a respectiva incidência de um conjunto normativo marcado pela cominação de penas severas e pela utilização de técnicas especiais de investigação ${ }^{402}$.

Deveras, como destaca Heloisa Estellita em comentário relativo ao crime de quadrilha ou bando, mas aplicável perfeitamente à hipótese sob análise pela identidade de fundamentos, "não é admissível que toda imputação da prática de crime econômico contra quatro pessoas ou mais, atuando em contexto de sociedade empresarial (sócios, gerentes, diretores, funcionários etc.), venha acompanhada, ipso facto, da imputação do crime de quadrilha ou bando. A confusão entre a reunião de pessoas para a prática de atos lícitos com o crime descrito no artigo 288 do Código Penal subverte a ordem jurídica, que, como se viu, expressamente autoriza a reunião de pessoas para o exercício de atividade empresarial” ${ }^{, 403}$.

\subsubsection{Elementos comuns}

Os elementos identificadores das organizações criminosas que também podem ser encontrados nas organizações empresariais são a (i) pluralidade de pessoas; a

\footnotetext{
${ }^{402}$ Regulamentadas atualmente no artigo $3^{\circ}$ da Lei n. ${ }^{\circ}$ 12.850/2013: Em qualquer fase da persecução penal, serão permitidos, sem prejuízo de outros já previstos em lei, os seguintes meios de obtenção da prova: Icolaboração premiada; II - captação ambiental de sinais eletromagnéticos, ópticos ou acústicos; III - ação controlada; IV - acesso a registros de ligações telefônicas e telemáticas, a dados cadastrais constantes de bancos de dados públicos ou privados e a informações eleitorais ou comerciais; V - interceptação de comunicações telefônicas e telemáticas, nos termos da legislação específica; VI - afastamento dos sigilos financeiro, bancário e fiscal, nos termos da legislação específica; VII - infiltração, por policiais, em atividade de investigação, na forma do art. 11; VIII - cooperação entre instituições e órgãos federais, distritais, estaduais e municipais na busca de provas e informações de interesse da investigação ou da instrução criminal.

${ }^{403}$ ESTELLITA, Heloisa Criminalidade de empresa, quadrilha, e organização criminosa, cit., p. 30.
} 
(ii) divisão de tarefas ou funções; a (iii) hierarquia; a (iv) finalidade de lucro; (v) a intenção ou a vontade de ser membro de um grupo (affectio societatis); e a (vi) transnacionalidade.

1. Pluralidade de pessoas: consoante assentado alhures, o artigo $1^{\circ}, \S 1^{\circ}$, da Lei n. ${ }^{\circ} 12.850 / 2013$ exige pelo menos quatro pessoas para a caracterização da organização criminosa. O que mesmo sucede com as organizações empresariais: à exceção da empresa individual de responsabilidade limitada $^{404}$ e da subsidiária integral ${ }^{405}$, a pluralidade de indivíduos consubstancia um pressuposto da sua conformação jurídica ${ }^{406}$.

2. Divisão de tarefas ou funções: também pode ser compreendido como um elemento presente tanto nas organizações empresariais como nas organizações criminosas a repartição de atividades no interior da organização. A atribuição de tarefas confere uma estrutura organizacional que gera uma delimitação no entorno de obediência e também no entorno decisões do grupo ${ }^{407}$. Demais disso a atribuição de papéis especializa e profissionaliza as atividades da organização, valorizando os conhecimentos específicos de cada membro para alcançar os resultados almejados pelo grupo.

\section{Hierarquia: uma organização estruturada normalmente apresenta níveis} de hierarquia, de cadeias de comando estipuladas em conformidade com as tarefas que foram atribuídas aos seus componentes. As organizações empresariais complexas ${ }^{408}$ são altamente hierarquizadas, com diversos níveis intermediários. Para estas, mais sofisticadas, diz-se que são verticalizadas; para as organizações mais simples, com poucos patamares

\footnotetext{
${ }^{404}$ Art. 980-A do Código Civil: A empresa individual de responsabilidade limitada será constituída por uma única pessoa titular da totalidade do capital social, devidamente integralizado, que não será inferior a 100 (cem) vezes o maior salário-mínimo vigente no País.

${ }^{405}$ Art. 251 da Lei n. ${ }^{\circ}$ 6.404/1976: A companhia pode ser constituída, mediante escritura pública, tendo como único acionista sociedade brasileira.

${ }^{406}$ Art. 981 do Código Civil: Celebram contrato de sociedade as pessoas que reciprocamente se obrigam a contribuir, com bens ou serviços, para o exercício de atividade econômica e a partilha, entre si, dos resultados. E mais: Art. 1.033 do Código Civil. Dissolve-se a sociedade quando ocorrer: (...) IV - a falta de pluralidade de sócios, não reconstituída no prazo de cento e oitenta dias.

${ }^{407}$ DIAS, Reinaldo. Sociologia das organizações, cit., p. 148.

${ }^{408} \mathrm{Em}$ conformidade com Reinaldo Dias, a "complexidade constitui o grau em que as diferentes atividades da organização são decompostas nos plano horizontal, vertical ou espacial. No plano horizontal, quanto maior o número de atividades diferentes que exigem conhecimentos e habilidades especiais, mais complexa é a organização, surgindo dificuldades de comunicação e de coordenação dessas atividades. O plano vertical é onde se visualiza o grau de profundidade da hierarquia na organização. Quando mais níveis existirem entre a alta direção e o quadro operacional, maior será a complexidade da organização, o que implicará em maior possibilidade de surgimento de deficiências e problemas. Quanto ao plano espacial, diz respeito ao grau de dispersão geográfica; quanto maior a complexidade haverá mais problemas para a coordenação e o controle, e em menor grau de comunicação" (Id. Ibid., p. 159).
} 
hierárquicos, fala-se em horizontalização ${ }^{409}$. Não obstante essa divisão, Manuel Castells observa que, atualmente, existe uma tendência para que, ainda que complexas, as empresas alterem seu modelo organizacional vertical para "adaptar-se às condições de imprevisibilidade introduzidas pela rápida transformação econômica e tecnológica" ${ }^{\text {"10 }}$ e, assim, passem a ser horizontais. Nesse contexto, a empresa horizontal apresentaria sete tendências principais, segundo Castells: “organização em torno do processo, não da tarefa; hierarquia horizontal; gerenciamento em equipe; medida do desempenho pela satisfação do cliente; recompensa com base no desempenho da equipe; maximização dos contatos com fornecedores e clientes; informação, treinamento e retreinamento de funcionários em todos os níveis" ${ }^{\text {411. }}$.

É certo que essas tendências não podem ser transportadas sem maior temperamento às organizações criminosas, mas não parece menos correto reconhecer que algumas delas podem, sim, balizar as atividades de um aparato criminoso mais sofisticado voltado, por exemplo, ao tráfico internacional de substâncias entorpecentes ou à reciclagem de valores, ou a ambos, como acontece com as máfias italianas ${ }^{412}$.

4. Finalidade de lucro: a empresa ${ }^{413}$ é, por excelência, uma maximizadora do lucro, ou seja, sua existência encontra justificativa na obtenção de ganhos econômicos ${ }^{414}$. Essa afirmação encontra amparo no artigo 966 do Código Civil brasileiro, que considera empresário "quem exerce profissionalmente atividade econômica organizada para a produção ou a circulação de bens ou de serviços". O Código também estabelece, no artigo 982, que "considera-se empresária a sociedade que tem por objeto o exercício de atividade própria de empresário". A busca pelo lucro consubstancia, também, um elemento

\footnotetext{
${ }^{409}$ DIAS, Reinaldo. Sociologia das organizações, cit., p. 150.

${ }^{410}$ CASTELLS, Manuel. A sociedade em rede: a era da informação: economia, sociedade e cultura, cit., v. 1 , p. 221.

${ }^{411}$ Id. Ibid.

${ }^{412}$ Como põe em relevo Raimondo Catanzaro, a empresa moderna é uma estrutura organizativa extraordinariamente complexa e, no caso das empresas mafiosas, essa complexidade organizativa não pode ser encontrada em cada empresa considerada isoladamente, mas na rede de empresas que pertencem a uma mesma família (CATANZARO, Raimondo. El delito como empresa: história social de la máfia, cit., p. 295).

${ }^{413}$ Costuma-se diferenciar, no Direito Comercial, a empresa da sociedade empresária. A empresa constitui uma abstração, o exercício da atividade produtiva. A sociedade empresária, de outro lado, é o sujeito do qual a empresa é o objeto (Nesse diapasão: REQUIÃO, Rubens. Curso de direito comercial. 22. ed. São Paulo: Saraiva, 1995. v. 1, p. 56-58).

${ }^{414}$ ROSSETTI, José Paschoal; ANDRADE, Adriana. Governança corporativa: fundamentos, desenvolvimento e tendências. 6. ed. São Paulo: Atlas, 2012. p. 76.
} 
comum na definição das organizações criminosas $^{415}$, embora dessa realidade tenha se afastado o ordenamento brasileiro ao editar a Lei n. ${ }^{\circ} 12.850 / 2013$, conforme aduzido alhures $^{416}$.

5. Intenção ou a vontade de ser membro de um grupo: tanto na sociedade empresária como na organização criminosa os sujeitos devem estar imbuídos do espírito de grupo, isto é, devem possuir a consciência de que são peças componentes de uma estrutura adrede destinada à concretização de uma finalidade que beneficie a todos. Trata-se, evidentemente, de um elemento de natureza subjetiva: no marco das organizações empresariais fala-se em affectio societatis ${ }^{417}$, enquanto que para as organizações criminosas menciona-se o dolo, isto é, a vontade livre e consciente de praticar a conduta delituosa concretizando todos os elementos dispostos no artigo $2^{\circ}$ da Lei ${ }^{\circ}{ }^{\circ} 12.850 / 2013$, com a ressalva de que na conduta de integrar organização criminosa o agente deve ter conhecimento (direto ou indireto) de que compõe efetivamente a organização, de que nela intervém relevantemente de modo estável e permanente ou, como prefere Laura Zúñiga, de que "constituem parte de uma estrutura delitiva institucionalizada" 418.

6. Transnacionalidade: outro ponto de contato entre as empresas empresariais e as organizações criminosas deriva da eventual internacionalidade de suas atividades, da importação e exportação de produtos e da utilização do sistema financeiro global.

\footnotetext{
${ }^{415} \mathrm{O}$ Código Penal Italiano chega, inclusive, a elevar a busca pelo lucro à condição de elemento subjetivo específico do crime de associação de tipo mafioso, previsto no artigo 416-bis: "L'associazione è di tipo mafioso quando coloro che ne fanno parte si avvalgano della forza di intimidazione del vincolo associativo e della condizione di assoggettamento e di omertà che ne deriva per commettere delitti, per acquisire in modo diretto o indiretto la gestione o comunque il controllo di attività economiche, di concessioni, di autorizzazioni, appalti e servizi pubblici o per realizzare profitti o vantaggi ingiusti per sé o per altri, ovvero al fine di impedire od ostacolare il libero esercizio del voto o di procurare voti a sé o ad altri in occasione di consultazioni elettorali".

${ }^{416}$ Não obstante a internalização da Convenção de Palermo pelo Decreto n. ${ }^{\circ}$ 5015/2004, cujo artigo $2^{\circ}$ exige, para a configuração do grupo criminoso organizado, a intenção de obter, direta ou indiretamente, um benefício econômico ou outro benefício material.

${ }^{417}$ REQUIÃO, Rubens. Curso de direito comercial, cit., v. 1, p. 288-289.

${ }^{418}$ ZÚÑIIGA RODRÍGUEZ Laura. Criminalidad organizada y sistema de derecho penal: contribución a la determinación del injusto penal de organización criminal, cit., p. 278.
} 


\subsubsection{Elementos distintivos}

Sob outro giro, decompondo os requisitos constitutivos das organizações criminosas delineados no artigo $1^{\circ}, \S 1^{\circ}$, da Lei n. ${ }^{\circ} 12.850 / 2013$, e comparando-os com os requisitos das organizações empresariais, é possível chegar ao seguinte grupo de elementos distintivos: (i) prática de atividades ilícitas; (ii) busca pela impunidade; (iii) clandestinidade; (iv) métodos adotados no desempenho das atividades. Passemos ao exame desses aspectos.

1. Prática de atividades ilícitas: a organização empresarial (sociedade empresária) é um instituto genuinamente jurídico não somente porque a sua atividade irradia efeitos jurídicos, mas principalmente porque ela só existe juridicamente, vale dizer, porque o ordenamento brasileiro lhe conforme personalidade jurídica, o que sucede com a inscrição, no registro próprio e na forma da lei, dos seus atos constitutivos ${ }^{419}$. A partir desse momento, a sociedade empresária conforma-se juridicamente, transformando-se em sujeito capaz de direitos e de obrigações, podendo, em nome próprio, contratar, se obrigar, apresentar-se em juízo ${ }^{420}$ e gerir seu próprio patrimônio, o qual não se confunde com o de seus sócios $^{421}$. Nesse sentido, pode-se asseverar que a empresa está juridicamente vocacionada para a obtenção de benefícios lícitos, legais, enquanto que as organizações criminosas visam angariar bens mediante a prática de atividades proibidas pelo ordenamento jurídico (crimes-fim) ${ }^{422}$. Com efeito, as organizações empresariais produzem bens e proporcionam serviços de consumo e de uso regular na sociedade; as organizações criminosas, ao revés, se estruturam com o desiderato de cometer crimes e, por intermédio deles, angariar recursos financeiros.

\footnotetext{
${ }^{419}$ Artigo 985 do Código Civil.

${ }^{420}$ Art. 1.022 do Código Civil: A sociedade adquire direitos, assume obrigações e procede judicialmente, por meio de administradores com poderes especiais, ou, não os havendo, por intermédio de qualquer administrador

${ }^{421}$ Art. 1.023 do Código Civil. Se os bens da sociedade não lhe cobrirem as dívidas, respondem os sócios pelo saldo, na proporção em que participem das perdas sociais, salvo cláusula de responsabilidade solidária. Art. 1.024 do Código Civil. Os bens particulares dos sócios não podem ser executados por dívidas da sociedade, senão depois de executados os bens sociais.

${ }^{422}$ ZÚÑIGA RODRÍGUEZ Laura. Criminalidad organizada y sistema de derecho penal: contribución a la determinación del injusto penal de organización criminal, cit., p. 137.
} 
2. Busca pela impunidade: tendo presente que as organizações empresariais desenvolvem-se em conformidade com o ordenamento jurídico, não há razão de qualquer natureza dela desenvolver métodos tendentes à ocultação de sua atividade econômica.

3. Clandestinidade: por empreender atividade lícita, a organização empresarial não precisa se esconder; ao contrário, o registro dos seus atos constitutivos e demais atos societários na Junta Comercial surge como condição indeclinável no mundo das sociedades empresárias ${ }^{423}$. Ademais, atrelando sua primordial função social à obtenção do lucro e à movimentação da economia, faz-se imperiosa a ampla divulgação dos produtos e das atividades realizadas pelo ente empresarial.

4. Métodos adotados no desempenho das atividades: em conjunto com a natureza (lícita ou ilícita) das atividades, o elemento que mais frequentemente tem sido citado pela doutrina para distinguir as organizações criminosas das empresas diz respeito aos métodos empregados na consecução dos fins almejados ${ }^{424}$. Assim, costuma-se afirmar que a organização empresarial utilizar-se-á, no exercício de suas operações, de métodos juridicamente aceitos, formalmente pacíficos, enquanto que as organizações criminosas valer-se-ão de expedientes violentos, da intimidação e da imposição da lei do silêncio $(\text { omertà })^{425}$. Analisando esses fatores de discriminação sob a perspectiva das organizações criminosas italianas, Raimondo Catanzaro vislumbra quatro espécies de empresas, sendo certo que as três primeiras podem ser consideradas empresas mafiosas: "1. empresas que desempenham atividades de produção ilícitas e utilizam métodos violentos para inibir a concorrência; 2. empresas que desempenham atividades de produção ilícitas e utilizam métodos formalmente pacíficos (tipo nada fácil de encontrar na prática); 3. empresas que desempenham atividades de produção lícitas e utilizam métodos violentos para inibir a concorrência; 4. empresas que desempenham atividades de produção lícitas e utilizam

\footnotetext{
${ }^{423}$ Art. 1.150 do Código Civil: O empresário e a sociedade empresária vinculam-se ao Registro Público de Empresas Mercantis a cargo das Juntas Comerciais, e a sociedade simples ao Registro Civil das Pessoas Jurídicas, o qual deverá obedecer às normas fixadas para aquele registro, se a sociedade simples adotar um dos tipos de sociedade empresária. Art. 1.151 do Código Civil: $\mathrm{O}$ registro dos atos sujeitos à formalidade exigida no artigo antecedente será requerido pela pessoa obrigada em lei, e, no caso de omissão ou demora, pelo sócio ou qualquer interessado.

${ }^{424}$ BALTAZAR JUNIOR, José Paulo. Crime organizado e proibição de insuficiência, cit., p. 110; MINGARDI, Guaracy. O Estado e o crime organizado, cit., p. 83.

${ }^{425}$ CATANZARO, Raimondo. El delito como empresa: história social de la máfia, cit., p. 293.
} 
métodos formalmente pacíficos" ${ }^{\text {426 }}$.

O critério utilizado por Catanzaro tem o mérito de inserir um elemento objetivo (violência) na elaboração da distinção entre as várias empresas e, dessa forma, evitar a conclusão de que toda a sociedade empresária que tomar parte em algum evento delituoso passa a ser automaticamente considerada mafiosa, mas é necessário reconhecer que ele foi concebido com os olhos direcionados ao contexto (social e jurídico) italiano, uma vez que o delito de associação de tipo italiano, previsto no artigo 416-bis do Código Penal, exige que os agentes se valham da força de intimidação que emerge do vínculo associativo $^{427}$.

No Brasil, consoante mencionado anteriormente, o caso é diverso e substancialmente mais complexo, pois o delito de organização criminosa, delineado no artigo $2^{\circ}$ da Lei n. ${ }^{\circ} 12.850$, prescinde do uso da força e do manejo de recursos intimidatórios para a sua configuração jurídico-penal. Essa situação não causa maiores problemas para as empresas que são criadas com o escopo específico de praticar crimes

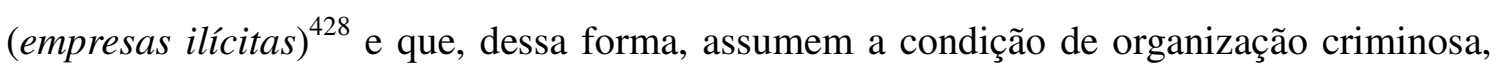
mas representa terreno manifestamente fértil à controvérsia em relação às organizações e sociedades empresárias lícitas, que ostentam pontos de contato com as organizações criminosas (pluralidade de pessoas, divisão de tarefas, hierarquia, finalidade de lucro e

\footnotetext{
${ }^{426}$ CATANZARO, Raimondo. El delito como empresa: história social de la máfia, cit., p. 293.

${ }^{427}$ Raimondo Catanzaro frequentemente associa a atividade empresarial desenvolvida pela Máfia à violência e à utilização de expedientes intimidatórios: "O que caracteriza o sistema da economia mafiosa e a relação entre empresas e indivíduos dentro do sistema e com a economia em seu conjunto é uma maior concorrência; mas a arma fundamental dessa concorrência será representada pela violência. A forma empresarial é, para os grupos mafiosos, um instrumento para a consecução de fins ilícitos e esses fins se perseguem mediante o recurso conjunto a transações de mercado e transações violentas; não se consegue eliminar a violência da economia; as relações de mercado no se desenvolvem de modo formalmente pacíficos, senão através de formas intimidatórias e métodos violentos" (Id. Ibid., p. 297).

${ }^{428}$ Cite-se o caso concreto do BCCI (Bank of Credit Commerce International), fundado em 1972 pelo investidor paquistanês Agha Hasan Abedi e que foi sediado em Luxemburgo. O banco foi à quebra em 1991 após uma profunda investigação realizada por agentes ingleses e norte-americanos que constatou que a instituição dedicava-se à lavagem de recursos provenientes dos cartéis de drogas colombianos e de recursos públicos desviados criminosamente pelo General panamenho Manuel Antonio Alberto Noriega e outros ditadores, como Samuel Doe (Libéria) e Joseph Désiré Mobutu (Zaire) (ZIEGLER, Jean. Os senhores do crime: as novas máfias contra a democracia. Rio de Janeiro: Record, 2003. p. 213-227). É recorrente a afirmação de que o BCCI foi concebido desde o início com o propósito de "lavar" dinheiro (MINGARDI, Guaracy. O Estado e o crime organizado, cit., p. 190) e que ele, a parte da estrutura formal, pública, criou um "banco dentro do banco" com rígida estrutura hierárquica e compartimentalizada,
} 
affectio societatis) e que eventualmente tangenciam a atividade delituosa ${ }^{429}$, ou seja, em cujo contexto são praticados, por seus dirigentes, sócios, representantes legais e funcionários, crimes em benefício próprio, da empresa ou da organização ${ }^{430}$.

Para essas hipóteses, Heloisa Estellita e Luís Greco indicam o seguinte critério para distinguir organização empresária da organização criminosa: deve-se analisar a existência de um injusto autônomo (injusto da organização), que não se mistura, a toda evidência, com o objeto social da empresa. Esse particular injusto deriva do fato de a sociedade empresária apresentar uma orientação objetiva no sentido da prática de delitos $^{431}$, ou seja, que as condutas delitivas "sejam praticadas no seio da organização de modo automático, sem necessidade de um novo processo decisório: a decisão quanto ao 'se' da prática de delitos é tomada por cada membro no momento de entrar na organização" 432 .

Estellita e Luís Greco propõem, então, o seguinte e interessante raciocínio diferenciador, de notável utilidade prática: “o delito associativo só estará realizado se, subtraindo-se mentalmente a prática de quaisquer outros delitos, restar na mera associação de pessoas conteúdo de desvalor suficiente a ponto de justificar uma sanção penal. Se o único ponto de apoio para a imputação do delito associativo for a prática dos outros crimes, está-se punindo essa prática duas vezes, já que associação, em si mesma, é algo que o ordenamento jurídico não valora negativamente" ${ }^{\text {433 }}$.

\footnotetext{
${ }^{429}$ ESTELLITA, Heloisa; GRECO, Luís. Empresa, quadrilha (art. 288 do CP) e organização criminosa, uma sob a luz do bem jurídico tutelado. Revista Brasileira de Ciências Criminais, São Paulo, ano 19, v. 91, p. 397, jul./ago. 2011.

${ }^{430} \mathrm{Na}$ análise do crime de quadrilha no julgamento dos Embargos Infringentes da Ação Penal n. ${ }^{\circ} 470$ ("Caso Mensalão"), o Ministro Celso de Mello, do Supremo Tribunal Federal, referiu-se expressamente à possibilidade hipotética da incidência da Lei n. ${ }^{\circ}$ 12.850/2013 em razão da formação de uma verdadeira organização criminosa pelos réus. Sua Excelência, todavia, deixou de aplicar os dispositivos da Lei de Organizações Criminosas em homenagem ao princípio da irretroatividade da Lex gravior, uma vez que os fatos haviam sido praticados anteriormente à sua vigência.

${ }^{431}$ ESTELLITA, Heloisa; GRECO, Luís. Empresa, quadrilha (art. 288 do CP) e organização criminosa, uma sob a luz do bem jurídico tutelado, cit., p. 404.

${ }^{432}$ Id. Ibid., p. 406.

${ }^{433}$ Id. Ibid., p. 405.
} 


\subsubsection{Conclusão e tomada de postura}

1. Os diversos pontos de contato entre as organizações empresariais e as organizações criminosas constituem um fator de preocupação no âmbito do Direito Penal Econômico em razão do protagonismo que a empresa assume no contexto da economia moderna e a frequência com que o contexto corporativo tem propiciado o cometimento de delitos. A recente Lei n. ${ }^{\circ}$ 12.850/2013 tampouco aclarou esse panorama, na medida em que dispensou, para a formulação do conceito a organização criminosa, a utilização de métodos violentos e de outros expedientes intimidatórios, tal como Direito Italiano (cf. art. $1^{\mathrm{o}}, \S 1^{\mathrm{o}}$ ).

2. A associação imediata e irrefletida dos dois fenômenos organizativos (empresarial e criminoso) gera repercussões negativas tanto no Direito Penal como no Direito Processual Penal.

3. Promover, constituir, financiar ou integrar organização criminosa (cf. art. $2^{\circ}$ da Lei n. $\left.{ }^{\circ} 12.850 / 2013\right)$ não pode ser equiparado ao comportamento de promover constituir, financiar ou integrar organização empresarial, conquanto em ambas exista e seja imprescindível a pluralidade de pessoas, a divisão de tarefas, a hierarquia, a affectio e, pelo menos em regra, o fim de lucro.

4. Afigura-se oportuno adotar um critério objetivamente constatável que permita distinguir essas duas realidades sociais. Adotamos a concepção que existe um injusto autônomo e específico para as organizações criminosas (injusto sistêmico), desde que delineada uma estrutura concretamente projetada à atividade delituosa, composta de uma rede de papéis cambiáveis (a retirada do componente não afeta a permanência do aparato).

5. A sociedade empresária somente encontra conformação e significado na ordem jurídica; sua utilização para o cometimento de crimes contraria seu objeto social (necessariamente lícito) e, dessa forma, subverte a função social da empresa ${ }^{434}$.

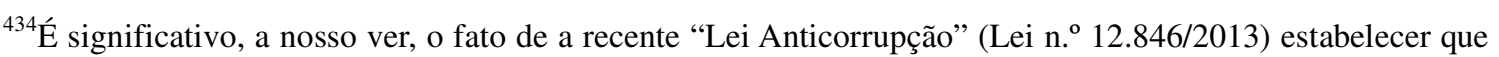
a dissolução compulsória da pessoa jurídica poderá ocorrer judicialmente quando comprovado: I - ter sido a personalidade jurídica utilizada de forma habitual para facilitar ou promover a prática de atos ilícitos; ou II
} 
6. A sociedade empresária criada com o intuito de proporcionar o sistemático cometimento de crimes deve equipara-se às organizações criminosas, uma vez presentes os requisitos do artigo $1^{\circ}, \S 1^{\circ}$, da Lei n. ${ }^{\circ} 12.850 / 2013$. Exemplos: as sociedades de "fachada", criadas com o propósito deliberado de encobrir atos criminosos e o caso citado do BCCI.

7. A sociedade empresária que nasce com finalidade lícita, mas que, no curso de sua vida corporativa, desvia-se de seu objeto social, transmudando-se em aparato para a prática de infrações penais graves, também será equiparada a uma organização criminosa. Neste caso, será imperioso verificar em que momento a sociedade adotou uma filosofia empresarial criminógena; somente a partir daí poderão incidir os dispositivos estampados na Lei n. ${ }^{\circ}$ 12.850/2013. Se uma instituição financeira, por exemplo, que necessariamente depende de autorização do Banco Central do Brasil para realizar suas operações no Brasil ${ }^{435}$, iniciar regularmente suas atividades, mas desvirtuá-las criminosamente posteriormente, passando seus diretores a apropriarem-se dos recursos financeiros de seus clientes ${ }^{436}$, ou, ainda, dedicando-se prioritariamente à reciclagem de recursos obtidos criminosamente, será possível a formulação de duas imputações penais autônomas aos indivíduos que tomaram parte da empreitada delitiva: uma em razão do injusto sistêmico, caracterizador de organização criminosa, outro pelo crime-fim facilitado estruturalmente ou incentivado pela organização.

\footnotetext{
- ter sido constituída para ocultar ou dissimular interesses ilícitos ou a identidade dos beneficiários dos atos praticados (cf. art. 19, $\S 1^{\circ}$ ). Em ambos os casos existe um patente desvio da personalidade jurídica da pessoa jurídica.

${ }^{435}$ Art. 18 da Lei n. ${ }^{4}$ 4.595/1964: As instituições financeiras somente poderão funcionar no País mediante prévia autorização do Banco Central da República do Brasil ou decreto do Poder Executivo, quando forem estrangeiras.

${ }^{436}$ Cometendo o crime do art. $5^{\circ}$ da Lei n. ${ }^{\circ}$ 7.492/1986: Apropriar-se, quaisquer das pessoas mencionadas no art. 25 desta lei, de dinheiro, título, valor ou qualquer outro bem móvel de que tem a posse, ou desviá-lo em proveito próprio ou alheio: Pena - Reclusão, de 2 (dois) a 6 (seis) anos, e multa.
} 


\section{OS APARATOS ORGANIZADOS DE PODER}

\subsection{Introdução: a teoria de Claus Roxin sobre os aparatos organizados de poder: uma hipótese de autoria mediata}

A teoria do domínio de vontade por intermédio de aparatos organizados de poder ou estruturas organizadas de poder foi desenvolvida por Claus Roxin em 1962 por ocasião de sua tese de habilitação, publicada em 1963 com o título “Autoria e Domínio do Fato em Direito Penal"437.

Roxin desenvolveu a teoria dos aparatos organizados de poder observando o contexto instaurado pelo domínio nacional-socialista na Alemanha e o julgamento do militar alemão Adolf Eichmann em Jerusalém, em 1961, chegando a afirmar que, quando "Hitler, Himmler ou Eichmann deram ordens de matar, podiam estar seguros de sua execução, pois, diferentemente de uma instigação, a eventual recusa de algum exortado, na execução da ordem, seria incapaz de fazer com que o fato ordenado não fosse levado a cabo. Neste contexto, o comando seria cumprido por outra pessoa" ${ }^{\natural 38}$. Eichmann, adiciona Roxin, não era apenas um cumpridor de ordens, um subordinado, mas uma peça importante da máquina nazista da qual promanavam ordens e determinações a outros subalternos ${ }^{439}$.

Esse aspecto foi notado pelo Tribunal regional de Jerusalém no julgamento de 1961, por ocasião da qual se percebeu, com peculiar precisão, que a responsabilidade do agente aumenta quanto mais distante ele estiver daquele que executa o fato criminoso e mais próximo da cadeia de comando do aparato ${ }^{440}$. A distância, esclarece Claus Roxin, se compensa justamente em virtude do domínio da organização, o qual vai aumentando proporcionalmente em conformidade com o

\footnotetext{
${ }^{437}$ ROXIN, Claus. Autoría y dominio del hecho en derecho penal, cit., p. 269 e ss.

${ }^{438}$ Id. Autoria mediata por meio de domínio de organização, cit., p. 324.

${ }^{439}$ Id. Autoría y dominio del hecho en derecho penal, cit., p. 274.

${ }^{440}$ Id. Ibid., p. 274.
} 
patamar ocupado na escala hierárquica do aparato $^{441}$.

A formulação teórica de Roxin derivou da teoria do domínio do fato, cuja principal função dogmática, como recordam Luís Greco e Alaor Leite, residiu em diferenciar o autor do partícipe em sentido amplo ${ }^{442}$.

Essa distinção tem particular relevância no Direito germânico, uma vez que o Código Penal alemão (StGB) exige que se aparte expressamente a figura do autor da do partícipe, pois a cumplicidade é punida com pena atenuada, enquanto o instigador recebe a mesma pena cominada ao autor ${ }^{443}$. Vale dizer: não se trata de uma discriminação ociosa ou que serve apenas a fins diletantes, ou, como preferem Luís Greco e Alaor Leite, a discriminação entre autor e partícipe "não é meramente simbólica, e sim prática",444.

A ideia central da teoria do domínio do fato é de que o autor, para assumir essa condição, deve ser o protagonista da ação típica. Pela perspectiva de Roxin, ao realizar a ação criminosa, o agente se coloca inegavelmente no centro do acontecer típico, e isso lhe confere inegavelmente o domínio do fato ${ }^{445}$.

No ponto, esclarecem Luís Greco e Alaor Leite que o "conceito de autor é primário e possui significado central no injusto típico, no sentido de que as formas de participação (a instigação e a cumplicidade) são causas de extensão da punibilidade, que só entram em cena quando o agente não é autor. O partícipe é, da perspectiva do tipo penal, quem contribui para um fato típico em caráter meramente secundário, é a figura marginal, lateral do acontecer típico, o que se extrai secundariamente, ante a ausência de algum dos elementos que determinam positivamente a autoria do fato" ${ }^{, 446}$.

\footnotetext{
${ }^{441}$ ROXIN, Claus. Autoría y dominio del hecho en derecho penal, cit., p. 274.

${ }^{442}$ GRECO, Luís; LEITE, Alaor. O que é e o que não é a teoria do domínio do fato sobre a distinção entre autor e partícipe no Direito Penal, cit., p. 62.

${ }^{443} \S 25$. Autoria. (1) É punido como autor, quem comete o fato por si mesmo ou por meio de outro. (2) Se vários cometem conjuntamente o fato, cada um é punido como autor (coautor). § 26. Instigação. É punido como instigador, com pena igual à do autor, quem determinou dolosamente outro ao cometimento de fato antijurídico doloso. $§ 27$. Cumplicidade. (1) É punido como cúmplice quem prestou dolosamente auxílio a outrem para o cometimento de fato antijurídico doloso. (2) A pena do cúmplice tem como base a cominação dirigida ao autor. Ele deve ser mitigada segundo o $\$ 49$, inciso 1.

${ }^{444}$ GRECO, Luís; LEITE, Alaor. O que é e o que não é a teoria do domínio do fato sobre a distinção entre autor e partícipe no Direito Penal, cit., p. 62.

${ }^{445}$ ROXIN, Claus. Autoría y dominio del hecho en derecho penal, cit., p. 163.

${ }^{446}$ Id. Ibid., p. 63.
} 
Não obstante, registre-se que a concepção teórica sobre o domínio do fato elaborada por Claus Roxin não pode ser tomada como princípio universal, ou seja, aplicável a toda sorte de delitos ${ }^{447}$. Deveras, sua validade encontra-se restrita aos "delitos dolosos gerais", também denominados "delitos de domínio", não servindo como critério para obtenção da autoria nos delitos de dever, também chamados de delitos de violação de dever, nos crimes de mão própria e nos crimes culposos ${ }^{448}$.

Na concepção de Claus Roxin o domínio do fato pode ser manifestar por intermédio de três realidades: (i) domínio da ação; (ii) domínio funcional do fato; e (iii) domínio da vontade ${ }^{449}$. O domínio da ação enseja o aparecimento da autoria imediata, haja vista que o agente controla a própria conduta. $\mathrm{O}$ domínio funcional do fato diz respeito à coautoria, pois existe a planificação de uma conduta e a divisão de funções na prática delitiva. Por fim, o domínio da vontade refere-se àquela situação na qual o sujeito - que está por trás - utiliza um terceiro (instrumento) para que este cometa o crime, dando azo à autoria mediata.

Roxin identificou três formas nas quais pode existir o domínio da vontade do instrumento sem que o autor (mediato) esteja presente no momento da execução da figura típica: (i) por coação do executor; (ii) enganando-se o executor; (iii) por ordens através de um aparato organizado de poder. Nas duas primeiras hipóteses, o sujeito que realiza concretamente a conduta típica (executor ou autor imediato), atua com a sua capacidade de discernimento alterada, diminuída ou mesmo eliminada, em razão da coação ou do erro $^{450}$ a que foi submetido. Na terceira forma - e foi essa, sem dúvida, a grande novidade e a principal contribuição de Roxin para o instituto da autoria mediata - a executora comporta-se com dolo, detém conhecimento pleno do caráter ilícito de sua

\footnotetext{
${ }^{447}$ ROXIN, Claus. Autoría y dominio del hecho en derecho penal, cit., p. 385 e ss.; DIAS, Jorge de Figueiredo. Direito penal: parte geral: questões fundamentais: a doutrina geral do crime, cit., t. 1, p. 767; GRECO, Luís; LEITE, Alaor. O que é e o que não é a teoria do domínio do fato sobre a distinção entre autor e partícipe no Direito Penal, cit., p. 65 e ss.

${ }^{448}$ DIAS, Jorge de Figueiredo. Direito penal: parte geral: questões fundamentais: a doutrina geral do crime, cit., t. 1, p. 767.

${ }^{449}$ ROXIN, Claus. Autoría y dominio del hecho en derecho penal, cit., p. 149.

${ }^{450}$ Claus Roxin escalona as categorias de erro nos seguintes termos: (i) o agente que erra de modo não doloso e sem culpa ou com imprudência inconsciente; (ii) o que realiza o tipo com imprudência consciente; (iii) o que executa a conduta dolosamente, mas sem consciência da antijuridicidade, (iv) ou com suposição errônea de um fato que exclui a culpabilidade; (v) o agente pratica conduta típica, antijurídica e culpável, apesar do erro; (vi) o executor realiza o evento que em sua pessoa é atípico ou lícito (Id. Ibid., p. 194).
} 
conduta, sendo, assim, penalmente responsável por seus atos ${ }^{451}$.

Não obstante, ele funciona como uma espécie de "instrumento" ao acatar as ordens e os direcionamentos que partem do órgão de comando da estrutura organizada. Sob essa circunstância, ou seja, no contexto do aparato, ele comete delitos na condição de autor imediato. De outro lado, quem emitiu as ordens de conteúdo antijurídico e comanda o aparato figura como autor mediato. Concretamente: pela teoria da autoria mediata mediante a utilização de aparatos organizados de poder torna-se possível atribuir responsabilidade penal àquele que, sem ostentar a condição de executor direto do fato criminoso (autor imediato), determina a sua perpetração a um subordinado que está vinculado ao aparato ou à organização. Para Roxin, verifica-se, nesta hipótese, um verdadeiro caso de autoria mediata e não de mera coautoria, haja vista a ausência de divisão de tarefas ou de um plano de mútuo acordo entre aquele ou aqueles que controlam ou comandam o aparato e o autor imediato ${ }^{452}$.

Demais disso, assinala Roxin ${ }^{453}$ que o aparato tem estrutura vertical ou piramidal, verificando-se um processo que se opera de cima para baixo, enquanto que a coautoria tem natureza horizontal, no sentido de que existem condutas paralelas, simultâneas, perpetradas em um mesmo plano.

Pela formulação teórica de Roxin, o aspecto primordial para fundamentar a existência do aparato organizado de poder e a correspondente autoria mediata por aquele que está por detrás o controlando reside na fungibilidade do executor ${ }^{454}$. Isso significa que os autores imediatos (que receberam as ordens do comando da organização) podem ser substituídos por outros sem que com isso exista solução de continuidade. A existência do aparato e seu automatismo conferem a certeza que a ordem emitida será cumprida por qualquer subordinado independentemente de seu conhecimento e responsabilidade penal ${ }^{455}$.

\footnotetext{
${ }^{451}$ FERNÁNDEZ IBÁÑEZ, Eva. La autoría mediata en aparatos organizados de poder, cit., p. 10. Em contrapartida, esse é, talvez, o ponto mais criticado da formulação teórica de Claus Roxin, como será visto oportunamente.

${ }^{452}$ Nesse sentido, sob a perspectiva do Direito penal brasileiro: BATISTA, Nilo. Concurso de agents: uma investigação sobre os problemas da autoria e da participação no direito penal brasileiro, cit.

${ }^{453}$ ROXIN, Claus. Autoría y dominio del hecho en derecho penal, cit., p. 726-727.

${ }^{454}$ Id. Ibid., p. 272.

${ }^{455}$ Id. Ibid., p. 272-273.
} 
Roxin ressalva, contudo, que, ao conceber a ideia do domínio de vontade por intermédio de um aparato organizado de poder, ele não teve a pretensão de formular algo pronto desde o início, ou mesmo estabelecer um conceito "fechado em si mesmo". Ao contrário: a teoria do domínio de vontade por intermédio de aparatos organizados de poder revela uma existência muito mais ideal do que real, cabendo, assim, à dogmática descrever seus elementos e atribuir a ela o espaço merecido na doutrina da autoria ${ }^{456}$. Vale dizer: sob o aspecto metodológico, a "ideia de domínio do fato não é uma definição de autor, mas um critério reitor que deve ser concretizado não pelo juiz no caso concreto, e sim pela doutrina diante de grupos de casos"

\subsection{Requisitos do aparato organizado de poder segundo Claus Roxin}

Claus Roxin desenvolveu a primeira versão da teoria da autoria mediata por intermédio de um aparato organizado de poder condicionando-a à caracterização prévia de três requisitos ${ }^{458}$ :

(i) A existência de um ente organizado e o correspondente poder de mando que decorre da estrutura hierárquica do aparato: existe uma cadeia hierárquica que proporciona a emissão de ordens por aqueles que têm competência aos subordinados que pertencem ao aparato, sendo irrelevante que a ordem beneficie ao próprio emissor ou a outras instâncias hierárquicas. O fundamental para a verificação da autoria, aponta Roxin, é a circunstância de que existe uma pessoa ou um grupo de pessoas que pode efetivamente dirigir a organização;

(ii) O aparato deve estar apartado ou dissociado do Direito: a atuação à margem do ordenamento jurídico (clandestinidade) outorga automatismo à organização e a certeza que as ordens serão integralmente cumpridas pelos seus destinatários. As ordens emitidas sob o contexto de uma organização juridicamente conformada podem ser

\footnotetext{
${ }^{456}$ ROXIN, Claus. Autoría y dominio del hecho en derecho penal, cit., p. 279.

${ }^{457}$ GRECO, Luís; LEITE, Alaor. O que é e o que não é a teoria do domínio do fato sobre a distinção entre autor e partícipe no Direito Penal, cit., p. 68.

${ }^{458}$ ROXIN, Claus. Autoría y dominio del hecho en derecho penal, cit., p. 276-278.
} 
descumpridas se ostentarem conteúdo ilegal, descaracterizando, assim, o funcionamento automático do aparato. Para Roxin, uma instrução antijurídica não pode colocar a organização em movimento, pois se ela for obedecida, não se trata de obra do maquinário de poder, mas de uma "iniciativa particular" levada a cabo pelo executor ${ }^{459}$. Por esse motivo, Claus Roxin somente vislumbra a existência do aparato de poder quando houver a caracterização de um "Estado dentro do Estado", o que ocorre, segundo ele, exclusivamente em três situações: (a) na criminalidade paraestatal, como, por exemplo, os regimes ditatoriais e de exceção constitucional; (b) nas organizações criminosas e (c) nas organizações terroristas. Apenas nessas três específicas hipóteses descolar-se-ia o aparato do ordenamento jurídico, tornando-se, portanto, clandestino ${ }^{460}$.

(iii) A fungibilidade dos executores (autores imediatos): a recusa no cumprimento de uma ordem do comando do aparato não interfere na sua concretização, pois existem outros subordinados dispostos a executá-la sem que o maquinário cesse suas atividades. $\mathrm{Na}$ interessante figura de linguagem desenhada por Roxin, o executor, conquanto detentor de vontade própria e plenamente responsável, funciona como uma espécie de engrenagem que pode ser substituída a qualquer tempo no seio do aparato de poder e é justamente essa circunstância que o coloca, em conjunto com o sujeito que está por detrás (autor de escritório ou autor de escrivaninha), no centro do acontecer típico ${ }^{461}$.

Posteriormente à edição de sua obra, Claus Roxin agregou um quarto elemento à configuração da autoria mediata, qual seja, a elevada disposição do cometimento do fato pelo autor: não obstante, ressalva Roxin que esse requisito não pode ser tratado como uma exigência ou um pressuposto autônomo para a existência do aparato, mas como uma derivação dos demais elementos do domínio por organização que, a despeito disso, fortalece o fundamento para o domínio do fato pelo homem que está por

\footnotetext{
${ }^{459}$ ROXIN, Claus. Autoría y dominio del hecho en derecho penal, cit., p. 277.

${ }^{460}$ GRECO, Luís; LEITE, Alaor. O que é e o que não é a teoria do domínio do fato sobre a distinção entre autor e partícipe no Direito Penal, cit., p. 65. No mesmo diapasão: FARALDO CABANA, Patricia. Responsabilidad penal del dirigente en estructuras jerárquicas: la autoría mediata con aparatos organizados de poder. Valencia: Tirant lo Blanch, 2004. p. 31. (Monografías, n. 302); MEINI, Iván. Responsabilidad penal del empresario por los hechos cometidos por sus subordinados. Valencia: Tirant lo Blanch, 2003. p. 116-117. Por tal razão Roxin não admite a incidência da sua teoria às empresas, tema que será explorado de forma detida mais adiante.

${ }^{461}$ ROXIN, Claus. Autoría y dominio del hecho en derecho penal, cit., p. 273.
} 
detrás da estrutura organizada ${ }^{462}$.

Vale destacar que Roxin aproximou-se, neste ponto, ao menos parcialmente $^{463}$, da concepção de Friedrich-Christian Schroeder, que desde o ano de 1965 tem sustentado que o elemento essencial na busca da autoria de delitos levados a efeito em ambientes organizados reside no aproveitamento da firme resolução do autor imediato em perpetrar a conduta criminosa ${ }^{464}$. Para Schroeder, não é a fungibilidade do autor imediato que confere substância à autoria mediata daquele que está no topo do aparato, mas a utilização da predisposição do executor em cometer a infração penal. A fungibilidade do autor imediato, arremata Schroeder, proporciona apenas um meio para a obtenção do domínio do fato, mas não constitui seu fundamento ${ }^{465}$.

De todo modo, a postura atual de Claus Roxin tem reclamado a presença dos quatro supramencionados requisitos para a caracterização, como autor mediato, do agente que comanda o aparato organizado de poder, sendo certo que essa configuração tem sido acolhida amplamente pelos mais diversos Tribunais Penais ${ }^{466}$, merecendo especial destaque, no ponto, a decisão da Sala Especial da Corte Suprema do Peru, prolatada em 2009 no Caso Fujimori/La Cantuta/Barrios Altos.

\subsection{Críticas à autoria mediata delineada por Claus Roxin}

A principal crítica doutrinária à admissão da teoria do domínio de vontade em virtude de aparatos organizados de poder reside no fato de o autor imediato (executor) constituir-se em um indivíduo plenamente responsável, isto é, que não incide em erro, que atua sem dolo ou que não se encontra de algum modo coagido. Dessa forma, argumenta-se

\footnotetext{
${ }^{462}$ ROXIN, Claus. Apuntes sobre la Sentencia-Fujimori de la Corte Suprema del Perú. In: AMBOS, Kai; MEINI, Iván (Eds.). La autoría mediata: el caso Fujimori. Lima-Peru: Ara Editores, 2010. p. 100-101.

${ }^{463}$ Id. Ibid., p. 99. No mesmo sentido: ROTSCH, Thomas. De Eichmann hasta Fujimori. In: AMBOS, Kai; MEINI, Iván (Eds.). La autoría mediata: el caso Fujimori. Lima-Peru: Ara Editores, 2010. p. 39.

${ }^{464}$ SCHROEDER, Friedrich-Christian. Disposición al hecho versus fungibilidad. In: AMBOS, Kai; MEINI, Iván (Eds.). La autoría mediata: el caso Fujimori. Lima-Peru: Ara Editores, 2010. p. 118.

${ }^{465}$ Id. Ibid., p. 118.

${ }^{466}$ GRECO, Luís; LEITE, Alaor. O que é e o que não é a teoria do domínio do fato sobre a distinção entre autor e partícipe no Direito Penal, cit., p. 65.
} 
que não se pode atribuir àquele indivíduo que está por detrás da conduta ("autor de escritório" ou "autor escrivaninha") a condição de autor, ainda que mediato ${ }^{467}$. Sendo assim, haveria espaço apenas para o aparecimento da coautoria ou da instigação.

Para Günther Jakobs, aquele que emite a ordem assume, em conjunto com o executor, a condição de coautor, notadamente porque eles (executores), no interior do aparato organizado de poder, precisamente porque operam de maneira responsável, não constituem instrumento algum ${ }^{468}$. No ponto, aliás, vale mencionar que a posição de Jakobs deriva do fato de que ele dispensa, para a caracterização da coautoria, a existência de um plano comum e a presença dos agentes no momento da execução da figura delituosa, os quais constituem requisitos imprescindíveis na concepção de Claus Roxin ${ }^{469}$.

A dispensa da presença de todos os agentes no ato da execução da infração penal também motiva Francisco Muñoz Conde a defender a existência de coautoria. De fato, Muñoz Conde defende que a ideia de coautoria não fica restrita ao plano executivo do crime ("coautoria executiva”), mas abrange outras formas de realização conjunta do delito, ainda que algum ou alguns dos coautores, talvez os mais importantes, não estejam presentes no momento da execução ${ }^{470}$. O fator fundamental não se encontra vinculado à execução propriamente do ato ilícito, ressalta Muñoz Conde, mas ao domínio do fato por parte do indivíduo que se encontra na cúspide da organização, ainda que ele não intervenha concretamente no evento. Daí que se consideram coautores de um delito não somente o líder ou dirigentes de um grupo criminoso que empunham funções de decisão, direção e

\footnotetext{
${ }^{467}$ JESCHECK, Hans-Henrich; WEIGEND, Thomas. Tratado de derecho penal: parte general, cit., p. 715.

${ }^{468}$ JAKOBS, Günther. Sobre la autoría del acusado Alberto Fujimori Fujimori. In: AMBOS, Kai; MEINI, Iván (Eds.). La autoría mediata: el caso Fujimori. Lima-Peru: Ara Editores, 2010. p. 108.

${ }^{469}$ A qualificação da coautoria de Jakobs se baseia, segundo Roxin, em uma concepção mais normativa do domínio do fato, derivada da responsabilidade jurídica, do que um domínio real (ROXIN, Claus. Autoría y dominio del hecho en derecho penal, cit., p. 725-726). Também com crítica à tese da coautoria, veja-se Patricia Faraldo Cabana, para quem o fato de existir hierarquia verticalizada no aparato organizado de poder - e não horizontal - represente um argumento de peso contrário à coautoria, por parecer incorreto em tais casos atribuir o mesmo nível de responsabilidade a todos os intervenientes do fato (FARALDO CABANA, Patricia. Responsabilidad penal del dirigente en estructuras jerárquicas: la autoría mediata con aparatos organizados de poder, cit., p. 158). Para outra ordem de críticas à admissão de coautoria no âmbito de aparatos organizados de poder: MARÍN DE ESPINOSA CEBALLOS, Elena B. Criminalidad de empresa: la responsabilidad penal en las estructuras jerárquicamente organizadas. Valencia: Tirant lo Blanch, 2002. p. 110-111. (Monografías, n. 256).

${ }^{470}$ MUÑOZ CONDE, Francisco. Problemas de autoría y participación en el derecho penal económico, o ¿cómo imputar a título de autores a las personas que sin realizar acciones ejecutivas, deciden la realización de un delito en el ámbito de la delincuencia económica empresarial?, cit., p. 66.
} 
organização estreitamente relacionadas com os que são parte integrante fundamental da realização do delito, senão também os componentes da agremiação que, sem participar da execução da infração, realizam durante ela tarefas de apoio, vigilância e transporte"471.

No mesmo sentido, apregoando um caso de coautoria, Jescheck observa que o princípio norteador do domínio do fato pelo homem que se encontra por detrás do evento delitivo baseia-se em uma situação de inferioridade do executor, e que essa inferioridade não existe quando aquele que realiza a conduta com suas próprias mãos é responsável por seus $\operatorname{atos}^{472}$. Especificamente sobre a proposta de Roxin e a mencionada ausência de um necessário plano comum para a categorização da coautoria, Jescheck contrapõe-se sustentando que o caráter comum da resolução delitiva se produz por intermédio da consciência do dirigente da organização e dos executores de que um ou vários fatos criminosos determinados da mesma natureza devem ser cometidos em estrita consonância com os planos traçados pela cúpula do aparato organizado de poder ${ }^{473}$.

Outra crítica direcionada à teoria de Claus Roxin revela-se na afirmação de que o sujeito que emite a ordem ostenta a condição jurídica de indutor ou instigador e não de autor mediato. E isso porque não se pode cogitar de autoria, ainda que mediata, se o executor apresenta absoluto e pleno conhecimento do caráter ilícito de sua conduta ${ }^{474}$.

Não obstante, a denominada "renúncia" ou "ruptura do princípio da responsabilidade" na elaboração da autoria mediata não tem assumido a relevância pretendida pelos opositores de Roxin, em especial porque não se pode negar e, consequentemente, valorar a notável ascendência exercida pelo indivíduo ou grupo de indivíduos que se encontram no ápice da estrutura organizada de poder sobre os subordinados. Assim, Patricia Faraldo Cabana refuta a utilização da figura da indução para o controlador, observando, com razão, que ele não precisa convencer o subalterno sobre a

\footnotetext{
${ }^{471}$ MUÑOZ CONDE, Francisco. Problemas de autoría y participación en el derecho penal económico, o ¿cómo imputar a título de autores a las personas que sin realizar acciones ejecutivas, deciden la realización de un delito en el ámbito de la delincuencia económica empresarial?, cit., p. 67.

${ }^{472}$ JESCHECK, Hans-Henrich; WEIGEND, Thomas. Tratado de derecho penal: parte general, cit., p. 716.

${ }^{473}$ Id. Ibid., p. 722. Francisco Muñoz Conde também é adepto da coautoria (Problemas de autoría y participación en el derecho penal económico, o ¿cómo imputar a título de autores a las personas que sin realizar acciones ejecutivas, deciden la realización de un delito en el ámbito de la delincuencia económica empresarial?, cit., p. 73).

${ }^{474}$ DIAS, Jorge de Figueiredo. Direito penal: parte geral: questões fundamentais: a doutrina geral do crime, cit., t. 1, p. 790 .
} 
conveniência de praticar a conduta delituosa, pois tem o conhecimento - ou mesmo a certeza, diríamos, em razão do automatismo do aparato - de que a ordem será rigorosamente executada por qualquer pessoa que dela tomar conhecimento ${ }^{475}$.

Ademais, como bem evidencia Iván Meini, se existir mesmo a pretensão de aplicar o princípio da responsabilidade aos casos de "autor detrás do autor", deve-se ter presente a ideia de que se trata de uma categoria jurídica nova que refoge das clássicas concepções de autoria e de participação que, por sinal, se revelaram insuficientes para a resolução de casos complexos ${ }^{476}$. Dessa forma, arremata Meini apontando que "históricamente el principio de responsabilidad responde a concepciones que entienden que el dominio del hecho que ha de tener el autor mediato sobre el instrumento es un dominio fáctico, algo que, ciertamente, nos es admisible en los aparatos de poder organizado"477.

Raúl Pariona Arana também repele o reproche calcado no postulado da responsabilidade, argumentando tal princípio pode ter alguma influência para a imputação objetiva ao proporcionar a delimitação dos diversos planos de responsabilidade, mas que ele não emerge como um critério adequado para a delimitação das distintas modalidades de participação, particularmente porque a responsabilidade penal do autor mediato não obsta, sob qualquer aspecto, a atribuição de responsabilidade penal do partícipe ${ }^{478}$.

Outra perspectiva crítica pode ser contemplada através de um grupo doutrinário que, conquanto acolha a formulação teórica de Claus Roxin e, dessa forma, reconheça que o dirigente de um aparato organizado de poder que determina o cometimento de crimes a seus subordinados deva ser imputado penalmente como autor mediato, rechaça, em maior ou menor medida, a natureza dos requisitos exigidos pelo professor alemão para a configuração do aparato. Em outro dizer: preconiza a mitigação, ou até mesmo a dispensa, da fungibilidade dos executores, da presença do automatismo e da necessidade de o aparato afigurar-se dissociado ou apartado do ordenamento jurídico.

\footnotetext{
${ }^{475}$ FARALDO CABANA, Patricia. Responsabilidad penal del dirigente en estructuras jerárquicas: la autoría mediata con aparatos organizados de poder, cit., p. 174; BOLEA BARDON, Carolina. Autoría mediata en derecho penal, cit., p. 370 e ss.

${ }^{476}$ MEINI, Iván. Responsabilidad penal del empresario por los hechos cometidos por sus subordinados, cit., p. 119-120.

${ }^{477}$ Id. Ibid., p. 119.

${ }^{478}$ PARIONA ARANA, Raúl. Autoría mediata por organización: consideraciones sobre su fundamentación y aplicación. Lima-Peru: Ed. Jurídica Grijley, 2009. p. 35.
} 
Em relação à fungibilidade dos executores, não se pode olvidar a pioneira crítica - de resto mencionada anteriormente - de Friedrich-Christian Schroeder, no sentido de que não é a fungibilidade do autor imediato que confere essência à autoria mediata de quem ocupa o ápice do aparato, mas a utilização da predisposição do executor em cometer a infração penal ${ }^{479}$. Sem embargo, é certo que a opinião de Schroeder foi posteriormente acolhida por Roxin, que introduziu, em consequência, um quarto requisito do aparato ${ }^{480}$.

Além disso, afirma-se que nos casos de crimes mais complexos, os quais exigem do executor determinada qualidade pessoal especial, não existiria substitutibilidade. Como aponta Dino Carlos Caro Coria, nas hipóteses em que o executor direto é indispensável para realizar o delito, seja pelo seu alto nível de especialização, seja pela sua proximidade com o objeto material da conduta, a fungibilidade emergiria impossível ${ }^{481}$.

No que tange à presença do automatismo como característica do funcionamento do aparato organizado de poder, anota Patricia Faraldo Cabana que ele tem sido confundido por alguns setores da doutrina com a ausência de liberdade do executor ${ }^{482}$, o que, evidentemente, desvirtua e compromete a crítica. Por automatismo deve-se compreender a potencialidade concreta de o aparato funcionar independentemente, ou como se fora "máquina", na busca do desiderato criminoso. Sob esse panorama, a disposição do agente para o cometimento do fato delituoso emerge secundária, quiçá ociosa, tendo em vista que o comando da organização tem a convicção de que ordem será regiamente cumprida por qualquer subordinado que no momento estava disponível ${ }^{483}$.

Por fim, a desvinculação ou dissociação do ordenamento jurídico. Pela concepção original desenvolvida por Claus Roxin, somente existe autoria mediata pelo domínio da organização quando houver a caracterização de uma estrutura hierárquica que

\footnotetext{
${ }^{479}$ SCHROEDER, Friedrich-Christian. Disposición al hecho versus fungibilidad, cit., p. 118.

${ }^{480}$ ROXIN, Claus. Apuntes sobre la Sentencia-Fujimori de la Corte Suprema del Perú, cit., p. 99.

${ }^{481}$ CARO CORIA, Dino Carlos. Sobre la punición del ex presidente Alberto Fujimori. In: AMBOS, Kai; MEINI, Iván (Eds.). La autoría mediata: el caso Fujimori. Lima-Peru: Ara Editores, 2010. p. 176.

${ }^{482}$ FARALDO CABANA, Patricia. Responsabilidad penal del dirigente en estructuras jerárquicas: la autoría mediata con aparatos organizados de poder, cit., p. 92.

${ }^{483}$ ROXIN, Claus. Autoría y dominio del hecho en derecho penal, cit., p. 278; FARALDO CABANA, Patricia. Responsabilidad penal del dirigente en estructuras jerárquicas: la autoría mediata con aparatos organizados de poder, cit., p. 95.
} 
atue à margem do Direito. Para Roxin, a vinculação dos órgãos de direção e de execução do aparato ao ordenamento jurídico desnatura o caráter cogente das determinações ilegais, especialmente porque as leis excluem o cumprimento de ordens antijurídicas, afastando, com isso, o próprio domínio da vontade pelo sujeito que está por trás ${ }^{484}$. Dessa forma, apenas as organizações paraestatais, as organizações criminosas e as organizações terroristas podem se constituir em aparatos de poder e ensejar a autoria mediata ${ }^{485}$.

Kai Ambos frequentemente tem criticado esse requisito para a configuração do aparato, ao menos na forma propugnada por Roxin, acenando, para tanto, com o caso da criminalidade de Estado. Para Ambos, nas organizações paraestatais o aparato de poder atua "sem desvincular-se do direito - ao menos sem desvincular-se do direito positivo, e sim no máximo do direito suprapositivo (direito natural)" "486. Como consequência desse raciocínio, Kai Ambos propõe que se observe o critério da desvinculação sob um duplo enfoque: o primeiro, relacionado ao Direito positivo, escrito ou posto; o segundo, pertinente ao Direito suprapositivo, não escrito. "que só poderia existir de modo excepcional em determinados aparatos de poder estatais e que pode ser nomeada como desvinculação do direito 'suprapositivo",487.

Ao criticar a postura de Roxin, Kai Ambos sugere, em complemento, que se observem outras duas formas de desvinculação do ordenamento jurídico: uma em sentido estrito (stricto sensu) e outra em sentido amplo (lato sensu) ${ }^{488}$. A diferença entre a chamada desvinculação do direito em sentido estrito e a em sentido amplo, para Ambos, "reside manifestamente em que aquela infração é mais clara e palpável que esta e, por isto, pode-se falar realmente em uma barreira normativa à execução da ordem que deve ser cumprida. Enquanto a lesão do direito positivo é reconhecível por um executor mediano ou, em todo caso, deve ser considerada reconhecível - no sentido de uma ficção necessária para o Estado -, não se pode afirmar o mesmo de nenhuma maneira a respeito de uma lesão do

\footnotetext{
${ }^{484}$ ROXIN, Claus. Autoría y dominio del hecho en derecho penal, cit., p. 277.

${ }^{485}$ Id. Ibid., p. 277-278.

${ }^{486}$ AMBOS, Kai. A parte geral do direito penal internacional: bases para uma elaboração dogmática, cit., p. 272.

${ }^{487}$ Id. Ibid., p. 272.

${ }^{488}$ Id. Ibid., p. 272.
} 
direito suprapositivo" ${ }^{489}$.

Portanto, a única conclusão razoável para Kai Ambos é a de que o critério da desvinculação do Direito somente serve como requisito do aparato organizado de poder se cogitar-se de uma dissociação do Direito positivo. Se atrelado o requisito ao Direito suprapositivo, tal como defendido por Claus Roxin, haverá mais problema do que solução, por ele se afigurar extremamente vago, carecendo de precisão. A utilidade prática deste critério, finaliza Kai Ambos, "não é evidente, podendo-se prescindir dele"490.

Adotando semelhante linha de pensamento, Iván Meini não empresta à desvinculação do ordenamento jurídico a mesma relevância conferida por Roxin, tratandoa muito mais como uma eventual característica do domínio de vontade em razão do domínio da organização do que um verdadeiro pressuposto da formação do aparato de poder $^{491}$. Por conseguinte, concluiu Meini que a eventual ausência da dissociação não impedirá a imputação penal daquele que comanda da organização na condição de autor mediato dos delitos perpetrados pelos seus subordinados no âmbito da organização ${ }^{492}$.

A posição de Rolf Herzberg é ainda mais radical, alcançando o núcleo da teoria de Claus Roxin, e, na mesma medida, criativa e inovadora, principalmente se cotejada com as demais orientações doutrinárias anteriormente analisadas. Sim, porque, em primeiro lugar, Herzberg refuta a utilidade dogmática dos célebres termos usados por Roxin para condicionar a existência do aparato organizado de poder: fungibilidade, rodinhas intercambiáveis e engrenagem nada mais representam do que "conceitos de ajuda" e "metáforas" 493 . Em seguida, Herzberg propõe que diante do delito cometido por ordens de superiores, caberá ao juiz o papel de impor as balizas e as condições e, assim,

\footnotetext{
${ }^{489}$ AMBOS, Kai. A parte geral do direito penal internacional: bases para uma elaboração dogmática, cit., p. 273-274. Kai Ambos refere que Claus Roxin mitigou a sua posição original sobre o requisito da desvinculação do Direito em decorrência das críticas formuladas pelo próprio Ambos (Id. Ibid., p. 272273). Também sobre a guinada de Roxin: FERNÁNDEZ IBÁÑEZ, Eva. La autoría mediata en aparatos organizados de poder, cit., p. 185.

${ }^{490}$ AMBOS, Kai. A parte geral do direito penal internacional: bases para uma elaboração dogmática, cit., p. 279.

${ }^{491}$ MEINI, Iván. Responsabilidad penal del empresario por los hechos cometidos por sus subordinados, cit., p. 180. ${ }^{492}$ Id. Ibid., p. 180.

${ }^{493}$ HERZBERG, Rolf D. La Sentencia-Fujimori: sobre la intervención del superior en los crímenes de su aparato de poder. In: AMBOS, Kai; MEINI, Iván (Eds.). La autoría mediata: el caso Fujimori. Lima-Peru: Ara Editores, 2010. p. 131.
} 
verificar, em cada caso concreto, se a organização sob cujo contexto a determinação ilegal foi emanada consubstanciava, ou não, um verdadeiro "aparato organizado de poder"494.

Por fim, Eva Fernández Ibáñez defende a prescindibilidade da dissociação do Direto para definir a incidência do aparato organizado de poder. Com efeito, após referir-se a diversos personagens históricos que, de alguma maneira, comandaram notórios aparatos de poder que não estavam apartados do Direito, como sucedeu como Hitler, Jorge Videla e Polpot, Eva Fernández Ibáñez assevera que em todos esses casos os executores cumpriram livre e responsavelmente as instruções de seus superiores sem que a organização estivesse juridicamente dissociada ${ }^{495}$.

Para Fernández Ibáñez, à caracterização da autoria mediata bastará a demonstração de que, faticamente, o dirigente está dominando o fato, e que a regularidade do processo causal e os requisitos da hierarquia e da fungibilidade estarão presentes no caso submetido à análise ${ }^{496}$. Em síntese, Fernández Ibáñez defende a exclusão do requisito propugnado por Roxin e a consequente extensão da teoria do domínio de vontade por intermédio de aparatos organizados de poder a organizações que não estejam apartadas do Direito, ou seja, que por si sós não sejam de natureza delitiva, desde que, evidentemente, demonstrados os demais pressupostos da fungibilidade, da hierarquia e do automatismo ${ }^{497}$.

\subsection{Conclusão}

A despeito das diversas críticas, a essência da teoria do domínio de vontade através de aparatos organizados de poder tem sido acolhida majoritariamente na doutrina e a sua importância não pode, sob nenhum aspecto, ser minimizada. "É tarefa árdua advertem Luís Greco e Alaor Leite - a de avaliar com exatidão a importância da obra, sua riqueza de ideias e a dimensão de sua influência na doutrina e na jurisprudência, tanto

\footnotetext{
${ }^{494}$ HERZBERG, Rolf D. La Sentencia-Fujimori: sobre la intervención del superior en los crímenes de su aparato de poder, cit., p. 131.

${ }^{495}$ FERNÁNDEZ IBÁÑEZ, Eva. La autoría mediata en aparatos organizados de poder, cit., p. 201.

${ }^{496}$ Id. Ibid., p. 202.

${ }^{497}$ Id. Ibid., p. 202.
} 
alemã, como estrangeira" ${ }^{" 498}$. De fato, a consideração teórica daquele que emite ordens no contexto de uma organização hierarquicamente estruturada como autor mediato tem constituído o manancial dogmático de relevantes decisões judiciais proferidas na Alemanha, na Espanha e também na América do Sul, com destaque, neste último caso, para as decisões judiciais proferidas pelo Poder Judiciário argentino e pelo Poder Judiciário peruano, as quais serão objeto de individualizada análise no próximo subitem. Confira-se.

\subsection{A teoria dos aparatos organizados de poder na jurisprudência}

A teoria da autoria mediata por intermédio de aparatos organizados de poder surgiu, consoante assinalado, da observação e análise, por Claus Roxin, do julgamento do nazista Adolf Eichmann, em 1961. Seu impacto foi tamanho que ela não ficou restrita ao território alemão, alcançando, em medidas diferentes, mas preservada a essência, outros continentes. Além da própria Alemanha, os Poderes Judiciários da Argentina e do Peru tiveram a oportunidade de lançar mão do manancial dogmático desenvolvido por Roxin para resolver problemas concretos atinentes à imputação penal de condutas praticadas em ambientes hierárquicos, organizados e dissociados do ordenamento jurídico.

O mesmo sucedeu no âmbito do Direito Penal Internacional, por força do julgamento do Caso Katanga/Ngujdolo Chui pela Sala de Assuntos Preliminares do Tribunal Penal Internacional em 30 de setembro de $2008^{499}$. Em todos esses casos, porém,

\footnotetext{
${ }^{498}$ GRECO, Luís; LEITE, Alaor. O que é e o que não é a teoria do domínio do fato sobre a distinção entre autor e partícipe no Direito Penal, cit., p. 62.

${ }^{499}$ AMBOS, Kai. La autoría mediata por organización en la sentencia contra Fujimori: transfondos políticos y jurídicos de la sentencia contra el ex presidente peruano Alberto Fujimori. In: AMBOS, Kai; MEINI, Iván (Eds.). La autoría mediata: el caso Fujimori. Lima-Peru: Ara Editores, 2010. p. 74 e p. 89. Ressalta Ambos, a "teoria do domínio da organização assume uma importância central no direito penal internacional por causa do deslocamento vertical da responsabilidade de baixo (do autor direto) para cima (ao autor mediato 'de escritório')" (AMBOS, Kai. A parte geral do direito penal internacional: bases para uma elaboração dogmática, cit., p. 95). A aceitação da autoria mediata em virtude do aparato organizado de poder derivaria, na perspectiva de Kai Ambos, do disposto no art. 25, 3, "a”, do Estatuto de Roma, internalizado no Brasil em 25 de setembro de 2002 pela promulgação do Decreto n. ${ }^{\circ}$ 4.388, a saber: Nos termos do presente Estatuto, será considerado criminalmente responsável e poderá ser punido pela prática de um crime da competência do Tribunal quem: a) Cometer esse crime individualmente ou em conjunto ou por intermédio de outrem, quer essa pessoa seja, ou não, criminalmente responsável. No mesmo sentido, Claus Roxin, Apuntes sobre la Sentencia-Fujimori de la Corte Suprema del Perú, cit., p. 95 e p. 101.
} 
é possível detectar um elo ou linha comum que permeou a análise judicial: a perpetração de delitos por agentes estatais no contexto de regimes de exceção. De fato, na totalidade de julgamentos as Cortes de Justiça se debruçaram sobre situações nas quais altos mandatários públicos (membros do Conselho de Defesa e Presidentes da República), valendo-se do elevado posto que ocupavam, emitiram ordens a subordinados com conteúdo criminoso.

\subsubsection{O julgamento dos Comandantes das Juntas Militares Argentinas (1985 e 1986)}

É comum, na doutrina, a referência ao julgamento dos Comandantes das Forças Armadas Argentinas por fatos praticados durante a ditadura militar instaurada naquele país entre os anos de 1976 e 1983 como sendo o primeiro "teste prático" da teoria da autoria mediata por aparado organizado de poder, ao menos nos moldes concebidos por Claus Roxin ${ }^{500}$.

O panorama fático era o seguinte: por volta do dia 24 de março de 1976, data do golpe militar que ensejou a ascensão do General Jorge Rafael Videla à presidência da República argentina, foram perpetrados inúmeros crimes contra os direitos humanos, relacionados, em sua maioria a homicídios, tortura e desaparecimento forçado de cidadãos. Sob o argumento de que havia necessidade de se travar uma luta contra o terrorismo, a cúpula militar argentina ordenou uma série de medidas atentatórias aos direitos humanos, como a captura, o interrogatório e a tortura de supostos membros de agremiações "subversivas". Tudo se desenvolveu sob a mais absoluta clandestinidade, uma vez que existiam orientações no sentido de que os executores das ordens emitidas ocultassem suas identidades, que as diligências fossem concretizadas no período noturno, que as vítimas fossem mantidas incomunicáveis sempre com os olhos vendados e que se negasse o fato de que o cidadão sequestrado estava em poder das Forças Armadas.

A Câmara Nacional de Apelação Criminal e Correcional, órgão julgador argentino, concluiu pela existência de provas no sentido de que foram emanadas diversas

${ }^{500}$ FARALDO CABANA, Patricia. Responsabilidad penal del dirigente en estructuras jerárquicas: la autoría mediata con aparatos organizados de poder, cit., p. 32-33. 
ordens aos membros das Forças Armadas, as quais deram azo à concretização das aludidas violações. Ademais, a instrução processual indicou que os militares de alta patente, que ocupavam a cúspide do aparato militar, não intervieram diretamente em nenhuma das condutas realizadas pelos subordinados. Em razão disso, o Ministério Público argentino preconizou a condenação dos Comandantes das Forças Armadas Argentinas como autores mediatos dos delitos praticados, referindo-se expressamente à existência de um aparato organizado de poder que permitiu determinar a causalidade através da fungibilidade dos executores, fato que assegurou a consumação de tais infrações penais ${ }^{501}$.

A Câmara Nacional acolheu a postulação do Ministério Público e adotou a teoria de Roxin para fundamentar a responsabilidade penal dos Comandantes das Forças Armadas $^{502}$, ressaltando, naquela oportunidade, o pressuposto da fungibilidade do executor como motivo para a compreensão da autoria mediata, ainda que o executor (autor imediato) se revele, quando do cometimento do fato criminoso, plenamente responsável ${ }^{503}$. Sob esse prisma, assentou a Câmara que a figura do executor material, por assumir uma condição secundária no desdobramento dos fatos, perde relevância, sendo substituído por quem efetivamente domina a anônima vontade de todos os homens que integram o sistema $\operatorname{organizado}^{504}$.

Ainda no que tange aos requisitos do aparato de poder, ressalta Iván Meini que o julgamento argentino, ocorrido em 1985, não apreciou a predisposição do executor para cometer o crime ordenado pela cúpula do aparato como requisito da autoria mediata, embora a Câmara Criminal, ainda que indiretamente e sem o uso dessa terminologia, tenha chegado próximo da conclusão de que a predisposição do executor constituiu efetivamente um fator importante no cometimento dos fatos

\footnotetext{
${ }^{501}$ FARALDO CABANA, Patricia. Responsabilidad penal del dirigente en estructuras jerárquicas: la autoría mediata con aparatos organizados de poder, cit., p. 35.

${ }^{502} \mathrm{O}$ reconhecimento da autoria mediata pela Câmara Criminal deu-se, entretanto, em sentido meramente simbólico ou teórico, como aponta Ezequiel Malarino, pois atrelou a responsabilidade penal dos comandantes nessa categoria à responsabilidade dos executores (autores imediatos), tratando aqueles, na prática, como partícipes necessários (MALARINO, Ezequiel. El caso argentino: imputación de crímenes de los subordinados al dirigente: un estudio comparado. Bogotá: Editorial Temis, 2008. p. 60).

${ }^{503}$ MEINI, Iván. Responsabilidad penal del empresario por los hechos cometidos por sus subordinados, cit., p. 134-135.

${ }^{504}$ Id. Ibid., p. 136-137.
} 
criminosos desencadeados no interior do aparato $^{505}$.

O julgamento argentino também enfrentou o tema da eventual existência de coautoria entre os comandantes e os executores, em virtude de uma suposta divisão de tarefas, descartando-a, porém, quando da conclusão do julgamento, sob o fundamento de que inexistiria "justificativa relevante" para a sua acolhida, e que, na mesma medida, afigurar-se-ia "mais útil" manter a qualificação dos comandantes militares como autores mediatos $^{506}$.

Ao final, a Câmara Nacional Criminal e Correcional considerou Jorge Rafael Videla ${ }^{507}$ e outros comandantes militares como autores mediatos dos numerosos homicídios qualificados, privações ilegais da liberdade, torturas, roubos qualificado, falsidades ideológicas de documento público, usurpações, reduções à condição de escravo, extorsão, sequestros, supressão de documentos, subtrações de menores, e diversas torturas seguidas de morte levadas a efeito no contexto do Estado totalitário instaurado em 1976, aplicando, na íntegra, a teoria desenvolvida por Claus Roxin vinte e cinco anos antes do julgamento $^{508}$.

Em 30 de dezembro de 1986, contudo, a sentença da Câmara Nacional Criminal e Correcional teve seus fundamentos reformados pela Corte Suprema argentina,

\footnotetext{
${ }^{505}$ MEINI, Iván. El dominio de la organización en derecho penal. Lima-Perú: Palestra Editores, 2008. p. 138. Para Iván Meini, o fato de não se mencionar expressamente o requisito da predisposição ao cometimento do crime como requisito pode decorrer do fato de que, em organizações com muitos componentes dispostos ao cumprimento de ordens, deixa-se, talvez pela obviedade, de mencionar essa circunstância como fundamento do aparato. Todavia, para Meini, o coletivo indeterminado e ilimitado de pessoas disponíveis à execução das ordens constitui o dado mais importante na formatação do aparato de poder (Id. Ibid., p. 138).

${ }^{506}$ Em tom crítico, Iván Meini observa, com acerto, que essa fundamentação da Câmara Criminal não pode ser aceita sem reservas, a não ser que se aceite que a tentativa na coautoria em aparatos de poder inicia-se com a emissão das ordens pela cúpula da organização, e a partir desse momento pode-se cogitar da punição do autor imediato (executor) pela sua vinculação ao aparato, ainda que ele desista da perpetração do crime ordenado, e que, de outro lado, a tentativa da autoria mediata em aparatos de poder tem início para o executor (instrumento) quando do começo da execução da ordem (Id. Ibid., p. 140).

${ }^{507}$ Videla passou cinco anos na prisão, pois no ano de 1990 o então presidente Carlos Menem o indultou, junto com outros membros de juntas militares e chefes da polícia de Buenos Aires. Em 1998 Jorge Videla regressou à prisão, embora por curto período, pela acusação de subtração de menores durante a chamada Guerra Suja. Em 2010 Videla foi condenado à prisão perpétua pela prática crimes contra a humanidade durante a ditadura militar. Em 2012 houve uma nova condenação, pela subtração sistemática de menores que eram filhos de presos políticos mortos ou desaparecidos. Jorge Rafael Videla morreu na prisão, em 17 de maio de 2013, aos 87 anos.

${ }^{508}$ FARALDO CABANA, Patricia. Responsabilidad penal del dirigente en estructuras jerárquicas: la autoría mediata con aparatos organizados de poder, cit., p. 41.
} 
que vislumbrou, por maioria de $\operatorname{votos}^{509}$, um caso de coautoria e não de autoria mediata. $\mathrm{O}$ principal argumento manejado pela Corte Suprema foi o de que a teoria dos aparatos organizados de poder de Roxin não estava suficientemente "madura" e que não havia um reconhecimento generalizado de sua viabilidade prática na Alemanha, França, Itália ou Espanha $^{510}$. A Corte Suprema optou, assim, pela aplicação da teoria objetivo-formal para o descortinamento da autoria por compreendê-la doutrinariamente incorporada ao ordenamento jurídico argentino e menos "aberta" do que a teoria da autoria mediata de Claus Roxin ${ }^{511}$.

\subsubsection{A decisão do Tribunal Federal Alemão (Bundesgerichtshof - BGH) no caso dos homicídios praticados pelos guardas que vigiavam o muro de Berlim (1994)}

A primeira oportunidade que o Tribunal Federal Alemão aplicou a teoria da autoria mediata em razão de um aparato organizado de poder deu-se, curiosamente, depois de mais de trinta anos da criação da formulação por Claus Roxin, em 26 de julho de 1994. Na ocasião, o Bundesgerichtshof, ou apenas $B G H$, se debruçou sobre o seguinte caso: entre os anos de 1971 e 1989, sete pessoas tentaram fugir da antiga Alemanha Oriental (Deutsche Demokratische Republik - DDR) pulando o Muro de Berlim em direção à Alemanha Ociedental. Entretanto, ao proceder à travessia, esses cidadãos alemães foram alvejados mortalmente pelos guardas que realizavam a vigia do Muro $^{512}$.

\footnotetext{
${ }^{509}$ Três Magistrados argentinos se manifestaram em favor da autoria mediata, sendo que dois adotaram a tese nos exatos termos da construção teórica de Claus Roxin.

${ }^{510}$ FARALDO CABANA, Patricia. Responsabilidad penal del dirigente en estructuras jerárquicas: la autoría mediata con aparatos organizados de poder, cit., p. 40.

${ }^{511}$ Patricia Faraldo Cabana critica a mudança de direção da Corte Suprema argentina, asseverando que, ao adotar um conceito de autoria nos termos da teoria objetivo-formal, ela restringiu o instituto da autoria mediata estritamente aos casos em que o executor não ostenta liberdade, ou seja, age sob coação ou erro (Id. Ibid., p. 45-46). Com a mesma opinião crítica ao julgamento da Corte Suprema argentina: MEINI, Iván. El dominio de la organización en derecho penal, cit., p. 140-141.

${ }^{512}$ Existem referências doutrinárias acerca de um precedente do Tribunal Federal alemão $(B G H)$ anterior ao julgamento do dia 26 de julho de 1994 no qual se adotou a teoria de Claus Roxin. Trata-se de denominado "Caso do Rei dos Gatos" ou "Rei Felino", no qual o BGH, em 15 de setembro de 1988, reconheceu a autoria mediata em um caso em que o executor atuou com conhecimento reduzido do caráter ilícito de sua conduta, mas incorreu em erro de proibição evitável no cometimento do delito (ROXIN, Claus. Autoría y dominio del hecho en derecho penal, cit., p. 646; AMBOS, Kai. El caso alemán: imputación de crímenes de
} 
A acusação recaiu sobre os membros do Conselho de Defesa Nacional da Alemanha Oriental (Nationale Verteidigungsrat), órgão estatal central responsável exclusivamente pelas medidas de defesa e de segurança da antiga Alemanha, uma vez que ficou provada a existência de uma orientação generalizada no sentido de que qualquer "violação de fronteira" deveria ser impedida a qualquer custo, ainda que isso implicasse em morte do fugitivo que descumprisse essas determinações. O papel de vigília do Muro de Berlim ficava a cargo de militares treinados especialmente para essa finalidade, os quais, por sua vez, eram supervisionados por outras tropas de fronteira, também particularmente especializadas.

Também restou demonstrado que foram emanadas instruções de que eventuais falhas na fiscalização da travessia seriam rigorosamente apuradas, resultando em consequências para os soldados claudicantes. Havia um senso comum de que era mais importante assegurar obstar a "violação de fronteira" do que preservar a vida. A atuação expedita que impedisse a transposição da fronteira era saudada pelos superiores, ainda que ela acarretasse morte ou graves lesões corporais.

Em primeira instância, o Tribunal de Berlim condenou dois membros do Conselho de Defesa Nacional como indutores dos crimes de homicídio, sob o fundamento de que descabia autoria mediata em razão do pleno conhecimento dos soldados que, cumprindo as determinações do Conselho, mataram as pessoas que tencionaram transpor o Muro. Também foi descartada pela Corte de Berlim a possibilidade de coautoria, pois a jurisprudência indicava, à época, que somente poderia ser coautor aquele que realizava ao menos um elemento típico do delito ${ }^{513}$. Até a existência de um aparato organizado de poder de natureza estatal no âmbito da Alemanha Oriental foi rechaçada pelo Tribunal berlinense, entendendo-se, ao revés do que sucedeu no regime nazista, pela inexistência de um Estado

\footnotetext{
los subordinados al dirigente: un estudio comparado. Bogotá: Editorial Temis, 2008. p. 21; FARALDO CABANA, Patricia. Responsabilidad penal del dirigente en estructuras jerárquicas: la autoría mediata con aparatos organizados de poder, cit., p. 47 e ss.; PARIONA ARANA, Raúl. Autoría mediata por organización: consideraciones sobre su fundamentación y aplicación, cit., p. 38-40). Esse precedente, porém, conquanto tenha o mérito de delimitar a autoria mediata da indução, não foi considerado no histórico jurisprudencial por considerarmos que ele não apresentou - ou apresentou de modo demasiado superficial - uma hipótese genuína de aparato organizado de poder paraestatal, bem como porque ele não se utilizou da grande inovação de Roxin na caracterização da autoria mediata, qual seja, a consideração do autor imediato como sujeito plenamente responsável.

${ }^{513}$ FARALDO CABANA, Patricia. Responsabilidad penal del dirigente en estructuras jerárquicas: la autoría mediata con aparatos organizados de poder, cit., p. 65.
} 
de cunho totalitário. Essa circunstância fez com que não se vislumbrasse, na conduta dos Conselheiros, o domínio do fato, notadamente porque, segundo a Corte de Berlim, eles não dominavam nem o "se" e nem o "como" dos homicídios dolosos concretizados ${ }^{514}$.

O $B G H$, todavia, alterou esse panorama e condenou três membros do Conselho de Defesa Nacional da Alemanha Oriental (Heinz Kessler, Fritz Strelez e Hans Albrecht) como autores mediatos dos delitos de homicídio doloso consumado. A fundamentação do $B G H$ seguiu de perto os passos da construção teórica de Claus Roxin ${ }^{515}$ ao basear a condenação pela autoria mediata no fato de que efetivamente existia, no Estado da então Alemanha Oriental, um aparato organizado de poder erguido à margem do Direito. Sob essas circunstâncias, verificou-se a possibilidade concreta de utilização, por parte dos membros do Conselho, dos soldados que vigiavam a fronteira para $o$ cometimento de crimes, considerados autores imediatos, independentemente da responsabilidade penal e do conhecimento destes.

O $B G H$ ressaltou, em acréscimo, que os componentes do Conselho pertenciam a um grupo restrito cujas resoluções constituíam o pressuposto necessário das ordens que eram fielmente cumpridas pelos guardas de fronteira. Nessa condição, eles tinham conhecimento que as ordens seriam executadas, pois eram informados sobre o movimento de fronteira, sobre o número de vítimas e colocação de minas terrestres nas cercanias dos limites territoriais ${ }^{516}$. Em síntese: existia uma organização paraestatal com divisão de funções e hierarquia militar que proporcionava o controle dos atos perpetrados pelos subordinados ${ }^{517}$.

A decisão do $B G H$ foi confirmada em todos os seus termos posteriormente pelo Tribunal Constitucional Federal alemão (Bundesverfassungsgericht

\footnotetext{
${ }^{514}$ FARALDO CABANA, Patricia. Responsabilidad penal del dirigente en estructuras jerárquicas: la autoría mediata con aparatos organizados de poder, cit., p. 65.

${ }^{515}$ Preponderantemente, pois o $B H G$ também citou a doutrina de Friedrich-Christian Schroeder (PARIONA ARANA, Raúl. Autoría mediata por organización: consideraciones sobre su fundamentación y aplicación, cit., p. 41). Com crítica ao acolhimento das ideias de Schroeder: ROXIN, Claus. Autoría y dominio del hecho en derecho penal, cit., p. 654-655. Sobre a adoção da teoría de Roxin pelo BGH: AMBOS, Kai. El caso alemán: imputación de crímenes de los subordinados al dirigente: un estudio comparado, cit., p. 19-20.

${ }^{516}$ AMBOS, Kai. El caso alemán: imputación de crímenes de los subordinados al dirigente: un estudio comparado, cit., p. 23.

${ }^{517}$ FARALDO CABANA, Patricia. Responsabilidad penal del dirigente en estructuras jerárquicas: la autoría mediata con aparatos organizados de poder, cit., p. 71.
} 
ou BverfG) em $1997^{518}$.

A condenação empreendida pelo $B G H$ consubstanciou, sem dúvida, um marco histórico para a jurisprudência germânica, por representar o pioneiro caso concreto através do qual um órgão de cúpula do Poder Judiciário alemão teve a oportunidade de lançar mão, em termos amplos, da teoria da autoria mediata por intermédio de aparatos organizados de poder tal como concebida originariamente em 1963 por Claus Roxin.

Como aponta Patricia Faraldo Cabana ${ }^{519}$, o assentado na decisão do dia 26 de julho de 1994 pelo $B G H$ tem relevância tanto do ponto de vista político-jurídico, por alcançar pessoas que invariavelmente escapavam do raio de responsabilização penal justamente por ocupar os patamares mais altos das organizações estatais, como de um prisma exclusivamente jurídico, ao reconhecer uma terceira expressão de autoria mediata por domínio da vontade, com a particularidade de que aqui o autor imediato é plenamente responsável por seus atos.

Por fim, porém não menos importante, não se pode deixar de mencionar que o édito condenatório prolatado pelo $B G H$ merece ainda destaque dentre os diversos precedentes internacionais que se valeram da ideia de autoria mediata em estruturas de poder porque ele, pela primeira vez, admitiu a possibilidade de sua incidência na esfera das organizações empresariais.

De fato, para além das estruturas dissociadas do ordenamento jurídico (organizações paraestatais, organizações criminosas e organizações terroristas), o $B G H$ entendeu possível, ainda que em sede de obter dictum, que as pessoas que dirigem uma empresa sejam penalmente responsáveis como autores mediatos dos crimes cometidos pelos subordinados no contexto da organização ${ }^{520}$. E isso porque o ente empresarial, tal como as demais organizações, são conformadas hierarquicamente através da divisão de atribuições.

\footnotetext{
${ }^{518}$ FARALDO CABANA, Patricia. Responsabilidad penal del dirigente en estructuras jerárquicas: la autoría mediata con aparatos organizados de poder, cit., p. 72.

${ }^{519}$ Id. Ibid., p. 73.

${ }^{520}$ Id. Ibid., p. 70.
} 
Essa extensão interpretativa do $B G H$ suscitou profunda controvérsia dentro e fora da Alemanha, notadamente porque ela foi - e continua sendo até os dias de hoje criticada pelo próprio Claus $\operatorname{Roxin}^{521}$ e por outros doutrinadores, alemães ou não ${ }^{522}$. A (im)possibilidade de importar a teoria da autoria mediata por intermédio de aparatos organizados de poder para o ambiente empresarial será, todavia, abordada um pouco mais adiante, em um Capítulo específico, dada a sua relevância para o desdobramento do presente trabalho.

\subsubsection{A decisão do Tribunal Supremo Espanhol no Caso Mancha Real (1994)}

A decisão que costumeiramente é mencionada como o precedente judicial espanhol pioneiro - e talvez o único ${ }^{523}$ - na admissão da autoria mediata em um aparato organizado de poder foi emanada do Tribunal Supremo Espanhol em 02 de julho de 1994 por força do julgamento de uma acusação lançada contra o prefeito do distrito de Mancha Real em razão da produção de danos causados a diversos domicílios pertencentes a cidadãos de uma comunidade cigana.

No caso, os fatos se deram nos seguintes termos: na madrugada de 18 de maio de 1991, no interior de um bar chamado "El Cabrero", ocorreu uma briga entre membros da comunidade cigana e outros membros do distrito, que redundou na morte de uma pessoa e diversas outras lesionadas. Tomando conhecimento do desentendimento, um grupo de habitantes postulou justiça junto ao prefeito e conselheiros do distrito, cobrando esclarecimento dos fatos e a apuração das respectivas responsabilidades. Ao mesmo tempo, a população local passou a se concentrar nas imediações da prefeitura, tornando o clima

\footnotetext{
${ }^{521}$ ROXIN, Claus. Autoría y dominio del hecho en derecho penal, cit., p. 655-656.

${ }^{522}$ BOLEA BARDON, Carolina. Autoría mediata en derecho penal, cit., p. 389 e ss.

${ }^{523}$ Segundo Alicia Gil Gil, a escassez de julgados na Espanha sobre a aplicação da teoria da autoria mediata por aparatos organizados de poder se deve ao fato de os Tribunais espanhóis interpretam com extrema amplitude os institutos da coautoria e da indução e a possibilidade do partícipe sofrer a mesma pena cominada ao autor em caso de cooperação necessária. Outro aspecto mencionado por Alicia Gil Gil, além da cautela dos julgadores espanhóis na aplicação da teoria de Roxin, diz respeito à inexistência de uma situação fática que apresente todos os elementos necessários à consideração de uma estrutura organizacional como um verdadeiro aparato de poder (GIL GIL, Alicia. El caso español. Imputación de crímenes de los subordinados al dirigente: un estudio comparado. Bogotá: Editorial Temis, 2008. p. 100).
} 
tenso. Em face disso, foram realizadas reuniões ente o prefeito, os conselheiros distritais e agentes policiais, nas quais se decidiu pela expulsão das doze pessoas consideradas mais "indesejáveis" pela comunidade. Avisado que essa providência seria considerada ilegal ou mesmo inconstitucional, optou-se por pedir a esses doze indivíduos que abandonassem voluntariamente a localidade e pela convocação de uma manifestação popular, ocasião na qual o prefeito se manifestou à população em tom intimidatório, indicando o nome e os apelidos que as pessoas tidas como delinquentes eram conhecidas. $\mathrm{Na}$ mesma oportunidade, o prefeito prometeu que acabaria com os ciganos que causaram o homicídio e com todos os criminosos da população, convocando, em seguida, uma segunda manifestação para depois do enterro da vítima. Nessa segunda manifestação, posteriormente transformada em passeata, um grupo de manifestantes que passava na frente do local dos fatos ocorridos no dia 18 de maio de 1991, iniciou-se uma sequência de atos violentos dirigidos contra as habitações ciganas, quebrando portas e janelas.

Segundo o apurado, não ficou provado que o prefeito ou os conselheiros distritais viram ou mesmo consentiram com produção desses violentos eventos, mas apenas que eles tiveram conhecimento de algum incêndio produzido nas cercanias ao verificaram a existência de fumaça.

O prefeito foi condenado em primeira instância como autor de crimes contra a liberdade de domicílio e pela promoção de manifestação ilícita, além de ser considerado civilmente responsável, sendo condenado, por conseguinte, ao pagamento de indenização. Pela acusação assestada em razão dos danos produzidos nas residências ciganas, o prefeito foi absolvido. Em sede recursal, entretanto, o Tribunal Supremo espanhol entendeu que o prefeito agiu na condição de autor mediato do crime de dano, uma vez que ele detinha o domínio autêntico da decisão que impulsionou as condutas violentas desencadeadas contra a comunidade cigana. Ademais, entendeu a Corte espanhola que o prefeito se valeu de seu cargo para emitir ordens contrárias aos deveres de seu cargo, ostentado, assim, um superdomínio do fato dos autores imediatos, fundado na sua posição de autoridade pública $^{524}$. Sob esse contexto, o Tribunal Supremo equiparou a situação sob julgamento àquela do "autor por detrás do autor", caracterizada pela possibilidade de considerar a

${ }^{524}$ FARALDO CABANA, Patricia. Responsabilidad penal del dirigente en estructuras jerárquicas: la autoría mediata con aparatos organizados de poder, cit., p. 84-85. 
autoria a partir de determinadas situações nas quais o autor imediato da ação típica é plenamente responsável.

O mero relato dos fundamentos manejados pelo Tribunal Supremo espanhol para resolver o caso colocado sob julgamento deixa entrever que os pressupostos fáticos para a incidência da teoria da autoria mediata por intermédio de aparatos organizados de poder não se verificaram na hipótese concreta, tratando-se, no mínimo, de uma “questionável equiparação", para usar a expressão de Iván Meini ${ }^{525}$. Deveras, uma manifestação popular espontânea e publicamente convocada, por mais organizada que se afigure, não pode traduzir, sob qualquer aspecto, um aparato dotado de rigidez hierárquica $^{526}$ e funcionamento automático, com executores substituíveis ou intercambiáveis que atua apartado do ordenamento jurídico.

Daí a pertinente crítica de Patricia Faraldo Cabana no sentido de que o Tribunal espanhol simplesmente confundiu o domínio da organização com a cooperação psíquica do sujeito que, a partir de uma posição de autoridade, apoia e incentiva a atitude vingativa e violenta de uma multidão e que, com esse apoio, determina que os manifestantes incorram em erro sobre a existência de alguma causa de justificação de suas reprováveis condutas ${ }^{527}$.

\subsubsection{O caso Letelier: Chile (1993)}

Além do julgamento dos comandantes argentinos pelos crimes cometidos durante a ditadura militar, outro caso judicial de relevo ocorrido na América do Sul foi o processo criminal de membros do serviço secreto chileno (Dirección de Inteligencia Nacional chilena - DINA ${ }^{528}$ pelo homicídio do Embaixador Orlando Letelier del Solar ${ }^{529}$. A prova da acusação indicava que o então Coronel José Manuel Contreras Sepúlveda era

\footnotetext{
${ }^{525}$ MEINI, Iván. Responsabilidad penal del empresario por los hechos cometidos por sus subordinados, cit., p. 125.

${ }^{526}$ Id. Ibid., p. 126.

${ }^{527}$ FARALDO CABANA, Patricia. Responsabilidad penal del dirigente en estructuras jerárquicas: la autoría mediata con aparatos organizados de poder, cit., p. 85-86.

${ }^{528}$ Principal órgão chileno de repressão e persecução políticas durante os anos de 1974 e 1977 foi criado formalmente em 14 de junho de 1974.

${ }^{529}$ Letelier fora Embaixador Chileno nos Estados Unidos da América durante a presidência de Salvador Allende e Ministro das Relações Exteriores e de Defesa. Era um aguerrido opositor do governo de Pinochet; quando dos fatos encontrava-se em território norte-americano, sob exílio.
} 
Diretor da DINA e sobre ela exercia absoluto controle. Sob esse panorama, o Coronel Octavio Espinoza Bravo, subordinado a Contreras, comunicou a resolução do alto comando da DINA de matar Letelier a seu subalterno, Michael Townley, razão pela qual Townley viajou aos Estados Unidos da América com a finalidade de cumprir esse encargo. Letelier foi morto em Washington-DC por uma bomba colocada em seu veículo, em 21 de setembro de 1976.

A ação penal teve início na Justiça Militar em 1978 e tramitou lentamente até que, em 1991, seu processamento foi transferido para a Justiça Comum, ficando a cargo da Corte Suprema Chilena, sendo designado relator Adolfo Bañados Cuadra. Por intermédio da decisão prolatada em 12 de novembro de 1993, a Corte Suprema condenou os ex-membros da DINA como autores (coautores) mediatos do homicídio de Letelier, lastreando-se, para tanto, na comprovação de que existia um aparato organizado de poder na estrutura da DINA. A sentença chegou a indicar expressamente a doutrina de Claus Roxin para caracterizar Michael Townley como instrumento de José Manuel Contreras Sepúlveda e de Octavio Espinoza Bravo.

A fundamentação da Corte Chilena tem sido criticada, todavia, haja vista que ela baseara o automatismo do aparato de poder na concepção de que havia influência, autoridade e ascendência do Diretor da DINA sobre seus subordinados. Sucede que essa circunstância não acarreta a fungibilidade que Roxin exige para encontrar a autoria mediata, e se encontra vinculada muito mais à expectativa que o dirigente tem de que suas determinações serão executadas por aqueles que estão abaixo dele $\mathrm{e}^{530}$.

Analisando o caso concreto, Iván Meini, do mesmo modo crítico, entreviu na postura da Corte Chilena uma aproximação ou uma "equivalência valorativa" entre a forma como funcionava a DINA na época de Pinochet e a situação delineada no artigo 15.2 do Código Penal Chileno ${ }^{531}$, que considera autor aquele que força ou induz diretamente a

\footnotetext{
${ }^{530}$ MEINI, Iván. El dominio de la organización en derecho penal, cit., p. 143.

${ }^{531}$ Articulo 15. Se consideran autores: $1^{\circ}$. Los que toman parte en la ejecución del hecho, sea de una manera inmediata y directa, sea impidiendo o procurando impedir que se evite. $2^{\circ}$. Los que fuerzan o inducen directamente a otro a ejecutarlo. $3^{\circ}$. Los que, concertados para su ejecución, facilitan los medios con que se lleva a efecto el hecho o lo presencian sin tomar parte inmediata en él.
} 
outrem a executar o fato criminoso ${ }^{532}$.

De outro lado, para José Luis Guzmán a solução correta prescinde do domínio de vontade por aparatos organizados de poder e deveria ser extraída do instituto da participação, tratando Contreras como indutor e Espinoza como cúmplice, pois eles não realizaram atos de execução do homicídio de Orlando Letelier ${ }^{533}$.

\subsubsection{A jurisprudência peruana sobre os aparatos organizados de poder: nota prévia}

Constitui tarefa extremamente complexa, senão impossível, apontar, com precisão, qual ou quais precedentes judiciais lograram aplicar corretamente a formulação teórica criada por Claus Roxin em relação aos aparatos organizados de poder. Até porque o critério adotado para a confecção deste trabalho não pretendeu esgotar a análise de todas as decisões judiciais que, de algum modo, valeram-se dos ensinamentos de Claus Roxin na resolução dos mais variados problemas concretos espalhados pelo mundo, mas indicar os casos mais relevantes tratados - e testados - no âmbito doutrinário.

Não obstante, parece-nos fora de dúvida que os casos apreciados pelo Poder Judiciário peruano representam a contribuição prática mais significativa - ou a face mais acabada - à doutrina da autoria mediata em aparatos organizados de poder. Talvez porque o contexto político vivido recentemente por essa nação andina tenha ensejado o aparecimento das versões mais claras de aparatos organizados de poder, ou seja, da inserção de um Estado em outro Estado ou de um Estado paralelo de conteúdo terrorista, ambos forjados clandestinamente para atender prontamente as ordens de seu comandante. Talvez porque a doutrina penal peruana tem ganhado notável destaque na última década, muito em função do intenso intercâmbio acadêmico realizado com a Alemanha. Seja como for, a elaboração deste Capítulo não poderia prescindir da análise de três relevantes precedentes peruanos sobre o tema da autoria mediata: (i) o Caso do Falso Fiscal de 2007;

\footnotetext{
${ }^{532}$ MEINI, Iván. El dominio de la organización en derecho penal, cit., p. 144.

${ }^{533}$ GUZMÁN, José Luis. El caso chileno: imputación de crímenes de los subordinados al dirigente: un estudio comparado. Bogotá: Editorial Temis, 2008. p. 83.
} 
(ii) o Caso Abimael Guzmán do Sendero Luminoso, também de 2007 e, quiçá o mais importante, (iii) o Caso Fujimori/La Cantuta/Barrios Altos, julgado pela Sala Especial da Corte Suprema do Peru em 2009.

\subsubsection{A primeira decisão peruana: o Caso do Falso Fiscal (2007)}

O ex-presidente peruano Alberto Fujimori foi processado e condenado pela Suprema Corte de seu país em 11 de dezembro de 2007 porque determinou a um subordinado que ele usurpasse as funções de um membro do Ministério Público e, nessa condição, ingressasse ilicitamente em um domicílio. Ao fim do processo, a Corte Suprema peruana debateu a condição de Fujimori no cometimento de crime, se ele tinha agido como autor mediato em razão do domínio da organização ou como indutor. Prevaleceu a última posição e Fujimori foi condenado como indutor do crime de usurpação de função, muito embora a Corte tenha, contraditoriamente, referido expressamente - e de algum modo admitido - no corpo da decisão todos os requisitos necessários ao aparecimento do aparato organizado de poder. Essa decisão teve a inegável virtude de debater concretamente a possibilidade de incorporação, no ordenamento jurídico peruano, da autoria mediata em estruturas organizadas, mas recebeu críticas pela conclusão alcançada. Venire contra factum proprium, observou Raúl Pariona Arana $^{534}$, pois a Corte estabeleceu corretamente o pressuposto, mas dele não extraiu a derivação lógica que indicava Alberto Fujimori como autor mediato do crime de usurpação.

\subsubsection{A segunda decisão peruana: o Caso Abimael Guzmán. Líder do Sendero Luminoso (2007)}

Abimael Guzmán, líder do grupo terrorista peruano Sendero Luminoso, ocupava o cargo máximo de direção da organização, comandando o Comitê Central, o Comitê Permanente e o Escritório Político. Guzmán foi acusado de ordenar a prática de

\footnotetext{
${ }^{534}$ PARIONA ARANA, Raúl. Autoría mediata por organización: consideraciones sobre su fundamentación y aplicación, cit., p. 42.
} 
diversos atos terroristas consistentes em graves danos materiais e mortes, em especial por ter determinado o massacre contra sessenta e nove moradores do distrito de Santiago de Lucanamarca e arredores, no Perú, em 03 de abril de 1983. Os ataques foram produzidos com facas, machados e armas de fogo e recaiu indiscriminadamente sobre homens e mulheres. Entre os mortos, dezoito crianças, sendo que uma delas possuía apenas seis meses de idade.

Em primeira instância, Abimael Guzmán foi condenado à prisão perpétua como autor mediato porque ficou provado que ele dirigia, como líder supremo, todo o aparato da organização terrorista e, nessa condição, emitia ordens para a execução de ações armadas por intermédio de outros dirigentes do Comitê Central. A Sala Penal Nacional $(S P N)$ prolatou sua decisão em 13 de outubro de 2006 apoiando-se pela primeira vez na teoria da autoria mediata através de aparatos organizados de poder de Claus $\operatorname{Roxin}^{535}$. Nessa oportunidade, a $S P N$ cotejou todos os pressupostos teóricos do aparato com os elementos fáticos apresentados pelo caso concreto, concluindo que o Sendero Luminoso apresentava-se como um verdadeiro aparato de poder (i) criado à margem do Direito, (ii) hierarquicamente estabelecido com (iii) executores (autores imediatos) fungíveis, e que ele era comandado por Guzmán ${ }^{536}$.

A condenação de Abimael Guzmán como autor mediato do massacre de Lucanamarca foi confirmada pela Segunda Sala Penal Transitória da Corte Suprema de Justiça em 14 de dezembro de 2007. A Corte Suprema de Justiça ratificou, por maioria de $\operatorname{votos}^{537}$, a adoção da teoria do domínio de vontade por aparatos organizados de poder de Claus Roxin pela primeira instância, assentando, em acréscimo, a compatibilidade dessa categoria dogmática com o ordenamento jurídico peruano. Além disso, a Corte indicou que os aparatos de poder podem se constituir em ambientes diversos da esfera estatal, como ocorre, por exemplo, com as organizações criminosas, desde que se verifique a presença de uma estrutura altamente hierarquizada e a atuação de executores substituíveis em razão da verticalidade. A Corte Suprema de Justiça também assentou a possibilidade de autoria

\footnotetext{
${ }^{535}$ Nesse sentido: PARIONA ARANA, Raúl. Autoría mediata por organización: consideraciones sobre su fundamentación y aplicación, cit., p. 42.

${ }^{536}$ MEINI, Iván. El dominio de la organización en derecho penal, cit., p. 153. Também: PARIONA ARANA, Raúl. Autoría mediata por organización: consideraciones sobre su fundamentación y aplicación, cit., p. 43.

${ }^{537} \mathrm{O}$ magistrado Villa Stein votou vencido sustentando a ocorrência de coautoria.
} 
mediata ainda que o autor imediato (executor) se afigure, no momento do cometimento da conduta, plenamente responsável ${ }^{538}$.

Por fim, para além da inserção das balizas dogmáticas visando o reconhecimento da teoria da autoria mediata através do controle de aparatos organizados de poder, ao decidir o caso Abimael Guzmán a Corte Suprema de Justiça peruana transcendeu a importância do seu próprio julgamento e pavimentou o caminho que tornou possível a apreciação do caso mais notório de domínio da organização: o Caso Fujimori/La Cantuta/Barrios Altos, julgado em 07 de abril de 2009 pela Sala Penal Especial da Corte Suprema do Perú.

\subsubsection{A terceira decisão peruana: o Caso Fujimori/La Cantuta/Barrios Altos (2009)}

O ex-presidente peruano Alberto Fujimori foi processado pelo Ministério Público (Procuradoria-Geral) porque, segundo a acusação, na condição de Presidente da República e sob o argumento de desmantelar atividades terroristas que assolavam o país, ele concebeu uma estrutura legal específica visando à criação de um Sistema de Inteligência Nacional (SIN) cujo chefe era designado pelo próprio Presidente da República. Nessa condição, Fujimori nomeou como dirigente do SIN Vladimiro Montesinos Torres, embora centralizando na sua pessoa as atividades de defesa nacional e se arvorando na condição de decidir e pessoalmente lidar com a política contra o eixo subversivo terrorista.

Segundo o Ministério Público, Fujimori apresentou dois métodos ou estratégias: (a) uma oficial, visível e convencional, a qual era relatada nos discursos oficiais, mensagens públicas e documentos, e que estava em conformidade com o ordenamento jurídico constitucional e legal; e (b) outra em segredo, de caráter clandestino, sem vínculo legal, conhecida informalmente como "guerra de baixa intensidade", que buscava a eliminação física de pessoas suspeitas de subversão, ao abrigo da qual se

\footnotetext{
${ }^{538}$ MEINI, Iván. El dominio de la organización en derecho penal, cit., p. 160. Meini, porém, tece duras críticas às conclusões da Corte peruana, não pelo resultado em si, que ele considera correto, mas pela ausência de motivação suficiente das conclusões judiciais (Id. Ibid., p. 163 e ss.).
} 
desenvolveu as atividades do Grupo Colina, composto de membros do Exército peruano, que entre outras coisas, perpetraram os crimes de Barrios Altos e La Cantuta. O Grupo Colina contou com o apoio de líderes militares, supervisionados por Montesinos, e com o aparelho organizado de poder. A acusação do Ministério Público foi lastreada em quatro fatos $^{539}$.

$1^{\circ}$ Fato (Caso Barrios Altos): na execução da política de "guerra suja" aplicada por Fujimori, no dia 3 de novembro de 1991, por volta de 22h30min, os membros do Grupo Colina, cobrindo os rostos com máscaras e usando armas de guerra com silenciadores, invadiram uma casa localizada em Jirón Huanta, n. ${ }^{\circ}$ 840, Barrios Altos, determinando que as pessoas que lá estavam a se jogarem ao chão e, em seguida, alvejaram-nas com disparos de arma de fogo de alto calibre (pistolas nove milímetros), sem qualquer possibilidade de defesa ou probabilidade de fuga das vítimas. Nesta oportunidade, quinze pessoas foram mortas, enquanto quatro sofreram lesões graves. Essa operação foi comandada por Santiago Martin Rivas e sua execução foi precedida de um plano cuidadosamente concebido, pois antes do ataque o local dos fatos foi vigiado por agentes de inteligência do Exército. A ação do Grupo Colina foi apoiada pelos órgãos de inteligência do Estado peruano, que forneceram recursos materiais (veículos oficiais) e humanos.

$2^{o}$ Fato (Caso La Cantuta): Fujimori também foi acusado em razão de fatos cometidos pelo Grupo Colina em 18 de julho de 1992, na Universidade Nacional de Educação "Enrique Guzmán y Valle", em La Cantuta. Segundo o Ministério Público, um dia antes o comandante geral do Exército Nicolás Hermoza Ríos se comunicou com o Luis Augusto Pérez Documet, chefe da Divisão das Forças Especiais, sob cujo comando se encontrava a Base de Ação Cívica instalada na mencionada Universidade desde maio de 1991 e lhe ordenou que prestasse apoio ao General Rivero Lazo, Diretor de um órgão de inteligência. Na madrugada do dia 18 de julho de 1992, os membros do Grupo Colina ingressaram na Universidade a bordo de duas caminhonetes portando capuzes e armas de fogo munidas com silenciadores. Ato contínuo, eles se dirigiram aos dormitórios da Universidade e, após identificar nove estudantes e o professor Hugo Muñoz Sánchez,

\footnotetext{
${ }^{539}$ Cf. $42^{\circ}$ do acórdão (EXP. No A.V. $19-2001$ ).
} 
separaram-nos do grupo e os conduziram a bordo dos veículos até a altura do quilometro um e meio da estrada Ramiro Prialé, onde todos foram mortos, enterrados e incinerados. Posteriormente, outros membros do agrupamento Colina receberam informações que os restos mortais das vítimas não estavam devidamente enterrados, de modo que ainda foram desenterrados alguns cadáveres, transportados e novamente enterrados clandestinamente em outra localidade.

$3^{\circ}$ Fato (Caso Porões do SIE): com o conhecimento e a aprovação de Fujimori, membros do serviço de inteligência, depois do golpe de Estado realizado em 05 de abril de 1992, destinaram os porões do SIE para que suas celas fossem ocupadas por diversas pessoas ilegalmente presas, particularmente supostos terroristas. A cadeia de comando, segundo a acusação, era formada por Montesinos, como chefe de fato do SIN, Hermoza Ríos, chefe do Comando Conjunto das Forças Armadas, e Alberto Pinto Cárdenas, Chefe do SIE. Sob esse contexto, o jornalista Gustavo Andrés Gorriti Ellenbogen foi retirado do seu domicílio às três horas da madrugada do dia 06 de abril de 1992 e conduzido ao SIE, onde foi recebido pelo Coronel Alberto Pinto Cárdenas ali permanecendo em uma das celas do porão até o dia seguinte. Posteriormente, Gustavo Andrés foi transferido para a sede do Departamento de Segurança do Estado, localizado na Prefeitura de Lima.

$4^{o}$ Fato (Caso sequestro do empresário Samuel Dyer Ampudia): o empresário Samuel Edward Dyer Ampudia foi detido no aeroporto Internacional Jorge Chávez pelo Coronel Carlos Domínguez Solís, Diretor Nacional de Contrainteligência do SIN. Samuel Edward foi, então, conduzido ao SIE e preso sob a acusação de tomar parte na prática de delito terrorista, onde permaneceu isolado até o dia 05 de agosto de 1992. A acusação era inexistente e, para dar aparência de legalidade à detenção, o Chefe do SIE, Coronel Pinto Cárdenas, que recebeu Samuel Edward por ordem de Montesino e lhe fez saber que a determinação provinha de Alberto Fujimori, se comunicou com Antonio Ketín para encetar uma investigação pela prática de atividade terrorista, o que efetivamente ocorreu em 30 de julho de 1992. Ao final da investigação, constatou-se que Samuel Ampudia não tinha qualquer relação com atividades terroristas. Diante desses fatos, o Ministério Público qualificou as condutas relacionadas ao Caso La Cantuta e Barrios Altos 
como homicídio e lesões corporais graves. Nos casos Porões do SIE e Samuel Dyer Ampudia, considerou-se a perpetração do delito de sequestro em sua forma agravada.

O domínio da organização por Alberto Fujimori pelo Ministério Público. O Ministério Público sustentou que Alberto Fujimori praticou todas as infrações penais como autor mediato por domínio da organização. Especificamente no que tange ao Grupo Colina, aduziu a Procuradoria Geral que Fujimori atuava no ápice de sua estrutura e que ele traçou e decidiu uma política de Estado antissubversiva adotando métodos de guerra de "baixa intensidade" voltados à eliminação de inimigos, cujas ordens, em virtude de sua hierarquia e domínio da organização, nos casos de Barrios Altos e La Cantuta, se cumpriram completamente. Com efeito, asseverou a acusação que Fujimori detinha o domínio do fato em relação aos executores imediatos por força do domínio da organização criminal. O grupo Colina, a seu turno, somente tinha a capacidade de decidir a execução das ações delitivas através de Vladimiro Montesinos Torres, que decidia - e era esse seu papel - se levada a cabo ou não uma determinada atividade ou "operação especial", concebida para a eliminação física daqueles que arbitrariamente eram considerados “supostos terroristas". Fujimori sabia que suas ordens, pela relação de subordinação de seus membros, seriam cumpridas. Similar situação ocorreu no sequestro do jornalista Gustavo Andrés Gorriti Ellenbogen e do empresário Samuel Dyer Ampudia, completamente alheios a qualquer atividade terrorista, haja vista que Alberto Fujimori ostentava função de domínio sobre os aparatos estatais de inteligência em razão de sua máxima hierarquia e da predisposição dos integrantes do mencionado aparato de poder para executar suas ordens - notadamente em virtude da estrutura hierarquia militar que integravam $^{540}$.

O julgamento da Sala Penal Especial da Corte Suprema de Justiça do Perú (07 de abril de 2009). Após o trâmite de um processo penal que cumpriu rigorosamente todos os pressupostos do due processo of $l a w^{541}$, o ex-presidente Alberto Fujimori foi condenado a uma pena privativa de liberdade de vinte e cinco anos, posteriormente confirmada pela Primeira Sala Transitória da Corte Suprema de Justiça (em 30 de dezembro de 2009). A decisão peruana foi considerada histórica sob os mais variados

\footnotetext{
${ }^{540} \mathrm{Cf} .43^{\circ}$ e $44^{\circ}$ parágrafos do acórdão (EXP. N ${ }^{\circ}$ A.V. 19 - 2001).

${ }^{541}$ CARO CORIA, Dino Carlos. Sobre la punición del ex presidente Alberto Fujimori, cit., p. 145.
} 
aspectos por Claus Roxin ${ }^{542}$, Kai Ambos ${ }^{543}$, Iván Meini ${ }^{544}$ e Raúl Pariona Arana ${ }^{545}$. De fato, o decisum é singular porque representou o acolhimento, em termos claros e suficientemente motivados, da teoria formulada por Claus Roxin - com as observações de Friedrich-Christian Schroeder sobre a predisposição do executor para o cometimento do fato -, bem assim porque indicou, de modo extremamente pedagógico, que nenhuma pessoa encontra-se isenta de ser responsabilizada penalmente por delitos cometidos, ainda que ocupe os cargos públicos mais elevados de uma nação. Deveras, ambas as instâncias basearam a responsabilidade penal de Fujimori na sua condição de autor mediato em virtude do controle de um aparato organizado de poder, na esteira da doutrina desenvolvida prioritariamente pelo professor alemão Claus Roxin ${ }^{546}$. Com efeito, após estabelecer que existem três formas de autoria mediata, sendo que em todas elas o agente atua ou intervém dominando a vontade do autor imediato ou material (domínio por erro, domínio por coação e domínio em razão de aparatos organizados de poder $)^{547}$ e realizar um breve panorama sobre as posições doutrinárias discrepantes ${ }^{548}$, a Corte de Justiça peruana assentou que Alberto Fujimori poderia ser condenado como autor mediato dos quatro fatos imputados pelo Ministério Público, pois todos os pressupostos e requisitos da existência do aparato de poder quedaram suficientemente demonstrados durante a instrução processual ${ }^{549}$.

Pressupostos e requisitos do aparato organizado de poder: a Corte de Justiça do Perú dividiu a análise dos pressupostos do aparato de poder em dois grupos: (i) pressuposto geral, relacionado à existência da organização ${ }^{550}$, e (ii) pressupostos específicos e seus requisitos ${ }^{551}$. Neste segundo grupo o acórdão estipulou que a identificação das organizações hierárquicas que consubstanciam aparatos de poder está

\footnotetext{
${ }^{542}$ ROXIN, Claus. Apuntes sobre la Sentencia-Fujimori de la Corte Suprema del Perú, cit., p. 93.

${ }^{543}$ AMBOS, Kai. La autoría mediata por organización en la sentencia contra Fujimori: transfondos políticos y jurídicos de la sentencia contra el ex presidente peruano Alberto Fujimori, cit., p. 87.

${ }^{544}$ MEINI, Iván. El dominio de la organización de Fujimori. Comentarios a la sentencia de 7 de abril de 2009 (Exp. A.V. 19-2001). In: AMBOS, Kai; MEINI, Iván (Eds.). La autoría mediata: el caso Fujimori. LimaPeru: Ara Editores, 2010. p. 213.

${ }^{545}$ AMBOS, Kai. La autoría mediata por organización en la sentencia contra Fujimori: transfondos políticos y jurídicos de la sentencia contra el ex presidente peruano Alberto Fujimori, cit., p. 233.

${ }^{546}$ Cf. parágrafos $718^{\circ}$ e seguintes do acórdão (EXP. No A.V. $\left.19-2001\right)$.

${ }^{547}$ Cf. parágrafo $720^{\circ}$ do acórdão (EXP. No A.V. $\left.19-2001\right)$.

${ }^{548}$ Cf. parágrafo $720^{\circ}$ do acórdão (EXP. No A.V. $\left.19-2001\right)$.

${ }^{549}$ Cf. parágrafo $745^{\circ}$ do acórdão (EXP. No A.V. $\left.19-2001\right)$.

${ }^{550}$ Cf. parágrafo $726^{\circ}$ do acórdão (EXP. N ${ }^{\circ}$ A.V. $19-2001$ ).

${ }^{551}$ Cf. parágrafo $727^{\circ}$ do acórdão (EXP. No A.V. $19-2001$ ).
} 
condicionada à demonstração de quatro pressupostos e requisitos funcionais, a saber: (ii.i) o poder de mando; (ii.ii) a desvinculação da organização do ordenamento jurídico; (ii.iii) a fungibilidade do executor imediato; e (ii.iv) a elevada disponibilidade do executor para o fato $^{552}$. Ademais, a Corte aduziu que os pressupostos específicos podem ser examinados em dois níveis diversos ${ }^{553}$ : (i) o primeiro, de caráter objetivo, compreende (i.i) o poder de mando e (i.ii) a desvinculação do ordenamento jurídico do aparato de poder; (ii) o segundo, de caráter subjetivo, onde estão localizadas a (ii.i) fungibilidade do executor direto e (ii.ii) a sua elevada disposição para a realização do fato. Passemos, pois, à análise individualizada de cada requisito vislumbrado no acórdão da Sala Especial da Corte Suprema de Justiça peruana.

(i.i) O poder de mando: para a Corte de Justiça peruana, significa a capacidade do nível estratégico superior, ou seja, do homem que está por trás, de emitir ordens e atribuir funções no seio da organização que lhe é subordinada. Esta capacidade pode ser adquirida ou conferida em atenção a uma posição de autoridade, liderança ou ascendência derivadas de fatores políticos, ideológicos, sociais, religiosos, culturais, econômicos ou de natureza similar. Esse poder de mando ou de direção do aparato se manifesta concretamente por intermédio de ordens emanadas expressa ou implicitamente, as quais serão cumpridas em razão do automatismo outorgado pela própria constituição funcional do aparato. Dispensa-se, assim, a coação ou o erro dos potenciais executores: o poder de comando emerge da integração da pessoa interposta ou executor direto ao aparato organizado de poder ${ }^{554}$. No interior do aparato podem ser vislumbradas duas formas através das quais o poder de mando pode se expressar: (i) do nível superior estratégico até os níveis intermediários ou operativos e (ii) do nível intermediário até os executores materiais. O poder de mando, portanto, é exercido em sentido vertical, de cima para baixo, e será distinto dentro de cada patamar, uma vez que quem se encontra na cúspide da organização hierárquica tem um domínio total do aparato, enquanto que quem se encontra no nível intermediário tem somente a possibilidade de ditar ordens no setor da organização

\footnotetext{
${ }^{552}$ Cf. parágrafo $727^{\circ}$ do acórdão (EXP. N ${ }^{\circ}$ A.V. 19 - 2001). Para a Corte Suprema de Justiça esses requisitos devem ser analisados de maneira conjunta, e sua valoração deve levar em consideração cada caso concreto, evitando-se, assim, uma "visão parcial" do funcionamento do aparato.

${ }^{553}$ Cf. parágrafo $728^{\circ}$ do acórdão (EXP. No A.V. $\left.19-2001\right)$.

${ }^{554}$ Cf. parágrafo $729^{\circ}$ do acórdão (EXP. No A.V. 19 - 2001).
} 
sob sua atribuição ${ }^{555}$. As ordens emanadas por aqueles que ostentam poder de mando podem ser verbais ou escritas, ou mesmo manifestadas através de sinais ou gestos ${ }^{556}$. Segundo a Corte de Justiça peruana, podem ser ordens formais, isto é, expressadas por intermédio de disposições, diretivas, regulamentos, ou podem ser ordens por sua efetividade material, como senhas, expressões, gesticulações, ações concretas, ou expressões afins de natureza diversa ${ }^{557}$. As ordens formalizadas são comumente utilizadas pelos aparatos que surgiram em conformidade com o ordenamento jurídico, mas que, no decorrer de suas atividades, apartaram-se do regime formal e legítimo. Nada obstante, a Corte peruana apontou que, pelas experiências judiciais conhecidas em matéria de aparatos organizados de poder de natureza ou origem estatal, afigura-se comum que não se registre em nenhuma disposição ou documento a ordem de conteúdo ilegal, pois o importante é o poder concreto, efetivo e real, que se exerce pelo nível de comando dentro da organização, bem como que os subordinados a reconheçam como tal ${ }^{558}$.

O poder de mando de Alberto Fujimori: no caso concreto, a Corte Suprema de Justiça entendeu provado o poder de mando de Alberto Fujimori sobre o aparato de poder que proporcionou o cometimento dos crimes de homicídio, lesões corporais e de sequestro, estabelecendo que Fujimori ocupava a posição mais alta no nível estratégico do Estado peruano em geral e do Sistema de Defesa Nacional em particular. Dessa posição ele exerceu ostensivamente o poder de mando para a condução política e militar, direcionando as estratégias de enfretamento contra as organizações subversivas terroristas que atuavam no país desde o início da década de oitenta ${ }^{559}$. No ambiente da organização comandada por Fujimori visava-se a eliminação de supostos terroristas e seus órgãos ou bases de apoio ${ }^{560}$.

(i.ii) A desvinculação do ordenamento jurídico do aparato de poder: esse segundo requisito está atrelado, de acordo com a decisão peruana, à ideia de que o aparato deve estar dissociado do Direito, este compreendido como sistema ou ordenamento

\footnotetext{
${ }^{555}$ Cf. parágrafo $730^{\circ}$ do acórdão (EXP. No A.V. 19 - 2001). A Corte de Justiça, aliás, expressou no acórdão aquilo que parece intuitivo: quanto mais alto o patamar ocupado pelo sujeito dentro do aparato, maior a sua

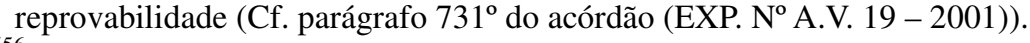

${ }^{556}$ Cf. parágrafo $732^{\circ}$ do acórdão (EXP. No A.V. $\left.19-2001\right)$.

${ }^{557}$ Cf. parágrafo $732^{\circ}$ do acórdão (EXP. No A.V. 19 - 2001).

${ }^{558} \mathrm{Cf}$. parágrafo $732^{\circ} .2$ do acórdão (EXP. No A.V. $\left.19-2001\right)$.

${ }^{559} \mathrm{Cf}$. parágrafo $745^{\circ} .1$. do acórdão (EXP. No A.V. $\left.19-2001\right)$.

${ }^{560}$ Cf. parágrafo $745^{\circ}$ do acórdão (EXP. No A.V. 19 - 2001).
} 
jurídico representado por um conjunto coordenado de normas gerais e positivas que regulam a vida social. Para a Corte Suprema, o conceito de Direito deve ser extraído tanto dos preceitos do sistema jurídico interno ou nacional, como do sistema de Direito Internacional $^{561}$. O exame desse requisito seguiu de perto a linha teórica desenvolvida por Claus Roxin ${ }^{562}$, concluindo a decisão, também na esteira de Roxin, que a dissociação ou desvinculação do Direito ocorre não apenas em delitos cometidos por órgãos do Estado ou aparatos do poder estatal, mas também nas organizações criminosas e em muitas formas de aparecimento do terrorismo $^{563}$. Não obstante, no que tange ao aparato organizado estatal, a Corte peruana assentou que a dissociação do Direito pode ser concretizada de duas maneiras. A primeira, quando o nível superior estratégico do Estado decide apartar-se por completo do Direito e criar um sistema normativo totalmente diferente que não é reconhecido nem aceito pelo Direito Internacional que expressa ou encobre a comissão de crimes graves. A segunda maneira, quando o nível superior estratégico do poder estatal se distancia paulatinamente do ordenamento jurídico, isto é, no início a dissociação ocorre apenas para a realização de determinados fatos puníveis, mas, logo depois, são perpetrados atos sistemáticos cada vez mais frequentes, bem assim condutas destinadas a anular, desnaturar ou substituir distorcidamente os diferentes âmbitos e competências que configuram os estamentos oficiais, legais e de controle do Estado. Essa segunda forma, acrescenta a decisão, revela-se mais grave porque se cobre o aparato com uma aparência de legalidade e se pretende, com isso, criar um sistema normativo alternativo àquele legalmente vigente, aproveitando-se justamente das suas formas e estruturas para o cometimento de crimes graves ${ }^{564}$.

Analisando o caso concreto, a Corte peruana entendeu provada a circunstância de Alberto Fujimori ter criado uma estrutura clandestina dissociada do Direito. Especificamente em relação aos crimes levados a efeito no Caso La Cantuta e Barrios Altos, assinalou o Poder Judiciário que os homicídios e as lesões corporais graves decorreram de ações executivas planejadas pelo órgão de inteligência formado com notória ilegalidade e clandestinidade e que ele, a seu turno, se apartou tanto do ordenamento

\footnotetext{
${ }^{561}$ Cf. parágrafo $733^{\circ}$ do acórdão (EXP. No A.V. $\left.19-2001\right)$.

${ }^{562} \mathrm{Cf}$. parágrafo $734^{\circ}$ do acórdão (EXP. No A.V. 19 - 2001).

${ }^{563}$ Id. Ibid.

${ }^{564}$ Cf. parágrafo $735^{\circ} .4$ do acórdão (EXP. N N A.V. 19 - 2001).
} 
jurídico nacional como do ordenamento jurídico internacional ${ }^{565}$.

Pressupostos e Requisitos Subjetivos: (ii.i) a fungibilidade do executor direto: na dicção da Corte Suprema peruana a fungibilidade do executor consiste no fato dele poder ser intercambiado ou substituído pelo nível estratégico superior na consecução do desígnio criminoso do aparato. Aqui também a decisão peruana alinhou-se à Claus Roxin, chegando a citar a célebre ilustração do professor alemão, desenhada no sentido de que o executor funciona, no interior do aparato, como uma espécie de "rodinha cambiável na máquina do poder", ou uma "engrenagem" que pode ser substituída a qualquer tempo, embora ocupe um lugar central na materialização dos acontecimentos ilícitos ${ }^{566}$. A Corte admitiu duas classes de fungibilidade, uma negativa, outra positiva.

Fungibilidade negativa corresponde ao conceito tradicional empregado por Roxin, e diz respeito ao fato de o executor não se apresentar como pessoa livre e responsável, mas como uma figura anônima e substituível. Em termos concretos: a eventual recusa do executor em cometer a conduta criminosa planejada pela organização não impedirá que ela seja realizada, pois haverá outra pessoa que o fará em seu lugar sem qualquer prejuízo para a atividade do aparato de $\operatorname{poder}^{567}$.

De outro lado, cogitar-se-á de fungibilidade positiva a partir da existência de uma pluralidade de executores potenciais na estrutura do aparato de poder. Essa circunstância confere, na visão da Corte peruana, maior garantia de cumprimento da ordem criminosa emitida pelo nível estratégico superior ${ }^{568}$. Mais adiante, a decisão incursiona sobre a discussão dogmática que cerca a fungibilidade do executor para afirmar que esse requisito deve ser interpretado em conjunto com outro, qual seja, a predisposição do agente para a realização do fato, criado por Friedrich-Christian Schroeder, em uma operação que ela denomina de "integradora" ${ }^{569}$, o que significa dizer, concretamente, que a fungibilidade e a elevada disposição para a realização do fato não devem ser apreciadas como pressupostos

\footnotetext{
${ }^{565}$ Cf. parágrafo $745^{\circ} .6$ do acórdão (EXP. No A.V. 19 - 2001).

${ }^{566}$ Cf. parágrafo $737^{\circ}$ do acórdão (EXP. No A.V. $\left.19-2001\right)$.

${ }^{567}$ Cf. parágrafo $738^{\circ}$ do acórdão (EXP. No A.V. $\left.19-2001\right)$.

${ }^{568}$ Cf. parágrafo $738^{\circ} .3$ do acórdão (EXP. No A.V. $\left.19-2001\right)$.

${ }^{569} \mathrm{Cf}$. parágrafo $739^{\circ} .5$ do acórdão (EXP. N ${ }^{\circ}$ A.V. $\left.19-2001\right)$.
} 
excludentes e muito menos incompatíveis entre si $^{570}$.

Sobre a figura particular de Alberto Fujimori, a Corte de Justiça peruana asseverou que em todos os delitos a condição fungível dos executores e a disposição ao fato, aliada à inexistência de relação direta nem horizontal com Fujimori possibilitam afirmar a sua posição de autor mediato como ente central com poder hierárquico de domínio sobre o aparato de poder, cujo automatismo conhecia e podia controlar através de comandados intermediários ${ }^{571}$.

(ii.ii) A elevada disposição do executor para a realização do fato: trata-se da predisposição psicológica do executor à realização da ordem que acarreta $o$ cometimento do crime. Esse requisito, conforme aludiu a Corte de Justiça, não pertencia à originária formulação da teoria da autoria mediata por aparatos organizados de poder de Claus Roxin, mas foi por ele acrescentado em suas manifestações mais recentes, na esteira do que vinha sustentando, desde 1965, Friedrich-Christian Schroeder ${ }^{572}$. O acórdão peruano indica que não existe acordo no plano doutrinário ou jurisprudencial acerca do caráter condicional ou incondicional dessa predisposição do executor material, conquanto exista consenso no reconhecimento que esta característica aparece ligada à posição e integração do executor com o aparato de poder, com seus órgãos de direção e com os objetivos que ambos representam e desenvolvem ${ }^{573}$.

\subsection{Aparato organizado de poder e as organizações empresariais}

\subsubsection{Introdução: a organização empresarial como aparato de poder}

Ao reconhecer a responsabilidade penal dos membros do Conselho de Defesa Nacional da antiga Alemanha Oriental pelos crimes praticados pelos guardas do muro de Berlim em 1994, a $5^{\text {a }}$ Turma do Tribunal Federal alemão $(B G H)$ reconheceu,

\footnotetext{
${ }^{570}$ Cf. parágrafo $739^{\circ} .4$ do acórdão (EXP. No A.V. 19 - 2001).

${ }^{571}$ Cf. parágrafo $745^{\circ} .8$ do acórdão (EXP. No A.V. $\left.19-2001\right)$.

${ }^{572}$ Cf. parágrafo $740^{\circ}$ do acórdão (EXP. № A.V. 19 - 2001).

${ }^{573} \mathrm{Cf}$. parágrafo $741^{\circ}$ do acórdão (EXP. No A.V. $19-2001$ ).
} 
conquanto que em sede de obter dictum, a possibilidade de aplicação da teoria do domínio de vontade mediante aparato organizado de poder para resolver o problema da responsabilidade no funcionamento de empresas. O $B G H$, todavia, foi além daquilo que preconizava - e preconiza até hoje - o próprio Roxin, criador da formulação teórica ${ }^{574}$.

Essa decisão, obviamente, ensejou viva controvérsia no meio acadêmico, pois Roxin tem defendido desde o início que o fato fundamental a ser considerado é o de que a sociedade empresária atua dentro dos limites do Direito, isto é, não existe uma dissociação ao Direito como sucede com os crimes praticados pelo Estado, os delitos de terrorismo e os casos de criminalidade organizada ${ }^{575}$ e, dessa forma, não se pode conceber a existência de um verdadeiro aparato de poder. Faltaria às empresas, proclama Roxin, o requisito da fungibilidade, pois o empregado da sociedade não está submetido às ordens de conteúdo manifestamente ilegal, podendo, em consequência, recusar o seu cumprimento ${ }^{576}$.

Além disso, tivemos a oportunidade de verificar que o requisito da dissociação do Direito, tido como imprescindível para a existência do aparato organizado de poder por Claus Roxin, tem sido colocado à prova pela doutrina, fato que, evidentemente, confere uma potencial extensão da teoria a outras instâncias organizadas.

Some-se a isso o fato de que as empresas mais modernas e sofisticadas apresentam características muito similares aos aparatos organizados de poder (pluralidade de membros, estrutura hierárquica, divisão de funções e funcionários substituíveis), conquanto atuem de forma juridicamente ordenada e funcionem automaticamente, pois os processos de produção encontram-se devidamente formalizados ${ }^{577}$.

\footnotetext{
${ }^{574}$ ROXIN, Claus. Autoría y dominio del hecho en derecho penal, cit., p. 729.

${ }^{575}$ FARALDO CABANA, Patricia. Responsabilidad penal del dirigente en estructuras jerárquicas: la autoría mediata con aparatos organizados de poder, cit., p. 305.

${ }^{576}$ ROXIN, Claus. Autoria mediata por meio de domínio de organização, cit., p. 336. Roxin resume sua opinião com um ilustrativo exemplo: "quando, por exemplo, em uma empresa, que atua dentro dos limites do ordenamento jurídico ao realizar seus negócios, um diretor de uma seção exorta um empregado a falsificar um documento, na hipótese do crime ser cometido, este dirigente será apenas um instigador do fato típico, cometido pelo empregado (este sim, na qualidade de autor). Em face de uma organização que trabalha dentro do Direito, deve-se esperar que as ordens ilícitas não sejam obedecidas, vide o exemplo dos estatutos dos servidores públicos com suas disposições expressas quanto à conduta dos agentes públicos" (Id. Ibid., p. 337).

${ }^{577}$ MARÍN DE ESPINOSA CEBALLOS, Elena B. Criminalidad de empresa: la responsabilidad penal en las estructuras jerárquicamente organizadas, cit., p. 68.
} 
Mais: a dinâmica da criminalidade moderna tem aproximado as organizações criminosas - inegáveis aparatos organizados de poder - das atividades desempenhadas pelas organizações empresariais, cuja essência consiste na produção de bens e serviços não proibidos por lei e na busca lícita de benefícios econômicos.

Esse panorama impõe que analisemos a possibilidade de "transplantar" a teoria do domínio de vontade por aparatos organizados de poder desenvolvida originariamente somente para a criminalidade estatal, organizações criminosas e organizações terroristas à criminalidade empresarial, com a ressalva de que, para o desenvolvimento do presente Capítulo serão levados em consideração os casos nos quais $\mathrm{o}(\mathrm{s})$ dirigente(s) da organização empresarial emite(m) ordens de conteúdo criminoso a seus subordinados, que a concretiza $(\mathrm{m})$ dolosamente, sendo que o delito praticado pelo subordinado encontra-se vinculado à natureza da atividade desenvolvida pela empresa, bem como aquelas situações nas quais o crime levado a efeito pelo subordinado derivou de uma "política" ou "filosofia" delitiva da empresa que proporciona um ambiente propício para o crime que pode ser perpetrado pelo subordinado ainda que não exista ordem.

\subsubsection{Argumentos contrários à aplicação da teoria dos aparatos às empresas}

As críticas à utilização da teoria da autoria mediata em virtude da utilização de aparatos organizados de poder na criminalidade empresarial são majoritárias na doutrina alemã e espanhola ${ }^{578}$, e ostentam, como traço comum, a afirmação de que o $B H G$ foi caminhou demasiadamente longe ao decidir o caso dos guardas do Muro de Berlim.

Dessarte, os argumentos contrários podem ser sintetizados nos seguintes termos: (i) a empresa somente existe em conformidade com o ordenamento jurídico e para exercer atividade lícita ${ }^{579}$; (ii) não existe, no âmbito empresarial, fungibilidade do executor

\footnotetext{
${ }^{578}$ Para uma ampla referência de autores: FARALDO CABANA, Patricia. Responsabilidad penal del dirigente en estructuras jerárquicas: la autoría mediata con aparatos organizados de poder, cit., p. 307.

${ }^{579}$ MEINI, Iván. Responsabilidad penal del empresario por los hechos cometidos por sus subordinados, cit., p. 1984. O motivo adotado por Elena B. Marín de Espinosa Ceballos para negar o traslado da teoría da autoria mediata mediante aparatos organizados de poder para as sociedades empresárias é substancialmente
} 
material (autor imediato) ${ }^{580}$, pois ele pode se recusar, sem maiores consequências, ao cumprimento da ordem ilegal e, então despedir-se do trabalho; (iii) falta, portanto, o automatismo que caracteriza o aparato de $\operatorname{poder}^{581}$; (iv) a sociedade empresária não apresenta estrutura hierárquica rígida, como acontece nos aparatos organizados de $\operatorname{poder}^{582}$; (v) no contexto empresarial o executor material do delito no mais das vezes não tem o conhecimento pleno do caráter de sua conduta, notadamente nos delitos especiais, que exigem conhecimentos técnicos específicos; (vi) a teoria dos aparatos organizados de poder é desnecessária na criminalidade de empresa, pois na maioria dos casos a direção da empresa domina a vontade dos subordinados em razão do erro e da coação ${ }^{583}$.

Concretamente: a base da tese refratária reside no fato de se alagar em demasia a responsabilidade penal do empresário, que, assim, passa a ser imputado por tudo aquilo que ocorre no âmbito da organização empresarial, ainda que seja de seu conhecimento indireto. Sob esse prisma, Schünemann vislumbra a possibilidade de autoria mediata somente naqueles aparatos organizados que se utilizam da força ${ }^{584}$. Como as empresas juridicamente conformadas não se valem desse expediente, o homem de trás será indutor, embora relacionado a uma autoria por omissão, vislumbrando Schünemann, por conseguinte, uma situação de coautoria estabelecida entre o autor mediato e imediato ${ }^{585}$.

diverso. Para Espinosa Ceballos a teoria de Claus Roxin não é válida para resolver os problemas de responsabilidade criminal no âmbito das empresas, nem mesmo da criminalidade organizadas, não porque não operam à margem do ordenamento jurídico, pois este é um requisito desnecessário para a configuração do aparato de poder, mas porque Espinosa Ceballos descarta a possibilidade de existir autoria mediata quando o executor é plenamente responsável (MARÍN DE ESPINOSA CEBALLOS, Elena B. Criminalidad de empresa: la responsabilidad penal en las estructuras jerárquicamente organizadas, cit., p. 94-95).

${ }^{580}$ FARALDO CABANA, Patricia. Responsabilidad penal del dirigente en estructuras jerárquicas: la autoría mediata con aparatos organizados de poder, cit., p. 309; MEINI, Iván. Responsabilidad penal del empresario por los hechos cometidos por sus subordinados, cit., p. 193 e ss.; MARÍN DE ESPINOSA CEBALlOS, Elena B. Criminalidad de empresa: la responsabilidad penal en las estructuras jerárquicamente organizadas, cit., p. 77; Problemas de autoría y participación en el derecho penal económico, o ¿cómo imputar a título de autores a las personas que sin realizar acciones ejecutivas, deciden la realización de un delito en el ámbito de la delincuencia económica empresarial?, cit., p. 80.

${ }^{581}$ FARALDO CABANA, Patricia. Responsabilidad penal del dirigente en estructuras jerárquicas: la autoría mediata con aparatos organizados de poder, cit., p. 316.

${ }^{582}$ Id. Ibid., p. 311; ILHARRESCONDO, Jorge Marcelo. Delitos societarios, cit., p. 157.

${ }^{583}$ MEINI, Iván. Responsabilidad penal del empresario por los hechos cometidos por sus subordinados, cit., p. 186.

${ }^{584}$ SCHÜNEMANN, Bernd. El tempestuoso desarrollo de la figura de la autoría mediata. In: 1. ed. Santa Fe: Rubinzal-Culzoni, 2009. p. 534. (Colección Autores de Derecho Penal, t. 1). Obras.

${ }^{585}$ Id. Ibid., p. 534. 
Para resolver a questão da criminalidade empresarial e colmatar eventuais lacunas de punibilidade, Claus Roxin propõe que a imputação dos dirigentes empresariais seja analisada a partir do dever de garante para o empresário, de sorte que a conduta criminosa perpetrada no interior da organização empresarial a ele pode ser imputada por omissão $^{586}$. Nessa perspectiva, se o empresário determinar a um subordinado que ele cometa uma infração penal no contexto da organização empresarial ou, ainda, que ele não impeça a realização do fato, existirá autoria pela sua posição de garante, ou, mais precisamente uma autoria em função da posse de deveres e não do domínio da organização ${ }^{587}$.

Essa realidade foi, inclusive, acolhida no artigo 13 do Corpus Iuris instituído para a defesa dos interesses financeiros da Comunidade Europeia ${ }^{588}$ : "o crime que uma pessoa comete por conta da empresa, submetendo-se essa pessoa à autoridade do administrador ou de outro com poder de decisão ou controle, faz com que este indivíduo hierarquicamente superior seja também penalmente responsável, quando possui conhecimento do cometimento do crime, deu instrução para sua realização, ou deixou acontecer ou omitiu as medidas necessárias de controle" ${ }^{\text {589 }}$.

Francisco Muñoz Conde, a seu turno, também refuta o aparecimento de aparatos organizados de poder em ambientes empresariais. Para o professor espanhol, afigura-se difícil reconhecer a existência, na esfera empresarial, da fungibilidade dos executores imediatos, principalmente porque, ao contrário das outras modalidades de aparato, na empresa o executor das ações concretas que representam o delito no mais das vezes não é um anônimo cumpridor de ordens que pode ser substituído arbitrariamente,

\footnotetext{
${ }^{586}$ ROXIN, Claus. Autoria mediata por meio de domínio de organização, cit., p. 340-341. De fato, para Roxin, "É a posição de garante do empresário que o faz autor, conforme a regra dos delitos de infração de dever, independentemente de se a sua contribuição para o fato típico consiste em um fazer ou em um mero deixar acontecer que, em razão de sua não entrada em cena, o leva a responder pela ocorrência do evento que deveria ter sido obstado. Pode-se enxergar uma tal 'autoria mediata em virtude da posse de dever' como uma forma autônoma de autoria mediata” (Id. Ibid., p. 341).

${ }^{587}$ SOUZA, Artur de Brito Gueiros. Teoria do domínio do fato e sua aplicação na criminalidade empresarial: aspectos teóricos e práticos. Revista Brasileira de Ciências Criminais, São Paulo, ano 21, n. 105, p. 79, nov./dez. 2013.

${ }^{588}$ Projeto de Código para crimes transnacionais econômicos no âmbito da Comunidade Europeia.

${ }^{589}$ No mesmo sentido, reconhecendo hipótese de posição de garante do empresário: MARÍN DE ESPINOSA CEBALLOS, Elena B. Criminalidad de empresa: la responsabilidad penal en las estructuras jerárquicamente organizadas, cit., p. 126.
} 
mas uma pessoa que possui conhecimentos especiais sem os quais não seria possível a realização da conduta e que, por tal razão, não pode ser substituído com facilidade ${ }^{590}$.

Muñoz Conde propõe, assim, que se resolva penalmente a questão da imputação do dirigente da organização empresarial por intermédio de uma "coautoria mediata" ${ }^{\text {591 }}$. Para tanto, Muñoz Conde toma de empréstimo a doutrina de Jakobs, argumentando que, nos casos de grandes sociedades empresárias, a intervenção do conselheiro em uma votação do Conselho de Administração não consubstancia uma execução do fato, senão sua preparação, sendo que o resultado da votação é executado em todos os casos relevantes por pessoas responsáveis.

\subsubsection{Argumentos favoráveis à aplicação da teoria dos aparatos organizados de poder às sociedades empresárias}

Os argumentos favoráveis ao reconhecimento da autoria mediata mediante a utilização da teoria dos aparatos organizados de poder às empresas direcionam-se, em sua maioria, à constatação de que o modelo organizacional das sociedades empresárias não difere substancialmente dos paradigmas de aparatos de poder concebidos por Claus Roxin (organizações paraestatais, organizações criminosas e organizações terroristas) ${ }^{592}$.

Sob esse contexto, Iván Meini entende perfeitamente possível a aplicação da teoria da autoria mediata em virtude do domínio sobre a organização para o fim de punir os membros dos órgãos de direção da empresa, embora admita que, por apresentar funcionamento diverso daquele normalmente encontrado no aparato de poder, serão raras as oportunidades nas quais se poderá imputar responsabilidade penal às pessoas que exercem o comando a título de autor mediato e considerar, ao mesmo tempo, o executor do

\footnotetext{
${ }^{590}$ Problemas de autoría y participación en el derecho penal económico, o ¿cómo imputar a título de autores a las personas que sin realizar acciones ejecutivas, deciden la realización de un delito en el ámbito de la delincuencia económica empresarial?, cit., p. 80.

${ }^{591}$ Id. Ibid., p. 81.

${ }^{592}$ MARÍN DE ESPINOSA CEBALLOS, Elena B. Criminalidad de empresa: la responsabilidad penal en las estructuras jerárquicamente organizadas, cit., p. 69.
} 
fato delituoso como autor penalmente responsável ${ }^{593}$.

Isso porque, para Iván Meini, existiriam cinco características presentes nas sociedades empresárias que obstariam, na maior parte dos casos, a utilização automática da teoria dos aparatos organizados de poder mundo empresarial ${ }^{594}$.

A primeira diz respeito à ausência, na sociedade empresarial, do que Meini denomina de "atitude criminal coletiva", ou seja, as empresas não se constituem ex profeso com um fim delitivo, ao contrário do que sucede com as organizações criminosas ${ }^{595}$. A ausência desse elemento faz com que Meini - que neste aspecto segue a FriedrichChristian Schroeder na verificação dos requisitos do aparato de poder - observe que dificilmente o subordinado de uma empresa estará predisposto à prática delitiva determinada pelo dirigente ou órgão de administração da pessoa jurídica ${ }^{596}$.

A segunda característica encontra-se atrelada à utilidade prática da teoria sob análise. Segundo Iván Meini, pode-se objetar que, na maioria dos casos, o que sucede no interior da empresa consubstancia hipótese de domínio de vontade por coação ou erro notadamente de proibição - do autor imediato e não pelo domínio do aparato de poder. Nesse sentido, a coação derivaria da "pressão" e correspondente "insegurança" produzidas nos funcionários com o fim de alcançar as metas econômicas desenhadas pela empresa que, relembre-se, conforma a sua atividade inexoravelmente em virtude da busca incessante do lucro ${ }^{597}$. De outro lado, a cogitação do erro produzido no subordinado aparece relevante porque, em regra, o conteúdo das ordens editadas no seio da empresa não é, em si mesmo, ilícito, bem como porque será pouco habitual que os funcionários persigam, com conhecimento, um objetivo criminoso quando cumprem as determinações ou, de outro lado, atuem com desconhecimento de que com as suas intervenções eles estão contribuindo a um fato global delitivo planejado pelo dirigente do ente empresarial ${ }^{598}$.

\footnotetext{
${ }^{593}$ MEINI, Iván. Responsabilidad penal del empresario por los hechos cometidos por sus subordinados, cit., p. 183-184.

${ }^{594}$ Id. Ibid., p. 184 e ss.

${ }^{595}$ Id. Ibid., p. 184. A ausência dessa atitude criminal coletiva na empresa relaciona-se, para Iván Meini, com o fato de as empresas não operam de modo desvinculado do ordenamento jurídico (Id. Ibid., p. 184).

${ }^{596}$ Id. Ibid., p. 185.

${ }^{597}$ Id. Ibid., p. 186.

${ }^{598}$ Id. Ibid., p. 189. Desse modo, analisada a questão pelo prisma do elemento subjetivo, os comportamentos penalmente relevantes dos subordinados no âmbito da empresa resolver-se-ão, na maioria das vezes, através
} 
A terceira característica impeditiva relaciona-se aos casos nos quais o delito perpetrado no âmbito da empresa é de natureza especial, ou seja, exige do sujeito ativo uma qualidade especial. Neste caso, ressalta Iván Meini que, quando o subordinado constitui-se em um extraneus e não realizar atividade de administração da empresa, isto é, não empolgar a especial condição exigida pelo tipo penal, descaberá considerá-lo como autor imediato, remanescendo, na hipótese, a participação pela cooperação necessária ${ }^{599}$.

A quarta característica, intitulada por Iván Meini de risco permitido, referese àquelas situações em que a imputação dos membros dos órgãos de direção da empresa deriva da contratação ou nomeação de funcionários ou por haver proporcionado os instrumentos para o trabalho ou as informações necessárias. Em regra não haverá espaço para imputação, pois a lógica da contratação de pessoas na atividade empresarial caminha no sentido de que somente os mais competentes devem ser incorporados, bem como porque, e principalmente, a autoria mediata pelo domínio de vontade somente se corporifica em condutas comissivas. Entretanto, afora essa situação, Meini admite imputar responsabilidade penal aos dirigentes da organização empresarial pelos fatos levados a efeito por funcionários manifestamente incapazes de desempenhar adequadamente suas funções e que, por conta disso, criaram um risco não permitido. Concretamente: para Meini, existe, na espécie, uma quebra do dever objetivo de cuidado in elegendo que fundamenta a imputação penal dos componentes dos órgãos de direção ${ }^{600}$.

A quinta e talvez mais conhecida característica obstativa trazida por Iván Meini vincula-se à ideia de que os executores das ordens emanadas sob contexto empresarial, ao contrário dos aparatos de poder, não são substituíveis, mecanicamente cambiáveis ou, para usar o termo empregado por Claus Roxin, não são fungíveis. Esse elemento, como examinado anteriormente, tem sido frequentemente criticado pela doutrina como condicionante do aparecimento fático do aparato, de sorte que, para Iván Meini, ele não tem a aptidão de impedir que se translade a teoria da autoria mediata em razão de aparatos organizados de poder às sociedades empresárias. A uma, pois é possível falar na

\footnotetext{
do dolo eventual, da imprudência - conquanto incomuns no Direito Penal Econômico - ou mesmo de condutas não puníveis em razão do desconhecimento do caráter ilícito pelo agente (MEINI, Iván. Responsabilidad penal del empresario por los hechos cometidos por sus subordinados, cit., p. 189).

${ }^{599}$ Id. Ibid., p. 191.

${ }^{600}$ Id. Ibid., p. 192.
} 
necessidade de especialização de membros tanto em organizações empresariais como em organizações criminosas, isto é, ambas podem apresentar componentes não cambiáveis ${ }^{601}$. A duas, porque nos aparatos organizados criminosos, a admissão de novos membros passa por um processo mais complexo do que aquele conferido ao trabalhador de uma empresa. A três, porque os membros do aparato organizado de natureza genuinamente criminosa vivem permanentemente dissociados do ordenamento jurídico, o que não ocorre com as organizações empresariais. Essa circunstância, para Meini, faz com que o aparato criminoso conte com pouquíssimas pessoas disponíveis à execução de suas ordens ${ }^{602}$.

Patrícia Faraldo Cabana, a seu turno, também admite que as organizações empresariais possam corporificar aparatos de poder e, nessa condição, ensejar que o empresário dirigente da sociedade empresária seja considerado autor mediato de condutas criminosas cometidas pelos subordinados em atendimento às ordens emitidas pelos superiores $^{603}$. Faraldo Cabana, porém, pondera que o fundamento principal para imputar responsabilidade penal por autoria mediata mediante domínio da organização radica na teoria do injusto coletivo que surge no ambiente empresarial, nos termos preconizados por Lampe $^{604}$. Sob esse contexto, Patrícia Faraldo Cabana defende que as empresas delineadas hierarquicamente no plano vertical e com divisão de funções no plano horizontal podem perfeitamente ser equiparadas aos aparatos criminosos estatais e paraestatais, desde que se dediquem à comissão de delitos como resultado de uma atividade exclusiva ou principal ${ }^{605}$.

Fora dessa hipótese, ou seja, identificada uma sociedade empresária que tangencia apenas esporadicamente a atividade criminosa, não há falar-se em domínio da organização no ambiente empresarial, modo que de Faraldo Cabana sustenta a necessidade de recorrer a outras categorias jurídicas para a concretização da imputação penal ${ }^{606}$.

\footnotetext{
${ }^{601}$ MEINI, Iván. Responsabilidad penal del empresario por los hechos cometidos por sus subordinados, cit., p. 194. Pense-se, para seguir o exemplo de Meini, em organizações criminosas mais complexas, que exigem a presença de membros com conhecimentos especiais relacionados à falsificação de documentos, à elaboração de explosivos, ao transporte de substâncias entorpecentes etc. (Id. Ibid., p. 194).

${ }^{602}$ Id. Ibid., p. 194.

${ }^{603}$ FARALDO CABANA, Patricia. Responsabilidad penal del dirigente en estructuras jerárquicas: la autoría mediata con aparatos organizados de poder, cit., p. 324.

${ }^{604}$ Id. Ibid., p. 318 e ss.

${ }^{605}$ Id. Ibid., p. 318 e ss. No mesmo sentido: MARTÍNEZ-BUJÁN PÉREZ, Carlos. Derecho penal económico y de la empresa: parte general, cit., p. 497.

${ }^{606}$ Faraldo Cabana Ibidem, p. 324.
} 


\subsubsection{Tomada de postura: o critério da função social da empresa}

As organizações empresariais mais modernas e sofisticadas apresentam características similares aos aparatos organizados de poder constituídos à margem do ordenamento jurídico-penal. A pluralidade de membros, a existência de uma rígida estrutura hierárquica com divisão de funções e a presença de subordinados substituíveis dada a superabundância de mão de obra são elementos frequentemente encontrados em estruturas empresariais complexas.

Sob esse contexto, não nos parece possível recusar, de modo absoluto, a incidência da teoria da autoria mediata mediante o domínio de vontade por intermédio de aparatos organizados de poder, concebida originariamente por Roxin, em relação aos delitos comissivos praticados pelos dirigentes das sociedades empresárias.

O requisito da dissociação do Direito não se revela suficientemente delineado para impedir o automatismo do aparato de poder. Com efeito, afigura-se contraditório admitir a existência de aparatos organizados de poder no âmbito da criminalidade estatal e não admiti-lo em relação às organizações empresariais que ostentam poder de comando, hierarquia e predisposição do agente no cometimento do fato delituoso. Coloquemos de ouro modo: Hitler ascendeu ao poder tornando-se Chanceler do Reich alemão em 30 de janeiro 1933 sem violar qualquer artigo da Constituição de Weimar. O mesmo sucedeu com a presidência de Alberto Fujimori no Peru. Não obstante, ambos os casos deram ensejo à formação de típicos aparatos organizados de poder reconhecidos por Claus Roxin e pela jurisprudência.

A sociedade empresária consubstancia um ente genuinamente jurídico não apenas porque a sua atividade irradia efeitos jurídicos, mas porque ela somente existe juridicamente, vale dizer, porque o ordenamento brasileiro lhe confere personalidade jurídica. E se é verdade que sociedade empresária somente encontra significado na ordem jurídica, não é menos verdadeiro que a utilização da estrutura da pessoa jurídica para o cometimento de crimes desvirtua seu objeto social e subverte a função social da empresa. 
O postulado da função social encontra positivação no artigo 170 , III, da Constituição da República, como derivação da função social da propriedade, a qual, por sua vez, constitui-se como um dos princípios da ordem econômica ${ }^{607}$. No plano infraconstitucional, referem-se expressamente à necessidade de exercício da atividade de empresa em consonância com a sua função na sociedade brasileira o artigo 116, § único, da Lei n. $^{\circ}$ 6.404/1976 (Lei das Sociedades por Ações) ${ }^{608}$ e o artigo 47 da Lei n. ${ }^{\circ} 11.101 / 2005$ (Lei de Recuperação Judicial, Extrajudicial e Falência) ${ }^{609}$.

A instituição do Estado Social, já recordava Fábio Konder Comparato na década de setenta, impôs duas relevantes consequências jurídicas para as organizações empresariais. "De um lado, o exercício da atividade empresarial já não se funda na propriedade dos meios de produção, mas na qualidade dos objetivos visados pelo agente (justificação teleológica e não pelo título causal); sendo que a ordem jurídica assina aos particulares e, especialmente, aos empresários, a realização obrigatória de objetivos sociais, definidos na Constituição e instrumentados na lei do plano. De outro lado, o lucro, longe de aparecer como o fruto da propriedade do capital, passa a exercer a função de prêmio ou incentivo ao regular desenvolvimento da atividade empresária, obedecidas as finalidades sociais fixadas em lei" ${ }^{610}$.

\footnotetext{
${ }^{607}$ SILVA, José Afonso da. Comentário contextual à Constituição. São Paulo: Malheiros Ed., 2005. p. 713. Com efeito, segundo José Afonso da Silva, diante do tratamento conferido pela Constituição Federal de 1988 à atividade econômica, tem-se que a "iniciativa privada é amplamente condicionada ao sistema da Constituição econômica brasileira. Se ela se implementa na atuação empresarial, e esta se subordina ao princípio da função social, para realizar ao mesmo tempo o desenvolvimento nacional, assegurada a existência digna de todos, conforme os ditames da justiça social, bem se vê que a liberdade de iniciativa só se legitima quando voltada à efetiva consecução desses fundamentos, fins e valores da ordem econômica" (Id. Ibid., p. 713).

${ }^{608}$ Art. 116. Entende-se por acionista controlador a pessoa, natural ou jurídica, ou o grupo de pessoas vinculadas por acordo de voto, ou sob controle comum, que: a) é titular de direitos de sócio que lhe assegurem, de modo permanente, a maioria dos votos nas deliberações da assembleia-geral e o poder de eleger a maioria dos administradores da companhia; e b) usa efetivamente seu poder para dirigir as atividades sociais e orientar o funcionamento dos órgãos da companhia. Parágrafo único. O acionista controlador deve usar o poder com o fim de fazer a companhia realizar o seu objeto e cumprir sua função social, e tem deveres e responsabilidades para com os demais acionistas da empresa, os que nela trabalham e para com a comunidade em que atua, cujos direitos e interesses deve lealmente respeitar e atender.

${ }^{609}$ Art. 47. A recuperação judicial tem por objetivo viabilizar a superação da situação de crise econômicofinanceira do devedor, a fim de permitir a manutenção da fonte produtora, do emprego dos trabalhadores e dos interesses dos credores, promovendo, assim, a preservação da empresa, sua função social e o estímulo à atividade econômica. Também: SZTAJN, Rachel. Comentários à Lei de Recuperação de Empresas e Falência: Lei 11.101/2005, artigo por artigo. Coordenação Francisco Satiro de Souza Junior, Antônio Sérgio A. de Moraes Pitombo. 2. ed. São Paulo: Ed. Revista dos Tribunais, 2007. p. 222 e ss.

${ }^{610}$ COMPARATO, Fábio Konder. O poder de controle na sociedade anônima. 3. ed. Rio de Janeiro: Forense, 1983. p. 296.
} 
Isso não significa, como ressalva Comparato, que a sociedade empresária deva renegar sua finalidade primordial focada na maximização do lucro e transformar-se em uma espécie de "segundo Estado" cujas funções residem na concretização do interesse público, mas que, em havendo conflito entre a busca pelo lucro e o atendimento dos interesses comunitários, deve necessariamente prevalecer o segundo ${ }^{611}$.

“A liberdade individual de iniciativa empresária - pontua Fábio Comparato - não torna absoluto o direito ao lucro, colocando-o acima do cumprimento dos grandes deveres de ordem econômica e social, igualmente expressos na Constituição" ${ }^{\text {"612 }}$.

Sendo assim, ainda que se admita, na linha do preconizado por Claus Roxin e pela doutrina majoritária, o condicionamento do aparato de poder à sua dissociação do ordenamento jurídico, não se nos afigura possível recusar que o desvirtuamento da sociedade empresária possa ensejar essa necessária desvinculação. Mais concretamente: o desvirtuamento do objeto social e a ofensa do princípio constitucional da função social da empresa pela utilização abusiva e criminosa pelos componentes da sociedade podem caracterizar a dissociação do ordenamento jurídico positivo e, dessa forma, ensejar o aparecimento do requisito (desvinculação) para a configuração do aparato de poder.

Aliás, talvez com o mesmo espírito, potencializando os efeitos causados na vida corporativa com a transformação criminosa do objeto social da sociedade empresária, a recente Lei n. ${ }^{\circ}$ 12.846/2013 tornou possível a dissolução compulsória da pessoa jurídica quando comprovado que (i) a personalidade jurídica foi utilizada de forma habitual para facilitar ou promover a prática de atos ilícitos, ou que (ii) ela foi constituída para ocultar ou dissimular interesses ilícitos ou a identidade dos beneficiários dos atos praticados ${ }^{613}$.

Existe, ainda, outra situação: a atividade de empresa está vocacionada à maximização do lucro através de comportamentos lícitos, desde que conformados, obviamente, ao princípio da função social. De outro lado, as organizações criminosas também visam a obtenção de benefícios econômicos, mas por intermédio de expedientes criminosos. Não obstante, como apontamos anteriormente, existem inegáveis pontos de

${ }^{611}$ COMPARATO, Fábio Konder. O poder de controle na sociedade anônima, cit., p. 301.

${ }^{612}$ Id. Ibid., p. 301.

${ }^{613}$ Artigo $19, \S 1^{\circ}$, da Lei n. ${ }^{\circ} 12.846 / 2013$. 
contatos entre as organizações empresariais e as organizações criminosas. Dessarte, a deliberada estruturação da empresa no sentido de sistematicamente cometer crimes equipara-a as organizações criminosas, desde que presentes os requisitos legais.

A consequência: uma vez assentada concretamente essa equiparação e presentes os demais requisitos exigidos para a existência do aparato (poder de mando, hierarquia, fungibilidade de executores e predisposição do executor ao cometimento do delito), abre-se a possibilidade de aplicar-se a teoria do domínio de vontade por intermédio de aparatos organizados de poder, considerando-se o dirigente empresarial um autor mediato. O papel de apreciar a presença dos requisitos, na linha do magistério de Herzberg, caberá ao juiz, que deverá proceder à sua verificação de modo suficientemente motivado.

Por derradeiro: se no curso de sua vida corporativa a sociedade empresária desviar-se de seu objeto social, transmudando-se em aparato organizado para a prática de infrações penais graves, aqui também será possível equipará-la à organização criminosa. Neste caso, dever-se-á verificar em que momento a sociedade empresária adotou uma filosofia empresarial criminógena; somente a partir desde momento poder-se-á cogitar da existência de um aparato organizado de poder e a consideração do domínio da organização.

\subsubsection{A teoria da autoria mediata em razão de aparatos organizados de poder no Brasil: doutrina e análise crítica da jurisprudência}

A teoria da autoria mediata por intermédio de aparatos organizados de poder não tem merecido da doutrina penal brasileira atenção especial. Essa situação derivaria, segundo Luís Greco e Alaor Leite, da "contingência legislativa de o art. 29 do CP, nesse aspecto pouco diferindo do art. 25 do CP, indicar e mesmo inclinar-se a um conceito extensivo e unitário de autor, que não distingue, no plano do injusto, entre autores e partícipes, mas que declara autor todo aquele que, de qualquer forma, concorre para o crime" ${ }^{\text {"614 }}$.

\footnotetext{
${ }^{614}$ GRECO, Luís; LEITE, Alaor. O que é e o que não é a teoria do domínio do fato sobre a distinção entre autor e partícipe no Direito Penal, cit., p. 61.
} 
Os manuais brasileiros de Direito Penal que, de algum modo, dedicaram algumas páginas à construção teórica de Claus Roxin, fizeram-no de modo superficial e, mesmo assim, crítico, conquanto sem qualquer demonstração de suas principais nuances $^{615}$, à exceção das obras de Nilo Batista ${ }^{616}$, Juan Carlos Ferré Olivé, Miguel Ángel Núñez Paz, William Terra de Oliveira e Alexis Couto de Brito ${ }^{617}$, Arthur Pinto de Lemos Junior $^{618}$ e dos recentes artigos elaborados por Luís Greco e Alaor Leite ${ }^{619}$ e por Artur de Brito Gueiros Souza ${ }^{620}$.

De fato, afigura-se relevante a discussão se o ordenamento jurídico penal brasileiro expressamente admite a autoria mediata através da utilização de aparatos organizados de poder, na esteira do tem sucedido com outros países com a mesma tradição romano-germânica, como é o caso da Alemanha ${ }^{621}$, da Espanha ${ }^{622}$ e de Portugal ${ }^{623}$.

Nesse passo, não podemos perder de vista a existência de diversos dispositivos legais que, ao menos aparentemente, possibilitariam a incidência, no Brasil, dessa peculiar expressão da teoria do domínio do fato, inclusive no âmbito das organizações empresariais. Nesse sentido, merecem registro o artigo 11, caput, da Lei $\mathrm{n}^{\circ}$ $8.137 / 1990^{624}$, o artigo 75 da Lei $n .^{\circ} 8.078 / 1990^{625}$ e o recente artigo $2^{\circ}$, $\$ 3^{\circ}$, da Lei.$^{o}$

${ }^{615}$ ZAFFARONI, Eugenio Raúl; PIERANGELI, José Henrique. Manual de direito penal brasileiro: parte geral, cit., p. 680-681; GRECO, Rogério. Curso de direito penal: parte geral. 6. ed. Rio de Janeiro: Impetus, 2006. v. 1, p. 481.

${ }^{616}$ BATISTA, Nilo. Concurso de agents: uma investigação sobre os problemas da autoria e da participação no direito penal brasileiro, cit., p. 129 e ss.

${ }^{617}$ FERRÉ OLIVÉ, Juan Carlos; ÁNGEL NÚÑEZ PAZ, Miguel; OLIVEIRA, William Terra de; BRITO, Alexis Couto de. Direito penal brasileiro: parte geral, princípios fundamentais e sistema, cit., p. 547 e ss.

${ }^{618}$ LEMOS JUNIOR, Arthur Pinto de. Crime organizado: uma visão dogmática do concurso de pessoas. Porto Alegre: Verbo Jurídico, 2012. p. 141 e ss.

${ }^{619}$ GRECO, Luís; LEITE, Alaor. O que é e o que não é a teoria do domínio do fato sobre a distinção entre autor e partícipe no Direito Penal, cit., p. 61-80.

${ }^{620}$ SOUZA, Artur de Brito Gueiros. Teoria do domínio do fato e sua aplicação na criminalidade empresarial: aspectos teóricos e práticos, cit., p. 59-93.

${ }^{621} \S 25$. Autoría (1) Se castiga como autor a quien cometa el hecho punible por si mismo o a través de otro.

(2) Si varios cometen mancomunadamente el hecho punible, entonces se castigará a cada uno como autor (coautoría).

${ }^{622}$ Art. 28: "Son autores quienes realizan el hecho por sí solos, conjuntamente o por medio de otro del que se sirven como instrumento. También serán considerados autores: a) Los que inducen directamente a otro u otros a ejecutarlo. b) Los que cooperan a su ejecución con un acto sin el cual no se habría efectuado".

${ }^{623}$ Art. 26: Autoria. "É punível como autor quem executar o facto, por si mesmo ou por intermédio de outrem, ou tomar parte directa na sua execução, por acordo ou juntamente com outro ou outros, e ainda quem, dolosamente, determinar outra pessoa à prática do facto, desde que haja execução ou começo de execução".

${ }^{624}$ Art. 11: Quem, de qualquer modo, inclusive por meio de pessoa jurídica, concorre para os crimes definidos nesta Lei, incide nas penas a estes cominadas, na medida de sua culpabilidade.

${ }^{625}$ Art. 75: Quem, de qualquer forma, concorrer para os crimes referidos neste Código incide nas penas a esses cominadas na medida de sua culpabilidade, bem como o diretor, administrador ou gerente da pessoa 
12.850/2013 $3^{626}$, aplicável especificamente à realidade das organizações criminosas.

A jurisprudência, a seu turno, tem se mostrado reticente na consideração da teoria da autoria mediata mediante aparatos organizados de poder, a despeito dos seus mais de cinquenta anos de vida. Curiosamente, os poucos precedentes judiciais encontrados, todos oriundos da Justiça Federal, dizem respeito à criminalidade empresarial ${ }^{627}$, setor que, como vimos, configura o ambiente mais inóspito para a incidência da teoria de Claus Roxin, e nenhum deles enfrenta a necessidade, ou não, de lançar mão do recurso teórico diante da redação do artigo 29 do Código Penal brasileiro.

A leitura das decisões judiciais, contudo, revela que os Tribunais brasileiros talvez não tenham compreendido adequadamente a função e o alcance da teoria do domínio de vontade por aparatos organizados de poder. Muita vez, tem-se a clara impressão que a construção teórica de Roxin foi manejada com o exclusivo escopo de conferir à manifestação judicial - invariavelmente com conteúdo condenatório - uma roupagem dogmática mais elegante e sofisticada, esquecendo-se que essa expressão da teoria do domínio do fato não tem a pretensão de "facilitar" a prova da tese acusatória ou determinar se o agente será ou não punido, mas se o será como autor ou partícipe ${ }^{628} 629$.

jurídica que promover, permitir ou por qualquer modo aprovar o fornecimento, oferta, exposição à venda ou manutenção em depósito de produtos ou a oferta e prestação de serviços nas condições por ele proibidas.

${ }^{626}$ A pena é agravada para quem exerce o comando, individual ou coletivo, da organização criminosa, ainda que não pratique pessoalmente atos de execução.

${ }^{627}$ Esse panorama pode ser modificado em breve em razão das recentes denúncias promovidas pelo Ministério Público Federal pelo cometimento de condutas criminosas perpetradas durante a Ditadura Militar, em especial pelo crime (permanente) de sequestro. Na $9^{a}$ Vara Criminal Federal de São Paulo, por exemplo, tramita a ação penal n. ${ }^{\circ}$ 0011580-69.2012.403.6181, na qual Carlos Alberto Brilhante Ustra (conhecido como "Dr. Tibiriçá"), Alcides Singillo e Carlos Alberto Augusto (conhecido como "Carlinhos Metralha”) são acusados de, desde o dia 13 de junho de 1971 até a presente data, privarem ilegalmente a vítima Edgar de Aquino Duarte (que também usava o nome Ivan Marques Lemos) de sua liberdade, mediante sequestro "cometido no contexto de ataque estatal sistemático e generalizado contra a população, tendo eles pleno conhecimento das circunstâncias deste ataque". Neste caso, a denúncia foi integralmente recebida pelo Juiz Federal Hélio Egydio de Matos Nogueira, que, para tanto, se valeu da teoria do domínio do fato para considerar Carlos Alberto Brilhante Ustra autor do delito, consoante se percebe do seguinte período da decisão: "No caso dos autos, o acusado foi autor e possuía o domínio do fato criminoso consistente na privação ilegal da liberdade de EDGAR DE AQUINO DUARTE, primeiro no DOI-CODI/II - Exército, e, posteriormente, nas descendências (sic) do DEOPS/SP de onde a vítima desapareceu. O acusado, comandante do DOI-CODI na época dos fatos, participava, coordenava e determinava todas as ações repressivas ali praticadas, sendo inegável que detinha o domínio dos fatos criminosos".

${ }^{628}$ GRECO, Luís; LEITE, Alaor. O que é e o que não é a teoria do domínio do fato sobre a distinção entre autor e partícipe no Direito Penal, cit., p. 62.

${ }^{629}$ Outro defeito notado nas decisões judiciais proferidas pelos Tribunais brasileiros encontra-se relacionado à patente carência de motivação acerca da existência dos requisitos e pressupostos objetivos e subjetivos para 
A advertência de Luís Greco e de Alaor Leite, sob esse panorama, exsurge profundamente esclarecedora: "Talvez o erro mais comum e menos observado é fundamentar o status de alguém como autor atribuindo-lhe o domínio do fato. Do ponto de vista da teoria e da metodologia do direito, a ideia de conceitos classificatórios, ou seja, que postulam um conjunto de elementos sob os quais se podem subsumir as diversas formas de comportamento ocorridas na realidade, mas sim conceitos que Roxin caracteriza como abertos e Schünemann como tipológicos" ${ }^{630}$. Desse modo, a "ideia de domínio do fato não é uma definição de autor, mas um critério reitor que deve ser concretizado não pelo juiz no caso concreto, e sim pela doutrina diante de grupos de casos"631.

Caso 1. Crime ambiental (art. 55 da Lei $n^{\circ} 9.605 / 98$ e art. $2^{\circ}$ da Lei $n^{o}$ $8.176 / 91)^{632}$ : a sentença condenatória foi proferida nos seguintes termos Antônio, Jailson e Vanderlei foram denunciados pelo Ministério Público Federal porque, no dia 12/08/2004, Jailson e Antônio foram flagrados extraindo areia e pedregulho sem Licença de Operação emitida pelo órgão ambiental no local denominado Fazenda Santa Adélia, em Américo Brasiliense -SP. Durante a instrução processual ficou provado que na data em que os acusados Jailson e Antonio foram encontrados no local a empresa não tinha autorização, licença ou permissão para operação nem da CETESB nem do DNPM, mas mera licença para instalação concedida em 30/06/2004 e não lhes autorizava a iniciar as operações de extração e lavra. Enquanto Jailson foi flagrado realizando extração dos recursos minerais para a empresa Maria Isabel Orlando Brizolari ME e classificado como "autor direto" do delito pela polícia ambiental, Vanderlei, como representante legal da empresa citada, foi classificado como "autor indireto". No dia do flagrante, Vanderlei confirmou que é representante da empresa e que não tinha licença. Disse que estava aguardando a licença, mas extrai em média $50 \mathrm{~m}^{3}$ de areia. Jailson, por sua vez, disse que era contratado da empresa como draguista e que a draga retira $200 \mathrm{~m}^{3}$ de areia por dia. Antonio disse que só fazia um "bico" abastecendo a draga que funcionava há seis meses. Com efeito, Vanderlei se apresentou à autoridade ambiental no dia dos fatos como o representante da empresa

\footnotetext{
a existência do aparato organizado de poder. Trata-se, sem dúvida, de elemento de índole processual afeto à teoria geral da prova, mas essa circunstância tampouco afasta a obrigação de apontarmos a deficiência.

${ }^{630}$ GRECO, Luís; LEITE, Alaor. O que é e o que não é a teoria do domínio do fato sobre a distinção entre autor e partícipe no Direito Penal, cit., p. 68.

${ }^{631}$ Id. Ibid., p. 68.

${ }^{632}$ Sentença proferida nos autos da ação penal n. ${ }^{\circ}$ 2005.61.20.004991-3 pela $2^{\text {a }}$ Vara de Araraquara.
} 
Maria Isabel Orlando Brisolari ME, e como tal é ele quem responde pelos atos praticados pela mesma. Recebeu procuração de Maria Isabel (autenticada em 23/08/2004) para representar a empresa perante a CETESB, DEPRN, IBAMA e DNPM. Não se trata de responsabilidade objetiva, mas efetivamente, de responsabilidade daquele que toma as decisões, dá ordens e manda executar qualquer atividade que seja feita pela pessoa jurídica (vale lembrar, mera ficção jurídica, que não pensa nem decide nada já que quem pensa e decide é sempre um ser humano). Então, seja teste, seja extração de minerais, é certo que o responsável por essa atividade é Vanderlei. Aliás, Jailson disse que recebeu ordens dele para instalar o cano. Então, apesar de Jailson, na data dos fatos narrados na denúncia estar registrado como empregado de José Roberto Brizolari e Outros, realmente foi encontrado realizando a extração de areia, repito, por ordem de José Roberto.

Análise crítica do Caso 1: em primeiro lugar, não nos pareceu válida, ou mesmo técnica, a utilização, pela magistrada federal, dos termos "autor direto" e "autor indireto" para se referir aos executores como autores imediatos e àquele que determina a ordem como autor mediato. No caso concreto, Antônio e Jailson são, inegavelmente autores, pois detinham o domínio do fato criminoso relacionado à extração ilegal de areia e pedregulho. O equívoco foi considerar Vanderlei como autor indireto (rectius: autor mediato), pois a leitura do decisum não indica, sequer superficialmente, que Vanderlei ostentava o domínio da vontade de Antônio e Jailson mediante coação, erro ou, o que é ainda mais grave, mediante o comando de um aparato organizado de poder. Vale dizer: se a sentença pretendeu dizer que Vanderlei dirigia um aparato de poder e que, em consequência, Antônio e Jailson dele faziam parte na condição de instrumentos, ao se referir ao fato de que Vanderlei "era representante da empresa Maria Isabel Orlando Brisolari $M E$, e como tal é ele quem responde pelos atos praticados pela mesma”, ela deveria indicar concretamente os requisitos necessários à configuração do aparato (poder de mando, hierarquia, fungibilidade de executores e predisposição do executor ao cometimento do delito), os quais, ao que tudo indica, não se estavam presentes na hipótese sob julgamento. Partindo do pressuposto que Vanderlei determinou a extração ilegal de areia e pedregulho, a solução juridicamente correta seria condenar Antônio e Jailson como autores imediatos em razão do domínio da ação de sua próprias condutas e Vanderlei como indutor, sem qualquer necessidade de recorrer ao domínio da organização. 
Caso ${ }^{633}$. Trata-se de acórdão prolatado na apelação criminal n. ${ }^{\circ}$ 2000.72.04.001208-1/SC pelo Tribunal Regional Federal da $4^{\text {a }}$ Região, em que o Ministério Público Federal ofereceu denúncia contra Domival, Lacide e Nilton, dando-os como incursos nas sanções do art. 95, $d$, da Lei 8.212/91, combinado com os arts. 29 e 71 do Código Penal, pela prática dos seguintes fatos delituosos: os denunciados, na condição de administradores da empresa Mineradora São Domingos Ltda., deixaram de recolher aos cofres do INSS as contribuições previdenciárias descontadas dos salários dos empregados da referida empresa. Em determinado momento, o acórdão assinala, em relação à Domival, que ele constituiu, a partir de 23/09/86, o quadro societário da Mineradora São Domingos Ltda., a qual prestava serviços para a Recel S/A-Indústria Cerâmica, sociedade constituída pelos mesmos sócios que a São Domingos. Sua participação na sociedade compreendia 45\% das cotas sociais, assim como a do seu irmão Lacide, embora tenha afirmado que não participava da gestão da empresa. Outrossim, mesmo que não exercesse o poder de gestão que lhe foi conferido pelo Contrato Social, opção sua, referiu o réu, por ocasião do interrogatório, que tinha conhecimento sobre o inadimplemento da obrigação tributária. Portanto, é de ser reconhecida a autoria do delito imputado a Domival. No que tange ao acusado Lacide, assentou o acórdão: Melhor sorte não assiste a Lacide. Tal acusado, que detinha a titularidade de $45 \%$ do capital da São Domingos, igualmente, afirmou não ter envolvimento nos atos administrativos da referida pessoa jurídica e, ainda, imputou a responsabilidade aos demais sócios. A despeito disso, o que se infere dos depoimentos das testemunhas é a ingerência do apelante nos atos de gestão da empresa. MPF: Então o depoente não confirma a afirmação feita perante a Polícia Federal de que a decisão dos

\footnotetext{
${ }^{633}$ No mesmo sentido, ambas do Tribunal Regional Federal da $4^{\text {a }}$ Região: Apelação criminal n. ${ }^{\text { }}$ 2000.72.04.001208-1/SC e Apelação criminal n. ${ }^{\circ}$ 2005.61.71.00.003278/RS, esta com a seguinte Ementa de acórdão: "PENAL. CRIME CONTRA A ORDEM TRIBUTÁRIA. REDUÇÃO OU SUPRESSÃO DE IMPOSTOS FEDERAIS (IRPJ, PIS COFINS, CSLL). AUTORIA. TEORIA DO DOMÍNIO DA ORGANIZAÇÃO. RESPONSABILIDADE PENAL. 1. Comete crime contra a ordem tributária o agente que, dolosamente, suprime o pagamento de tributos, omitindo do Fisco a percepção de rendimentos sujeitos à tributação. 2. Diante da insuficiência das categorias tradicionais de co-autor e partícipe para a atribuição da responsabilidade penal individual, em vista do modelo organizacional que passou, na época moderna, a caracterizar a prática delitiva societária, construiu-se, doutrinariamente, o conceito de autor mediato, assim compreendido como sendo o agente que não tem, propriamente, o domínio do fato, mas sim o da organização , o que sobressai mormente quando o superior hierárquico "sabe más sobre la peligrosidad para los bienes juridicos que su proprio subordinado" (DIEZ, Carlos Gómez-Jara. ¿Responsabilidade penal de los directivos de empresa en virtud de su dominio de la organización? Algunas consideraciones críticas. In Revista Ibero-Americana de Ciências Penais. Porto Alegre: ESMP, 2005. n. 11, p. 13). 3. A responsabilidade penal, em crimes fiscais, é personalíssima, não havendo falar em "culpa concorrente" do profissional de contabilidade que, no mais, não restou demonstrada".
} 
negócios sobre o recolhimento dos tributos sociais cabia aos três administradores, consta à fl. 184 do processo? Testemunha: Não. Eu não posso afirmar categoricamente porque eu não tomava nenhuma decisão, não participava das reuniões. Os sócios realmente eram eles. Agora quem deles tomava as decisões, ou se eram tomadas em conjunto, eu não posso afirmar porque eu não participava das reuniões. Juíza: Em relação à Recel quem tomava as decisões? Testemunha: Era a mesma situação. Eram os três, se reuniam em uma sala. Qual dos três tomava eu não sei. (...) Juíza: E não havia um poder de mando maior uma hierarquia entre os três? Testemunha: Não. Assim não, não havia. Era tudo muito combinado. Juíza: Quem assinava os cheques? Testemunha: Eu acho que os três, acho. Da mesma forma que o irmão Domival, Lacide atestou conhecer as supostas dificuldades financeiras do empreendimento, que teriam resultado na perpetração do ilícito. De outra banda, não se sustenta a alegação de que sua atuação empresarial era restrita à área industrial, pois o que se verifica, dos testemunhos colhidos, é que, embora existente certa divisão de tarefas entre os sócios, todos tinham conhecimento dos fatos e poder de gestão, circunstância que tornava Lacide apto a evitar a prática delitiva. Aduz, ainda, que não recebia valores da sociedade, porém, não comprova tal alegação de forma alguma, em que pese a simples apresentação da contabilidade da empresa ou de declaração de imposto de renda possibilitassem a aferição da existência, ou não, de vínculo econômico com a pessoa jurídica. Logo, também em relação a este corréu está comprovada a autoria delitiva. A imputação de Nilton foi resolvida pelo decisum nos seguintes termos: Nilton passou a integrar a sociedade em razão da doação de 5\% das cotas sociais de cada um dos outros dois sócios em seu favor, contabilizando 10\% do capital social, a partir de 01/01/1993. Tal doação, segundo afirma o réu, foi uma forma de pagamento por serviços prestados pelo apelante, tendo em vista que a empresa, na época, encontrava-se em dificuldades. Não obstante, o fato de o réu ser sócio minoritário não constitui óbice para que este exerça a administração da pessoa jurídica, como de fato ocorria. Nesse sentido é a prova testemunhal colhida na instrução criminal. Outrossim, o apelante afirmou, no interrogatório das fls. 14 a 16, que tinha conhecimento acerca dos fatos delituosos, os quais eram praticados reiteradamente, aplicando-se-lhe, no ponto, o mesmo raciocínio elaborado em relação à atuação de Domival e Lacide, o qual se deixa de repetir por apreço à brevidade. Além disso, a testemunha Paulo Frederico, engenheiro químico da Recel, afirma 
categoricamente que os administradores de ambas as pessoas jurídicas (Recel e São Domingos) são os mesmos. A criminalidade contemporânea, sobretudo nos delitos ditos empresariais, é caracterizada, quase sempre, por um verdadeiro e intrincado sistema de divisão do trabalho delituoso no qual são repartidas, entre os agentes executores da ação criminosa, uma multiplicidade de tarefas, cada qual fundamental à consecução do fim comum. As categorias tradicionais de coautor e partícipe, assim, em vista do modelo organizacional que passou, na época moderna, a caracterizar a prática delitiva societária, não se mostram mais suficientes para a atribuição da responsabilidade penal individual. Foi assim que, a partir de uma formulação idealizada por Claus Roxin em sua monografia Täterschaft und Tatherrschaft ("Autoria e Domínio do Fato") para estabelecer a responsabilidade oriunda dos crimes cometidos pelo Estado nacional-socialista alemão, construiu-se o conceito de autor mediato, ou seja, aquele que, atuando na cúpula da associação criminosa, dirige a intenção do agente responsável pela prática direta do ato delituoso. $\mathrm{O}$ autor mediato não tem, propriamente, o domínio do fato, mas sim o domínio da organização, que, segundo o vaticínio de Jorge de Figueiredo Dias, "constituye una forma de dominio-de-la-voluntad que, indiferente a la actitud subjetivo-psicológica del específico ejecutor, no se confunde con el dominio-del error o con el dominio-de-lacoacción, integrando un fundamento autónomo de la autoría mediata" (Autoría y Participación en el Dominio de la Criminalidad Organizada: el "Dominio de la Organización". In OLIVÉ, Juan Carlos Ferré e BORRALLO, Enrique Anarte. Delincuencia organizada - Aspectos penales, procesales y criminológicos. Huelva: Universidad de Huelva, 1999). "En la discusión que ha sucedido a la construcción científica de la autoría mediata", pondera Carlos Gómez-Jara Diez, "(...) puede observarse cómo la piedra angular radica en el criterio que fundamenta el dominio de la organización", consignando o referido doutrinador, a respeito, que "la responsabilidad del superior jerárquico viene dada por su «dominio de la configuración relevante superior»". Salienta, sobretudo, que "esta possibilidad entra en consideración cuando el superior jerárquico sabe más sobre ma peligrosidad para los bienes juridicos que su proprio subordinado" (¿Responsabilidade penal de los directivos de empresa en virtud de su dominio de la organización? Algunas consideraciones críticas. In Revista Ibero-Americana de Ciências Penais. Porto Alegre: ESMP, 2005. n. 11, p. 13). No caso em tela, Domival, Lacide e Nilton, na qualidade de 
administradores do empreendimento, estavam cientes da ocorrência do delito e tinham condições para impedir sua concretização. São, nos termos da teoria do domínio da organização retrocitada, autores do crime de apropriação indébita previdenciária.

Análise crítica do Caso 2: o acórdão emanado do Tribunal Regional Federal da $4^{\text {a }}$ Região confundiu duas categoriais jurídicas distintas: a responsabilidade do administrador por omissão e a autoria mediata por domínio da vontade em aparatos organizados de poder. Com efeito, durante toda a fundamentação do édito condenatório faz-se menção ao fato de que os Apelantes eram efetivamente administradores da pessoa jurídica Mineradora São Domingos Ltda., em cujo contexto os crimes de apropriação de contribuição previdenciária foram perpetrados, bem como que todos tinham conhecimento dos fatos e poder de gestão, circunstância que os tornava aptos a evitar a prática delitiva, denotando, com isso, que ele estava a tratar de uma conduta omissiva e não comissiva. Nesse sentido, se a administração era conjunta e a resolução criminosa comum, como emanou da motivação do acórdão, tratar-se-ia de coautoria e não de autoria mediata. Sob esse panorama, a citação, no corpo da decisão, da teoria da autoria mediata mediante aparatos organizados de poder de Claus Roxin soou ociosa, quiçá descabida, notadamente quando de tem presente que a teoria do domínio do fato não se aplica aos delitos de dever e, no caso, o Tribunal Regional Federal encontrava-se diante de um (crime omissivo).

Caso 3. Também proveniente do Tribunal Regional Federal da $4^{\mathrm{a}}$ Região, trata-se da apelação criminal n. ${ }^{\circ}$ 2004.04.01.025528-6/RS, que portou a seguinte Ementa: "PENAL E PROCESSO PENAL. CONTAGEM DA PRESCRIÇÃO PUNITIVA. IRRELEVÂNCIA DO TEMPO DE PRISÃO PREVENTIVA. IMPOSSIBILIDADE DE A PARTE INVOCAR NULIDADE A QUE DEU CAUSA. DATA CONTROL. CRIMES CONTRA A ORDEM TRIBUTÁRIA. RESPONSABILIDADE DO ADMINISTRADOR. AUTORIA MEDIATA DO CONTADOR. DOMÍNIO DA ORGANIZAÇÃO. CRIME CARACTERIZADO. EVASÃO DE DIVISAS. PROVA INDIRETA. ADMISSIBILIDADE. CONDUTA SOCIAL NEGATIVA. PROLAÇÃO DE NOVA SENTENÇA. OBSERVÂNCIA DA PENA FINAL APLICADA NA DECISÃO ANULADA. AUSÊNCIA DE REFORMATIO IN PEJUS. CAUSA DE AUMENTO DO ART. 12, I, DA LEI No 8.137/90. AUSÊNCIA DE REFERENNCIA EXPRESSA NA DENÚNCIA. INCIDÊNCIA. PENA DE MULTA. SIMETRIA 
COM A PENA RECLUSIVA FINAL. 1. Para o cálculo da prescrição do jus puniendi pela pena concretizada, é irrelevante o período de prisão provisória, operando-se a contagem sobre o montante total da reprimenda privativa de liberdade infligida, e não sobre o saldo a ser executado.2. No processo penal, não é lícito à parte que deu causa à nulidade argüíla em benefício próprio. Inteligência do art. 565 do CPP. 3. Incorre nas penas do art. $1^{o}$ da Lei $n^{o} 8.137 / 90$ aquele que, livre e conscientemente, mediante omissão de rendimentos e falsificação documental, elide o pagamento de tributos. A simples alegação de ausência de elemento subjetivo no agir do denunciado, sem outras provas que a corrobore, não tem o condão de descaracterizar a intenção do agente, sobretudo quando o número excessivo de notas fiscais adulteradas denota, de forma cristalina, a presença de dolo específico na conduta. 4. Quem administra o estabelecimento é aquele que o conhece e tem responsabilidade por seus pagamentos e noção de tudo a ele pertinente. Mesmo que o responsável pelo empreendimento não seja o executor direto das fraudes fiscais, presumese ser ele quem a autorizou. Nenhum ato acontece em uma empresa sem a ciência de seu administrador. 5. Diante da insuficiência das categorias tradicionais de co-autor e partícipe para a atribuição da responsabilidade penal individual, em vista do modelo organizacional que passou, na época moderna, a caracterizar a prática delitiva societária, construiu-se, doutrinariamente, o conceito de autor mediato, assim compreendido como sendo o agente que não tem, propriamente, o domínio do fato, mas sim o da organização, o que sobressai quando o superior hierárquico "sabe más sobre la peligrosidad para los bienes juridicos que su proprio subordinado" (DIEZ, Carlos Gómez-Jara. ¿Responsabilidade penal de los directivos de empresa en virtud de su dominio de la organización? Algunas consideraciones críticas. In Revista Ibero-Americana de Ciências Penais. Porto Alegre: ESMP, 2005. n. 11, p. 13). 6. Não é crível que, possuindo qualificação técnica exigida para laborar em empresa de vulto, um profissional acostumado às lides contábeis desconhecesse as sérias irregularidades tributárias que estavam sendo cometidas senão diretamente por ele, ao menos sob sua supervisão (por quaisquer que fossem os executores diretos das fraudes constatadas), detendo, pois, o domínio da organização. 7. Ainda que inexistente prova direta do cometimento do crime de evasão de divisas, é de rigor a condenação do réu quando sua responsabilidade penal ressai induvidosa da confissão operada em Juízo e da ausência de apresentação de 
justificativa plausivel para a origem do numerário utilizado para a aquisição de diversos bens em território estrangeiro. 8. Deve o julgador, na dosimetria da pena, ao sopesar a circunstância judicial da conduta social, analisar o comportamento do acusado no trabalho e na vida familiar, ou seja, seu relacionamento com outras pessoas no meio em que vive. 9. Para a ocorrência de reformatio in pejus, é necessário que o magistrado, ao proferir nova sentença, ultrapasse o quantum final das penas concretizadas no decreto condenatório anulado, e não apenas o quantitativo de uma das fases de aplicação das reprimendas. 10. Basta, para a incidência da majorante prevista no art. 12, I, da Lei $n^{o}$ 8.137/90, que a denúncia aponte o montante dos impostos sonegados, não sendo necessária a referência expressa ao fato de que o comportamento do denunciado importou em grave dano à coletividade. 11. Conforme pacífica orientação pretoriana, a fixação da continuidade delitiva deve observar ao número das ocorrências criminosas. 12. A pena de multa, de acordo com a orientação perfilhada pela $4^{a}$ Seção da Corte, deve guardar simetria com a quantificação da sanção privativa de liberdade final, e não com a penabase (EIACR $n^{o}$ 2002.71.13.003146-0/RS, Rel. Des. Federal Luiz Fernando Wowk Penteado, DJE 05.06.2007). 13. O perdimento de bens, nos moldes do art. 91, II, b, do CP, há de ser decretado quando restar demonstrado que a incorporação patrimonial foi realizada com proveitos da prática delitiva. 14. A pretensão de liberdade condicional consiste em matéria afeta ao Juízo da Execução (art. 66, III, e, da Lei $n^{o}$ 7.210/84), devendo a benesse, no momento oportuno, junto ao mesmo ser postulada. Da mesma forma, incumbe ao magistrado responsável pela execução da pena examinar o cabimento de eventual contagem do prazo do livramento condicional para efeito de prescrição da pretensão executória. 15. Redução, à unanimidade, das reprimendas do crime de sonegação fiscal. Pena do crime capitulado no art. 22, §único, da Lei $n^{o}$ 7.492/86, por maioria, reduzida de forma a ensejar a extinção da punibilidade do réu pela prescrição retroativa. Vencida a Relatora".

Análise crítica do Caso 3: o acórdão examinado possui inúmeras impropriedades. Com efeito, afirmar que "Quem administra o estabelecimento é aquele que o conhece e tem responsabilidade por seus pagamentos e noção de tudo a ele pertinente. Mesmo que o responsável pelo empreendimento não seja o executor direto das fraudes fiscais, presume-se ser ele quem a autorizou. Nenhum ato acontece em uma 
empresa sem a ciência de seu administrador" não significa nada, sequer em termos naturalísticos ou, concretamente, em matéria de causalidade. Deveras, administrar, comandar ou dirigir uma pessoa jurídica não é o mesmo que concorrer para a causação do resultado. Além de perigosamente tangenciar a responsabilidade penal objetiva, o acórdão sob exame se utiliza indevidamente de Roxin para fundamentar situação diversa daquela que motivou o professor alemão a elaborar a teoria da autoria mediata por aparatos organizados de poder. E isso porque, pelo que emerge da decisão, sequer existia um aparato hierarquicamente constituído com divisão de tarefas e executores fungíveis ou mesmo que foi emitida uma ordem pelo apelante para que seus subordinados cumprissemna, agindo como se fossem "engrenagens". Em verdade, ao dizer que "Não é crível que, possuindo qualificação técnica exigida para laborar em empresa de vulto, um profissional acostumado às lides contábeis desconhecesse as sérias irregularidades tributárias que estavam sendo cometidas senão diretamente por ele, ao menos sob sua supervisão (por quaisquer que fossem os executores diretos das fraudes constatadas), detendo, pois, o domínio da organização" o acórdão trata, em verdade, de um caso de omissão, de uma quebra do dever de garante, a qual, conforme assentado anteriormente, não se resolve segundo as balizas fixadas pela teoria do domínio do fato ${ }^{634}$.

Caso 4. Trata-se de outro julgamento proveniente do Tribunal Regional Federal da $4^{\mathrm{a}}$ Região (apelação criminal n. ${ }^{\circ}$ 2001.70.09.001504-1/PR). No caso, o Ministério Público Federal ofereceu denúncia contra Marco Antônio, Daniel e Giovana, imputando-lhes a prática do delito previsto no art. 19, § único, da Lei $n^{\circ} 7.492 / 86$, uma vez que, segundo o órgão acusatório, "em 05 de julho de 1999, Marco Antonio, procurador da empresa Ponto Azul Distribuidora de Móveis Ltda., contando com o auxílio de Giovana, funcionária da referida empresa e Daniel, funcionário da empresa Planorga Centro Contábil S/C Ltda., obteve, mediante fraude uma liberação de crédito, em nome da Ponto Azul Distribuidora de Móveis junto ao Banco Nacional de Desenvolvimento Econômico e Social - BNDES, instituição financeira oficial, relativa à $4^{\text {a }}$ (quarta) parcela de um Contrato

\footnotetext{
${ }^{634}$ A propósito, recordam Luís Greco e Alaor Leite que "a mera posição de chefe não significa, por si só, que o agente teria conseguido evitar o resultado no caso concreto, se tivesse agido. E, ainda mais importante, nem tudo que uma pessoa pode evitar tem de ser por ela evitado. Por isso, fala o artigo também em um 'dever de agir', que é concretizado na frase seguinte do citado dispositivo" (GRECO, Luís; LEITE, Alaor. O que é e o que não é a teoria do domínio do fato sobre a distinção entre autor e partícipe no Direito Penal, cit., p. 69).
} 
de Financiamento representado por uma Cédula de Crédito Comercial identificada como FRO 1980/0326/01-7, no valor de $\mathrm{R} \$ 34.000,00$ (Trinta e quatro mil reais), firmada com o agente financeiro Banco Regional de Desenvolvimento do Extremo Sul - BRDE. O valor total do financiamento firmado era de $\mathrm{R} \$ 238.000,00$ (Duzentos e trinta e oito mil reais), dos quais a empresa já havia recebido 3 (três) parcelas, no valor de R \$ 75.000,00 (Setenta e cinco mil reais), $\mathrm{R} \$ 79.000,00$ (Setenta e nove mil reais), $\mathrm{R} \$$ 50.000,00 (Cinqüenta mil reais), respectivamente. De acordo com contrato firmado entre a referida empresa e o Banco Regional de Desenvolvimento do Extremo Sul - BRDE, a liberação de cada parcela de recursos condicionava-se à comprovação de que a beneficiária encontrava-se quite com os tributos e contribuições federais administrados pela Secretaria da Receita Federal, o que poderia ser feito mediante declaração firmada pela empresa ou de Certidão Negativa de Débito. Visando a obtenção fraudulenta da liberação de crédito decorrente do financiamento o denunciado Daniel juntamente com a denunciada Giovana, em conluio e em atendimento ao pedido do procurador da empresa beneficiada, o denunciado Marco Antonio, tendo em vista que, à época a empresa possuía débitos que a impedia de obter certidão negativa junto à Receita Federal, falsificaram uma Certidão de Quitação de Tributos e Contribuições Federais Administrados pela Secretaria da Receita Federal, a qual foi encaminhada pela denunciada Giovana via fax ao Banco Regional de Desenvolvimento do Extremo Sul - BRDE em data de 17 de junho de 1999. A falsificação perpetrada pelos denunciados Daniel e Giovana consistiu na adulteração do número, data de validade e data de emissão em uma cópia da certidão autêntica juntada à fl. 17. A Certidão original possuía o número 2.049.285, sendo alterada para 2.549.239 e as datas de validade e emissão, de 13/04/1999 e 13/10/1998, respectivamente, foram alteradas para, 14/12/1999 e 14/06/1999. Tal falsificação foi constatada, somente após o encaminhamento à Receita Federal pelo Banco Nacional de Desenvolvimento Econômico e Social - BNDES, de listagem contendo o nome e o número do CNPJ de mutuários que obtiveram financiamentos ou liberações de crédito concedidos em determinado período, sendo verificado através de procedimento fiscal levado a efeito pela Secretaria da Receita Federal que a certidão enviada pela Empresa não foi emitida, vez que constatou-se que a certidão $n^{\circ} 2.549 .239$ foi emitida para outro contribuinte". No voto condutor, assentou-se que "A criminalidade contemporânea, sobretudo nos delitos ditos empresariais, é caracterizada, quase sempre, por um verdadeiro 
e intrincado sistema de divisão do trabalho delituoso no qual são repartidas, entre os agentes executores da ação criminosa, uma multiplicidade de tarefas, cada qual fundamental à consecução do fim comum. As categorias tradicionais de co-autor e partícipe, assim, em vista do modelo organizacional que passou, na época moderna, a caracterizar a prática delitiva societária, não se mostram mais suficientes para a atribuição da responsabilidade penal individual. Foi assim que, a partir de uma formulação idealizada por Claus Roxin em sua monografia Täterschaft und Tatherrschaft ("Autoria e Domínio do Fato") para estabelecer a responsabilidade oriunda dos crimes cometidos pelo Estado nacional-socialista alemão, construiu-se o conceito de autor mediato, ou seja, aquele que, atuando na cúpula da associação criminosa, dirige a intenção do agente responsável pela prática direta do ato delituoso. $\mathrm{O}$ autor mediato não tem, propriamente, o domínio do fato, mas sim o domínio da organização, que, segundo o vaticínio de Jorge de Figueiredo Dias, "constituye una forma de dominio-de-la-voluntad que, indiferente a la actitud subjetivopsicológica del específico ejecutor, no se confunde con el dominio-del error o con el dominio-de-la-coacción, integrando un fundamento autónomo de la autoría mediata" (Autoría y Participación en el Dominio de la Criminalidad Organizada: el "Dominio de la Organización". In OLIVÉ, Juan Carlos Ferré e BORRALLO, Enrique Anarte. Delincuencia organizada - Aspectos penales, procesales y criminológicos. Huelva: Universidad de Huelva, 1999). "En la discusión que ha sucedido a la construcción científica de la autoría mediata", pondera Carlos Gómez-Jara Diez, "(...) puede observarse cómo la piedra angular radica en el criterio que fundamenta el dominio de la organización", consignando o referido doutrinador, a respeito, que "la responsabilidad del superior jerárquico viene dada por su «dominio de la configuración relevante superior»". Salienta, sobretudo, que "esta possibilidad entra en consideración cuando el superior jerárquico sabe más sobre ma peligrosidad para los bienes juridicos que su proprio subordinado" (¿Responsabilidade penal de los directivos de empresa en virtud de su dominio de la organización? Algunas consideraciones críticas. In Revista Ibero-Americana de Ciências Penais. Porto Alegre: ESMP, 2005. n. 11, p. 13). Na espécie, o contexto probatório carreado aos autos revela, à saciedade, que atuou Marco Antônio, sim, como "agente de trás", dedicando-se a engendrar e pôr em prática, através de interpostas pessoas, a fraude que propiciou o levantamento irregular do financiamento alcançado perante o BNDES. Nesse sentido, evidenciando a 
ingerência do réu Marco sobre os fatos delituosos, observa-se que, muito embora o codenunciado Daniel tenha mencionado na acareação que desconhecia o momento em que o gestor da empresa tomou conhecimento da falsificação da CND, não se pode ignorar que este acusado também afirmou categoricamente, em sua primeira manifestação na fase policial, que o réu Marco Antônio tinha ciência da falsidade perpetrada, bem como descreveu minuciosamente o contexto fático-delitivo no qual fica evidente a pressão do réu Marco Antônio sobre a empregada Giovana (...). Conquanto a ré Giovana não tenha imputado diretamente qualquer responsabilidade ao seu ex-patrão pelo crime ocorrido em 05/07/1999, entendo que a sua permanência na empresa até 31/03/2001 (fl. 121 e 125), aliada à declaração de Marco Antônio perante o juízo a quo (fl. 24) no sentido de que "tinham pressa em liberar o dinheiro para a conclusão da obra de ampliação do prédio; que em decorrência da pressa cobrava da Sra. Giovana a documentação necessária à liberação da parcela do financiamento", não deixa dúvida alguma de que o gestor da empresa - ainda que não tenha atuado diretamente na falsificação da CND - tinha ciência da existência de obstáculo à obtenção do documento imprescindível à liberação do financiamento, bem como acabou concordando com os termos do documento ansiosamente aguardado.

Análise crítica do Caso 4. Pelo que se extrai da denúncia ofertada pelo Ministério Público, Daniel e Giovana são autores imediatos do crime estampado no artigo 19 da Lei n. ${ }^{o}$ 7.492/1986, pois eles falsificaram uma certidão de quitação de tributos e contribuições federais administrados, posteriormente encaminhada por Giovana ao Banco Regional de Desenvolvimento do Extremo Sul. Partindo do princípio que Marco Antônio determinou a Giovana a realização da falsificação - a decisão não revela claramente se houve ou não ordem nesse sentido - remanescem duas situações: ou ele será considerado indutor da conduta criminosa ou, se demonstrada coação, será considerado autor mediato. Pela leitura do decisum, contudo, tem-se a impressão de que a primeira hipótese é a mais verossímil. Seja como for, novamente utilização da teoria do domínio de vontade por aparatos organizados de poder se revelou equivocada. Em outro dizer: asseverar, como fez o Tribunal Regional Federal da $3^{\text {a }}$ Região, que "o contexto probatório carreado aos autos revela, à saciedade, que atuou Marco Antônio, sim, como 'agente de trás', dedicando-se a engendrar e pôr em prática, através de interpostas pessoas, a fraude que propiciou o 
levantamento irregular do financiamento alcançado perante o BNDES" não tem sentido quando inexistente - ou pelo menos não demonstrada faticamente - uma estrutura ordenada hierarquicamente com divisão de tarefas e executores fungíveis. 


\section{SOLUÇÃO DOS CASOS PROPOSTOS}

Expostas as premissas adotadas, é chegada a hora de concluirmos a nossa análise, o que sucederá mediante a apresentação de soluções aos casos deduzidos no decorrer do presente trabalho.

\section{Caso ${ }^{o} 1$ (inspirado em julgado do Tribunal Regional Federal da $2^{a}$} Região). Resolução do caso: os cinco membros do Conselho de Administração ostentam deveres especiais relacionados ao bem jurídico protegido pelo crime de gestão temerária de instituição financeira (crime próprio). Ao votarem favoravelmente à realização do ruinoso empréstimo, quebraram esse dever e, além disso, geraram risco desaprovado ao bem jurídico tutelado, devendo responder penalmente como coautores do crime definido no artigo $4^{\circ}, \S$ único, da Lei n. ${ }^{\circ}$ 7.492/1986. A nosso ver, não se pode imputar responsabilidade penal aos dois Conselheiros dissidentes, pois eles não proporcionaram risco juridicamente desaprovado ao bem jurídico. Não obstante, destaque-se o entendimento contrário de Elena Marín de Espinosa Ceballos, no sentido de que o membro do Conselho de Administração de uma Companhia exerce função de garante e, nessa condição, conquanto tenha votado contra a operação na reunião do órgão colegiado, ele tem o dever de impugnar a realização do empréstimo, sob pena de ser implicado como autor do crime de gestão temerária de instituição financeira na modalidade comissiva por omissão ${ }^{635}$. O gerente “ $\underline{P}$ ”, a seu turno, não detém o dever específico e não se enquadra no rol do artigo 25 da Lei n. ${ }^{\circ}$ 7.492/1986, na medida em que não administrada a instituição financeira como um todo. Como ele obedeceu à ordem emanada do Conselho de Administração da instituição financeira ' $\underline{X Y Z}$ ' e cooperou dolosamente na execução do crime, será penalmente responsável na condição de cúmplice.

Caso 2 (inspirado na imputação penal formulada nos autos da ação penal n. ${ }^{o}$ 2007.61.81.008823-6, em trâmite perante a $8^{a}$ Vara Criminal Federal de São Paulo).

\footnotetext{
${ }^{635}$ MARÍN DE ESPINOSA CEBALLOS, Elena B. Criminalidad de empresa: la responsabilidad penal en las estructuras jerárquicamente organizadas, cit., p. 202 e ss.
} 
Resolução do caso: " $\underline{M A C}$ ” exerce a função de Diretor de Segurança de voo da " $\underline{T}$ ” Linhas Aéreas S/A (Safety) assumindo, assim, a condição de garante no contexto da organização empresarial na forma do artigo $13, \S 2^{\circ}$, alínea $b$, do Código Penal, valendo ressaltar que o crime de perigo decorreu estritamente das atividades da sociedade empresária. " $M A C$ ", portanto, será autor do crime previsto no artigo 261 do Código Penal na modalidade dolosa (eventual) pois mesmo ciente das péssimas condições da pista do aeroporto deixou de cumprir seu dever de garante e proteger o bem jurídico protegido (incolumidade pública).

Caso 3 (sociedade empresária que nasce lícita, mas posteriormente passa a cometer sistematicamente crimes contra o sistema financeiro nacional). Resolução do caso: a sociedade empresária denominada " $\underline{P C C}$ " pode ser equiparada a uma organização criminosa porque seus membros cometeram crimes contra o sistema financeiro nacional sistematicamente atendendo às ordens de " $\underline{\text { }}$ " a partir do ano de 2010, desvirtuando completamente o objeto social e necessariamente lícito da sociedade empresária. No caso concreto estão presentes os requisitos exigidos pelo artigo $1^{\circ}, \S 1^{\circ}$, da Lei n. $.^{\circ} 12.850 / 2013$, ou seja, a associação de mais de 4 (quatro) pessoas estruturalmente ordenada e caracterizada pela divisão de tarefas, com objetivo de obter diretamente vantagem econômica, mediante a prática de infrações penais cujas penas máximas são superiores a 4 (quatro) anos. A partir do ano de 2010, a DTVM " $\underline{P C C}$ " equiparou-se a uma organização criminosa, dando azo, a nosso ver, à incidência da teoria da autoria mediata por intermédio de aparatos organizados de poder. Sob esse contexto, " $\underline{X}$ ” será considerado autor mediato dos crimes perpetrados por seus funcionários, os quais, a seu turno, serão imputados na condição de autores imediatos (executores).

Caso 4 (crime contra as relações de consumo praticado no contexto de organização empresarial). Resolução do caso: “ $\underline{A}$ ”, “ $\underline{B}$ ”, “ $\underline{C}$ ” $e$ “ $\underline{D}$ ” são penalmente responsáveis pelo crime contra as relações de consumo na condição de coautores. A conduta é flagrantemente dolosa, pois existiam diversos estudos técnicos indicando que a substância " $\underline{T}$ ” era potencialmente prejudicial à saúde dos consumidores. Na hipótese não existem elementos para a caracterização de um aparato organizado de poder. " $\underline{ }$ " e " $\underline{Z}$ " determinaram que os funcionários " $\underline{M}$ " e “ $O \underline{ }$ ” executassem a conduta, mas não decidiram pela prática da conduta, podendo ser enquadrados como instigadores e, nesse caso, “ $\underline{M}$ ” e 
“ $O$ " serão autores imediatos. Entretanto, pode-se cogitar eventualmente da autoria mediata de " $\underline{X}$ " e " $\underline{Z}$ " em virtude do domínio da vontade de " $\underline{M}$ " e " $\underline{O}$ ” se ficar caracterizada hipótese de erro destes.

Caso 5 (crime contra o meio ambiente). Resolução do caso: “ $\underline{X}$ ” praticou o crime do artigo 54 da Lei n. ${ }^{0}$ 9.605/1998 na condição de autor imediato. Embora suspeitasse que a substância fosse tóxica, continuou a realizar a conduta, assumindo o risco de produzir o resultado (morte dos animais), agindo, assim, com dolo eventual. O gerente " $\underline{Y}$ ” ordenou que " $\underline{X}$ ” realizasse o comportamento criminoso, incutindo em sua cabeça o desiderato criminoso. " $\underline{Y}$ ", portanto, será partícipe por instigação, visto que não realizou qualquer ato de execução do delito ambiental, embora intuitivamente se possa afirmar que a intervenção de " $\underline{Y}$ " na concretização do evento criminoso foi bem mais acentuada do que a de " $\underline{X}$ ". 


\section{CONCLUSÕES}

Da presente dissertação podem ser extraídas as seguintes conclusões.

1. A organização empresarial moderna representa uma realidade social emergente cuja estrutura hierárquica no plano vertical e a divisão de funções no plano horizontal dificulta sobremaneira a imputação penal do indivíduo pelos crimes perpetrados.

2. A imputação do resultado criminoso a um sujeito não se esgota na relação de causalidade naturalística, devendo-se lançar mão de critérios normativos retirados da teoria da imputação objetiva (criação de risco desaprovado e verificação desse risco no resultado).

3. No âmbito do Direito Econômico, a teoria da imputação objetiva consubstancia importante instrumento de atribuição de responsabilidade ao estabelecer critérios distintivos entre uma conduta neutra e uma conduta verdadeiramente criminosa.

4. A imputação penal de condutas delituosas cometidas no âmbito das organizações empresariais mais complexas pelas pessoas físicas que a compõem não prescinde da prévia verificação da conformação organizativa da sociedade empresária, ou seja, como ela é estruturada no plano vertical (hierarquia) e no plano horizontal (divisão de funções).

5. Conquanto, em princípio, o Direito Penal brasileiro não faça distinção entre as figuras dos autores, coautores e partícipes para a atribuição da responsabilidade penal, adotando, portanto, um critério monista, unitário ou extensivo, em que cada um responde na medida de sua culpabilidade, afigura-se necessário verificar a que título cada agente interveniente no evento criminoso deve ser imputado.

6. As condutas perpetradas no seio das organizações empresariais pelos agentes que dela fazem parte podem ser tanto comissivas como omissivas. Para as segundas, dever-seá estabelecer, com precisão, se o dever de garante deriva da condição de empresário. 
7. Os diversos pontos de contato entre as organizações empresariais e as organizações criminosas constituem um fator de preocupação no âmbito do Direito Penal Econômico em razão do protagonismo que a empresa assume no contexto da economia moderna e a frequência com que o contexto corporativo tem propiciado o cometimento de delitos.

8. A associação imediata e irrefletida dos dois fenômenos organizativos (empresarial e criminoso) gera repercussões negativas tanto no Direito Penal como no Direito Processual Penal.

9. Impõe-se estabelecer um critério objetivo que permita distinguir as organizações empresariais das organizações criminosas. Nesse sentido, adotamos a ideia que existe um injusto autônomo e específico para as organizações criminosas, desde que delineada uma estrutura concretamente projetada à atividade delituosa.

10. A sociedade empresária somente encontra conformação e significado na ordem jurídica; sua utilização para o cometimento de crimes contraria seu objeto social (necessariamente lícito) e, dessa forma, subverte a função social da empresa.

11. A organização empresarial criada com o escopo de proporcionar o sistemático cometimento de crimes deve equipara-se às organizações criminosas, uma vez presentes os requisitos do artigo $1^{\circ}, \S 1^{\circ}$, da Lei n. ${ }^{\circ} 12.850 / 2013$.

12. A sociedade empresária que nasce com finalidade lícita, mas que, no curso de sua vida corporativa, desvia-se de seu objeto social, transmudando-se em aparato para a prática de infrações penais graves, também será equiparada a uma organização criminosa.

13. Em situações específicas, nas quais fique caracterizado o manifesto desvirtuamento do objeto social e a ofensa do princípio constitucional da função social da empresa pela utilização abusiva e criminosa da organização empresarial pelos membros que a compõem, poder-se-á cogitar do aparecimento de um genuíno aparato organizado de poder com as subsequentes implicações da teoria do domínio de vontade. 


\section{REFERÊNCIAS}

AMBOS, Kai. La autoría mediata por organización en la sentencia contra Fujimori: transfondos políticos y jurídicos de la sentencia contra el ex presidente peruano Alberto Fujimori. In: AMBOS, Kai; MEINI, Iván (Eds.). La autoría mediata: el caso Fujimori. Lima-Peru: Ara Editores, 2010.

El caso alemán: imputación de crímenes de los subordinados al dirigente: un estudio comparado. Bogotá: Editorial Temis, 2008.

A parte geral do direito penal internacional: bases para uma elaboração dogmática. Ed. brasileira refor. e atual. São Paulo: Ed. Revista dos Tribunais, 2008.

Principios e imputación en el derecho penal internacional. Barcelona: Atelier, 2008.

BADARÓ, Gustavo Henrique; BOTTINI, Pierpaolo Cruz. Lavagem de dinheiro: aspectos penais e processuais penais: comentários à Lei 9.613/1998, com as alterações da Lei 12.683/2012. São Paulo: Ed. Revista dos Tribunais, 2012.

BAIGÚN, David, DARÍO BERGEL, Salvador. El fraude en la administración societaria. Buenos Aires: Depalma, 1991.

BAIGÚN, David. Los delitos de peligro y la prueba del dolo. Buenos Aires-Argentina: B de F, 2007.

BALTAZAR JUNIOR, José Paulo. Crime organizado e proibição de insuficiência. Porto Alegre: Livr. do Advogado Ed., 2010.

BATISTA, Nilo. Concurso de agents: uma investigação sobre os problemas da autoria e da participação no direito penal brasileiro. 4. ed. Rio de Janeiro: Lumen Juris, 2008.

BECK, Ulrich. La sociedad del riesgo: hacia una nueva modernidad. Barcelona: Ediciones Paidós, 2008.

BITENCOURT, Cezar Roberto. Tratado de direito penal. 6. ed. São Paulo: Saraiva, 2012. v. 4.

Tratado de direito penal: parte especial, dos crimes contra a administração pública e dos crimes praticados por prefeitos. 6. ed. São Paulo: Saraiva, 2012. v. 5. 
BITENCOURT, Cezar Roberto. Tratado de direito penal: parte geral. 17. ed. São Paulo: Saraiva, 2012. v. 1.

BLANCO CORDERO, Isidoro. El delito de blanqueo de capitales. 2. ed. Navarra: Editorial Aranzadi, 2002. . El delito de blanqueo de capitales. 3. ed. Navarra: Editorial Aranzadi, 2012.

BOLEA BARDON, Carolina. Autoría mediata en derecho penal. Valencia: Tirant lo Blanch, 2000.

BOTTINI, Pierpaolo Cruz. Crimes de perigo abstrato. 2. ed. São Paulo: Ed. Revista dos Tribunais, 2010.

BRUNO, Aníbal. Direito penal: parte geral. 5. ed. Rio de Janeiro: Forense, 2005. t. 1 e t. 2. BURGUÑO DUARTE, Luz Berthila. Injusto colectivo con especial referencia a la responsabilidad penal por organización. México: Universidad Nacional Autónoma de México, 2009.

CAMARGO, Antonio Luís Chaves de. Imputação objetiva e direito penal brasileiro. 1. ed. 2. tir. São Paulo: Cultural Paulista, 2002.

CANCIO MELIÁ. El injusto de los delitos de organización: peligro y significado. Política criminal en vanguardia, inmigración clandestina, terrorismo, criminalidad organizada. Navarra: Editorial Aranzadi, 2008.

; SILVA SÁNCHEZ, Jesús María. Delitos de organización. Buenos Aires: Editorial B de F, 2008.

CARO CORIA, Dino Carlos. Sobre la punición del ex presidente Alberto Fujimori. In: AMBOS, Kai; MEINI, Iván (Eds.). La autoría mediata: el caso Fujimori. Lima-Peru: Ara Editores, 2010.

CASTELLS, Manuel. A era da informação: economia, sociedade e cultura. 5. ed. São Paulo: Paz e Terra, 2009. v. 3.

A sociedade em rede: a era da informação: economia, sociedade e cultura. Tradução de Roneide Venancio Majer. 6. ed. São Paulo: Paz e Terra, 2009. v. 1.

CATANZARO, Raimondo. El delito como empresa: história social de la máfia. Madrid: Taurus Humanidades, 1992. 
COMPARATO, Fábio Konder. O poder de controle na sociedade anônima. 3. ed. Rio de Janeiro: Forense, 1983.

COSTA, José de Faria. A criminalidade em um mundo globalizado: ou plaidoyer por um direito penal não-securitário. In: INSTITUTO DE DIREITO PENAL ECONÓMICO E EUROPEU. Direito penal económico e europeu: textos doutrinários. Coimbra: Coimbra Ed., 2009. v. 3.

O fenómeno da globalização e o Direito Penal Económico. In: INSTITUTO DE DIREITO PENAL ECONÓMICO E EUROPEU. Direito penal económico e europeu: textos doutrinários. Coimbra: Coimbra Ed., 2009. v. 3.

COSTA JR., Paulo José da. Curso de direito penal. 9. ed. São Paulo: Saraiva, 2008.

CRESPO, Eduardo Demetrio. Responsabilidad penal por omisión del empresario. Madrid: Iustel, 2009.

DAVIN, João. A criminalidade organizada transnacional: a cooperação judiciária e policial na UE. 2. ed. rev. e aum. Coimbra: Almedina, 2007.

DIAS, Jorge de Figueiredo. Direito penal: parte geral: questões fundamentais: a doutrina geral do crime. 1. ed. bras., 2. ed. port. São Paulo: Ed. Revista dos Tribunais; Coimbra Ed., 2007. t. 1.

DIAS, Reinaldo. Sociologia das organizações. São Paulo: Atlas, 2008.

EIZIRIK, Nelson. A Lei das S/A comentada: arts. 121 a 188. São Paulo: Quartier Latin, 2011. v. 2.

ESTELLITA, Heloisa Criminalidade de empresa, quadrilha, e organização criminosa. Porto Alegre: Livr. do Advogado Ed., 2009.

; GRECO, Luís. Empresa, quadrilha (art. 288 do CP) e organização criminosa, uma sob a luz do bem jurídico tutelado. Revista Brasileira de Ciências Criminais, São Paulo, ano 19, v. 91, jul./ago. 2011.

FARALDO CABANA, Patricia. Responsabilidad penal del dirigente en estructuras jerárquicas: la autoría mediata con aparatos organizados de poder. Valencia: Tirant lo Blanch, 2004. (Monografías, n. 302).

FARIA, José Eduardo. O direito na economia globalizada. 1. ed. 4. tir. São Paulo: Malheiros Ed., 2004. 
FEIJOO SÁNCHEZ, Bernardo. Cuestiones actuales de derecho penal económico. Buenos Aires-Argentina: Editorial B de F, 2009.

. Derecho penal de la empresa e imputación objetiva. Madrid: Reus, 2007.

FERNANDES, Antonio Scarance. Crime organizado: aspectos processuais. São Paulo: Ed. Revista dos Tribunais, 2009.

FERNÁNDEZ IBÁÑEZ, Eva. La autoría mediata en aparatos organizados de poder. Granada: Editorial Comares, 2006.

FERRAZ, Esther de Figueiredo. A co-delinquência no direito penal brasileiro. São Paulo: Bushatsky, 1976.

FERRÉ OLIVÉ, Juan Carlos; ÁNGEL NÚÑEZ PAZ, Miguel; OLIVEIRA, William Terra de; BRITO, Alexis Couto de. Direito penal brasileiro: parte geral, princípios fundamentais e sistema. São Paulo: Ed. Revista dos Tribunais, 2011.

FERRO, Ana Luíza Almeida. Crime organizado e organizações criminosas mundiais. Curitiba: Juruá, 2009.

FIANDACA, Giovanni; MUSCO, Enzo. Derecho penal: parte general. Bogotá: Editorial Temis, 2006.

FRAGOSO, Heleno Cláudio. Conduta punível. São Paulo: José Bushatsky Editor, 1961. Lições de direito penal: a nova parte penal. 11. ed. Rio de Janeiro: Forense, 1987.

_Lições de direito penal: parte especial. São Paulo: José Bushatsky, 1959. v. 3.

_. Terrorismo e criminalidade política. Rio de Janeiro: Forense, 1981.

FRANCO, Alberto Silva. Globalização e criminalidade dos poderosos. In: PODVAL, Roberto (Org.). Temas de direito penal economico. São Paulo: Ed. Revista dos Tribunais, 2000. p. 235-256.

GARCÍA CAVERO, Percy. Derecho penal económico: parte general. 2. ed. Lima: Ed. Jurídica Grijley, 2007. t. 1.

GIL GIL, Alicia. El caso español. Imputación de crímenes de los subordinados al dirigente: un estudio comparado. Bogotá: Editorial Temis, 2008.

GODOY, Luiz Roberto Ungaretti de. Crime organizado e seu tratamento jurídico penal. Rio de Janeiro: Elsevier, 2011. 
GRECO, Luís. Cumplicidade através de ações neutras: a imputação objetiva na participação. Rio de Janeiro: Renovar, 2004.

Introdução. In: ROXIN, Claus. Funcionalismo e imputação objetiva no direito penal. Tradução e introdução de Luís Greco. 3. ed. Rio de Janeiro: Renovar, 2002.

Um panorama da teoria da imputação objetiva. 2. ed. Rio de Janeiro: Lumen Júris, 2007.

. Um panorama da teoria da imputação objetiva. 3. ed. São Paulo: Ed. Revista dos Tribunais, 2013.

; LEITE, Alaor. O que é e o que não é a teoria do domínio do fato sobre a distinção entre autor e partícipe no Direito Penal. Revista dos Tribunais, São Paulo, v. 933, jul. 2013.

GRECO, Rogério. Curso de direito penal: parte geral. 6. ed. Rio de Janeiro: Impetus, 2006. v. 1.

GRECO FILHO, Vicente. Comentários à lei de organização criminosa: Lei n. ${ }^{\circ}$ 12.850/13, São Paulo: Saraiva, 2014.

. Considerações processuais da lei de julgamento de crimes envolvendo organização criminosa. Boletim do Instituto Brasileiro de Ciências Criminais, São Paulo, ano 20, n. 239, out. 2012.

; RASSI, João Daniel. Lei de drogas anotada: Lei n. 11.343/2006. 2. ed. São Paulo: Saraiva, 2008.

GUZMÁN, José Luis. El caso chileno: imputación de crímenes de los subordinados al dirigente: un estudio comparado. Bogotá: Editorial Temis, 2008.

HASSEMER, Winfried. Direito penal libertário. Belo Horizonte: Del Rey, 2007.

- Persona, mundo y responsabilidad: bases para una teoría de la imputación en derecho penal. Bogotá: Editorial Temis, 1999.

HEFENDEHL, Roland (Ed.). La teoría del bien jurídico, ¿Fundamento de legitimación del derecho penal o juego de abalorios dogmático? Trad. Rafael Alcácer Girao. Madrid: Marcial Pons, Ediciones Jurídicas y Sociales S.A., 2007.

HERZBERG, Rolf D. La Sentencia-Fujimori: sobre la intervención del superior en los crímenes de su aparato de poder. In: AMBOS, Kai; MEINI, Iván (Eds.). La autoría mediata: el caso Fujimori. Lima-Peru: Ara Editores, 2010. 
HRUSCHKA, Joachim. Imputación y derecho penal: estudios sobre la teoría de la imputación. Navarra-España: Editorial Aranzadi, 2005.

HUNGRIA, Nélson. Comentários ao Código Penal. Rio de Janeiro: Forense, 1958. v. 1, t. 2.

. Comentários ao Código Penal. Rio de Janeiro: Forense, 1959. v. 9.

ILHARRESCONDO, Jorge Marcelo. Delitos societarios. 1. ed. Buenos Aires: La Ley, 2008 .

JAKOBS, Günther. A imputação objetiva no direito penal. Tradução André Luís Callegari. 2. ed. São Paulo: Ed. Revista dos Tribunais, 2007.

La imputación objetiva en derecho penal. Tradução Manuel Cancio Meliá. 1. ed. Buenos Aires: Ad-Hoc, 2005.

¿Qué protege el derecho penal: bienes jurídicos o la vigencia de la norma? Mendoza-Argentina: Ediciones Jurídicas Cuyo, 2004.

. Sobre la autoría del acusado Alberto Fujimori Fujimori. In: AMBOS, Kai; MEINI, Iván (Eds.). La autoría mediata: el caso Fujimori. Lima-Peru: Ara Editores, 2010.

Tratado de direito penal: teoria do injusto penal e culpabilidade. Belo Horizonte: Del Rey, 2008.

JESCHECK, Hans-Henrich; WEIGEND, Thomas. Tratado de derecho penal: parte general. 5. ed. Granada: Comares, 2002.

JORGE, Guillermo. Recuperación de activos de la corrupción. 1. ed. Ciudad Autónoma de Buenos Aires: Del Puerto, 2008.

LAMPE, Joachim. Injusto del sistema y sistemas de injusto: modelos de autorresponsabilidad penal empresarial, propuestas globales contemporáneas. Bogotá: Universidad Externado de Colombia, 2008.

LEITE, Alaor. Dúvida e erro sobre a proibição no direito penal: a atuação nos limites entre o permitido e o proibido. São Paulo: Atlas, 2013.

LEMOS JUNIOR, Arthur Pinto de. Crime organizado: uma visão dogmática do concurso de pessoas. Porto Alegre: Verbo Jurídico, 2012. 
LINARES ESTRELLA, Ángel. Un problema de la parte general del derecho penal económico: el actuar en nombre de otro, análisis del derecho penal español y cubano. Granada: Editorial Comares, 2002.

LUNA, Everardo da Cunha. Estrutura jurídica do crime. 4. ed. São Paulo: Saraiva, 1993.

MACHADO, Maíra Rocha. Internacionalização do direito penal: a gestão de problemas internacionais por meio do crime e da pena. São Paulo: Editora 34, 2004. (Coleção Direito GV).

MAIA, Rodolfo Tigre. O Estado desorganizado contra o crime organizado: anotações à lei federal n. ${ }^{\circ}$ 9.034/95 (organizações criminosas). Rio de Janeiro: Lumen Juris, 1997.

. Lavagem de dinheiro (lavagem de ativos provenientes de crime): anotações às disposições criminais da Lei n. 9.613/98. 1. ed., 2.tir. São Paulo: Malheiros Ed., 2009.

MALARINO, Ezequiel. El caso argentino: imputación de crímenes de los subordinados al dirigente: un estudio comparado. Bogotá: Editorial Temis, 2008.

MARÍN DE ESPINOSA CEBALLOS, Elena B. Criminalidad de empresa: la responsabilidad penal en las estructuras jerárquicamente organizadas. Valencia: Tirant lo Blanch, 2002. (Monografías, n. 256).

MARTÍNEZ-BUJÁN PÉREZ, Carlos. Derecho penal económico y de la empresa: parte general. 2. ed. Valencia: Tirant lo Blanch, 2007.

MEINI, Iván. El dominio de la organización en derecho penal. Lima-Perú: Palestra Editores, 2008.

. El dominio de la organización de Fujimori. Comentarios a la sentencia de 7 de abril de 2009 (Exp. A.V. 19-2001). In: AMBOS, Kai; MEINI, Iván (Eds.). La autoría mediata: el caso Fujimori. Lima-Peru: Ara Editores, 2010.

- Responsabilidad penal del empresario por los hechos cometidos por sus subordinados. Valencia: Tirant lo Blanch, 2003.

MINGARDI, Guaracy. O Estado e o crime organizado. São Paulo: IBBCRIM, 1998.

MONTANER FERNÁNDEZ, Raquel. Gestión empresarial y atribución de responsabilidad penal: a propósito de la gestión medioambiental. Barcelona: Atelier, 2008.

MORO, Sergio Fernando. Crime de lavagem de dinheiro. São Paulo: Saraiva, 2010. 
MUÑOZ CONDE, Francisco. Problemas de autoría y participación en el derecho penal económico, o ¿cómo imputar a título de autores a las personas que sin realizar acciones ejecutivas, deciden la realización de un delito en el ámbito de la delincuencia económica empresarial? Revista Penal, Salamanca, n. 9, p. 59-98, ene. 2002.

. Teoria geral do delito. Tradução e notas por Juarez Tavares e Luis Regis Prado. Porto Alegre: Sergio Antonio Fabris Editor, 1988.

MÜSSIG, Bernd. Desmaterialización del bien jurídico y de la política criminal: sobre las perspectivas y los fundamentos de una teoría del bien jurídico crítica hacia el sistema. Traduccion de Manuel Cancio Meliá e Enrique Peñaranda Ramos. Bogotá, Colombia: Universidad Externado de Colombia, Centro de Investigación en Filosofía y Derecho, 2001.

OLIVEIRA, Ana Carolina Carlos de. Hassemer e o direito penal brasileiro: direito de intervenção, sanção penal e administrative. 1. ed. São Paulo: IBCCRIM, 2013.

PAGLIARO, Antonio; COSTA JR., Paulo José da. Dos crimes contra a administração pública. 2. ed. São Paulo: Malheiros Ed., 1999.

PARIONA ARANA, Raúl. Autoría mediata por organización: consideraciones sobre su fundamentación y aplicación. Lima-Peru: Ed. Jurídica Grijley, 2009.

PASCHOAL, Janaina Conceição. Ingerência indevida: os crimes comissivo por omissão e o controle pela punição do não fazer. Porto Alegre: Sergio Antonio Fabris, 2011.

PELLEGRINI, Angiolo; COSTA JR., Paulo José da. Criminalidade organizada. 2. ed. São Paulo: Atlas, 2008.

PEÑARANDA RAMOS, Enrique; SUÁREZ GONZÁLEZ, Carlos; CANCIO MELIÁ, Manuel. Um novo sistema do direito penal: considerações sobre a teoria de Günther Jakobs. Organização e tradução de André Luís Callegari e Nereu José Giacomolli. BarueriSP: Manole, 2003.

PITOMBO, Antônio Sérgio Altieri de Moraes. Organização criminosa, nova perspectiva do tipo legal. São Paulo: Ed. Revista dos Tribunais, 2009.

PUPPE, Ingeborg. A distinção entre dolo e culpa. Tradução, introdução e notas de Luís Greco. Barueri-SP: Manole, 2004. 
RASSI, João Daniel. A imputação das ações neutras e o dever de solidariedade no direito penal brasileiro. 2012. Tese (doutorado) - Faculdade de Direito, Universidade de São Paulo, São Paulo, 2012.

REALE JÚNIOR, Miguel. Instituições de direito penal: parte geral. 2. ed. Rio de Janeiro: Forense, 2006. v. 1.

Teoria do delito. São Paulo: Ed. Revista dos Tribunais, 1998.

REQUIÃO, Rubens. Curso de direito comercial. 22. ed. São Paulo: Saraiva, 1995. v. 1.

RODRIGUES, Anabela Miranda. Criminalidade organizada: que política criminal? In: GLOBALIZAÇÃO e direito. Coimbra: Boletim da Faculdade de Direito da Universidade de Coimbra; Coimbra Ed., 2003. (Studia Iuridica, n. 73).

A globalização do direito penal: da pirâmide à rede ou entre a unificação e a harmonização. In: INSTITUTO DE DIREITO PENAL ECONÓMICO E EUROPEU. Direito penal económico e europeu: textos doutrinários. Coimbra: Coimbra Ed., 2009. v. 3.

ROSSETTI, José Paschoal; ANDRADE, Adriana. Governança corporativa: fundamentos, desenvolvimento e tendências. 6. ed. São Paulo: Atlas, 2012.

ROTSCH, Thomas. De Eichmann hasta Fujimori. In: AMBOS, Kai; MEINI, Iván (Eds.). La autoría mediata: el caso Fujimori. Lima-Peru: Ara Editores, 2010.

ROXIN, Claus. Apuntes sobre la Sentencia-Fujimori de la Corte Suprema del Perú. In: AMBOS, Kai; MEINI, Iván (Eds.). La autoría mediata: el caso Fujimori. Lima-Peru: Ara Editores, 2010. . Autoría y dominio del hecho en derecho penal. 7. ed. Madrid: Marcial Pons, 2000.

- Autoria mediata por meio de domínio de organização. In: GRECO, Luís; LOBATO, Danilo (Coords.). Temas de direito penal: parte geral. Rio de Janeiro: Renovar, 2008.

Derecho penal: parte general: fundamentos. La estructura de la teoría del delito. Madrid: Civitas, 2008. t. 1.

Estudos de direito penal. Tradução de Luís Greco. Rio de Janeiro: Renovar, 2006. Funcionalismo e imputação objetiva no direito penal. Tradução e introdução de Luís Greco. 3. ed. Rio de Janeiro: Renovar, 2002. 
ROXIN, Claus. A proteção de bens jurídicos como função do direito penal. Org. e trad. André Luís Callegari, Nereu José Giacomolli. Porto Alegre: Livr. do Advogado Ed., 2006.

Reflexões sobre a problemática na imputação em direito penal. In:

Problemas fundamentais de direito penal. Trad. Ana Paula dos Santos Luis Natscherad. 3. ed. Lisboa: Vega, 2004.

RUDOLPHI, Hans-Joachim. Causalidad e imputación objetiva. Colombia: Universidad Externado de Colombia, 2006.

SALVADOR NETTO, Alamiro Velludo. Tipicidade penal e sociedade de risco. São Paulo: Quartier Latin, 2006.

SANTOS, Cláudia Maria Cruz. O crime de colarinho branco: da origem do conceito e sua relevância criminológica à questão da desigualdade na administração da justiça penal. Coimbra: Boletim da Faculdade de Direito da Universidade de Coimbra; Coimbra Ed., 2001. (Studia Iuridica, n. 56).

SANTOS, Juarez Cirino dos. Direito penal: parte geral. 4. ed. rev. e ampl. Florianópolis: Conceito Editorial, 2010.

SCHROEDER, Friedrich-Christian. Disposición al hecho versus fungibilidad. In: AMBOS, Kai; MEINI, Iván (Eds.). La autoría mediata: el caso Fujimori. Lima-Peru: Ara Editores, 2010.

SCHÜNEMANN, Bernd. Consideraciones sobre la teoría de la imputación objetiva. In: Obras. 1. ed. Santa Fe: Rubinzal-Culzoni, 2009. (Colección Autores de Derecho Penal, t. 1).

Las prescripciones sobre la autoría en la ley boliviana sobre la base de las modificaciones al código penal del 10 de marzo de 1997 y sus consecuencias para la responsabilidad de los órganos de las empresas: ¿un modelo para latinoamérica? In: Obras. 1. ed. Santa Fe: Rubinzal-Culzoni, 2009. (Colección Autores de Derecho Penal, t. 2.

Sobre la regulación de los delitos de omisión impropia en los eurodelitos. TIEDEMANN, Klaus (Dir.); NIETO MARTÍN, Adán (Coord.). Eurodelitos: el derecho penal económico en la Unión Europea. Cuenca: Ediciones de la Universidad de Castilla-La Mancha, 2004.

El tempestuoso desarrollo de la figura de la autoría mediata. In: Obras. 1. ed. Santa Fe: Rubinzal-Culzoni, 2009. (Colección Autores de Derecho Penal, t. 1). 
SHECAIRA, Sérgio Salomão. Responsabilidade penal da pessoa jurídica. 3.ed. Rio de Janeiro: Elsevier, 2011.

SILVA, José Afonso da. Comentário contextual à Constituição. São Paulo: Malheiros Ed., 2005.

. Curso de direito constitucional positivo. 16. ed. São Paulo: Malheiros Ed., 1999.

SILVA JÚNIOR, José et. al. Código Penal e sua interpretação jurisprudencial: parte especial. 6. ed. São Paulo: Ed. Revista dos Tribunais, 1997. v.1, t. 2.

SILVA SÁNCHEZ, Jesús María. La expansión del derecho penal: aspectos de la política criminal en las sociedades postindustriales. 2. ed. Buenos Aires: B de F, 2008.

SILVA SÁNCHEZ, Jesús María. Responsabilidad penal de las empresas y de sus órganos en derecho español. Responsabilidade penal da pessoa jurídica: em defesa do princípio da imputação penal subjetiva. 2. ed. São Paulo: Ed. Revista dos Tribunais, 2010.

SIQUEIRA, Galdino. Tratado de direito penal: parte especial. 2. ed. Rio de Janeiro: José Konfino, 1951. t. 2, v. 4.

SOUZA, Artur de Brito Gueiros. Teoria do domínio do fato e sua aplicação na criminalidade empresarial: aspectos teóricos e práticos. Revista Brasileira de Ciências Criminais, São Paulo, ano 21, n. 105, nov./dez. 2013.

SOUZA, Fátima. PCC: a facção. Rio de Janeiro: Record, 2007.

SPAGNOLO, Giuseppe. L’associazione di tipo mafioso. 5. ed. agg. Padova: Cedam, 1997.

SZTAJN, Rachel. Comentários à Lei de Recuperação de Empresas e Falência: Lei 11.101/2005, artigo por artigo. Coordenação Francisco Satiro de Souza Junior, Antônio Sérgio A. de Moraes Pitombo. 2. ed. São Paulo: Ed. Revista dos Tribunais, 2007.

TAVARES, Juarez. Direito penal da negligência: uma contribuição à teoria do crime culposo. 2. ed. Rio de Janeiro: Lumen Juris, 2003.

TIEDEMANN, Klaus. Derecho penal económico: introducción y parte general. Perú: Editorial Grijley, 2009.

TOLEDO, Francisco de Assis. Ilicitude penal e causas de sua exclusão. Rio de Janeiro: Forense, 1984.

Princípios básicos de direito penal. 5. ed. São Paulo: Saraiva, 2000 
VILLAS BÔAS FILHO, Orlando. Teoria dos sistemas e o direito brasileiro. São Paulo: Saraiva, 2009.

ZAFFARONI, Eugenio Raúl; PIERANGELI, José Henrique. Manual de direito penal brasileiro: parte geral. 4. ed. São Paulo: Ed. Revista dos Tribunais, 2002.

ZIEGLER, Jean. Os senhores do crime: as novas máfias contra a democracia. Rio de Janeiro: Record, 2003.

ZÚÑIGA RODRÍGUEZ Laura. Bases para un modelo de imputación de responsabilidad penal a las personas jurídicas. 3. ed. Navarra: Editorial Aranzadi, 2009.

Criminalidad organizada y sistema de derecho penal: contribución a la determinación del injusto penal de organización criminal. Granada: Editorial Comares, 2009. 